\title{
Coleta seletiva com inclusão de catadores: construção participativa de indicadores e índices de sustentabilidade
}

\author{
Gina Rizpah Besen
}

Tese apresentada ao programa de Pós Graduação em Saúde Pública para obtenção do título de

Doutor em Saúde Pública.

Área de Concentração: Saúde Ambiental

Orientadora: $\operatorname{Prof}^{\mathrm{a}} \mathrm{Dr}^{\mathrm{a}}$ Helena Ribeiro

Co-Orientadora: $\operatorname{Prof}^{\mathrm{a}} \mathrm{Dr}^{\mathrm{a}}$ Wanda Maria

Risso Günther

São Paulo

2011 


\section{DEDICATÓRIA}

Dedico esta Tese, na qual trabalhei com paixão e dedicação, ao meu querido companheiro Pedro que sempre me estimula a ser uma pessoa melhor e a enfrentar novos desafios e cujo apoio foi fundamental para que eu trilhasse este caminho.

À minha querida filha Beatriz, luz da minha vida, e às futuras gerações de quem depende a continuidade da vida com qualidade no planeta.

À Magdalena Maione, minha irmã do coração por ter renascido em 2011 e continuar me inspirando a lutar pelo que acredito.

Também quero dedicá-la aos catadores de materiais recicláveis, representados pelas minhas amigas Maria, Ana, Rosana, Andréa, Jandira e Benedita, da Cooperativa de Reciclagem de Matéria Prima de EmbuCOOPERMAPE, que me autorizaram a publicar as suas fotos nesse trabalho.

Estas guerreiras muito me ensinaram sobre o que é fé, coragem e perseverança. Estas mulheres inspiradoras juntamente com milhares de outras, anônimas e não anônimas, e lideranças do Movimento Nacional dos Catadores como Roberto, Eduardo, Roberval, Madalena, Dona Geralda, Luis Henrique, Tião, Gordin, Cardoso, dentre tantos outros construíram e ainda têm pela frente o desafio de consolidar a coleta seletiva com inclusão social de catadores no Brasil. Esta é uma história de luta e de sucesso da justiça social que vem mudando as vidas de centenas ou até milhares de pessoas, que como eu, com eles convivemos e aprendemos. 

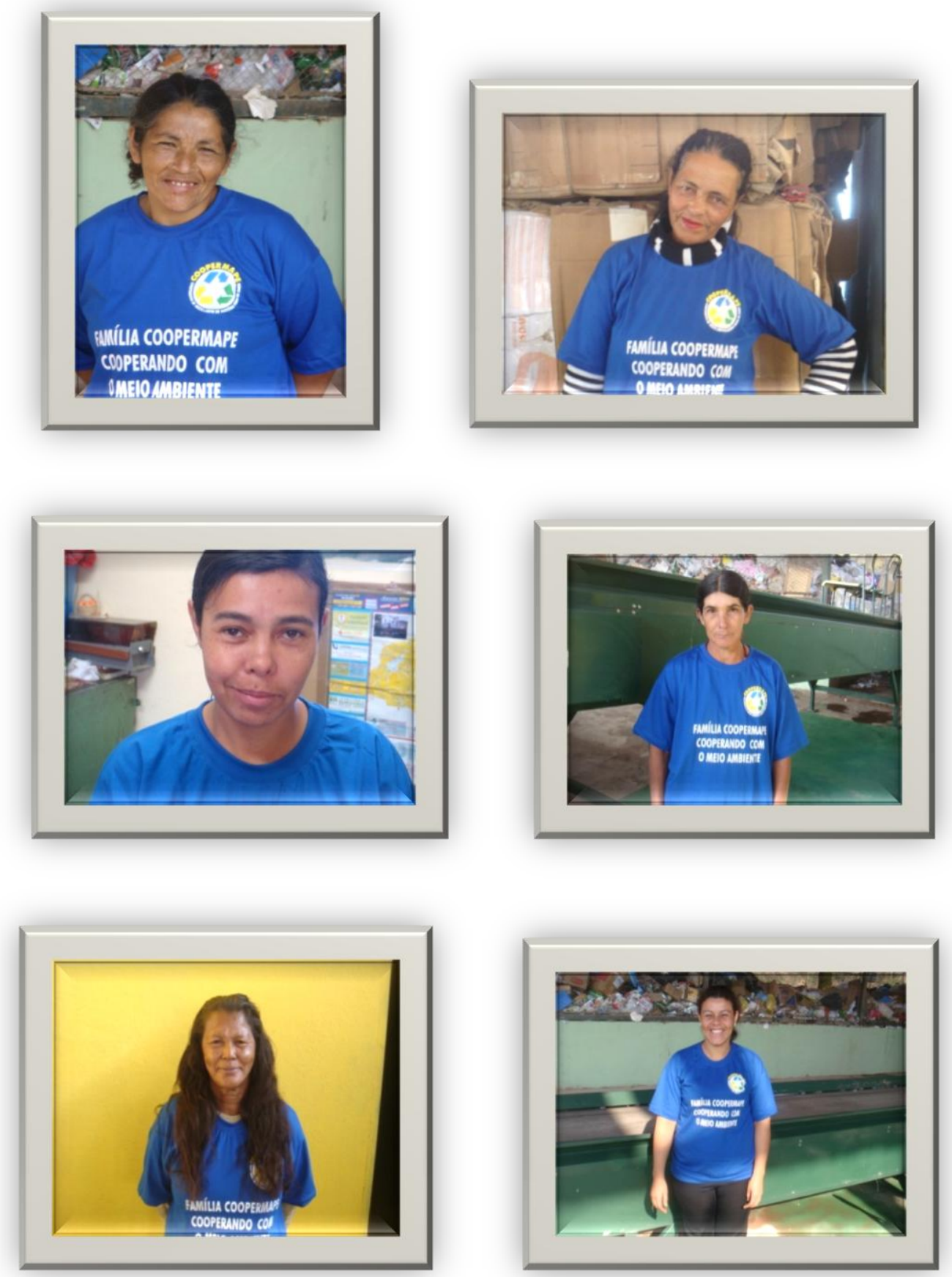

Não poderia deixar de dedicar este trabalho ao ex - presidente Luis Inácio Lula da Silva cuja visão e ação social contribuíram de forma decisiva para tornar este modelo uma realidade no Brasil e uma referência para outros países. 


\section{AGRADECIMENTOS}

À minha orientadora de mestrado e de doutorado $\operatorname{Prof}^{\mathrm{a}} \operatorname{Dr}^{\mathrm{a}}$ Helena Ribeiro por quem sinto uma grande admiração como profissional e como ser humano, pela oportunidade de amizade, aprendizado e crescimento.

À minha co-orientadora $\operatorname{Prof}^{\mathrm{a}} \mathrm{Dr}^{\mathrm{a}}$ Wanda Maria Risso pelo envolvimento dedicação e disponibilidade permanente e contribuições.

Aos Profs. Carlos Machado e Flavio Tayra pelas importantes contribuições para o direcionamento da tese no Exame de Qualificação.

Aos Profs. Evandro Mateus Moretto e Pedro Roberto Jacobi pelas discussões e sugestões.

Ao Nilson Silva Soares pelo apoio na sistematização dos dados no EPPIINFO. Ao Samuel Luna de Almeida pela elaboração dos mapas.

Ao meu querido irmão Jacques Besen pela colaboração e sugestões.

Aos especialistas que participaram da pesquisa e dedicaram parte do seu tempo na construção desse novo conhecimento.

Ao Fórum Lixo e Cidadania do Estado de São Paulo, à Fundação Centro Tecnológico de Minas Gerais - CETEC, ao Fórum Lixo e Cidadania da Cidade e do Estado de Minas Gerais, ao Fórum Lixo e Cidadania do Rio de Janeiro, ao Fórum Lixo e Cidadania do estado de Pernambuco- FLIC-PE pelas parcerias na realização nas oficinas regionais.

Aos catadores de materiais recicláveis que participaram da Oficina realizada no 8 Festival Lixo e Cidadania, pelas importantes contribuições, pelo entusiasmo que demonstraram e por me fazerem vislumbrar o quanto os indicadores podem ser úteis no desenvolvimento do seu trabalho.

Aos técnicos da Superintendência de Limpeza Urbana- SLU de Belo Horizonte e aos técnicos do Instituto Nenuca de Desenvolvimento Sustentável - INSEA pelas importantes discussões e contribuições nas oficinas.

Aos técnicos que me receberam nas visitas à coleta seletiva nas cidades e nas organizações de catadores.

À Associação de Recicladores de Bogotá na figura de Silvio Ruiz pela receptividade e coragem com que estão enfrentando os grandes desafios para consolidar a coleta seletiva com inclusão de catadores na Colômbia.

Às amigas e amigos e profissionais comprometidos com a consolidação da coleta seletiva com a luta pela inclusão de catadores; em especial à Sonia Maria Dias, amiga de todas as horas, Bertrand Alencar, e Pólita Gonçalves.

Ao CNPQ cuja bolsa e taxa de bancada permitiram a realização dessa pesquisa com a profundidade necessária, e desejo possa contribuir para a ampliação de políticas municipais de coleta seletiva com inclusão de catadores tão necessária no Brasil. 


\section{RESUMO}

BESEN, G. R. Coleta seletiva com inclusão de catadores: construção participativa de indicadores e índices de sustentabilidade [tese de doutorado]. São Paulo: Faculdade de Saúde Pública da USP; 2011.

No Brasil, em 2008, 994 municípios (18\%) praticavam a coleta seletiva, 66\% deles em parceria com catadores de materiais recicláveis, organizados em associações e cooperativas. O aumento destas iniciativas demanda avaliação quanto ao seu desempenho tanto no plano operacional quanto no socioambiental. A elaboração de indicadores e índices para avaliar e monitorar a sustentabilidade da coleta seletiva e de organizações de catadores, de forma participativa, constitui instrumentos relevantes para a consolidação da coleta seletiva e o fortalecimento das organizações de catadores. Nesse sentido, se identificou, construiu e validou indicadores de sustentabilidade para a gestão, avaliação e monitoramento com o objetivo de fortalecer sua inserção nos sistemas municipais de resíduos sólidos e sua interface com a inclusão social e a saúde pública. Realizou-se pesquisa qualitativa e quantitativa, por meio de: 1) aplicação de duas rodadas de questionários por meio eletrônico, junto a 88 especialistas no país, utilizando-se a Técnica Delphi, com retorno de 67\% na primeira rodada e $72,9 \%$ na segunda; 2 ) oficinas regionais, em quatro cidades do país envolvendo atores diversos que atuam com a temática e, 3) oficinas específicas com organizações de catadores, técnicos municipais e de organização não governamental. Os participantes validaram duas definições de sustentabilidade, uma para a coleta seletiva e uma para organizações de catadores. A partir do processo de validação e ponderação de indicadores construíram-se duas matrizes de sustentabilidade para o cálculo dos índices de sustentabilidade; uma com 14 indicadores para a coleta seletiva municipal e outra com 21 para organizações de catadores, com as respectivas formas de cálculo e tendências à sustentabilidade. Elaborou- se também dois instrumentos de comunicação (Radares da Sustentabilidade) para facilitar o entendimento por público mais amplo e direcionar o monitoramento. A meta é disseminar estes indicadores para que possam ser aplicados em políticas públicas e aperfeiçoados.

Palavras - chave: Coleta seletiva, organizações de catadores, índices e índices de sustentabilidade, política pública, gestão participativa. 
BESEN, G. R. Selective waste collection with waste pickers inclusion: participatory construction of sustainability indicators and indexes [PhD thesis]. São Paulo: School of Public Health of University of São Paulo; 2011.

\section{ABSTRACT}

In Brazil, in 2008, 994 municipalities (18\%) practiced selective waste collection, $66 \%$ of them in partnership with waste pickers organized in cooperatives and associations. The increase of municipal initiatives demands an analysis/evaluation related to its performance at the operational level as well as socio-environmental. The construction of indicators and indexes to assess the sustainability of selective waste collection and waste pickers organizations, in a participatory way, represent relevant tools for the consolidation and strengthening of selective waste collection and the organizations. This implied in the identification, development and validation, to strengthen its insertion within the municipal solid waste management system and its interface with social inclusion and public health. The research was based on quantitative and qualitative study, carried out through: 1) implementation of two rounds of questionnaires sent through electronic way to 88 experts within the country, using the Delphi Technique, with a return rate of $67 \%$ in the first round, and $72.9 \%$ in the second; 2) regional workshops in four cities involving several actors who work with the theme, and 3) workshops with waste pickers organizations, technicians of the municipal government and from a nongovernmental organization. The participants validated two definitions of sustainability, one for the selective waste collection and other for waste pickers organizations. The validation and weighting of indicators enabled the construction of two matrixes of sustainability, to calculate sustainability indexes, with 14 indicators for selective municipal waste collection and 21 for the organizations, with their respective means of calculation and sustainability trends. Two instruments of communication (Radars of Sustainability) were also developed to facilitate the understanding and monitoring by a larger public. The goal is to disseminate these indicators so that they can be implemented by public policies.

Keywords: Selective waste collection, waste pickers organizations, sustainable indicators and indexes, public policy, participatory management. 


\section{ÍNDICE}

1 INTRODUÇÃO

2 RESÍDUOS SÓLIDOS: DESENVOLVIMENTO SUSTENTÁVEL E SAÚDE PÚBLICA

3 DIFERENCIAL DA COLETA SELETIVA NO BRASIL

3.1 POLITICAS PÚBLICAS DE INCLUSÃO DE CATADORES 39

3.2 ORGANIZAÇÃO SOCIAL E POLÍTICA DOS CATADORES 44

3.2.1 Empoderamento, princípios e organização 49

3.2.2 Redes nacionais e internacionais de catadores 52

4 MARCOS CONCEITUAIS $\quad 57$

4.1 GESTÃO INTEGRADA E SUSTENTÁVEL DE RESÍDUOS SÓLIDOS

4.2 INDICADORES DE SUSTENTABILIDADE: CONSTRUÇÃO E VALIDAÇÃO PARTICIPATIVA

4.2.1 Indicadores de resíduos sólidos urbanos 71

4.2.2 Indicadores de organizações de catadores $\quad 77$

4.2.3 Indicadores de sustentabilidade de resíduos urbanos $\quad 78$

4.2.3 Indicadores de sustentabilidade de coleta seletiva 81

e de organizações de catadores

5 OBJETIVOS

88

5.1 OBJETIVO GERAL 88

5.2 OBJETIVOS ESPECÍFICOS 88

6 MÉTODOS E TÉCNICAS $\quad 89$

6.1 ESTRATÉGIAS DA PESQUISA 89 
6.2 INDICADORES DE SUSTENTABILIDADE: CONSTRUÇÃO E VALIDAÇÃO

6.2.1 $1^{\text {a }}$ Etapa: $1^{\text {a }}$ rodada Delphi e oficinas regionais 94

6.2.2 2 $2^{\text {a }}$ Etapa: $2^{\text {a }}$ rodada Delphi e oficinas específicas 100

6.2.3 3a Etapa: Elaboração de matrizes e índices 102

6.2.4 Instrumento de Comunicação 104

6.3 COLETA SELETIVA NA REGIÃO METROPOLITANA DE SÃO PAULO 105

$\begin{array}{ll}7 \text { RESULTADOS E DISCUSSÃO } & 107\end{array}$

7.1 COLETA SELETIVA NA REGIÃO METROPOLITANA DE SÃO 108

7.2 VALIDAÇÃO DE INDICADORES DE SUSTENTABILIDADE 127

7.2.1 A visão dos especialistas: técnica Delphi 128

7.2.1.1 Perfil dos especialistas $\quad 129$

7.2.1.2 Avaliação das definições de sustentabilidade $\quad 130$

7.2.1.3 1ª rodada do Delphi 133

7.2.1.4 2ª rodada do Delphi 140

7.2.2 A visão dos diversos atores em oficinas regionais 153

7.2.3 A visão de atores em oficinas específicas 164

7.2.4 A busca de convergências nas diferentes visões 172

7.3 MATRIZES E ÍNDICES DE SUSTENTABILIDADE 179

$\begin{array}{ll}\text { 7.3.1 Coleta seletiva } & 180\end{array}$

$\begin{array}{ll}\text { 7.3.2 Organizações de catadores } & 183\end{array}$

8 COMUNICAÇÃO DOS INDICADORES E INDICES 187

9 CONCLUSÕES E RECOMENDAÇÕES 192

$\begin{array}{ll}\text { REFERÊNCIAS } & 198\end{array}$ 
APÊNDICE A - Termo de Consentimento Livre e Esclarecido 217

APÊNDICE B - Questionário da 1aㅡ rodada técnica Delphi 219

APÊNDICE C - Convite da oficina regional de São Paulo 225

APÊNDICE D - Convite da oficina regional de Belo Horizonte 227

APÊNDICE E - Convite da oficina regional do Rio de Janeiro 229

APÊNDICE F - Convite da oficina regional de Recife 230

APÊNDICE G - Questionário da 2ª rodada técnica Delphi 231

APÊNDICE H - $\quad$ Proposta da oficina de indicadores - Festival 246

APÊNDICE I - $\quad$ Coleta seletiva na Região Metropolitana de 248

APÊNDICE J - Dados da coleta seletiva na RMSP, período 251 $2005-2010$

APÊNDICE K - Variação percentual de membros- organizações 252

APÊNDICE L - $\quad$ Dados das organizações de catadores na RMSP, 253 2004 e 2010

APÊNDICE M - Organizações de catadores; membros, renda 256 comercialização e produtividade, 2010

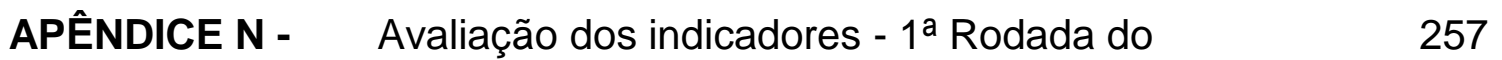
Delphi com especialistas

APÊNDICE 0 - $\quad$ Indicadores de coleta seletiva e de organizações 258 de catadores, modo de medição e tendências à sustentabilidade

Apêndice 1- Indicadores de coleta seletiva 258

Apêndice 2 - Indicadores de organizações 260 de catadores 
APÊNDICE P - Avaliação de Indicadores de sustentabilidade

por organizações de catadores, Belo Horizonte, 2009

Apêndice 1 - Avaliação de indicadores de 262 sustentabilidade de organizações de catadores

Apêndice 2 - Avaliação de indicadores de sustentabilidade da coleta seletiva

APÊNDICE Q - $\quad$ Avaliação de Indicadores de sustentabilidade por técnicos municipais da SLU, Belo Horizonte, 2009

Apêndice 1 - Avaliação de indicadores de sustentabilidade da coleta seletiva

Apêndice 2 - Avaliação de indicadores de sustentabilidade de organizações de catadores

APÊNDICE R - Avaliação de Indicadores de sustentabilidade por técnicos do INSEA, Belo Horizonte, 2010

Apêndice 1 - Avaliação de indicadores de sustentabilidade da coleta seletiva

Apêndice 2 - Avaliação de indicadores de sustentabilidade de organizações de catadores

APÊNDICE S - Renda média e quantidade de recicláveis comercializados, 2005 e 2010, e variação percentual da TRMR, número de membros, renda média dos membros em municípios da RMSP, período 2005 - 2010

APÊNDICE T - Indicadores de sustentabilidade de coleta seletiva e de organizações catadores, médias e medianas, $2^{\mathrm{a}}$ rodada do Delphi 
Apêndice 1 - Indicadores de sustentabilidade

de coleta seletiva

Apêndice 2 - Indicadores de sustentabilidade

274

de organizações de catadores

\section{ANEXOS}

ANEXO 1 - Índice da Coleta Seletiva - ICS - CETESB 
Lista de Figuras

Figura 1 - Metodologia da Pesquisa COSELIX 82

Figura 2 - Etapas da Pesquisa de Campo 93

Figura 3 - Evolução de municípios com coleta seletiva e com 116 organizações de catadores, na RMSP, 2004 e 2010

Figura 4 - Ano de inicio da coleta seletiva em 29 municípios 117 da RMSP

Figura 5 - Variação da TRMR, número de membros e média, em municípios da RMSP, período 2005 - 2010

Figura 6 - Distribuição dos especialistas por segmento de atuação

Figura 7 - Avaliação de indicadores de sustentabilidade de coleta seletiva - 1 a rodada do Delphi

Figura 8 - Avaliação de tendências à sustentabilidade da coleta seletiva - $1^{\underline{a}}$ rodada do Delphi

Figura 9 - Avaliação de indicadores de sustentabilidade de organizações de catadores - $1^{\underline{a}}$ rodada do Delphi

Figura 10 - Avaliação de tendências à sustentabilidade de indicadores de organizações de catadores 1aㅡ rodada do Delphi

Figura 11 - Fotos da oficina com organizações de catadores, Belo Horizonte, 2009

Figura 12 - Fotos da oficina com técnicos SLU, Belo Horizonte, 2009

Figura 13 - Fotos da oficina com técnicos do INSEA, 2010

Figura 14 - Radar de Sustentabilidade da Coleta Seletiva 
Figura 15 - Radar de Sustentabilidade de Organizações de Catadores

Lista de Quadros

Quadro 1 - Situação e características dos grupos associados ao MNCR

Quadro 2 - Princípios e indicadores de sustentabilidade de gestão de resíduos sólidos

Quadro 3 - Premissas de sustentabilidade para a coleta seletiva e para as organizações de catadores

Quadro 4 - Indicadores de sustentabilidade de coleta seletiva e de organizações de catadores e respectivas tendências à sustentabilidade, COSELIX, 2005

Quadro 5 - Matriz de sustentabilidade de coleta seletiva, COSELIX, 2005

Quadro 6 - Matriz de sustentabilidade de organizações de catadores, COSELIX, 2005

Quadro 7 - Vantagens e desvantagens da aplicação da técnica Delphi

Quadro 8 - Definições de sustentabilidade avaliadas por especialistas $-1^{\underline{a}}$ e $2^{\underline{a}}$ rodadas do Delphi

Quadro 9 - Indicadores de coleta seletiva, processos e dimensões da sustentabilidade abrangidas

Quadro 10 - Indicadores de organizações de catadores, processos e dimensões da sustentabilidade

Quadro 11 - Resultados de oficinas regionais, em São Paulo, Belo Horizonte Rio de Janeiro e Recife, 2007 e 2008 
Quadro 12 - Resultado da avaliação de oficina específica com organizações de catadores, Belo Horizonte, 2009

Quadro 13 - Resultado da avaliação da oficina específica com técnicos da SLU, Belo Horizonte, 2009

Quadro 14 - Resultado da avaliação da oficina específica, com técnicos do INSEA, Belo Horizonte, 2010

Quadro 15 - Avaliação das definições de sustentabilidade por 4 grupos; especialistas, organizações de catadores, técnicos da SLU e do INSEA

Quadro 16 - Avaliação de indicadores de sustentabilidade de coleta seletiva por organizações de catadores, técnicos da SLU e técnicos do INSEA

Quadro 17 - Avaliação de indicadores de sustentabilidade de organizações catadores por especialistas, organizações de catadores, técnicos da SLU e técnicos do INSEA

Quadro 18 - Indicadores de sustentabilidade propostos nas oficinas específicas

Quadro 19 - Matriz de sustentabilidade de coleta seletiva 182

Quadro 20 - Matriz de sustentabilidade de organizações de 184 catadores

Lista de Mapas

Mapa 1 - Destinação e condição da disposição final de resíduos domiciliares na RMSP, 2005

Mapa 2 - Destinação e condição da disposição final de resíduos domiciliares na RMSP, 2009

Mapa 3 - Coleta seletiva em municípios da RMSP 
Mapa 4 - Coleta seletiva em municípios da RMSP

e quantidades comercializadas, 2010

Lista de Tabelas

Tabela 1 - Emissões evitadas de gás carbônico (CO2),

materiais particulados $\left(\mathrm{PM}_{2,5}\right)$, e substâncias tóxicas (Tolueno) e cancerígenas(Benzeno) por tonelada de resíduo sólido tratado ou disposto

Tabela 2 - Coleta de resíduos domiciliares, quantidades coletadas e variação percentual, na RMSP, 2005 e 2009

Tabela 3 - Coleta de resíduos domiciliares do município de São Paulo, 2004 a 2009

Tabela 4 - Cobertura da coleta seletiva, em municípios da RMSP, 2010

Tabela 5 - Taxa de recuperação de materiais recicláveis em municípios da RMSP, 2005 e 2010

Tabela 6 - Número de membros das organizações e percentual de crescimento em municípios da RMSP, 2005 e 2010

Tabela 7 - Avaliação de definições de sustentabilidade de coleta seletiva e de organizações de catadores, por especialistas, $1^{\underline{a}}$ e $2^{\underline{a}}$ rodadas do Delphi

Tabela 8 - Seleção de indicadores de sustentabilidade de coleta seletiva - $1^{\underline{a}}$ para a $2^{\underline{a}}$ rodada do Delphi

Tabela 9 - Seleção de indicadores de sustentabilidade de organizações de catadores - 1a para a $2^{-}$rodada do Delphi

Tabela 10 - Avaliação de indicadores de sustentabilidade de coleta seletiva, respectivas fórmulas de cálculo 
e tendências à sustentabilidade $-2^{\underline{a}}$ rodada do Delphi

Tabela 11 - Avaliação de indicadores de sustentabilidade de organizações de catadores, fórmulas de cálculo e tendências à sustentabilidade - $2^{\underline{a}}$ rodada do Delphi

Tabela 12 - Avaliação de características de indicadores de sustentabilidade de coleta seletiva - $2^{\underline{a}}$ rodada do Delphi

Tabela 13 - Avaliação de características de indicadores de sustentabilidade de organizações de catadores, $2^{\underline{a}}$ rodada do Delphi

Tabela 14 - Resultados das avaliações de indicadores em oficinas específicas 
Siglas Utilizadas

ABIHPEC -

ABRELPE -

ANPPAS -

ARB -

ASPAN -

BID -

BNDES -

CEMPRE -

CENTCOOP-DF -

CETEC -

CETESB -

$\mathrm{CNPq}$ -

CO2 e -

COP -

COSELIX -

EEA -

EPI -

FBB -

FUNASA -

GAIA -

IBGE -

ICS -
Associação Brasileira da Indústria de Higiene Pessoal, Perfumaria e Cosméticos

Associação Brasileira de Empresas de Limpeza

Pública e Resíduos Especiais

Associação Nacional de Pós Graduação e Pesquisa em Ambiente e Sociedade

Associação de Recicladores de Bogotá

Associação Pernambucana Defesa da Natureza

Banco Interamericano de Desenvolvimento

Banco Nacional de Desenvolvimento Social

Compromisso Empresarial para a Reciclagem

Central de Cooperativas do Distrito Federal

Fundação Centro Tecnológico de Minas Gerais

Companhia Ambiental do Estado de São Paulo

Conselho Nacional de Desenvolvimento Científico e Tecnológico

Gás Carbônico equivalente

Conferência das Partes da Convenção do Clima

Pesquisa "Programas municipais de coleta seletiva de lixo como fator de sustentabilidade dos sistemas públicos de saneamento na região metropolitana de São Paulo

Environment European Agency

Equipamento de Proteção Individual

Fundação Banco do Brasil

Fundação Nacional de Saúde

Global Alliance for Incinerator Alternatives

Instituto Brasileiro de Geografia e Estatística

Índice da Coleta Seletiva 
IDS -

IGR -

IIRSP -

IPT-

ISWM -

MAB -

MDS -

MMA -

MNCR -

MST -

MTE -

$\mathrm{NH} 4 \mathrm{e}$ -

OAF -

OCDE -

OMS -

ONG -

ONU -

OPS -

OSCIP -

PAC -

PANGEA -

PNAD -

PNRS -
Indicadores de Desenvolvimento Sustentável Índice de Gestão de Resíduos Sólidos

Índice de Impacto dos Resíduos Sólidos na Saúde Pública

Instituto de Pesquisas Tecnológicas

Integrated and Sustainable Solid Waste Management

Movimento dos Atingidos por Barragens

Ministério do Desenvolvimento Social e Combate à Fome

Ministério do Meio Ambiente

Movimento Nacional dos Catadores de Materiais

Recicláveis

Movimento dos Sem Terra

Ministério do Trabalho e Emprego

Gás Metano equivalente

Organização de Auxílio Fraterno

Organization for Economic Co-Operation and Development

Organização Mundial da Saúde

Organização Não Governamental

Organização das Nações Unidas

Organização Pan Americana da Saúde

Organizações Sociais de Interesse Público

Programa de Aceleração do Crescimento

Centro de Estudos Socioambientais

Pesquisa Nacional por Amostra de Domicílios

Política Nacional de Resíduos Sólidos 
PNSB -

PNUMA -

PROCAM -

RAIS-

RMSP -

RSD -

RSU -

SEADE -

SEBRAE -

SLU-BH -

SMA -

SNIS -

SUS -

SWM -

TR -

TRMR -

UFBA -

UFRJ -

UNEP -

UNDESA -

UNICEF -

WIEGO -

WWF -

WBCSD -
Pesquisa Nacional de Saneamento Básico

Programa das Nações Unidas para o Meio Ambiente

Programa de Pós Graduação em Ciência Ambiental da Universidade de São Paulo

Relação Anual de Informações Sociais

Região Metropolitana de São Paulo

Resíduos Sólidos Domiciliares

Resíduos Sólidos Urbanos

Fundação Sistema Estadual de Análise de Dados

Serviço Brasileiro de Apoio às Micro e Pequenas Empresas

Superintendência de Limpeza Urbana de Belo Horizonte

Secretaria de Estado do Meio Ambiente de São Paulo

Sistema Nacional de Informação sobre Saneamento

Sistema Único de Saúde

Municipal Solid Waste Management

Taxa de rejeito

Taxa de Recuperação de Materiais Recicláveis

Universidade Federal da Bahia

Universidade Federal do Rio de Janeiro

United Nations Environment Programme

The United Nations Department of Economic and Social Affairs

Fundo das Nações Unidas para a Infância

Women in Informal Employment: Globalizing and Organizing

Fundo Mundial para a Natureza

World Business Council for Sustainable Development 


\section{INTRODUÇÃO}

A produção excessiva e diversificada de resíduos da nossa sociedade e seus impactos negativos torna a gestão sustentável dos resíduos sólidos urbanos uma questão que requer reflexões e ações em vários níveis: socioambiental, econômico e de saúde humana.

Os resíduos gerados aumentam em virtude do crescimento populacional, do acelerado processo de urbanização, das mudanças tecnológicas e da melhoria das condições socioeconômicas dos países e cidades.

Mais da metade da população mundial vive em áreas urbanas, o que representa mais de 3,5 bilhões de pessoas, que consomem $70 \%$ dos recursos naturais globais (EEA, 2010). Esse consumo exagerado torna-se responsável por quase $80 \%$ das emissões globais de $\mathrm{CO}_{2}$ (WWF, 2010). Projeções apontam que até o ano 2050 a população do planeta deverá superar 9,2 bilhões de habitantes, dos quais 6,3 bilhões viverão em espaços urbanos (WBCSD, 2010). No Brasil quase $85 \%$ da população já vive em áreas consideradas urbanas (IBGE, 2010).

A saúde humana e dos ecossistemas pode ser afetada pela produção dos resíduos em todas as suas fases, da geração à disposição final. Portanto, reduzir a geração de resíduos sólidos demanda respostas urgentes que implicam em mudanças dos padrões existentes de produção e consumo da sociedade moderna e a implantação de um gerenciamento integrado, sustentável economicamente, socialmente justo e ambientalmente eficiente.

A coleta seletiva de resíduos sólidos domiciliares e a reciclagem são atividades que contribuem com a sustentabilidade urbana e a saúde ambiental e humana. Na dimensão econômica e ambiental promovem a sustentabilidade 
por se constituírem em ações de redução do impacto nos ecossistemas e na biodiversidade, de economia no uso de recursos naturais e de insumos como água e energia, e ainda por reduzir significativamente o descarte, a disposição no solo e a queima de resíduos. Destacam-se ainda os benefícios associados ao processo produtivo, economia de matérias primas, energia e recursos naturais e a redução de emissões de gases de efeito estufa responsáveis pelo aquecimento global (ADEDIPE et al., 2005; IPEA, 2010). No que se refere à dimensão social promovem a melhoria das condições de vida, por meio da geração de empregos e renda, e de trabalho formal e informal. Com relação à saúde humana observa-se a melhoria da qualidade da limpeza urbana, a diminuição da exposição da população a riscos causados por enchentes, redução da transmissão de doenças por vetores e redução da vulnerabilidade da população com relação aos impactos do aquecimento global na saúde humana. Destacam-se dentre estes impactos as alterações na temperatura e na umidade do ar que podem contribuir com a proliferação de agentes infecciosos (ADEDIPE et al., 2005; NOBRE et al., 2010).

Esta pesquisa tem como foco a coleta seletiva formal de resíduos sólidos domiciliares e comerciais realizada nos municípios brasileiros, em especial, a operada por catadores de materiais recicláveis, organizados em associações e cooperativas. O modelo de coleta seletiva no Brasil se amplia nas duas últimas décadas, apoiado por políticas públicas afirmativas nas várias esferas de governo, destacando-se, nos últimos oito anos, o governo federal.

As projeções de pesquisas realizadas no país apontam que são coletadas entre 140.000 (SNIS, 2008) e 160.000 toneladas de resíduos sólidos urbanos (ABRELPE, 2009) diariamente. A composição os resíduos sólidos urbanos brasileiros, segundo a Associação Brasileira de Empresas de Limpeza e Resíduos Especiais (ABRELPE, 2006) é de 57,41\% de matéria orgânica, tais como sobras de alimentos, alimentos deteriorados, lixo de banheiro e papel, $16,49 \%$ de plástico, $13,16 \%$ de papel e papelão, $2,34 \%$ de vidro, $1,56 \%$ de 
material ferroso, $0,51 \%$ de alumínio, $0,46 \%$ de inertes e $8,1 \%$ de outros materiais. Portanto, cerca de $30 \%$ a $40 \%$ são materiais passíveis de reaproveitamento e reciclagem, a partir da coleta seletiva nas fontes geradoras. A matéria orgânica pode ser transformada em composto por meio da compostagem.

Na maioria das cidades brasileiras, a lógica prevalecente ainda é a coleta dos resíduos sem separação na fonte geradora. A coleta seletiva domiciliar é voluntária na maioria dos municípios, com raras exceções, e depende fundamentalmente da sensibilização e da participação dos cidadãos, empresas e instituições.

O sistema de coleta seletiva envolve um conjunto de atividades: 1) a coleta domiciliar porta a porta ou em pontos específicos de vários tipos de materiais recicláveis, gerados após o consumo, e previamente separados nas fontes geradoras, 2) a triagem e beneficiamento dos materiais recicláveis, e 3) a comercialização desses insumos para a indústria de reciclagem. Entretanto, muitas organizações de catadores já desenvolvem atividades de reciclagem com materiais oriundos da coleta seletiva.

Nos últimos 10 anos ampliou-se no país o número de municípios que prestam serviço de coleta seletiva. No Censo do ano 2000 (IBGE, 2001) foram identificados 445 municípios com coleta seletiva municipal, e cerca de 21.500 catadores trabalhavam em lixões, entretanto não foi levantado, pelo IBGE, o número de iniciativas de coleta seletiva desenvolvidas em parceria com organizações de catadores, dados estas se encontrarem ainda num estágio embrionário de implantação.

Segundo a Pesquisa Nacional de Saneamento Básico 2008 (PNSB) (IBGE, 2010b) existiam no país 994 (18\%) municípios com coleta seletiva, sendo 653 municípios (66\%) que a praticavam em parceria com catadores organizados em cooperativas e associações. Em 279 municípios, os catadores atuavam de forma independente. 
A ampliação da coleta seletiva em parceria com organizações de catadores decorre principalmente da opção feita na esfera federal quanto ao modelo de coleta seletiva do país. Verifica-se que a Política Nacional de Saneamento Básico- Lei o 11.445 de 2007 e a Política Nacional de Resíduos Sólidos (PNRS), Lei № 12.305 de 2010, priorizam a coleta seletiva formal dos municípios por meio da contratação de organizações de catadores para a prestação do serviço. Estas políticas têm como meta fortalecer as organizações de catadores e integrá-las aos sistemas municipais de gestão de resíduos sólidos, visando à geração de renda e de postos de trabalho.

Nesse sentido, segundo DIAS E ALVES (2008) apud DIAS (2009), o Governo Federal, no período entre os anos de 2003 e 2006, investiu por meio de Ministérios, Bancos e Fundações públicas, aproximadamente $\mathrm{R} \$ 70$ milhões no setor de gestão de resíduos sólidos. A previsão para o período 2007 - 2010 era da ordem de $\mathrm{R} \$ 200$ milhões em projetos e programas de inclusão social. Os autores afirmam que estes incentivos somados ao apoio de organizações não governamentais (ONGs) e agências de fomento, contribuíram para melhorar as condições de trabalho dos catadores no país, ao agregar valor aos recicláveis e ao melhorar a posição das cooperativas e associações na cadeia produtiva da reciclagem.

O Governo Federal, por meio do Comitê Interministerial e no âmbito do programa de "Geração de postos de trabalho para cooperativas e associações de catadores" estabeleceu a meta de investir $\mathrm{R} \$ 169$ milhões, em quatro anos, para a criação de 39.040 postos de trabalho para a organização, capacitação/profissionalização de cerca de 175.000 catadores, e a implantação ou ampliação de 244 unidades de reciclagem. Nesse sentido, recursos financeiros não reembolsáveis de ministérios, da Petrobrás ${ }^{1}$, de linhas de

\footnotetext{
${ }^{1}$ Entre 2003-2008 a Petrobras investiu $\mathrm{R} \$ 24$ milhões em 26 projetos para a formação de redes de comercialização de resíduos que beneficiaram cerca de 7.200 catadores de 143 organizações. Disponível em: http://www.petrobras.com.br/minisite/desenvolvimento-e cidadania/projetos/geracao-renda-oportunidade-trabalho/rede-reciclagem-residuos.
} 
crédito do Banco Nacional de Desenvolvimento Social ${ }^{2}$ (BNDES) e da Fundação Banco do Brasil ${ }^{3}$ (FBB) têm sido investidos.

Segundo o Ministério do Meio Ambiente, o governo investirá $R \$ 1,5$ bilhão do Programa de Aceleração do Crescimento 2 (PAC 2, de 2011 a 2014) em projetos de tratamento de resíduos sólidos, erradicação de lixões, implantação da coleta seletiva e de compostagem e no financiamento de cooperativas de catadores. O recurso será destinado para prefeituras, organizações de catadores e estados para a elaboração de Planos Estaduais previstos na Política Nacional de Resíduos Sólidos (PNRS).

As organizações de catadores, por meio de projetos das administrações municipais e/ou projetos próprios apresentados em editais têm obtido recursos para a aquisição de equipamentos, construção de centrais de triagem, cursos de formação e capacitação dos catadores, melhorias nas condições sanitárias e de trabalho nas centrais de triagem e fortalecimento de redes entre as organizações que possibilitem a articulação da venda coletiva e a obtenção de capacidade de negociação de melhores preços para a venda direta de materiais recicláveis para a indústria.

No entanto, apesar dos recentes avanços das políticas públicas e dos recursos investidos no setor de resíduos sólidos, 50,8\% dos 5.565 municípios brasileiros ainda destinam os resíduos a lixões (IBGE, 2010) e a coleta seletiva executada por organizações de catadores ainda não foi integrada ao sistema de limpeza urbana enquanto prestação de serviço. As administrações municipais enfrentam dificuldades técnicas e administrativas para prestar o serviço de coleta seletiva de forma universalizada e eficiente, assim como para se

\footnotetext{
${ }^{2}$ Em 2007 o BNDES iniciou o programa de Apoio a Catadores. O primeiro ciclo, concluído em 2008 , apoiou 32 cooperativas, e investiu $R \$ 21,6$ milhões. No segundo ciclo apoiou 23 projetos e investiu R\$16,9 milhões. Disponível em:

http://www.bndes.gov.br/SiteBNDES/bndes/bndes_pt/Institucional/Sala_de_Imprensa/Noticias/2 009/Social/20090504_Catadores.html.

${ }^{3} \mathrm{Em} \mathrm{2010}$, a FBB e o MTE licitaram R\$ 1.886.800,00 em serviços de fortalecimento do cooperativismo para formação para a autogestão e assessoria técnica a 1.600 catadores. Disponível em: http://www.fbb.org.br/upload/noticia/documentos/1285944288781.pdf.
} 
relacionar com as organizações de catadores, enquanto programas de inclusão social que necessitam de apoio e ao mesmo tempo, prestadoras de serviços às prefeituras. A contratação das organizações de catadores ainda não foi incorporada enquanto prática, colocando ainda a maioria destas iniciativas no âmbito de projetos de inclusão social.

O contexto de fragilidade institucional da coleta seletiva e a busca de respostas para seu fortalecimento motivou a realização da pesquisa aqui apresentada, a qual tem por objetivo identificar e construir de forma participativa, com os principais atores sociais envolvidos, indicadores e índices de sustentabilidade para a prestação de serviço de coleta seletiva pelos municípios e para as organizações de catadores. O ponto de partida da pesquisa são as premissas e definições de sustentabilidade para a coleta seletiva e para as organizações de catadores, indicadores e respectivas tendências à sustentabilidade de ambos e os índices de sustentabilidade desenvolvidos na pesquisa "Programas municipais de coleta seletiva de lixo como fator de sustentabilidade dos sistemas públicos de saneamento ambiental na Região Metropolitana de São Paulo" (COSELIX), desenvolvida nos anos de 2004 e 2005. Esta pesquisa se desenvolveu na Região Metropolitana de São Paulo, em 2004 e 2005, e foi coordenada pela Faculdade de Saúde Pública (FSP) - Departamento de Saúde Ambiental da USP e em parceria com o Programa de Pós-Graduação em Ciência Ambiental (PROCAM) /USP e o Centro Universitário SENAC - Área de Ciências Ambientais, com financiamento do Ministério da Saúde, Fundação Nacional de Saúde (FUNASA). Foram realizados estudos de caso em 11 dos 19 municípios da RMSP que possuíam a coleta seletiva em parceria com catadores organizados em associações e/ou cooperativas. A partir dos principais resultados desta pesquisa (RIBEIRO et al., 2009) apresentados a seguir, considerou-se importante realizar uma nova pesquisa de campo, junto aos 39 municípios da Região Metropolitana de São 
Paulo - RMSP com o objetivo de verificar a evolução da coleta seletiva na região.

Enquanto resultados da pesquisa COSELIX, verificou-se que o valor da Taxa de Recuperação de Materiais Recicláveis (TRMR) da coleta seletiva nos 39 municípios variou de $0,2 \%$ a $3,0 \%$, ou seja, apresentou baixa eficiência quanto aos resultados ambientais. Este índice representa a quantidade de material desviado dos aterros sanitários e lixões em relação ao total de resíduos domiciliares coletados

Apesar das organizações de catadores gerarem postos de trabalho a baixo custo, em relação aos postos de trabalho gerados no país; o número de catadores envolvidos nos programas, em 2005, era baixo em relação à quantidade de catadores autônomos existentes nos municípios (RIBEIRO et al., 2009). Isto foi confirmado em estudos posteriores na RMSP (GUTTBERLET e BAEDER, 2008; PACHECO e RIBEIRO, 2009) e em outras cidades do país como no Distrito Federal (GENTIL, 2008) e em Recife (ALENCAR, 2008).

Ainda nessa pesquisa verificou-se que as prefeituras não cobravam taxas específicas ou tarifas de coleta, tratamento e disposição de resíduos, e a renda média dos membros das organizações foi de $R \$ 362,50$ e variou de $R \$ 125,00$ a $R \$ 600,00$. Na dimensão institucional a situação caracterizava-se pela fragilidade diante das mudanças administrativas, ausência de regras claras da relação de trabalho entre as prefeituras e as organizações, e a inexistência de contratos de remuneração pelos serviços prestados. Os recursos obtidos pelas organizações de catadores eram insuficientes para gerar um capital de giro que permitisse a modernização tecnológica e o investimento na compra do material reciclável de catadores avulsos com vistas à sua integração às cooperativas.

Esses resultados possibilitaram a elaboração de um quadro situacional sobre a coleta seletiva nos municípios da RMSP, sobre as organizações de catadores parceiras, assim como a elaboração de indicadores e índices de 
sustentabilidade, tanto para as administrações municipais quanto para as organizações de catadores, visando ao seu fortalecimento. Vários artigos técnicos sobre essa pesquisa foram apresentados em congressos nacionais e internacionais (RIBEIRO et al., 2006; GÜNTHER et al., 2006; BESEN et al., 2007) e publicados em anais, revistas acadêmicas e como capítulos de livros (JACOBI e BESEN, 2006; RIBEIRO et al., 2006; Ribeiro et al., 2010). Os resultados da pesquisa consubstanciaram-se no livro "Coleta seletiva com inclusão social: cooperativismo e sustentabilidade" (RIBEIRO et al., 2009). Vários outros trabalhos e artigos acadêmicos e técnicos sobre o tema, ao longo dos últimos anos, (ABREU, 2001; CONCEIÇÃO, 2003; MARTINS, 2004; MUNHOZ, 2004; DEMAJOROVIC et al., 2006; BESEN, 2006; DIAS, 2006; VIVEIROS, 2006; GÜNTHER e GRIMBERG, 2006; GRIMBERG, 2007; MNCR, 2007; RIBEIRO e BESEN, 2007; ABREU, 2008; ALENCAR, 2008; LIMA e OLIVEIRA, 2008; DIAS, 2009; BAEDER, 2010; IPEA, 2010) mostraram a importância da prestação de serviço da coleta seletiva pelas organizações de catadores, seus avanços, limites e desafios. Nos últimos cinco anos houve aumento de estudos acadêmicos que abordam a coleta seletiva em municípios, as organizações de catadores, principalmente seu perfil socioeconômico e as condições de trabalho, as redes de catadores, e as redes de apoio aos catadores, e diagnósticos visando o fortalecimento institucional, a capacitação e a elaboração de Planos de Negócios.

No entanto, verificou-se na literatura que os estudos focados na sustentabilidade da coleta seletiva com inclusão social de catadores são escassos e observa-se uma carência de artigos que abordem a questão sob a ótica dos indicadores.

A sustentabilidade da coleta seletiva no país diferencia-se pelo forte componente social de inclusão dos catadores, o que não ocorre nos EUA e na União Européia (MILANEZ, 2002; MEDINA, 2007), mas que cresce em países 
da América Latina e Caribe, destacando-se Brasil, Colômbia, Peru e Argentina (GÜNTHER e GRIMBERG, 2006, MEDINA, 2007; WIEGO, 2009; GTZ, 2010).

$\mathrm{Na}$ pesquisa aqui apresentada desenvolveu-se um processo de construção e de validação participativa de conceitos, indicadores e índices de referência para a gestão, avaliação e monitoramento para a coleta seletiva municipal, e para as organizações de catadores o que ocorreu mediante avaliações de especialistas que atuam no país e em oficinas com vários atores sociais, e na perspectiva da sustentabilidade econômica, ambiental, social, de saúde, e institucional.

A hipótese da pesquisa é de que a sustentabilidade da prestação do serviço de coleta seletiva municipal, com a integração de organizações de catadores, e a sustentabilidade de organizações de catadores podem ser avaliadas a partir de um grupo de indicadores construídos e avaliados de forma participativa, por diferentes atores, para contribuir no aprimoramento das políticas públicas de resíduos sólidos.

Observa-se que, no levantamento sobre a produção acadêmica e técnica sobre o tema, não foram identificados indicadores de sustentabilidade, em âmbito nacional e internacional, que tenham sido validados de forma participativa tanto para a coleta seletiva municipal como para as organizações de catadores. Considera-se, portanto, que indicadores e índices para avaliar a sustentabilidade da coleta seletiva e das organizações de catadores, construídos de forma participativa podem ser instrumentos relevantes para planejar, gerenciar, monitorar, assim como de propor metas e alternativas de gestão e promover o fortalecimento institucional e organizacional das organizações de catadores. Estes indicadores e índices também podem apoiar a elaboração das políticas públicas e o direcionamento de investimentos. 


\section{RESÍDUOS SÓLIDOS: DESENVOLVIMENTO SUSTENTÁVEL E SAÚDE PÚBLICA}

As inter-relações entre os conceitos de saúde e de desenvolvimento sustentável, em suas dimensões: ambiental, econômica, sociocultural, e institucional, tornam-se cada vez mais evidentes.

É consensual que saúde não é mais definida como "ausência de doença" (OMS, 2007). O paradigma explicativo para as condições de saúde, mais usado na atualidade é de "determinantes sociais e ambientais da saúde" que incluem as condições socioeconômicas, culturais e ambientais de uma sociedade, relacionando-se com as condições de vida e trabalho de seus membros, tais como habitação, saneamento, ambiente de trabalho, serviços de saúde e educação, incluindo também as redes sociais e comunitárias (BRASIL, 2008; OPS, 2010).

Em 2005 a Organização Mundial da Saúde (OMS) criou a Comissão sobre determinantes sociais da saúde, que concluiu seus trabalhos em 2008 propondo reativar o debate mundial sobre o tema com a publicação do informe mundial "Alcanzar la equidad sanitária actuando sobre los determinantes sociales de la salud" (OPS, 2010).

O conceito de desenvolvimento adotado na pesquisa é o de SEN (2000, p.10) que considera que "desenvolvimento consiste na eliminação de privações de liberdade que limitam as escolhas e as oportunidades das pessoas de exercer ponderadamente sua condição de agente". O conceito de desenvolvimento sustentável por sua vez representa um importante avanço ao considerar a complexa relação entre o desenvolvimento e o meio ambiente numa variedade de áreas. A sua adoção por organismos internacionais afirma uma filosofia do desenvolvimento a partir de um tripé que combina eficiência 
econômica com justiça social e prudência ecológica, como premissas da construção de uma sociedade solidária e justa. As dimensões apontadas pelo conceito de desenvolvimento sustentável contemplam o cálculo econômico, o aspecto biofísico e o componente sociopolítico, enquanto referenciais para a interpretação do mundo e para possibilitar interferências na lógica predatória prevalecente (GUIMARÃES, 1997; JACOBI, 2000; VEIGA, 2005).

Na perspectiva do desenvolvimento sustentável, as interações entre o ambiente e saúde humana geralmente são complexas, destacando-se os impactos relacionados à poluição do ar, qualidade da água, e déficit ou ausência de saneamento básico, incluindo-se os resíduos (EEA, 2010).

A geração excessiva de resíduos domiciliares, sua natureza, composição e grau de periculosidade representam risco ao ambiente e à saúde da população (GLEISER, 2002).

Coloca-se, portanto, o desafio de reduzir a produção e descarte excessivos, assim como a destinação final no solo, em aterros sanitários e lixões. As distintas etapas do gerenciamento de resíduos sólidos, desde a sua geração até a disposição final, envolvem fatores de risco à saúde para as populações expostas, especialmente às pessoas que trabalham em contato direto com os resíduos e à população que mora próxima às áreas de disposição final (OPS, 2005).

Segundo GOUVEIA (2009), embora não existam estudos nacionais e locais conclusivos sobre riscos à saúde da população que reside em áreas próximas a equipamentos como: aterros sanitários, usinas termelétricas de transformação em energia, do metano emitido por resíduos, e incineradores, é necessário promover estudos epidemiológicos associados ao espaço e à distribuição geográfica de doenças e exposições.

Por outro lado, uma das grandes preocupações atuais em termos de riscos à saúde são as mudanças climáticas globais. Sua relação com a temática dos resíduos sólidos (geração excessiva, disposição inadequada e queima) se 
explicita em questões como a poluição do ar (emissões de $\mathrm{CO}_{2}$, metano, e outros gases de efeito estufa); da água (cursos d'água, represas e águas subterrâneas) e do solo (áreas degradadas e contaminadas) (BESEN et al., 2010). Os resíduos, ao serem dispostos inadequadamente, também ocasionam assoreamento de cursos d'água e represas; problemas na infra-estrutura de drenagem urbana e contribuem com a proliferação de vetores transmissores de doenças, de importância sanitária (TCHOBANOUGLOS et al., 1993). De forma geral, mudanças no clima global podem provocar a expansão de áreas de doenças típicas de clima quente para zonas de clima mais temperadas e o recrudescimento de vetores de doenças, causando pandemias. Para NOBRE et al. (2010) um dos efeitos tardios após as enchentes é a maior probabilidade de contrair doenças infecciosas de veiculação hídrica, notadamente as parasitoses intestinais, as hepatites virais, a leptospirose e as enteroviroses. As chuvas intensas criam as condições para a reprodução de mosquitos transmissores de doenças como a dengue, a febre amarela e a malária. O processo pode ser acelerado pelo aumento da temperatura que favorece a eclosão das larvas dos mosquitos vetores.

A coleta seletiva de materiais recicláveis e a reciclagem promovem a redução dos resíduos, o reaproveitamento e a redução da disposição no solo e contribuem de forma direta com a sustentabilidade urbana e a saúde ambiental e humana. Não foram identificados no decorrer da pesquisa, levantamentos globais sistematizados sobre os gastos em saúde, ou internações no Sistema Único de Saúde (SUS), a partir de problemas causados pelos impactos diretos e indiretos da má gestão dos resíduos sólidos. Com relação ao saneamento (esgoto), estudo do Instituto Trata Brasil realizado pela Fundação Getúlio Vargas, em 2010 apontou que a universalização da rede de esgoto no país geraria uma economia de $R \$ 745$ milhões em gastos de internação no SUS ao longo dos anos. 
Segundo a Avaliação Ecossistêmica do Milênio (ADEDIPE et al., 2005), nas últimas três décadas, as políticas e as práticas de gerenciamento de resíduos sólidos resultaram em respostas positivas para a melhoria dos ecossistemas.

No entanto, o principal desafio na gestão dos resíduos sólidos é a garantia de uma gestão integrada. Isto implica em se articular as dimensões de sustentabilidade (econômica, ambiental, social e institucional).

ADEDIPE et al. (2005) consideram que:

1. Os aspectos econômicos contemplam os custos e benefícios de sua implantação, a disponibilidade orçamentária e os impactos de outros setores da economia em termos de investimentos;

2. A dimensão ambiental inclui os aspectos em nível local, regional e global. No plano local, o risco de aumento de epidemias e poluição do solo e das águas subterrâneas, no plano regional, a depleção de recursos e a chuva ácida e; no plano global, o aquecimento global e a depleção da camada de ozônio;

3. Os aspectos sociais incluem os impactos no emprego formal e informal, impactos na saúde humana e aspectos éticos como o uso do trabalho infantil;

4. A dimensão institucional do gerenciamento integrado dos resíduos tem como meta desenvolver um sistema que envolva as principais partes interessadas. A noção de integração implica em considerar os diferentes aspectos da sustentabilidade (técnico, ambiental, de saúde pública, econômicos); opções diferenciadas de gestão, de escala territorial e diferentes envolvimentos de partes interessadas na gestão (forma, informal, governamental e não governamental); e ainda a 
inter-relação com outros setores de ação da gestão pública municipal (drenagem, energia, agricultura, etc.).

De acordo com a Agência de Proteção Ambiental Americana (EPA, 2010), a redução da geração de resíduos sólidos, a coleta seletiva, a reciclagem e a compostagem dos resíduos orgânicos são estratégias eficientes para reduzir a emissão de gases de efeito estufa.

A EPA (2010) atribui a redução de emissões a quatro fatores:

1. A manufatura de novos produtos a partir de materiais recicláveis reduz 0 consumo de energia no processo em comparação ao uso de matérias primas virgens. O reuso também economiza energia na medida em que se utiliza menos energia para extrair, transportar e processar matérias primas virgens na produção de produtos manufaturados. A economia de energia implica em menos fontes de energia fóssil queimada e menos dióxido de carbono emitido na atmosfera;

2. A redução de emissões decorrentes do processo de incineração. A reciclagem e a prevenção da geração de resíduos desviam alguns materiais dos incineradores e reduzem a emissão de gases de efeito estufa decorrentes da queima dos resíduos;

3. A redução da emissão de gás metano dos aterros sanitários. A prevenção da geração de resíduos na fonte, em especial de papéis, e de matéria orgânica (sobras de alimentos) reduz a produção do gás metano, um gás de efeito estufa;

4. O incremento do depósito de carbono nas árvores. As árvores absorvem o dióxido de carbono da atmosfera e o depositam na madeira, e esse processo é denominado de "seqüestro de carbono." A prevenção ao 
desmatamento permite a continuidade da remoção do dióxido de carbono da atmosfera

A reciclagem e a compostagem, dentre as várias formas de tratamento e disposição final de resíduos domiciliares (conforme a Tabela 1), apresentam melhores resultados na redução das emissões de gases de efeito estufa, de emissão de materiais particulados, substâncias tóxicas e carcinogênicas (TELLUS, 2008; EPA, 2010).

Tabela 1- Emissões evitadas de gás carbônico (CO2e), materiais particulados $\left(\mathrm{PM}_{2,5}\right)$, e substâncias tóxicas (Toluenoe) e cancerígenas (Benzenoe) por tonelada de resíduo sólido tratado ou disposto.

\begin{tabular}{|c|c|c|c|c|}
\hline \multirow{3}{*}{$\begin{array}{l}\text { Método de } \\
\text { manejo de } \\
\text { RSD }\end{array}$} & \multicolumn{4}{|c|}{$\begin{array}{l}\text { Emissões (evitadas) } \\
\mathrm{Kg} / \mathrm{t} \text {. de resíduo sólido tratado ou disposto }\end{array}$} \\
\hline & \multirow{2}{*}{$\begin{array}{l}\text { Efeito } \\
\text { estufa } \\
\mathrm{CO}_{2} \mathrm{e}^{4}\end{array}$} & \multicolumn{3}{|c|}{ De interesse à Saúde Humana } \\
\hline & & $\begin{array}{l}\text { Particulados } \\
\mathrm{PM}_{25} \mathrm{e}\end{array}$ & $\begin{array}{c}\text { Tóxicos } \\
\text { Toluenoe }\end{array}$ & $\begin{array}{c}\text { Carcinogênicos } \\
\text { Benzenoe }\end{array}$ \\
\hline $\begin{array}{l}\text { Reciclagem } \\
\text { /compostagem }\end{array}$ & $(1642)$ & $(2,2)$ & $(720)$ & $(0.3204)$ \\
\hline $\begin{array}{l}\text { Aterro } \\
\text { sanitário }\end{array}$ & (229) & 1,3 & 125 & 0.000045 \\
\hline Incineração & (65) & $(0,14)$ & 31 & 0,00086 \\
\hline $\begin{array}{l}\text { Gasificação } \\
\text { /Pirólise }\end{array}$ & $(92,5)$ & $(0,16)$ & $(0,45)$ & (0) \\
\hline
\end{tabular}

Adaptado pela autora. Fonte: TELLUS INSTITUTE, 2008

\footnotetext{
${ }^{4}$ Define-se $\mathrm{CO} 2$ equivalente enquanto a concentração de dióxido de carbono que poderia causar o mesmo grau de eficiência radiativa (habilidade de absorver o calor), que uma determinada mistura de dióxido de carbono e outros gases de efeito estufa. Glossário do Painel Intergovernamental para Mudanças do Clima (IPCC).
} 
Portanto, diante do exposto nesse tópico, a redução da geração excessiva de resíduos e a redução na fonte, o reuso, a reciclagem, e a compostagem, assim como o seu gerenciamento adequado, se configuram enquanto fatores de sustentabilidade e de proteção à saúde humana.

Embora esta pesquisa trate da coleta seletiva de materiais recicláveis (recipientes e embalagens que após o uso podem ser encaminhados para a reciclagem e transformados em novos produtos, a exemplo dos vidros, plásticos, papéis, papelão, ferros, aço e alumínio, dentre outros) é importante destacar os altos índices de matéria orgânica no lixo brasileiro (cerca de 60\%) e os baixos índices de compostagem no Brasil que equivaliam a 3\%, no ano de 2008 (CEMPRE, 2010). Também se destaca que assim como na coleta seletiva organizações de catadores podem ser envolvidas na operação de unidades de compostagem com objetivo de ampliar a geração de trabalho e renda e melhorar os índices no país.

No que se refere aos catadores de materiais recicláveis, entende-se a interdependência entre saúde, coleta seletiva e sustentabilidade, na perspectiva dos determinantes sociais da saúde. O estímulo à sua organização e o fortalecimento de sua relação com a coleta seletiva, como prestadores de serviço, a sua valorização enquanto agentes ambientais, a melhoria da autoestima, da renda obtida e das condições de trabalho e vida podem influenciar positivamente a sua saúde.

A organização dos catadores e as políticas públicas de apoio podem afetar de forma positiva a saúde desses trabalhadores como demonstrado na pesquisa do BNDES, de fevereiro de 2009 (CEMPRE INFORMA, 2010). Essa pesquisa, junto a $59 \%$ do universo de cooperativas apoiadas pelo Banco identificou avanços significativos na qualidade de vida dos cooperados e suas famílias, bem como aumento da eficiência nas atividades. Quanto à gestão operacional houve incremento do material coletado em $20,6 \%$, processado em $25,5 \%$ e da capacidade de processamento instalada. Quanto às condições de 
vida, a pesquisa revelou melhoras no relacionamento familiar em $82 \%$, nas condições de higiene em 79,6\%, na alimentação dos cooperados e de suas famílias em $78,85 \%$ e no conforto das moradias em $69,3 \%$. Também foram apontados outros fatores positivos, como melhorias no ambiente de trabalho e no relacionamento entre os cooperados, bem como na conscientização de seus direitos e deveres.

ALENCAR (2008) também verificou melhorias nas condições de vida de catadores organizados, em Recife. Para LIMA e OLIVEIRA (2008, p. 243) o modelo de coleta seletiva com inclusão de catadores poupa a sociedade dos custos ambientais e economiza recursos destinados a ações sociais públicas, como prevenção do trabalho infantil, aumento da escolarização, redução da violência, controle de drogas, diminuição da mortalidade infantil e cuidados de saúde em geral. 


\section{DIFERENCIAL DA COLETA SELETIVA NO BRASIL}

No Brasil verifica-se o aumento de geração de resíduos sólidos urbanos Segundo estimativas da ABRELPE (2009), a geração de resíduos sólidos urbanos foi de 57 milhões de toneladas, em 2009, um crescimento de $6,6 \%$ na geração per capita em relação ao ano de 2008. De acordo com estimativas do Compromisso Empresarial para a Reciclagem (CEMPRE), entre os anos de 1999 e 2008 o índice de reciclagem de resíduos urbanos no Brasil, em relação ao total passou de 4\% para 13\%. Em relação à fração seca, de resíduos sólidos urbanos, em 2009 o volume de materiais recicláveis atingiu $25 \%$, o que mostra que muito se tem a avançar em termos de coleta seletiva e reciclagem (CEMPREINFORMA, 2009).

A proporção de materiais reciclados em algumas atividades industriais, entre os anos de 1993 e 2008 avançou muito e atingiu em alguns casos, como no de latas de alumínio e de garrafas PET, o topo do ranking mundial de reciclagem. Entre os anos de 1994 e 2008, o índice de reciclagem: de latas de alumínio variou de $56 \%$ para $91,5 \%$, o de papel de $37,5 \%$ para $43,7 \%$, o de vidro de $33 \%$ para $47 \%$, o de embalagens PET de $18,8 \%$ para $54,8 \%$, os de lata de aço de $23 \%$ para $46,5 \%$ e os de embalagens longa vida, de $10 \%$, no ano de 1999 para 26,6\%, em 2008 (IBGE, 2010a).

O desempenho positivo da cadeia de reciclagem deve-se a forma com que se estruturou no país, baseando-se no trabalho informal de milhares de catadores. Nesse contexto, a organização de catadores em associações e cooperativas se torna uma alternativa para gerar benefícios sociais, econômicos e ambientais, incluindo a questão da saúde dos trabalhadores.

Cabe enfatizar que as políticas sociais implementadas nos últimos oito anos pelo governo federal promoveram o acesso de mais de 30 milhões de 
pessoas ao mercado de consumo (IPEA, 2010), e a previsão para os próximos anos é de intensificação destas políticas, e conseqüentemente do consumo e descarte.

O país tem se destacado no mercado mundial da reciclagem e no desenvolvimento de um modelo de coleta seletiva socialmente justo que prioriza a inclusão social de catadores de materiais recicláveis.

Para DIAS (2009):

"O Brasil tem despontado como o país onde
avanços significativos têm sido alcançados
não somente em termos do processo de
organização deste segmento social, como
também no plano do reconhecimento da
atividade pelo poder público. Nas últimas duas
décadas, o fenômeno da catação tem,
paulatinamente, sido encarado enquanto uma
questão sócioambiental inserindo-se no
âmbito da política e da justiça social, à medida
que tem passado a ser objeto de políticas
públicas em nível nacional, estadual e
municipal".

No entanto, os altos índices de reciclagem de algumas embalagens no Brasil, ainda se baseiam em uma cadeia produtiva injusta com os catadores, de materiais recicláveis que são os que auferem o menor ganho em relação aos demais (INSTITUTO ETHOS, 2007).

Os resíduos sólidos são recursos não naturais em crescimento aos quais os catadores sempre tiveram acesso informal. Os catadores lutam pelo acesso justo e equitativo a esses recursos (ACSELRAD, 2002; WIEGO, 2009, DIAS, 2009).

Ao longo dos anos, os catadores defendem seu direito ao trabalho e à participação no sistema de gestão de resíduos sólidos, dentro do conceito de gestão compartilhada. Buscam a autogestão embasada nos princípios da economia solidária (SINGER, 2002; SINGER e SOUZA, 2002) e tem como meta a inclusão social dos catadores que atuam nas ruas. Entendem que a 
organização de catadores em associações e cooperativas representa uma alternativa às políticas de emprego convencionais e a busca de práticas de promoção da sustentabilidade e da justiça ambiental com inclusão social. Expressam assim a reação de um segmento excluído que foca 0 reconhecimento do seu direito ao trabalho como central na conquista da sua cidadania. (ESCOREL, 1999; SINGER e SOUZA, 2002; ACSELRAD, 2002).

\subsection{POLITICAS PÚBLICAS DE INCLUSÃO DE CATADORES}

A construção da política pública de resíduos sólidos no Brasil se dá no âmbito da política ambiental com inclusão social e no contexto da gestão dos serviços urbanos de limpeza pública (RIBEIRO e BESEN, 2007; BESEN, 2008; RIBEIRO et al., 2009). Este modelo é defendido desde a década de 1990 por organizações da sociedade civil, pelo Movimento Nacional dos Catadores (MNCR), por técnicos do poder público e por acadêmicos. O enfrentamento dos desafios socioambientais para o desenvolvimento local exige novos modelos de cooperação e parcerias entre o governo e a sociedade que articulem inclusão social, geração de renda e preservação ambiental (BURSZTYN, 2000; JACOBI, 2000; JACOBI, 2006).

Em 2002, com a instalação do Governo do presidente Luiz Inácio Lula da Silva, e no âmbito do projeto Fome Zero, o MNCR iniciou uma interlocução direta com o Presidente da República, e a questão foi priorizada na esfera nacional. A partir daí várias políticas públicas afirmativas de inclusão dos catadores e de financiamentos visando ao fortalecimento e à sustentabilidade das organizações de catadores têm sido viabilizadas.

As organizações de catadores têm obtido recursos para: aquisição de equipamentos, construção de centrais de triagem, cursos de formação, melhorias nas condições sanitárias e de trabalho e fortalecimento de redes 
entre as organizações visando ampliar as vendas coletivas dos recicláveis para a indústria na lógica do comércio e com preços mais justos.

Dentre as principais políticas e ações do governo federal, para inserção das cooperativas de catadores na cadeia de reciclagem e ampliação do mercado de reciclagem no Brasil destacam-se:

- A criação da categoria de catador de material reciclável pelo Ministério do Trabalho e Emprego, no Cadastro Brasileiro de Ocupações (CBO), em 2002, sob o código único 5192. Com o reconhecimento da atividade se estabeleceu para a categoria os mesmos direitos e obrigações de um trabalhador autônomo;

- A criação do Comitê Interministerial da Inclusão Social de Catadores (Decreto Federal de setembro de 2003), composto por representantes da Casa Civil da Presidência da República, de 11 Ministérios, Coordenado pelos Ministérios das Cidades e do Desenvolvimento Social de Combate à Fome e parceiros do Programa Fome Zero, bancos e fundações públicas. Este Comitê tem como principais objetivos: garantir condições dignas de vida e trabalho à população catadora de resíduos, apoiar a gestão e destinação adequada de resíduos sólidos nos municípios, articular as políticas setoriais e acompanhar a implementação dos programas voltados aos catadores de recicláveis;

- A aprovação da Política Nacional de Saneamento Básico- Lei Federal № 11.445, de janeiro de 2007, a qual modificou o inciso XXVII do caput do art. 24 da Lei de Licitações № 8.666/1993 e autorizou as prefeituras a contratarem as associações/ cooperativas de catadores de materiais recicláveis para execução as atividades de coleta, processamento e comercialização de resíduos sólidos urbanos recicláveis ou reutilizáveis; 
- O Decreto Federal № 5.940, de outubro de 2006, instituiu a separação dos resíduos recicláveis descartados pelos órgãos e entidades da administração pública federal direta e indireta, na fonte geradora, e a sua destinação às associações e cooperativas dos catadores de materiais recicláveis;

- A aprovação da Lei Federal № 12.017, de agosto de 2009, que dispõe sobre as diretrizes para a elaboração e execução da Lei Orçamentária de 2010, altera a Lei de Diretrizes Orçamentárias do Governo Federal e permite a transferência de recursos diretos para as cooperativas, sem a intermediação de prefeituras ou Organizações Sociais de Interesse Público (OSCIPS);

- A Medida Provisória № 476, de 23 de dezembro de 2009 que dispõe sobre a concessão de crédito presumido do Imposto sobre Produtos Industrializados IPI para a aquisição de resíduos sólidos por estabelecimento industrial para utilização como matérias-primas ou produtos intermediários na fabricação de seus produtos. Esta medida estabelece que a isenção seja usufruída se os resíduos sólidos forem adquiridos diretamente de cooperativa de catadores de materiais recicláveis com número mínimo de cooperados pessoas físicas definido em ato do Poder Executivo;

- Em tramitação projeto de Lei Federal 510/09, apresentado em novembro de 2009 que desonera do Imposto sobre Produtos Industrializados (IPI) as empresas nas quais os resíduos recicláveis representem ao menos $70 \%$ do custo de matérias-primas usadas no processo produtivo;

- A intenção de realizar o Pagamento por Serviços Ambientais Urbanos para a gestão de resíduos urbanos. Para subsidiar a elaboração de uma Política Nacional de Pagamento por serviços ambientais urbanos (Psau) foi demandado pelo Ministério do Meio (MMA) estudo ao Instituto de Pesquisa Econômica Aplicada (IPEA, 2010). O instrumento consiste em pagamentos às cooperativas 
de catadores por tonelada de resíduos coletados e triados. A proposta do estudo é criar um Fundo Cooperativo que poderá ser operacionalizado por bancos públicos; fundos federais, ou na forma de uma cooperativa de crédito ou banco popular. Com o Psau o governo pretende: elevar a renda média dos catadores, reduzir a oscilação dos preços pagos aos catadores pelos recicláveis, estimular as cooperativas, incentivar o aumento da eficiência e a sustentabilidade das cooperativas a médio e longo prazos. Representa um importante avanço para as organizações de catadores. O estudo se encontra em discussão e o MNCR já manifestou críticas e propostas;

- A aprovação da Política Nacional de Resíduos Sólidos (PNRS), Lei Federal № 12.305, de julho de 2010 e sua regulamentação por meio do Decreto № 7.404, de dezembro de 2010 que também cria o Comitê Interministerial da Política Nacional de Resíduos Sólidos e o Comitê Orientador para a Implantação dos Sistemas de Logística Reversa.

Após tramitar durante 20 anos no Congresso Nacional, a PNRS estabelece um marco regulatório para o país, centrado nos princípios atuais da gestão integrada e sustentável de resíduos; a prevenção e a precaução, cuja lógica é a não geração, redução, reutilização e reciclagem, além da disposição final ambientalmente adequada dos rejeitos em aterros sanitários. A lei exige, no prazo de dois anos, a elaboração de planos de resíduos sólidos em âmbitos: nacional, estadual e municipal que erradiquem os lixões. Esses planos devem apresentar metas de redução, reutilização e reciclagem, com o objetivo de reduzir a quantidade de resíduos e rejeitos encaminhados para disposição no solo.

A PNRS propõe a responsabilidade compartilhada pelo ciclo de vida dos produtos enquanto o conjunto de atribuições individualizadas e encadeadas dos fabricantes, importadores, distribuidores e comerciantes, dos consumidores e dos titulares dos serviços públicos de limpeza urbana e manejo dos resíduos 
sólidos pela minimização do volume de resíduos sólidos e rejeitos gerados, bem como pela redução dos impactos causados à saúde humana e à qualidade ambiental decorrentes do ciclo de vida dos produtos. A partir desta categoria de responsabilidade os "fabricantes, importadores, distribuidores e comerciantes são considerados responsáveis pelo recolhimento e destinação ambientalmente adequada dos produtos pós-consumo". Os sistemas de retorno dos produtos (logística reversa) devem ser estruturados de forma independente do serviço de limpeza urbana.

A lei prevê acordos setoriais a serem firmados entre o poder público e o setor empresarial que viabilizem a implementação dos sistemas de coleta seletiva previstos nos planos municipais de gestão integrada de resíduos sólidos. Está prevista a possibilidade de o setor empresarial remunerar o poder público municipal para operar a logística reversa, caso este inclua na gestão dos RSU esta etapa.

Quanto às organizações de catadores, existem na Lei várias referências das quais se destacam:

a) A PNRS define como princípios e objetivos (art. 6 ítem XI) a integração dos catadores de materiais reutilizáveis e recicláveis nas ações que envolvam a responsabilidade compartilhada pelo ciclo de vida dos produtos;

b) Em seus instrumentos (Art. $8^{\circ}$ IV) define o incentivo à criação e ao desenvolvimento de cooperativas ou de outras formas de associação de catadores de materiais reutilizáveis e recicláveis e à priorização de recursos da União para municípios que implantarem coleta seletiva com inclusão de organizações de catadores;

c) Enquanto instrumentos econômicos (Art. 44) propõe que a União, os Estados, o Distrito Federal e os Municípios, no âmbito de suas competências, poderão instituir normas e conceder incentivos fiscais, 
financeiros ou creditícios, às empresas recicladoras e organizações de catadores, respeitadas as limitações da Lei de Responsabilidade Fiscal (Lei Complementar oㅜ 101, de maio de 2000). Cabe também destacar que a PNRS propõe medidas de incentivo à formação de consórcios públicos ${ }^{5}$ para a gestão regionalizada. Desta forma pretende ampliar a capacidade de gestão das administrações municipais por meio de ganhos de escala e redução de custos no caso de compartilhamento de sistemas de coleta, tratamento e destinação de resíduos sólidos. Quanto aos catadores possibilita o fortalecimento das redes de organizações de catadores e a criação de centrais de estocagem e comercialização regionais.

Segundo a regulamentação da PNRS o governo federal deverá elaborar, até junho de 2011, um Plano que inclua metas de redução e reciclagem com a participação de 12 ministérios, e coordenados pelo Ministério do Meio Ambiente. As metas de reciclagem serão definidas em arenas de negociação entre o setor público e privado e mediante acordos setoriais.

$\mathrm{Na}$ medida em que o modelo a ser adotado no Brasil ainda não está definido, os catadores enfrentarão mais um grande desafio no sentido de se inserir nesse modelo e garantir o seu espaço na cadeia produtiva da reciclagem que deve considerar a inclusão social nesse pacto.

\subsection{ORGANIZAÇÃO SOCIAL E POLÍTICA DOS CATADORES}

No Brasil estima-se que existam aproximadamente 230.000 catadores de materiais recicláveis (PNAD, 2006).

\footnotetext{
${ }^{5}$ Contratação de Consórcios Públicos. Lei Federal 11.107/2005 e Decreto 6.017/07. Disponível em: http://www.planalto.gov.br/ccivil_03/_Ato2004-2006/2005/Lei/L11107.htm.
} 
O Movimento Nacional dos Catadores realizou, em 2006 (MNCR, 2006), o estudo mais abrangente do país sobre organizações de catadores, até o momento (Quadro 1).

Quadro 1: Situação e características dos grupos associados ao MNCR

\begin{tabular}{|c|c|c|c|c|c|}
\hline \multicolumn{6}{|c|}{ Grupos de catadores } \\
\hline Situação & $\begin{array}{c}\text { N. } \\
\text { Membros }\end{array}$ & $\%$ & $\begin{array}{c}\text { N. } \\
\text { Grupos }\end{array}$ & $\%$ & Características \\
\hline $\begin{array}{l}\text { Formalmente } \\
\text { organizados } \\
\text { (A) }\end{array}$ & 1.381 & 4 & 24 & 7 & $\begin{array}{l}\text { Equipamentos } \text { e galpões } \\
\text { próprios, e capacidade de } \\
\text { implantar unidades de reciclagem }\end{array}$ \\
\hline $\begin{array}{l}\text { Formalmente } \\
\text { organizados } \\
\text { (B) }\end{array}$ & 2.753 & 8 & 70 & 21 & $\begin{array}{l}\text { Alguns equipamentos próprios. } \\
\text { Precisam de apoio para a } \\
\text { compra de equipamentos e/ou } \\
\text { construção de galpões. }\end{array}$ \\
\hline $\begin{array}{l}\text { Em } \\
\text { organização }\end{array}$ & 5.720 & 16 & 122 & 37 & $\begin{array}{l}\text { Poucos equipamentos. Precisam } \\
\text { de apoio para a aquisição de } \\
\text { equipamentos e de galpões. }\end{array}$ \\
\hline $\begin{array}{l}\text { Desorganizado } \\
\text { (atuando nas } \\
\text { ruas ou lixões) }\end{array}$ & 25.783 & 72 & 115 & 35 & $\begin{array}{l}\text { Não possuem equipamentos, } \\
\text { condições de trabalho precárias, } \\
\text { e venda para atravessadores e } \\
\text { depósitos de sucata }\end{array}$ \\
\hline Total & 35.637 & & 331 & & \\
\hline
\end{tabular}

Extraído de: MNCR, 2006, baseado em dados do cadastro de 2005.

Foram identificados dentre seus associados, 35.637 catadores e 331 organizações, atuando em quatro situações diferenciadas.

Em 2006, os grupos formalmente organizados representavam apenas $7 \%$ das organizações filiadas ao MNCR. A maior parte se encontrava em processo de organização (37\%) ou em situação de total precariedade (35\%), logo não possuía condições e infra-estrutura para desempenhar suas atividades (MNCR, 2006; BESEN, 2008). 
A Pesquisa Nacional por Amostra de Domicílios (PNAD) também apontou a existência de 10.272 catadores que se declaram trabalhadores com "carteira assinada", número próximo ao encontrado na pesquisa RAIS de 2006 (MTE), que é de 11.781 pessoas com vínculos formais de trabalho (CRIVELLARI et al., 2008).

Em 2009, já existiam mais de 3.500 grupos de catadores, dos quais pouco mais de 500 grupos organizados se encontravam filiados ao MNCR (WIEGO, 2009, p. 46).

O processo de organização social de catadores de materiais recicláveis em associações e cooperativas, no Brasil, teve início no final da década de 1980, e tem se consolidado como uma política pública ambiental de coleta seletiva com inclusão social, no contexto da gestão dos serviços urbanos de limpeza urbana (RIBEIRO et al., 2009). Segundo a última PNSB de 2008, 18\% dos municípios brasileiros tem coleta seletiva, a maioria (66\%) conjuntamente com organizações de catadores; muitas organizações de catadores também vêm atuando de forma autônoma em relação às prefeituras.

Apoiado ao longo do tempo por entidades da sociedade civil e técnicos que atuam nas várias esferas de governo, o processo de organização dos catadores foi fortalecido. Inicialmente com a criação do Fórum Lixo \& Cidadania Nacional em 1998, por iniciativa da UNICEF, e posteriormente os fóruns estaduais e municipais. Esses fóruns são constituídos por representantes de diversos segmentos da sociedade civil, poder público e iniciativa privada e atuam enquanto instâncias participativas. A Campanha Criança no Lixo Nunca Mais organizada pela UNICEF, em 1999, consolidou a atuação dos Fóruns. Em seguida as iniciativas de coleta seletiva em parceria com organizações de catadores das cidades de Porto Alegre, Belo Horizonte, como também a experiência da Coopamare, em São Paulo, foram um importante referencial para a implantação da coleta seletiva pelas prefeituras (BESEN, 2006; JACOBI, 2006; DIAS, 2009). 
O amadurecimento dos catadores organizados possibilitou, no ano de 2002, a criação do Movimento Nacional dos Catadores - MNCR, fator decisivo na conquista de espaços de interlocução com a esfera governamental, privada e da sociedade civil.

Nos últimos anos, o MNCR se consolidou enquanto um movimento social que defende o direito ao trabalho e os catadores como atores da coleta seletiva nas cidades na perspectiva da justiça ambiental e social (ACSELRAD, 2002; BESEN, 2006; INSTITUTO ETHOS, 2007). O MNCR é considerado atualmente o maior movimento de recicladores do mundo (MEDINA 2007, p. 82; WIEGO, 2009, p. 44). Constitui um importante exemplo de articulação de atores na ótica da teoria do capital social. O conceito de relação de identidade grupal é a base de formação para a essência do capital social (BOURDIEU, 1998). Para CASTELLS (1999), as diversas formas de articulação de um processo amplificador de desigualdades decorrem da dinâmica de globalização e da compressão do tempo e espaço, formando-se o que denomina de "identidades de resistência" e "identidades de projeto". Considera ainda que as identidades de resistência são formadas por atores que precisam construir formas de resistência e sobrevivência, e expressam, em geral, desacordo com a "nova ordem mundial", lutando por justiça social e cidadania.

De acordo com JACOBI (2000, pg.133), o engajamento dos diversos atores está associado a questões concretas, imediatas, do cotidiano ou que afetam valores aos quais se outorga posição elevada na hierarquia ética. Em alguns casos, pode ser associado a estratégias de ação e oportunidades de poder que configuram uma articulação de interesses difusos na busca de alianças sustentadas em vários eixos: âmbito geográfico de vida, ou grupo étnico, resistência sócio-cultural e luta por direitos. 
É importante destacar também o importante papel que uma rede de entidades nacionais ${ }^{6}$ de apoio tem dado ao MNCR, no desenvolvimento de linhas de financiamento, na captação de recursos, interlocução com as empresas e prestação de serviços de assessoria às redes de organizações de catadores. As organizações de catadores também têm tido apoio do Ministério Público que exige das prefeituras municipais o fechamento dos lixões com a inclusão dos catadores nos sistemas municipais de coleta seletiva.

O MNCR assumiu, dentre muitas outras, como metas: 1) o reconhecimento da categoria de catador de material reciclável, 2) a remuneração dos catadores pelos serviços prestados na coleta seletiva, e 3) a consolidação da coleta seletiva com inclusão socioprodutiva de catadores (BESEN, 2008).

A primeira meta foi alcançada em 2002, com o reconhecimento da atividade de "catador de material reciclável". A segunda avançou em 2007, com a promulgação da Lei da Política Nacional de Saneamento que possibilitou a contratação de associações ou cooperativas formadas exclusivamente, por pessoas físicas de baixa renda reconhecidas pelo poder público como catadores. A terceira meta representa ainda um grande desafio do MNCR, dos Fóruns Lixo e Cidadania e das entidades de apoio e vários passos foram dados par atingi-la. Em 2003, com a criação do Comitê Interministerial para a Inclusão Social e Econômica dos Catadores (decreto federal) foram alavancados investimentos de significativos recursos da esfera federal no fortalecimento da coleta seletiva com inclusão social.

Em 2006, o estudo "Análise do Custo de Geração de Postos de Trabalho na Economia Urbana para o Segmento dos Catadores de Materiais Recicláveis"

\footnotetext{
6 Pastoral de Rua, Organização de Auxílio Fraterno (OAF), Instituto Polis, Associação Pernambucana Defesa da Natureza (ASPAN), Instituto Nenuca de Desenvolvimento Sustentável (INSEA), Instituto Ethos, Centro de Estudos Socioambientais (Pangea), dentre outros, e internacionais, tais como a Fundação AVINA e a Women in Informal Employment: Globalizing and Organizing (WIEGO).
} 
(MNCR, 2006) referenciou a criação de uma linha de investimentos para estruturação de cooperativas de catadores no país. Mostrou que o custo de um posto de trabalho de catadores é baixo em relação a outros setores da economia, podendo-se criar milhares de postos de trabalho com inclusão social na cadeia produtiva da reciclagem. Em 2006, o custo médio de um posto de trabalho de catador era de $\mathrm{R} \$ 4$ mil reais, o menor, comparativamente à reforma agrária ( $R \$ 5,2$ mil), padaria $(R \$ 5,4$ mil), sorveteria $(R \$ 9,6 \mathrm{mil})$ e construção civil ( $R \$ 33,3$ mil), e ainda considerado baixo em relação a outros setores da economia. $O$ estudo mostrou que é possível criar milhares de postos de trabalho, com justiça social na cadeia produtiva da reciclagem.

\subsubsection{Empoderamento, princípios e organização}

O processo de organização dos catadores também foi alavancado pela criação dos Fóruns Lixo \& Cidadania, nacional em 1998 e posteriormente os estaduais e municipais. Constituídos por representantes de diversos segmentos da sociedade civil, poder público e iniciativa privada atuam enquanto instâncias participativas. Apóiam a construção das políticas públicas de resíduos sólidos, a coleta seletiva com inclusão dos catadores, a defesa dos direitos dos catadores e as organizações de catadores. Surgiram no contexto do novo espaço público, denominado não estatal, juntamente com os conselhos, redes, e articulações da sociedade civil com representantes do poder público. Estas novas formas associativas visavam à transparência da gestão pública e responder às demandas sociais do país por meio da construção de políticas públicas, do controle social da aplicação dos recursos e da luta contra a exclusão social (JACOBI, 2000; FARAH, 2001; GOHN, 2004).

A fundação da Federação das Associações de Recicladores do Rio Grande do Sul, em 1998, em Porto Alegre (RS) foi a primeira iniciativa a reunir as várias organizações de catadores do estado (MARTINS, 2004). 
No ano 2000, o MNCR começou a ser organizado a partir de um longo processo de articulação. Em 2001, o 1ํㅡㄹ Congresso Nacional dos Catadores de Materiais Recicláveis reuniu 1.600 catadores, técnicos e agentes sociais de dezessete estados brasileiros. Ainda em 2001, foi constituído o MNCR e por decisão dos catadores representados pelo Movimento, se aprovou a denominação de catadores de materiais recicláveis para a categoria profissional. Em 2002 houve o reconhecimento da atividade de catador pelo Ministério do Trabalho e Emprego (MTE).

Nos anos de 2003 e 2005, a cidade de Caxias do Sul (RS), sediou o I e II Congressos Latino Americano de Catadores (as) de Materiais Recicláveis, no qual foram firmados compromissos contra a privatização do setor de resíduos sólidos e para a implantação da coleta seletiva com as organizações de catadores. O II Congresso teve como principal objetivo fortalecer os movimentos de catadores da América Latina, formando uma rede de solidariedade e de troca de informações Em 2008, o III Congresso Latino Americano na Colômbia e o I Encontro Mundial de Catadores reuniram catadores de 35 países cujo tema central foi o risco da privatização dos serviços de resíduos sólidos. A Carta de Bogota afirma que "os participantes exigem dos poderes públicos e governos que na contratação de serviços de limpeza, priorizem as organizações de catadores dando as condições para sua efetiva inclusão, mediante o desenvolvimento de ações econômicas, sociais e ambientais que concretizem ações afirmativas" "

As nove edições dos Festivais Lixo e Cidadania de Belo Horizonte também foram estratégicas para promover a integração e o fortalecimento dos catadores e o intercâmbio de experiências. Em 2009 e 2010, houve duas edições da ReviraVolta Expocatadores na cidade de São Paulo ${ }^{8}$.

\footnotetext{
${ }^{7}$ Disponível em: http//www.movimentodoscatadores.org.br.

${ }^{8} \mathrm{O}$ evento promove feiras de equipamentos, projetos e reúne representantes de organizações de catadores, da Rede Latino Americana e Caribenha de catadores, apoiadores e técnicos.
} 
A declaração de princípios e objetivos do $\mathrm{MNCR}^{9}$ configura algumas características peculiares que associam aspectos dos movimentos sociais populares das décadas de 1970 e 1980, aos novos movimentos sociais da década de 1990 e aos movimentos atuais, nos quais a luta pela sobrevivência e pela inclusão social nas políticas públicas está presente.

A organização do MNCR, a partir do ano 2000, diferencia-se do universo das ONGS atuais, e se deu no contra fluxo dos registros históricos dos movimentos sociais populares, pois se caracteriza por interesses específicos de um único grupo de atores sociais, os catadores. Apresenta similaridades tanto com movimentos populares de contestação e pressão junto ao Estado, tais como o Movimento dos Sem Terra (MST) e o Movimento dos Atingidos por Barragens (MAB), quanto aos "novos movimentos sociais" que defendiam as minorias ou uma atuação por afinidades de sentido em torno de temas específicos, tais como; os movimentos; feminista, de moradia, negro, homossexuais, deficientes, entre outros (HABERMAS, 1987; LAVALLE et al., 2006).

Dentre os objetivos e princípios do MNCR destacam-se; a autogestão e organização $^{10}$, a participação de todos os (as) catadores (as), a democracia direta $^{11}$, e a ação direta popular ${ }^{12}$. A democracia direta e participativa era um conceito utilizado pela sociedade civil na década de 1970, como o modelo ideal para a construção de uma contra hegemonia ao poder dominante (DAGNINO, 2002; GOHN, 2004). O MNCR busca a "independência de classe, o apoio mútuo e a solidariedade de classe". Defende o reconhecimento e valorização do trabalho do catador, a remuneração pelos serviços prestados ao poder público e à iniciativa privada na coleta seletiva, o direito à cidade, moradia digna,

\footnotetext{
${ }^{9}$ Disponível em: http//www. movimentodoscatadores.org.br

${ }^{10}$ Autogestão é a prática econômica em que os trabalhadores são os donos das ferramentas de produção...sem patrões.

${ }^{11}$ Democracia direta é forma de decisão tomada pela participação coletiva e responsável da base.

${ }^{12}$ Ação direta é um princípio e método que carrega o sentido do protagonismo do povo auto organizado.
} 
educação, saúde, alimentação, transporte e lazer. E ainda, o fim dos lixões, construção de galpões com condições dignas para os catadores e coleta seletiva.

Segundo SAMSOM (In: WIEGO 2009), o MNCR apresenta uma análise classista da sociedade e considera que os catadores são parte de uma classe mais ampla de oprimidos. Para o MNCR não se pode alcançar as metas de forma isolada e "a vitória exige uma transformação integral da sociedade para erradicar as relações de poder e as desigualdades que a dividem entre opressores e oprimidos, ricos e pobres". Sua organização se dá de forma horizontal a partir das bases e vertical em diversas instâncias de representação integradas por delegados eleitos. A base é constituída por catadores vinculados a associações e cooperativas que se articulam em Comitês Regionais e Coordenações Estaduais, e a articulação nacional é realizada pela Comissão Nacional ${ }^{13}$.

\subsubsection{Redes nacionais e internacionais de catadores}

Nos últimos cinco anos as organizações de catadores têm formado redes, locais e regionais para a comercialização conjunta e ampliação da capacidade de negociação com as indústrias recicladoras para a venda direta dos materiais recicláveis. Segundo DAMÁSIO (2008) as redes de comercialização introduzem novas estratégias logísticas e organizacionais no curto-prazo, capazes de gerar ganhos em eficiência, com razoável poder de difusão, e com o potencial de melhorar o padrão de vida dos catadores membros das cooperativas ${ }^{14}$.

\footnotetext{
${ }^{13}$ Movimento Nacional dos Catadores. Disponível em: http://www.movimentodoscatadores.org.br/estruturas_regionais.aspx.

${ }^{14}$ Não foi identificado no decorrer da pesquisa levantamento do número de redes existentes. Destacam-se as redes: Cata Sampa (SP), Cata Bahia (BA), Cata Unidos (MG), Rede de Comercialização do ABC/SP (SP), Rede Cata Rio (RJ) e Rede Cata Vida (SP).
} 
Para Aquino et al. (2009) que estudaram a cadeia produtiva da reciclagem na grande Florianópolis (Santa Catarina - Brasil), quando as organizações de catadores atuam de forma isolada nem todas têm potencial para realizar a comercialização direta à indústria, porém atuando em rede as associações podem obter uma agregação média de valor aos materiais recicláveis de aproximadamente $32 \%$. Para o papel chegou a $63 \%$, plástico, $44 \%$ ferro, $25 \%$. No entanto para o alumínio e para o vidro não houve valor agregado.

A incorporação de novas tecnologias de informação possibilita a formação de redes sociais locais, nacionais e transnacionais, a globalização das agendas dos movimentos sociais e de suas formas de luta (FINGER, 1994). A construção de novas relações entre atores na sociedade civil, estado e organizações internacionais, faz com que se multipliquem os canais de acesso a informações. As redes caracterizam-se pela não centralidade organizacional e não-hieraquização do poder, as relações são mais horizontalizadas, complementares e mais abertas ao pluralismo e à diversidade cultural (SCHERER-WARREN, 1993).

Outras redes mais amplas, nacionais e internacionais são articuladas pelo MNCR que integra a Rede Latino Americana de Recicladores. Outros quatro movimentos nacionais de catadores e recicladores, do Chile, do Peru, da Colômbia e da Índia e representantes de catadores de mais 11 países integram a Rede. Segundo a FUNDAÇÃO AVINA (2009), essa Rede tem avançado nos temas de reciclagem e mudança climática e introduziu, nos convênios internacionais sobre mudança climática, uma aliança global para promover a reciclagem como atividade redutora dos gases do efeito estufa $A$ aliança global inclui a Rede Latino Americana de Catadores, organizações de catadores da Índia e as ONGs WIEGO e Global Alliance for Incinerator Alternatives (GAIA). Atualmente a principal luta do MNCR e da Rede Latino Americana é contra a incineração de resíduos sólidos domiciliares. 
De acordo com a AVINA ${ }^{15}$, a Fundação "facilitou a participação dos catadores da Rede na agenda preparatória da Conferência das Partes da Convenção do Clima (COP15), apoiou a estratégia de comunicações e colaborou na logística para permitir a presença dos catadores nas reuniões estratégicas nacionais e internacionais, incluindo a XV Conferência em Copenhague, em 2009.

A Fundação AVINA esta envolvida, desde o ano de 2008, em dois grandes projetos que visam ao fortalecimento dos catadores ${ }^{16}$. Um dos projetos tem a participação da Rede Latino Americana de Recicladores com financiamento parcial da Fundação Bill \& Melinda Gates (US\$5 milhões). Esse projeto tem a finalidade de apoiar atividades de reciclagem sustentável na América Latina, aumentar a inclusão social e econômica, assim como reforçar a Rede administrativamente. O segundo projeto "Integração Sócio-Econômica dos Catadores de Materiais Recicláveis" envolve o Banco Interamericano de Desenvolvimento (BID), o Ministério de Desenvolvimento Social e Luta contra a Pobreza do Brasil (MDS) e o MNCR do Brasil.

$\mathrm{Na}$ cidade de Bogotá $^{17}$ foi possível verificar os grandes desafios enfrentados pelos recicladores, (como se denominam), para serem reconhecidos pelo poder público. Segundo relato de Silvio Ruiz, da Associação de Recicladores de Bogotá (ARB), a Colômbia foi precursora na organização dos catadores, porém não avançou nas parcerias com o poder público. Os catadores vivem situações de embates com o governo e sofrem perseguições políticas.

A crise econômica global e a falta de apoio do poder público fizeram com que as cooperativas voltassem ao estágio de associações pelas dificuldades

\footnotetext{
${ }^{15}$ Fundação AVINA. Relatório Anual 2009- Reciclagem Sustentável. Disponível em: http://www.informeavina2009.org/portugues/reciclaje.sht.

${ }^{16}$ Recursos de U\$7,9 milhões investidos ao longo de quatro anos no desenvolvimento de um modelo de colaboração para a inclusão econômica dos setores de baixa renda a partir de ações de integração social e profissionalização produtiva (Relatório AVINA 2008).

17 Foi realizada visita técnica a duas cooperativas na cidade de Bogotá em setembro de 2010.
} 
em pagar os encargos trabalhistas que recaem sobre as cooperativas e que, segundo Silvio Ruiz, são semelhantes aos de uma empresa privada. Observouse em Bogotá a força de um movimento social que se organiza de forma independente e sem apoio do governo federal diferentemente da forma que ocorre no modelo brasileiro. A privatização dos serviços públicos, dentre eles a coleta seletiva é um obstáculo que só é possível enfrentar com a criação das redes regionais, nacionais e internacionais.

Um dos grandes avanços para os catadores se deu recentemente com a promulgação da Lei Federal 29419, de outubro de 2009, do Peru, que reconheceu o trabalho dos catadores de materiais recicláveis e Ihes outorga a sua formalização e integração aos Sistemas de Gestão de Resíduos Sólidos do país (MNCR, 2010). O país é o primeiro na América Latina a promulgar uma lei que regulamenta a atividade dos catadores.

Em relação aos catadores observa-se que apesar destes significativos avanços, existe ainda, no Brasil, uma grande dependência das organizações de catadores de políticas públicas favoráveis, em todas as esferas de governo, principalmente no nível municipal, responsável pela contratação do serviço e do fortalecimento do MNCR enquanto movimento social (MNCR, 2006; BESEN, 2008; DIAS, 2010). Constata-se que o apoio governamental, privado e do terceiro setor, às organizações de catadores também é necessário e que sem este apoio as organizações não têm condições de se transformarem em empreendimentos sociais.

As ameaças são inúmeras, mas as oportunidades também. Porém é fundamental destacar o crescente acúmulo de capital social, o fortalecimento das redes de apoio nacionais e internacionais, os esforços de capacitação e modernização tecnológica. Destaca-se também a necessidade de aproveitar o momento político favorável para consolidar as políticas públicas e os processos de capacitação e ampliar os espaços de negociação tanto com o estado quanto com a iniciativa privada. Apesar dos projetos que buscam o fortalecimento das 
organizações de catadores, o desafio de incluir mais catadores é enorme. A situação é agravada pela presença de milhares de catadores presentes ainda em lixões, sobrevivendo em condições inaceitáveis do ponto de vista humanitário.

Entende-se que todos os esforços dos movimentos apresentados neste capítulo propiciam um momento favorável, porém ainda frágil para a consolidação do modelo de coleta seletiva no Brasil. Assim, a elaboração e a validação de indicadores de sustentabilidade tanto para a coleta seletiva formal municipal quanto para as organizações de catadores são estratégicas no sentido de fortalecer e consolidar políticas públicas de coleta seletiva com organizações de catadores.

A pesquisa desenvolvida busca nesse sentido contribuir para ampliar e definir consensos sobre o que significa a sustentabilidade tanto para a coleta seletiva quanto para as organizações de catadores na visão de especialistas e de vários atores envolvidos com a gestão da coleta seletiva. 


\section{MARCOS CONCEITUAIS}

O referencial conceitual desta pesquisa é centrado em três temas interdependentes; 1) saúde e sustentabilidade, a partir de seus determinantes sociais (apresentada no Capítulo 2); 2) gestão integrada e sustentável de resíduos; e 3) construção e validação participativa de indicadores de sustentabilidade.

\subsection{GESTÃO INTEGRADA E SUSTENTÁVEL DE RESÍDUOS SÓLIDOS}

A preocupação mundial em relação aos resíduos sólidos domiciliares tem aumentado devido ao crescimento da produção, ao aumento da periculosidade de alguns resíduos, ao gerenciamento inadequado e a falta de áreas para disposição final.

O tema tem se mostrado prioritário desde a Conferência RIO - 92, em escala global, tanto nos países ricos quanto nos mais pobres. O conceito de gestão integrada e sustentável dos resíduos (Integrated Solid Waste Management (ISWM) vem sendo aprimorado e implica numa hierarquia de objetivos. Estes incluem a minimização da geração de resíduos, a redução dos impactos negativo dos resíduos, a maximização da reutilização, da reciclagem e compostagem, a recuperação de energia, a promoção de tratamento e a disposição final de forma ambientalmente segura (AGENDA 21, 1997; KLUNDERT et al., 2001; ADEDIPE et al., 2005). Também inclui a maximização da cobertura dos serviços de limpeza urbana e da coleta seletiva. Ainda não existe consenso se esse conceito de gestão integrada também abarca a 
questão dos catadores, embora utilizado dessa forma por alguns autores. No Brasil se denomina a coleta seletiva em parceria com catadores de: coleta seletiva solidária, coleta seletiva com inclusão social, coleta seletiva com inclusão de catadores e coleta seletiva sustentável.

GÜNTHER e GRIMBERG (2006) sustentam que a gestão integrada, sustentável e participativa é um conceito interdisciplinar e em construção que pode ser entendido a partir de três níveis intimamente relacionados: 1) as etapas da administração: geração, acondicionamento, coleta, transporte, tratamento reaproveitamento de recicláveis e biomassa e disposição final com recuperação energética; 2) a busca da intersetorialidade pela administração pública, articulando as diferentes áreas do governo envolvidas com a temática dos resíduos sólidos, tanto na esfera municipal e regional, quanto nas estaduais e na federal; e 3) o envolvimento de múltiplos agentes sociais em ações coordenadas pelo poder público, buscando a intersetorialidade entre governo, setor privado e a sociedade.

Nesse sentido, o conceito de gestão integrada e sustentável dos resíduos sólidos representa uma abordagem que busca alcançar soluções mais sustentáveis para os problemas relacionados aos resíduos sólidos nas cidades dos países do Sul (KLUNDERT e ANSCHIITZ, 2000; ADEDIPE et al., 2005, GÜNTHER e GRIMBERG, 2006).

O conceito de gestão integrada e sustentável de resíduos sólidos para KLUNDERT et al. (2001) envolve 4 princípios básicos:

a) Equidade: todos os cidadãos têm direito a um sistema adequado de gerenciamento de resíduos por razões ambientais e de saúde;

b) Efetividade: o modelo de gerenciamento dos resíduos deve coletar e destinar de forma adequada os resíduos; 
c) Eficiência: o gerenciamento de todos os resíduos deve maximizar os benefícios, minimizar custos e otimizar o uso de recursos naturais, levando em conta a equidade, efetividade e sustentabilidade;

d) Sustentabilidade: o sistema de gerenciamento de resíduos deve ser adaptado à realidade local e factível nas perspectivas técnica, ambiental, social, econômica e, financeira e institucional.

Uma das mudanças significativas que ocorre no setor de resíduos sólidos no Brasil e em alguns países em desenvolvimento é o estabelecimento de maior integração entre os setores formais e informais ligados à cadeia de resíduos. Em termos globais ocorre a adoção de tecnologias mais adequadas de gerenciamento de resíduos sólidos urbanos (UNEP/UN-DESA, 2005). Dentre elas, destacam-se as tecnologias sociais definidas pelo Ministério de Ciência e Tecnologia (MCT) em 2005, como "um conjunto de produtos, técnicas ou metodologias transformadoras, desenvolvidos na interação com a população e apropriados por ela, e que representam efetivas soluções de transformação".

A prática de catação autônoma de materiais recicláveis há muito desenvolvida de forma desorganizada nas ruas das cidades brasileiras tem sido objeto de inserção nas políticas de governo. Muitas administrações municipais, em países em desenvolvimento, têm investido em sistemas de coleta seletiva em parceria com organizações de catadores, de acordo com modelos desenvolvidos a partir de suas diferentes dinâmicas locais (MEDINA, 2006; SHEINBERG et al., 2006). As estratégias incluem a legalização de atividades dos catadores, o estimulo à formação de cooperativas, contratos para atividades de coleta e reciclagem, além de estabelecimento de parcerias público-privado entre autoridades locais e organizações de catadores (UNEP/UN-DESA, 2005).

A literatura sobre pesquisa no tema da gestão de resíduos sólidos urbanos permite observar que esta se desenvolve a partir de dois focos 
analíticos (BESEN e RIBEIRO, 2008): uma primeira referente às reformas do setor público, incluindo os processos de privatização (RONDINELLI e IACONO, 1996; SAMSON, 2007) e a segunda relacionada com a problemática da sustentabilidade no contexto urbano, na qual também se inclui as questões de saúde e bem estar humano (LARDINOIS e KLUNDERT, 1995; GRAFAKOS e BAUD, 1999; ADEDIPE et al., 2005).

O primeiro enfoque destaca o papel do mercado, o impacto do ajuste estrutural na redução do tamanho do estado, os processos de privatização dos serviços públicos e o gerenciamento dos serviços. Na literatura sobre a privatização dos serviços de gerenciamento de resíduos sólidos, a análise das parcerias público-privadas tem primordial importância e abrange as atividades de coleta, transporte, tratamento e disposição final. Os estudos enfocam a cobertura dos serviços públicos e sugerem diferentes formas de privatização com vistas a aumentar a eficiência e efetividade dos serviços. Dá-se pouca atenção ao potencial das pequenas escalas, pequenos operadores privados e trabalhadores informais que retiram os resíduos das áreas residenciais.

A privatização implica num arranjo público-privado, no qual o governo mantém certo grau de poder, reduz custos e interferência política (BARTONE et al., 1991; ALI, 1993; FERNANDEZ, 1993; COINTREU-LEVINE, 1994; POST, 1999; BARTONE, 2000, DORVIL, 2007). A ênfase se dá nos grandes contratos para os quais o sistema informal não está qualificado.

$O$ segundo enfoque enfatiza a relação entre sustentabilidade e desenvolvimento, e representa uma fonte relevante de argumentação para a análise de sistemas de gerenciamento de resíduos sólidos, nos países em desenvolvimento. Este enfoque se fortalece a partir da Conferência Rio-92 e decorre do que se convencionou denominar de agenda marrom, com um enfoque predominantemente urbano (SCHUBELER, 1996). Para diversos autores (HARDOY et al., 1992, 2001; MITLIN, 2001), trata-se de um marco conceitual no qual as melhorias no ambiente natural são consideradas 
conjuntamente com melhorias na qualidade de vida dos habitantes das cidades. Os estudos sobre gestão de resíduos sólidos realizados dentro deste marco conceitual, na sua maioria abordam o papel dos diferentes atores para melhorar a qualidade de vida no ambiente urbano (BAUD e POST, 2003) A literatura nesse segundo enfoque enfatiza as possibilidades de reduzir os fluxos de resíduos através de iniciativas de prevenção reutilização e reciclagem (GRAFAKOS e BAUD, 2003). Isto inclui arranjos públicos - privados, entre comunidades e setor privado, e entre agentes privados.

Para KLUNDERT e ANSCHIITZ (2000), a maior lacuna na literatura existente sobre gerenciamento de resíduos sólidos nos países em desenvolvimento é que são raramente investigados em sua totalidade. Isto inclui as áreas de prevenção da geração, reutilização e reciclagem, na mesma proporção que se estuda as atividades do setor público de coleta, transporte e destinação final. São quase inexistentes as análises que combinam aspectos ambientais e socioeconômicos.

As pesquisas acadêmicas realizadas sobre os temas catadores de materiais recicláveis e sistemas informais de gerenciamento de resíduos sólidos vêm se ampliando no Brasil e em outros países. Indonésia, Egito, Colômbia, Filipinas, México e Brasil são os países que apresentam maior produção sobre o tema (BIRBECK, 1978; CASTILLO, 1990; GONZALEZ et al., 1993; MORENO et al., 1999; RODRIGUEZ, 2002; NAS e JAFFE, 2004; MEDINA, 1997, 2006). $\mathrm{Na}$ perspectiva histórica e comparativa destaca-se a importância de quatro fatores: o uso e a apropriação de tecnologia em sistemas de coleta seletiva realizada por catadores, a experiência sociocultural dos catadores, avanços na gestão integrada e o contexto sócio político (SCHÜBELER, 1996).

Segundo ALENCAR (2008), o Manual de Gerenciamento Integrado de Resíduos Sólidos, publicado pelo Instituto de Pesquisas Tecnológicas (IPT) e CEMPRE com edição inicial em 1995, foi o primeiro livro técnico no Brasil a abordar a questão dos catadores. Este autor destaca que na literatura técnica 
específica da área de resíduos sólidos identificam-se poucos autores, cujas preocupações superam 0 enfoque meramente técnico-operacional das abordagens tradicionais relacionadas aos resíduos sólidos dentre eles, COINTREAU-LEVINE (1994), TCHOBANOUGLOS (1993), THEISEN e VIGIL (1993), CALDERONI (1998), e EIGENHEER (2003).

De acordo com DIAS (2009) a literatura mais recente sobre o tema parece apontar na direção de esforços mais integrativos em direção a uma maior teorização sobre os catadores e sua organização. Especialistas da área e redes diversas vêm buscando integrar estudos empíricos e/ou experiências de ativistas a um arcabouço teórico e contribuir com o campo de estudo acadêmico (SCHEINBERG et al., 2006; MEDINA, 2007; SAMSON, 2009).

No Brasil, as transformações do papel do Estado, notadamente desde a década de 80 , têm provocado mudanças na forma de relacionamento entre Estado e Sociedade. A sociedade civil vem desenvolvendo e multiplicando práticas que reforçam a autonomia e a legitimidade de atores sociais. O papel das instituições da sociedade civil nas suas diversas práticas tem se assentado na valorização das parcerias e nas propostas de ação e intervenção baseadas no tripé: cooperação, solidariedade e participação (DAGNINO, 2002; JACOBI, 2000). Desde 1989 multiplicam-se no Brasil as experiências de gestão integrada e sustentável de resíduos sólidos, por meio da coleta seletiva municipal em parceria com catadores de materiais recicláveis, organizados em associações e cooperativas. A coleta seletiva operada por organizações de catadores rompe com a lógica de privatização tradicional dos serviços na medida em que incorpora gradativamente um perfil de inclusão social e geração de renda para os setores mais carentes e excluídos do acesso aos mercados formais de trabalho (MARTINS, 2004; BESEN, 2006; DEMAJOROVIC et al., 2006; MEDINA, 2006; SAMSON, 2007; DIAS, 2009).

Vários autores (GRAFAKOS e BAUD, 2001; LARDINOIS e KLUNDERT, 1995; LARDINOIS, 1996) identificaram os principais tipos de parcerias nos 
sistemas de gerenciamento de resíduos sólidos e enfatizam a participação dos atores relevantes (stakeholders). Para tanto realizaram uma revisão qualitativa das contribuições das parcerias nos aspectos da sustentabilidade sócioeconômica e ambiental, no intuito de reforçar a importância do conceito de gerenciamento integrado de resíduos sólidos. Destacam seis aspectos da sustentabilidade: tecnológico, ambiental, econômico-financeiro, social, cultural e político-institucional, numa perspectiva integrada que permite a articulação de atores e o desenvolvimento de indicadores.

\subsection{INDICADORES DE SUSTENTABILIDADE: CONSTRUÇÃO E VALIDAÇÃO PARTICIPATIVA}

Ao longo das últimas décadas a elaboração e aplicação de indicadores se consagraram enquanto ferramenta de análise e interpretação de uma dada realidade. Vários autores (OTT, 1998; CORVALAN et al., 2000; BELLEN, 2005; SICHE et al., 2007; GUIMARÃES e FEICHAS, 2009) alertam para a importância de se definir com clareza o que se quer medir, a forma de coletar informações existentes que auxiliem na tomada de decisão política apropriada e sobre a dificuldade de adequar o uso de indicadores em nível nacional para situações locais específicas.

O termo indicador é definido pela Organization for Economic Cooperation and Development (OCDE) como um parâmetro ou valor derivado de parâmetros que aponta, fornece informações ou descreve o estado de um fenômeno, ambiente ou área, cujo significado excede aquele diretamente associado ao valor do parâmetro (OCDE, 1993). Os indicadores têm a função de síntese e são desenvolvidos para propostas específicas. É consenso entre os especialistas que para a sua efetividade os indicadores devem ser simples, alimentados com dados disponíveis e que permitam uma rápida avaliação. 
Segundo SICHE et al. (2007), existem conceitos diferentes e muitas interpretações sobre índices e indicadores o que cria certa confusão sobre os seus significados. No entanto, os autores consideram que o termo índice é um valor numérico que representa a correta interpretação da realidade de um sistema simples ou complexo (natural, econômico ou social), utilizando-se em seu cálculo, bases científicas e métodos adequados. $O$ índice pode ser utilizado como instrumento de tomada de decisão e previsão, e é considerado um nível superior da junção de um grupo de indicadores ou variáveis. Com relação ao termo indicador os autores argumentam que consiste em um "parâmetro selecionado e considerado isoladamente ou em combinação com outros para refletir sobre as condições do sistema em análise.

Os indicadores e índices são instrumentos que dão suporte à tomada de decisão, e seu uso pressupõe a superação ou mitigação de problemas por eles identificados (MONTIBELLER, 2010). Por isso têm um importante papel na construção e direcionamento das políticas públicas e das políticas e práticas do setor privado. Enquanto instrumentos efetivos de gestão ou de monitoramento são úteis para estabelecer metas e promover avanços, tendo em vista objetivos definidos, como também para acompanhar, monitorar e avaliar resultados de ações e programas, mediante o planejamento mais adequado e a intervenção dirigida sobre a realidade.

Alguns autores vão além e consideram importante definir o problema e os indicadores relevantes em conjunto com as partes interessadas (CORVALAN et al., 2000; BALLESTER et al., 2006; GUIMARÃES et al., 2009).

As práticas socioambientais de caráter colaborativo e participativo, tais como a coleta seletiva de resíduos urbanos têm se revelado como veículo importante na construção de uma nova cultura de diálogo e participação (JACOBI, 2000; ARNSTEIN, 2002). Isto abre espaço para a construção de eixos interdisciplinares em torno dos quais se tece uma nova cultura de gestão compartilhada, um espaço possível de diálogos horizontalizados, de 
aprendizagem do exercício da democracia participativa, mediando experiências de diferentes sujeitos/atores sociais locais na construção de projetos de coletivos (JACOBI et al., 2006).

Esse "fazer coletivo" configura-se em importantes estratégias que englobam um conjunto de atores e práticas. Estes podem ser elementos inovadores para a construção de acordos na gestão compartilhada dos resíduos sólidos. Também fomenta a compreensão e o acolhimento de novos paradigmas, além de abrir possibilidades de novas escolhas do poder público e da sociedade numa perspectiva de avanço rumo à sustentabilidade socioambiental (JACOBI et al., 2006)

O aperfeiçoamento das políticas públicas tem um importante componente no papel do poder público municipal, das múltiplas instituições e organizações sociais, dos sistemas de informação e comunicação e dos valores adotados pela sociedade (GUIMARÃES, 2001; JANUZZI, 2002; 2006).

A construção coletiva facilita uma aprendizagem coletiva, e se sustenta, no caso desta pesquisa, no trabalho de um grupo que tem um objetivo comum, a melhoria e sustentabilidade da coleta seletiva com inclusão social de catadores de materiais recicláveis. Este trabalho promove um diálogo reflexivo que permite selecionar e construir os indicadores de sustentabilidade e adaptálos às escolhas, aspirações e projetos dos atores envolvidos o que implica em que a proposta seja participativa e possa influenciar na definição dos indicadores, e assim garantir a legitimidade, eficiência e transparência (GUIMARÃES e FEICHAS, 2009; BELLEN, 2005).

Nesse sentido o trabalho desenvolvido se apoiou numa metodologia colaborativa e participativa para promover o diálogo entre os atores envolvidos na gestão, tanto na definição de sustentabilidade da coleta seletiva e de organizações de catadores quanto na seleção e avaliação dos indicadores que melhor as representam. Isto inclui o aprendizado dos atores e como lidam com a construção de consensos e a busca de sinergia de negociações. Desta forma 
as posições coletivas e individuais, tanto na utilização da técnica Delphi quanto em oficinas presenciais são colocadas em negociação, de preferência numa perspectiva de ganhos mútuos, e em processos de aprendizagem colaborativa.

Muitas são as ferramentas e metodologias de negociação existentes e que podem ser combinadas com outras metodologias. A negociação é uma importante estratégia para construção de decisões conjuntas.

A opção pela técnica Delphi para a validação de indicadores de sustentabilidade pressupõe a participação voluntária de especialistas que manifestam sua avaliação individual, e tem a oportunidade de rever sua visão a partir do resultado da avaliação do grupo nas diversas rodadas que o método possibilita, e nesta pesquisa se deu em duas rodadas. O processo de interação numa sucessão de negociações contínuas voltado para ampliação de consensos permite uma aproximação de conceitos, concepção e priorização de um conjunto de indicadores estratégicos. Na visão coletiva e colaborativa representam a sustentabilidade da gestão, enquanto diagnóstico da situação atual e de alternativas para definir um plano de ação na gestão da coleta seletiva e das organizações.

Além da aplicação da técnica Delphi, a opção pela realização de oficinas regionais e específicas numa perspectiva participativa; possibilitou 0 envolvimento num processo dinâmico de diferentes atores e diversas visões, a partir de diferentes lócus: acadêmico, esferas de governo, empresarial, movimento social e ONGs. A participação de uma comunidade de avaliadores estendida é um dos elementos fundamentais para a seqüência de negociações entre os múltiplos atores e para a governança (FUNTOWICZ e STRAND, 2007). Questões técnicas permeiam a tomada de decisão e os conflitos cognitivos entre atores leigos e peritos nem sempre são compreensíveis para todos (GIDDENS, 1992). Estas implicam em diferentes leituras, e estabelecem diversos pontos de vista, e isto demanda um espaço de negociação. A reflexão 
conjunta sobre a prática entre todos os atores envolvidos permite o aprendizado e intervenção conjunta, através de um processo negociado (GRANJA, 2009).

Retomando a questão dos indicadores observa-se que os estudos sobre sustentabilidade defrontam-se com 0 desafio freqüente de lidar com informações complexas e não sistematizadas.

No final da década de 80 , surgiram as primeiras propostas de construção dos índices ambientais.

Dentre as dificuldades metodológicas comuns na construção de indicadores ambientais destacam-se a formulação conceitual apropriada, a tradução operacional em variáveis, a obtenção de dados fidedignos e o seu tratamento estatístico adequado (ESTY e PORTER, 2002; IBGE, 2004; ESI, 2006; TAYRA e RIBEIRO, 2006).

De acordo com PINTER et al. (2005) no aspecto metodológico, até o ano de 2005, permaneciam as incertezas e debates sobre quais os indicadores adequados e como medi-los (como relacionar indicadores específicos a objetivos associados com temporalidade e limiar). Os autores afirmavam que a comparabilidade dos sistemas de indicadores permanecia limitada por diversos marcos de referência. Embora os índices agregados parecessem atraentes para a comunicação com os cidadãos, requeriam uma alta qualidade de dados para uma comparação consistente, isto somado a um consenso político sobre o peso (ponderação) do indicador e a dificuldade de obtenção em escala internacional, nacional e sub-nacional.

Nas últimas décadas, na busca da mensuração da sustentabilidade, e mediante o reconhecimento do importante papel de sua medição, houve uma profusão de indicadores e índices de sustentabilidade ambientais e socioambientais, em âmbito local, regional e global (ESTY e PORTER, 2002; BELLEN, 2005; TAYRA e RIBEIRO, 2006; VEIGA, 2009). TAYRA e RIBEIRO (2006) observam que, até o ano de 2006, centenas de experiências de construção de indicadores de sustentabilidade com diferentes modelos e 
abordagens eram conduzidas em âmbito global. No ano de 2004, 624 experiências espontâneas eram relatadas no site da International Institute for Sustainable Development (TAYRA e RIBEIRO, 2006).

No entanto segundo VEIGA (2009), até 2009, em relação aos indicadores socioambientais "não tem havido sequer aquele mínimo de convergência que seria necessário para que houvesse legitimação de algum (ou alguns) deles".

Ao abordar o que denomina de "nevoeiro" na área de indicadores de sustentabilidade, e enveredar pelos critérios para uma taxonomia, VEIGA (2009) destaca duas características: a agregação e a precificação e observa.

\begin{abstract}
"Por um lado, são bem distintas abordagens que se contentam com "sistemas de indicadores" ("dashboards", CGSDI, 2002), e aquelas que se propõem a agregá-los em algum tipo de índice sintético. Por outro, também há uma verdadeira muralha entre os indicadores que assumem 0 desafio (ou rejeitam a necessidade) de se atribuir valores monetários aos bens e serviços ambientais. Além disso, outras diferenciações decorrentes de escolhas de dimensões, variáveis, e métodos de agregação, multiplicam o número de categorias possíveis. Mas parece óbvio que seria errado inverter esta ordem hierárquica, e enveredar por uma prévia classificação dos indicadores por tais escolhas, para só depois considerar se eles são ou não monetários e/ou sintéticos. As revisões que não estabelecem esses dois "divisores de águas" acabam contribuindo para que o "nevoeiro" fique ainda mais espesso. Ver, por exemplo, OECD (2001, 2003)".
\end{abstract}

No que se refere aos indicadores de sustentabilidade, em âmbito global, VEIGA (2010, p. 6) sustenta que o "Report by the Comission on Measurement of Economic Performance and Social Progress" (STIGLITZ et al., 2009), denominado Relatório Stiglitz, representa um novo marco e um ponto de partida na concepção de como medir a sustentabilidade, ao definir a necessidade de 
medir separadamente: desempenho econômico, qualidade de vida (bem estar) e a sustentabilidade do desenvolvimento.

Para VEIGA (2010), o relatório ainda orienta no sentido de que:

a) O PIB deve ser substituído por uma medida bem precisa de renda domiciliar disponível, e não de produtos;

b) A qualidade de vida deve ser medida por um índice composto que incorpore as recentes descobertas desse novo ramo, o que inclui a economia da felicidade;

c) A sustentabilidade precisa de um pequeno grupo de indicadores físicos que substituam a tendência crescente de atribuir valores aos serviços ambientais.

De acordo com JANUZZI (2006) existem três propriedades desejáveis a um indicador: relevância social, validade de constructo e confiabilidade. Vários autores apontam um conjunto de propriedades básicas que devem estar incorporadas a um indicador tais como: acessibilidade de compreensão, possibilidade de quantificação estatística e, capacidade de expressar eficientemente o fenômeno em observação (CASTRO-BONAÑO, 2002; SICHE et al., 2007; MIRANDA e TEIXEIRA, 2010).

MEADOWS (1998) alertou sobre sete riscos possíveis no processo de escolha e utilização de indicadores de sustentabilidade:

a) Depender de falsos modelos - selecionar os indicadores baseados em relações de causa e efeito que não são reais;

b) Desviar a atenção da experiência direta - utilizar números para mudar a percepção das pessoas; 
c) Agregação excessiva - agregar muitas informações combinadas pode comprometer a mensagem tornando-a indecifrável;

d) Excesso de confiança - os indicadores podem passar a impressão de que controlam uma dada situação, embora apenas monitorem a sua ocorrência;

e) Falsificação de dados - minimizar o impacto de informações negativas por meio de alterações deliberadas ou mascaramento de dados obtidos pelo indicador;

f) Incompletude - os indicadores não podem ser interpretados como a realidade de certas situações reais, pois não incorporam uma série de detalhes e particularidades;

g) Medir o mensurável, e não o importante - dificuldades operacionais podem gerar o risco de se medir algum fenômeno relacionado, e não o necessário.

MILANEZ (2002), baseando-se em vários autores afirma que os indicadores precisam fazer ligações ou relações entre os diferentes elementos das distintas dimensões da sustentabilidade (abrangência das dimensões). Na medida do possível, deve-se buscar concentrar o maior número de informações em um indicador. Isto não requer apenas o conhecimento do fenômeno, ou instituição, em questão; mas o cumprimento de alguns procedimentos para sua escolha e validação.

Uma forma de validação de indicadores, denominada de 3S, é proposta por BALLESTER et al. (2006). Esta busca medir os impactos socioambientais, mas pode ser utilizada para outros tipos de indicadores. Propõe avaliar a adequação do indicador em três estágios complementares: validação pelos proponentes do indicador, validação cientifica e validação social. Nesse método, a avaliação de indicadores é realizada a partir da atribuição de notas, com a posterior atribuição de pesos e agregação. Os autores recomendam também que o processo seja conduzido em três fases: 1) identificar indicadores que possam 
atender as necessidades, 2) avaliar a possibilidade de usá-los em uma situação específica e, 3) ajustá-los ou definir novos indicadores. Na última fase, o procedimento em geral provoca uma lacuna de validação apontada pelo Global Reporting Initiative, 2000, e agravada nos casos em que não existe participação social para dar suporte à construção de consensos e transparência. A técnica Delphi é utilizada com os dois grupos, científico e social, até atingir o máximo consenso.

\subsubsection{Indicadores de resíduos sólidos urbanos}

Existe uma ampla gama de indicadores, associados à gestão de resíduos sólidos urbanos - RSU utilizados em âmbito nacional e internacional. MILANEZ, (2002, págs. 85, 86, 87) identificou na literatura internacional, 37 indicadores utilizados em vários países OCDE, Alemanha, Áustria, EUA, Noruega, Canadá, Reino Unido, Europa, dentre outros, para mensurar a gestão dos resíduos sólidos urbanos. Observou a dificuldade de categorizá-los em função das diferentes nomenclaturas e formas de medição. Também destacou a diferença de objetivos entre indicadores de sustentabilidade e os de gerenciamento. Os indicadores de sustentabilidade, construídos principalmente em países industrializados, tem um enfoque mais voltado para a dimensão ambiental dos resíduos. Por outro lado, os indicadores de gerenciamento abordam também questões da dimensão econômica e social. Este autor ainda argumenta que os índices encontrados apresentam algumas restrições de uso, principalmente devido à falta de rigor na sua elaboração, à arbitrariedade na definição de alguns parâmetros e à grande quantidade de informações que tentam sintetizar.

Os indicadores de sustentabilidade voltados aos resíduos sólidos têm sido utilizados em conjunto com outros indicadores, como é o caso da Pegada 
Ecológica (REES e WACKERNAGEL, 1996), da Pegada de Carbono $^{18}$, e no âmbito da sustentabilidade urbana (SUSTAINABLE SEATTLE, 1998; EUROPEAN FOUNDATION, 1998; XARXA DE MUNICIPIS, 2000; MARTINEZ e CARPI, 2006; FRAGKOU, 2009).

No Brasil são utilizados vários indicadores oficiais de resíduos sólidos em várias pesquisas de órgãos de governo: Censo Demográfico - IBGE, Pesquisa Nacional de Saneamento Básico (PNSB), Pesquisa Nacional de Amostra por Domicilio (PNAD), Indicadores de Desenvolvimento Sustentável (IDS) e Sistema Nacional de Informação sobre Saneamento (SNIS), do Ministério das Cidades. A maioria destas pesquisas inclui indicadores relacionados à coleta seletiva.

Destaca-se o Diagnóstico do Manejo de Resíduos Sólidos Urbanos do SNIS que, desde o ano de 2002 (SNIS, 2010) realiza a coleta dados institucionais, operacionais e econômicos sobre a prestação de serviços de limpeza urbana, em amostras representativas de municípios brasileiros. A participação dos municípios na pesquisa é voluntária. No ano de 2008, de 527 municípios convidados a participarem, 372 responderam aos questionários.

Organizações empresariais também realizam pesquisas. O Compromisso Empresarial para a Reciclagem (CEMPRE) avalia e monitora a coleta seletiva no país, desde o ano de 1994, por meio da Pesquisa Ciclosoft. A Associação Brasileira de Empresas de Limpeza Pública e Resíduos Especiais (ABRELPE) elabora anualmente, desde 2003 o Panorama de Resíduos Sólidos no Brasil.

As prefeituras municipais do país, em geral, utilizam alguns destes indicadores para a gestão de resíduos sólidos e monitoramento da coleta seletiva em seu âmbito de abrangência.

Em 1989, a PNSB realizou o primeiro levantamento oficial que identificou 58 municípios com coleta seletiva no país. O último levantamento da PNSB, em 2008, identificou quase 1.000 iniciativas. Entretanto, suas escalas que podem

${ }^{18}$ Carbon footprint of nations. Disponível em: www.carbonfootprintofnations.com.br. 
variar desde um bairro ou apenas a escolas até abranger o município como um todo não foram especificadas (IBGE, 2010).

$\mathrm{Na}$ pesquisa de Indicadores de Desenvolvimento Sustentável (IBGE, 2002, 2004; 2010) os indicadores sobre coleta seletiva e reciclagem são abordados na sua dimensão econômica. VEIGA (2009) considera que estes indicadores optaram por sistemas denominados "dashboards", como o GeoBrasil, (SANTOS e CÂMARA, 2002), iniciativa que no seu entender "deve ser muito valorizada, mas, sobretudo como base de dados para a elaboração de indicadores com algum nível de agregação ou de síntese". A metodologia dos "dashboards" inova ao apresentar um novo procedimento para monitorar o desempenho de uma organização. Pode ser visto como um instrumento para a comunicação dos principais indicadores, resultados e desempenho. O "dashboard" é um painel de informação, um instrumento de gestão para o monitoramento, que contribui no processo decisório.

No Brasil, destacam-se alguns avanços em relação à formulação de indicadores para a coleta seletiva.

BRINGHENTI (2004), a partir de pesquisa de indicadores de coleta seletiva no país definiu um grupo de indicadores de referência para o planejamento e a avaliação de desempenho de programas de coleta seletiva. De um grupo de 25 indicadores selecionados para o processo de validação mediante testes estatísticos, foram validados seis indicadores de referência: 1) Cobertura de atendimento do programa (hab.), 2) Índice de Recuperação de Materiais Recicláveis - TRMR (\%); 3) Quantidade mensal coletada seletivamente ( $t /$ mês), 4) Custo de triagem ( $R \$ / t)$, 5) Quantidade de itens de materiais recicláveis comercializados (un.); e, 6) Custo total do programa ( $R \$)$.

LIMA (2006) selecionou e aplicou 23 indicadores à coleta seletiva do município de Londrina. Utilizou cinco categorias para classificar os indicadores: 1) Indicadores gerais (3); 2) indicadores de aceitação pública (2); 3) indicadores 
operacionais (14); 4) Indicadores de despesa do setor público (2); e 5) Indicadores de custo (1).

Em 2008, em atendimento à Política de Resíduos Sólidos do Estado de São Paulo, Lei estadual № 12.300/2006, a Secretaria de Estado do Meio Ambiente de São Paulo (SMA) desenvolveu dois índices: a) Índice de Gestão de Resíduos Sólidos (IGR), e b) Índice de coleta seletiva- ICS (SECRETARIA DE ESTADO DE MEIO AMBIENTE DE SÃO PAULO, 2010). O IGR é um índice composto por indicadores de resíduos sólidos, utilizado para avaliar os instrumentos de política e suas etapas como a coleta, triagem, tratamento e disposição final tratamento e disposição final. Ao avaliar a gestão dos resíduos nos municípios paulistas a SMA pretende subsidiar a proposição e implementação de políticas públicas estaduais. Para a construção do índice, a seleção dos indicadores foi baseada em: a) análise de textos técnicos específicos sobre o tema; b) listagem de indicadores recomendados na bibliografia específica; e c) análise dos indicadores já desenvolvidos pela Secretaria de Estado do Meio Ambiente-SMA e pela Companhia de Tecnologia de Saneamento Ambiental (CETESB), considerando-se também a disponibilidade dos dados. Os indicadores foram subdivididos em quatro áreas temáticas: 1) instrumentos para a política de resíduos sólidos;2) programas ou ações municipais; 3) coleta e triagem; e 4) tratamento e disposição.

A cada um dos indicadores foram atribuídos pesos, cuja somatória, transformada em um número de 0 a 10, resulta no valor de um índice, denominado Índice de Qualidade de Gestão de Resíduos Sólidos - IQG, para cada município paulista ${ }^{19}$.

O cálculo do Índice de Gestão de Resíduos Sólidos (IGR) foi realizado ponderando-se o valor do IQG e do ICS, e considerando-se ainda os dois índices já aplicados no Inventário Estadual de Resíduos Domiciliares, editado

\footnotetext{
${ }^{19}$ A coleta de dados para teste do IGR foi realizada em 2009, por meio de questionário estruturado, enviado aos 645 municípios do Estado de São Paulo pela Fundação Sistema Estadual de Análise de Dados- SEADE, para a Pesquisa Municipal Unificada.
} 
anualmente pela CETESB, desde 1997: Índice de Qualidade de Aterro de Resíduos (IQR) e Índice de Qualidade da Compostagem (IQC) de acordo com a fórmula:

$I G R=0,4^{\star} I Q G+0,2{ }^{\star} I C S+0,35^{\star} I Q R+0,05^{\star} I Q C$, onde:

IQG - Índice de Qualidade de Gestão de Resíduos Sólidos;

ICS - Índice de Coleta Seletiva (Anexo 1);

IQR - Índice de Qualidade de Aterro de Resíduos;

IQC- Índice de Qualidade de Usinas de Compostagem que são divulgados anualmente no Inventário Estadual de Resíduos Sólidos Domiciliares pela CETESB.

Para CAPELINI et al. (2009), a CETESB diminui o nível de subjetivismo e possibilita o estabelecimento de comparações de maior significância ao adotar a metodologia, na qual realiza uma visita técnica a cada uma das unidades de disposição final existente no município e aplica um formulário padronizado para a determinação do IQR. Resulta da aplicação destes indicadores que a gestão municipal de resíduos sólidos, de acordo com sua nota do IGR pode ser considerada eficiente, mediana e ineficiente.

DEUS et al. (2004) desenvolveram e aplicaram, em quatro regiões do Estado do Rio Grande do Sul, um índice de impacto dos resíduos sólidos urbanos na saúde pública (IIRSP), considerando todos os indicadores (variáveis) que direta ou indiretamente poderiam causar ou provocar danos à saúde humana e animal. A metodologia para a padronização dos indicadores foi baseada no método da normalização (OTT, 1978). O índice foi formado por oito indicadores: 1) Déficit de coleta; 2) Déficit de tratamento e disposição final; 3) Cisticercose; 4) Leptospirose; 5) Teníase; 6) Toxoplasmose; 7) Triquinose; e 8) Orçamento destinado aos serviços de limpeza urbana. Segundo os autores, o 
índice ajudou a espelhar a relação existente entre as características das comunidades regionais relacionadas aos resíduos sólidos e à saúde pública e serviram aos municípios para preencher lacunas de dados. No entanto, alertam para o fato de que os indicadores de doenças representam estatisticamente a maior fração do índice, e ainda sobre a necessidade de realizar estudos epidemiológicos mais aprofundados que possibilitem separar estatisticamente os efeitos da ocorrência de doenças por outras fontes concorrentes aos resíduos sólidos urbanos.

CAMPANI et al. (2009) desenvolveram seis indicadores socioambientais para a coleta seletiva e aplicaram quatro deles à coleta seletiva da cidade de São Leopoldo (RS):

a) Indicador econômico que consiste em um balanço envolvendo todos os custos do programa, a economia resultante da não disposição dos resíduos nos aterros e a renda gerada com a venda do material reciclável;

b) Indicador social que levanta a escolaridade dos filhos dos membros das organizações de catadores. $O$ indicador inclui nível de ensino e situação escolar;

c) Indicador ambiental que estima a economia de energia resultante da reciclagem a partir do cálculo da diferença da energia consumida na produção de material virgem e da produção utilizando material reciclado;

d) Indicador de qualidade fornece a visão da população sobre o programa de coleta seletiva.

O Índice gerencial (e) - geração de resíduos per capita nos diferentes setores da sociedade e o Indicador de saúde (f) - Quadro geral da saúde dos trabalhadores das organizações (baseado na quantidade de abstenções por 
doenças/lesões resultantes da triagem de resíduos correlacionados com dados referentes a doenças em geral e com as ocasionadas pelo consumo de drogas) não foram aplicados.

Os autores acompanharam durante seis meses os quatro indicadores aplicados e concluíram que estes atingiram o objetivo de apoiar os gestores no gerenciamento da coleta seletiva.

\subsubsection{Indicadores de organizações de catadores}

Ao longo dos últimos anos, cresce a quantidade de estudos $\mathrm{e}$ diagnósticos acadêmicos e não acadêmicos, sobre as organizações de catadores, alguns sobre conjuntos de cooperativas e outros sobre cooperativas específicas. Estes estudos, quando não acadêmicos, em geral, estão atrelados a projetos de financiamentos não reembolsáveis, e se baseiam em indicadores referentes às áreas de gestão das cooperativas, perfil socioeconômico dos membros, a exemplo do diagnóstico da Central de Cooperativas do Distrito Federal - CENTCOOP-DF (2008). Este estudo abrangeu 14 organizações e utilizou um grande número de indicadores para avaliar as seguintes áreas: 1) Impactos ambientais provocados pela implantação e operação das cooperativas, 2) Formato jurídico e regularidade institucional, 3) Situação organizacional e instrumentos de decisão, 4) Órgãos de direção das organizações e tempo de mandato da direção atual, 5) Organização do trabalho, divisão da renda e controles adotados, 6) Sistema de organização do trabalho - coleta, triagem e comercialização, 7) Sistema de remuneração do trabalho, produtividade e renda dos catadores, 8) Produção e comercialização, 9) Veículos utilizados na coleta, distâncias, 10) Estimativa das quantidades de materiais comercializados por mês (em toneladas) e 11) Estimativa das quantidades de materiais comercializados por mês (em \%). 
Ainda com relação aos indicadores de organizações de catadores, identificou-se o estudo "Análise do custo de geração de postos de trabalho na economia urbana para o segmento dos catadores de materiais recicláveis" desenvolvido com o objetivo de subsidiar programa do governo federal para criação de milhares de postos de trabalho em organizações de catadores (MNCR, 2006). Este enfocou o trabalho das cooperativas e utilizou três indicadores de eficiência: física, econômica e de mercado: 1) Eficiência física ou produtividade média da produção física per capita, por cooperado, medida em $\mathrm{kg} /$ mês, 2) Eficiência econômica ou retorno bruto médio, calculado pelo valor comercializado da produção per capita, ou seja, por cooperado, medido em $\mathrm{R} \$$ / mês e 3) Eficiência de mercado, que representa a "capacidade da cooperativa em colocar seus produtos recicláveis de forma vantajosa no mercado. A eficiência de mercado é medida por meio da razão entre os índices de eficiência econômica e os índices de eficiência física.

$O$ único estudo acadêmico identificado nessa pesquisa e que enfoca indicadores de sustentabilidade voltados às organizações de catadores é a Pesquisa COSELIX (RIBEIRO et al., 2009), cujos indicadores desenvolvidos encontram-se no Quadro 4.

O conjunto de 12 indicadores construídos e suas respectivas tendências à sustentabilidade (alta, média e baixa) possibilitaram desenvolver uma matriz de sustentabilidade (Quadro 6), aplicar os indicadores em 32 organizações da RMSP e comparar o desempenho.

\subsubsection{Indicadores de sustentabilidade de resíduos urbanos}

No que se refere à elaboração de indicadores de sustentabilidade voltados à gestão de resíduos sólidos no Brasil, MILANEZ (2002) selecionou indicadores de sustentabilidade para resíduos sólidos urbanos baseando-se em 
uma sistematização detalhada da literatura internacional sobre critérios para seleção de indicadores existentes e reconhecidos, baseada em vários autores (WARREN, 1997; TYLER NORRIS ASSOC., 1997; MEADOWS, 1998; DOYLE et al., 1997; BOSSEL, 1999). Identificou 23 critérios, dos quais selecionou 14: 1) Acessibilidade dos dados; 2) Clareza na comunicação; 3) Relevância; 4) Abrangências das dimensões; 5) Amplitude geográfica adequada; 6) Padronização; 7) Preditividade; 8) Pró-atividade; 9) Sensibilidade temporal; 10) Facilidade para definição de metas; 11) Coerência com a realidade local; 12) Consistência científica; 13) Confiabilidade da fonte; e 14) Capacidade de síntese. Utilizou 11 princípios na construção do conjunto de indicadores. Estabeleceu ainda três tendências à sustentabilidade - muito desfavorável, desfavorável e favorável. No caso de situações não quantificáveis, ou em que a medição poderia ser dispendiosa, utilizou um indicador binário: acontece situação e não acontece situação.

Os indicadores foram aplicados na cidade de Jaboticabal (SP) e o autor concluiu que a utilização conjunta de princípios de sustentabilidade específicos e de critérios de avaliação, na escolha de indicadores de sustentabilidade é pertinente e resulta em um conjunto bastante satisfatório de indicadores. Também concluiu que o sistema de indicadores permitiu não apenas uma percepção geral da situação da gestão dos RSU, como ajudou na identificação de prioridades e no planejamento das ações a serem tomadas auxiliando, portanto, a tomada de decisão.

No quadro 2 apresentam-se os princípios e indicadores de sustentabilidade da gestão de resíduos sólidos, propostos por MILANEZ (2002). 
Quadro 2- Princípios e indicadores de sustentabilidade de gestão de resíduos sólidos.

\begin{tabular}{|c|c|}
\hline Princípios & Indicadores \\
\hline $\begin{array}{l}\text { 1. Garantia das condições } \\
\text { adequadas de trabalho }\end{array}$ & Quantidade de acidentes ocorridos/ mês \\
\hline 2. Geração de trabalho e renda & $\begin{array}{l}\text { Não foram identificados indicadores } \\
\text { satisfatórios }\end{array}$ \\
\hline 3. Gestão solidária & $\begin{array}{l}\text { Quantidade de reclamações sobre os } \\
\text { serviços de gestão dos RSU/ mês }\end{array}$ \\
\hline $\begin{array}{l}\text { 4. Democratização da } \\
\text { informação }\end{array}$ & $\begin{array}{l}\text { Advertências emitidas pela instituição de } \\
\text { gestão dos RSU }\end{array}$ \\
\hline 5. Universalização dos serviços & $\begin{array}{l}\text { - População atendida pela coleta regular } \\
\text { - População atendida pela coleta seletiva } \\
\text {-Custo da coleta e transporte dos RSU } \\
\text { - Custo do tratamento dos RSU }\end{array}$ \\
\hline $\begin{array}{l}\text { 6. Eficiência econômica da } \\
\text { gestão }\end{array}$ & Custo total do serviço de gestão dos RSU \\
\hline $\begin{array}{l}\text { 7. Internalização pelos } \\
\text { geradores dos custos e } \\
\text { benefícios }\end{array}$ & $\begin{array}{l}\text { Relação entre a verba arrecadada através } \\
\text { das taxas e o custo dos serviços }\end{array}$ \\
\hline 8. Respeito ao contexto local & Não foram identificados indicadores \\
\hline 9. Recuperação da degradação & $\begin{array}{l}\text { Não foram identificados indicadores } \\
\text { satisfatórios }\end{array}$ \\
\hline $\begin{array}{l}\text { 10. Previsão dos impactos } \\
\text { socioambientais }\end{array}$ & $\begin{array}{l}\text { Quantidade total de RSU coletada } \\
\text { Quantidade de RSU depositada em aterro } \\
\text { sanitário }\end{array}$ \\
\hline $\begin{array}{l}\text { 11. Preservação dos recursos } \\
\text { naturais }\end{array}$ & $\begin{array}{l}\text { - Quantidade de resíduos encaminhados } \\
\text { para disposição final } \\
\text { - Quantidade de resíduos coletados } \\
\text { seletivamente } \\
\text { - Quantidade de RSU compostados } \\
\text { - Quantidade de RSU reciclados }\end{array}$ \\
\hline
\end{tabular}

Extraído de: MILANEZ, 2002. 
Dentre as principais vulnerabilidades o autor destacou:

a) Não identificação de indicadores específicos para avaliar o respeito ao contexto local;

b) $O$ indicador de previsão de impactos ambientais dependente da coerência e confiabilidade de documentos;

c) Necessidade do aprimoramento dos indicadores pela incorporação de processos participativos em suas diversas fases: definição dos princípios específicos, ponderação dos critérios de avaliação, pontuação dos indicadores, obtenção e sistematização dos dados.

POLAZ (2008) também trabalhou com a validação de indicadores de sustentabilidade voltados à gestão dos resíduos sólidos urbanos e concluiu que os indicadores selecionados por MILANEZ (2002) se encontravam em consonância com aqueles propostos por outros autores e instituições (GALLOPIN, 1996; XARXA DE MUNICIPIS, 2000; OECD, 2006; BELLEN, 2005). Após a aplicação destes indicadores na cidade de São Carlos-SP, uma das principais conclusões de sua pesquisa foi a de que os indicadores precisam ser ajustados às realidades locais.

\subsubsection{Indicadores de sustentabilidade de coleta seletiva e organizações de catadores}

Em 2005, a pesquisa COSELIX (RIBEIRO et al., 2009) selecionou e formulou 18 indicadores de sustentabilidade específicos de gestão da coleta seletiva, 6 voltados às prefeituras e 12 às organizações de catadores, e respectivas gradações ou tendências à sustentabilidade (QUADRO 4). A Figura 1 apresenta a metodologia desenvolvida nessa pesquisa. A construção dos indicadores foi baseada em estudo de casos realizados em 11 municípios e 32 organizações de catadores parceiras, na RMSP. 
Figura 1 - Metodologia da pesquisa COSELIX

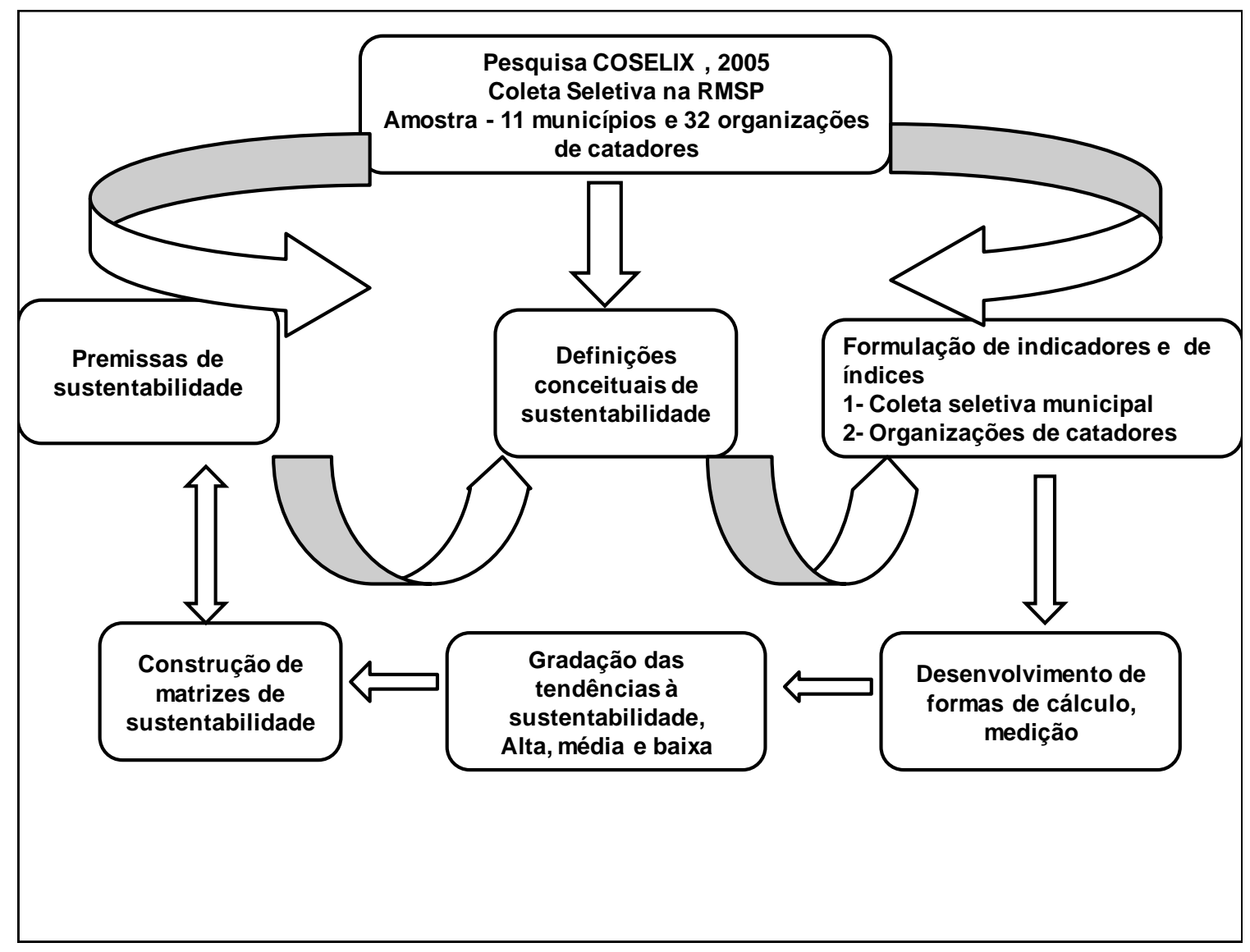

Elaborada pela autora com base em: RIBEIRO et al., 2009, pg. 93.

Também foram definidas as premissas de sustentabilidade para a coleta seletiva municipal executada com organizações de catadores (Quadro 3). É possível verificar uma convergência entre os princípios de MILANEZ (2002) apresentados no Quadro 2 e as premissas de sustentabilidade propostas pela pesquisa COSELIX (Quadro 3) nos aspectos em que se relacionam com a coleta seletiva. 
Quadro 3 - Premissas de sustentabilidade para a coleta seletiva e para as organizações de catadores

\section{Coleta seletiva}

A inserção da coleta seletiva como etapa da Gestão Integrada de Resíduos Sólidos Urbanos no Sistema de Limpeza Urbana do município.

A existência de instrumento legal/jurídico entre as partes envolvidas.

A remuneração pelo serviço prestado pelas organizações proporcional à quantidade de resíduos coletada e triada.

A universalização dos serviços, com qualidade.

A existência de política pública e de mecanismos de incentivo que induzam à autonomia das organizações de catadores.

A existência de Programa de Educação Ambiental e de informação à sociedade, visando ao aumento do grau de adesão à coleta seletiva, com qualidade na segregação dos materiais.

Aumento significativo da quantidade de materiais encaminhados para reciclagem e a redução de resíduos sólidos destinado aos aterros sanitários.

\section{Organizações de Catadores}

A instituição formal da organização e sua inserção na política pública municipal de resíduos sólidos, formalizada por meio de instrumento legal

A existência de infra-estrutura, equipamentos e capacitação para o desempenho das atividades de coleta, segregação e comercialização.

Garantia de renda e benefícios para os membros.

Condições adequadas de higiene, segurança e saúde do trabalhador, nos aspectos de infra-estrutura, equipamentos e conforto ambiental.

A existência de rede de apoio, representada pelas parcerias necessárias à realização das diversas atividades da organização.

Extraído de: RIBEIRO et al., 2009. 
A pesquisa COSELIX também elaborou gradações ou tendências à sustentabilidade (alta, média e baixa) dos indicadores (Quadro 4).

Quadro 4 - Indicadores de sustentabilidade de coleta seletiva e de organizações de catadores e respectivas tendências à sustentabilidade Pesquisa COSELIX, 2005.

Indicadores de sustentabilidade de coleta seletiva municipal

\begin{tabular}{|l|l|l|c|}
\hline \multirow{2}{*}{} & \multicolumn{2}{|c|}{ Tendências à sustentabilidade } \\
\cline { 2 - 4 } & \multicolumn{1}{|c|}{+} & \multicolumn{1}{c|}{+} & \multicolumn{1}{c|}{+ - } \\
\hline $\begin{array}{l}\text { 1. Sustentabilidade } \\
\text { econômica }\end{array}$ & $\begin{array}{l}\text { Existência de } \\
\text { taxa específica }\end{array}$ & $\begin{array}{l}\text { Não existência de } \\
\text { cobrança }\end{array}$ & $\begin{array}{l}\text { Cobrança de } \\
\text { taxa no IPTU }\end{array}$ \\
\hline 2. Marco legal & $\begin{array}{l}\text { Com lei e } \\
\text { convênio }\end{array}$ & $\begin{array}{l}\text { Sem lei nem } \\
\text { convênio }\end{array}$ & $\begin{array}{l}\text { Só lei ou só } \\
\text { convênio }\end{array}$ \\
\hline 3. Parcerias & Duas ou mais & Nenhuma & Uma \\
\hline 4. Cobertura da coleta & $75 \%$ a 100\% & Abaixo de 30\% & $31 \%$ a $74,9 \%$ \\
\hline $\begin{array}{l}\text { 5. Taxa de recuperação } \\
\text { de materiais recicláveis * }\end{array}$ & $>$ de 11\%* & Até 5\% & $5,1 \%$ a 10\% \\
\hline 6. Taxa de rejeito ** & Até 7\% & Acima de 21\% & $5,1 \%$ a $20 \%$ \\
\hline
\end{tabular}

Indicadores de sustentabilidade de organizações de catadores

\begin{tabular}{|c|c|c|c|}
\hline & \multicolumn{3}{|c|}{ Tendências à sustentabilidade } \\
\hline & + & - & $+/-$ \\
\hline $\begin{array}{l}\text { 1. Regularização da } \\
\text { organização }\end{array}$ & Regularizada & Não regularizada & --- \\
\hline $\begin{array}{l}\text { 2. Instrumento legal de } \\
\text { parceria }\end{array}$ & $\begin{array}{l}\text { Cooperativa c/ } \\
\text { convênio ou } \\
\text { OSCIP c/ } \\
\text { contrato }\end{array}$ & Não possui & $\begin{array}{l}\text { Associação com } \\
\text { convênio }\end{array}$ \\
\hline 3. Rotatividade anual & $\begin{array}{l}\text { Até } 25 \% \text { dos } \\
\text { membros }\end{array}$ & Mais de $50 \%$ & Entre 25 e $50 \%$ \\
\hline $\begin{array}{l}\text { 4. Capacitação dos } \\
\text { membros }\end{array}$ & Incubada & $\begin{array}{l}\text { Não incubada/não } \\
\text { capacitada }\end{array}$ & Capacitada \\
\hline
\end{tabular}




\begin{tabular}{|c|c|c|c|}
\hline \multicolumn{4}{|c|}{ Continuação: Indicadores de sustentabilidade de organizações de catadores } \\
\hline & \multicolumn{3}{|c|}{ Tendências à sustentabilidade } \\
\hline & + & - & $+/-$ \\
\hline $\begin{array}{l}\text { 5. Renda mensal por } \\
\text { membro }\end{array}$ & $\begin{array}{l}\text { Acima de dois } \\
\text { salários } \\
\text { mínimos }\end{array}$ & Um salário mínimo & Entre um e dois \\
\hline $\begin{array}{l}\text { 6. Participação dos } \\
\text { membros }\end{array}$ & $75 \%$ a $100 \%$ & Até $49,9 \%$ & $50 \%-74,9 \%$ \\
\hline 7. Condição da instalação & Própria & Cedida & Alugada \\
\hline 8. Equipamentos/veículos & Próprios & Cedidos & Próprios/cedidos* \\
\hline $\begin{array}{l}\text { 9. Horas trabalhadas } \\
\text { dia/membro }\end{array}$ & Mais de 6 & Até 4 & Entre 4 e 6 \\
\hline $\begin{array}{l}\text { 10. Benefícios aos } \\
\text { membros }\end{array}$ & 3 ou mais & Nenhum & Um ou dois \\
\hline 11. EPIs & Usam EPIs & Não possuem & Não usam \\
\hline 12. № de parcerias & Duas ou mais & Uma & Nenhum \\
\hline
\end{tabular}

* $\operatorname{TRMR}(\%)=$ Quantidade da coleta seletiva - quantidade de rejeito da triagem $\times 100$ Quantidade coletada seletivamente + quantidade da coleta regular

** TR $(\%)=\underline{\text { Quantidade da coleta seletiva }- \text { quantidade de materiais comercializados }} \times 100$

Quantidade da coleta seletiva

Extraído de: RIBEIRO et al., 2009.

A pesquisa COSELIX propôs duas matrizes de sustentabilidade, uma para a coleta seletiva e outra para as organizações de catadores, a partir das quais os indicadores e índices foram construídos e os resultados rankeados (Quadros 5 e 6). As matrizes possibilitam aos municípios e às organizações de catadores avaliarem seu grau de sustentabilidade e de estabelecer comparações tanto entre o desempenho dos municípios quanto aos das organizações dos catadores.

Segundo RIBEIRO et al., (2009), o índice e o grau de sustentabilidade estabelecidos possibilitaram uma avaliação comparativa e hierarquização da coleta seletiva entre os programas municipais entre si e da mesma forma, para as organizações de catadores. 
Quadro 5 - Matriz de sustentabilidade de coleta seletiva, COSELIX

\begin{tabular}{|c|c|c|c|c|c|c|c|c|}
\hline \multicolumn{8}{|c|}{ Coleta seletiva municipal } \\
\hline \multirow{3}{*}{ Municípios } & \multicolumn{7}{|c|}{ Indicadores de sustentabilidade* } & \multicolumn{2}{c|}{ Sustentabilidade } \\
\cline { 2 - 9 } & 1 & 2 & 3 & 4 & 5 & 6 & Índice & Grau** $^{* *}$ \\
\hline 1 & + & + & - & - & - & - & 2,0 & Médio \\
\hline 2 & - & + & - & + & - & $+/-$ & 2,5 & Médio \\
\hline 3 & $+/-$ & $+/-$ & $+/--$ & - & - & - & 1,5 & Baixo \\
\hline 4 & - & $+/-$ & $+/-$ & - & - & $+/-$ & 2,0 & Médio \\
\hline 5 & $+/-$ & $+/-$ & + & $+/-$ & - & $+/-$ & 3,0 & Médio \\
\hline 11 & & & & & & & & \\
\hline
\end{tabular}

*Notas e Pontuação: $-=0$ ponto, $+=1$ ponto, $+/-=0,5$ pontos *Grau: Alto- 4 a 6 pontos Médio -2 a 3,9 pontos Baixo- 0 a 1,9 pontos Adaptado pela autora. Fonte: RIBEIRO et al., 2009, pg. 93.

Quadro 6 - Matriz de sustentabilidade de organizações de catadores, COSELIX

\begin{tabular}{|c|c|c|c|c|c|c|c|c|c|c|c|c|c|c|}
\hline \multicolumn{15}{|c|}{ Organizações de Catadores } \\
\hline \multirow[t]{2}{*}{ Org. } & \multicolumn{12}{|c|}{ Indicadores de sustentabilidade } & \multicolumn{2}{|c|}{ Sustentabilidade } \\
\hline & 1 & 2 & 3 & 4 & 5 & 6 & 7 & 8 & 9 & 10 & 11 & 12 & İndice & Grau $^{* *}$ \\
\hline 1 & + & + & + & + & $+/-$ & + & - & +- & + & $+/-$ & - & + & 8,5 & Alto \\
\hline 2 & + & - & + & + & + & + & - & - & + & - & - & $+/-$ & 6,5 & Médio A \\
\hline 3 & + & + & - & + & $+/-$ & $+/-$ & - & $+/-$ & $+/-$ & - & + & - & 6,0 & Médio A \\
\hline 4 & - & - - & + & - & - & + & - & - & + & $+/-$ & + & - & 4,5 & Médio B \\
\hline 5 & - & - - & - & $+/-$ & - & + & - & - & + & - & + & $+/-$ & 5,0 & Médio B \\
\hline 32 & & & & & & & & & & & & & & \\
\hline
\end{tabular}

*A Alto $=8$ a 12 pontos Médio Alto $=6$ a 7,9 pontos Médio Baixo $=4$ a 5,9 pontos Baixo $=-0$ a 1,9 pontos.

Adaptado pela autora. Fonte: RIBEIRO et al., 2009, pg. 93. 
Resultou desta pesquisa que nenhum dos 11 municípios estudados atingiu alto grau de sustentabilidade da coleta seletiva, oito municípios atingiram grau médio de sustentabilidade, e três, baixo grau de sustentabilidade. Isto mostrou os pontos fortes e as debilidades que deslocam os respectivos índices e alteram os graus de sustentabilidade. Quanto à sustentabilidade das organizações de catadores, apenas duas atingiram alto grau de sustentabilidade. A maioria das organizações atingiu grau médio (28 organizações), o que representa $87,5 \%$; e duas delas se enquadraram em baixo grau de sustentabilidade.

Em termos do resultado dos indicadores de coleta seletiva nessa pesquisa, os que afetaram negativamente o índice de sustentabilidade dos programas foram: inexistência de taxa específica, índice de recuperação de materiais recicláveis e cobertura da coleta. Os indicadores que afetaram positivamente os programas foram: existência de marco legal e parcerias do programa. Com relação aos indicadores que afetaram negativamente o índice de sustentabilidade das organizações de catadores foram: inexistência de convênios firmados com as prefeituras; falta de área própria e de equipamentos/veículos próprios e baixa capacidade das organizações de proporcionarem benefícios aos seus membros. Os indicadores que afetaram positivamente a pontuação foram: situação de regularização das organizações, existência de cursos de capacitação e o fato de seus membros trabalharem mais de 6 horas.

VIEIRA e PINHEL (2009) realizaram uma análise evolutiva da coleta seletiva no município de Santana do Parnaíba (SP) a partir da aplicação dos indicadores da pesquisa COSELIX, durante três anos. Concluíram que o instrumento é adequado e permite planejar e monitorar a coleta seletiva na perspectiva de uma ampliação gradual do grau de sustentabilidade. 


\section{OBJETIVOS}

\subsection{OBJETIVO GERAL}

Identificar, construir e validar, de forma participativa, indicadores e índices de sustentabilidade para a gestão da coleta seletiva e de organizações sociais de catadores de materiais recicláveis, com o objetivo de fortalecer sua interface com a inclusão social de catadores e a saúde pública.

\subsection{OBJETIVOS ESPECÍFICOS}

a) Sistematizar os principais fatores que contribuem para a ampliação da coleta seletiva com organizações de catadores no Brasil.

b) Analisar a evolução da coleta seletiva, entre os anos de 2004 e 2010, na Região Metropolitana de São Paulo.

c) Elaborar instrumento de avaliação da gestão sustentável da coleta seletiva, para municípios e para as organizações de catadores, a partir de indicadores e índices de referência construídos de forma participativa.

d) Divulgar e ampliar o conhecimento dos indicadores e índices com atores diversos, para validação da metodologia de construção e dos indicadores e índices. 


\section{MÉTODOS E TÉCNICAS}

O método de avaliação e validação das definições e dos indicadores de sustentabilidade da pesquisa foi orientado no sentido de se obter definições e indicadores abrangentes e representativos da gestão da coleta seletiva e de gestão das organizações de catadores voltados à coleta seletiva, tendo como base as diferentes visões existentes, utilizando-se para tanto metodologias participativas.

Elaborou-se, um quadro sistematizado de indicadores de referência tanto para os municípios como para as organizações de catadores, aplicável à gestão sustentável da coleta seletiva no Brasil.

Esta pesquisa foi aprovada pelo Comitê de Ética em Pesquisa da Faculdade de Saúde Pública (protocolo 1789, of. COEP/48/2008). O Termo de Consentimento Livre e Esclarecido lido e assinado por todos os participantes da pesquisa encontra-se no APÊNDICE A.

Com vistas a atingir os objetivos estabelecidos de identificar, construir e validar definições e indicadores de sustentabilidade para a coleta seletiva e para organizações de catadores foram desenvolvidas seis estratégias e três etapas da pesquisa de campo, detalhadas a seguir.

\subsection{ESTRATÉGIAS DA PESQUISA}

Para atingir os objetivos propostos na pesquisa adotaram-se seis estratégias: 
a) Aprofundamento conceitual e revisão da literatura sobre os principais temas tratados, em suas várias interfaces: saúde, sustentabilidade, gestão de resíduos sólidos, coleta seletiva, organizações de catadores, e construção e validação de indicadores de sustentabilidade.

b) Aplicação de duas rodadas de questionários, com especialistas nos temas: de indicadores, gestão municipal de resíduos sólidos, coleta seletiva, organizações de catadores, por meio da técnica Delphi, para avaliação de: indicadores de sustentabilidade, suas características, forma de cálculo e tendências à sustentabilidade.

c) Realização de quatro oficinas regionais presenciais, nas quais a pesquisadora exerceu a função de facilitadora, nas cidades de: São Paulo, Belo Horizonte, Rio de Janeiro e Recife, no decorrer dos anos de 2007 e 2008. O público participante incluiu um amplo espectro de atores envolvidos com a coleta seletiva: acadêmicos, gestores, catadores, técnicos de ONGs, técnicos da iniciativa privada e consultores.

d) Realização de três oficinas presenciais com públicos específicos, nas quais a pesquisadora exerceu a função de facilitadora, em 2009 e 2010, em Belo Horizonte. A primeira oficina foi realizada com representantes de organizações de catadores de vários estados brasileiros; a segunda, com técnicos da Superintendência de Limpeza Urbana e da Prefeitura de Belo Horizonte (SLU); da terceira participaram os técnicos do Instituto Nenuca de Sustentabilidade (INSEA), organização não governamental que atua na capacitação de organizações de catadores no estado de Minas Gerais. As oficinas específicas com técnicos da SLU e do INSEA não haviam sido planejadas previamente. No entanto, os seguintes fatores definiram sua realização: 1) o interesse manifestado pelos dois grupos participantes, quando da realização da oficina com as organizações de catadores; 2) a avaliação de que seria de grande relevância ampliar o processo de validação dos indicadores, ouvindo 
grupos específicos de técnicos municipais e de uma organização não governamental; 3) a relevância da atuação dos dois grupos na cidade de Belo Horizonte, considerada referência e precursora na implantação da coleta seletiva com inclusão socioprodutiva de catadores no país; 4) disposição de ambos os grupos para aplicar futuramente os indicadores de sustentabilidade por eles validados e disponibilizar os resultados para a pesquisadora, o que não ocorreu até o presente momento e, 5) confirmação da posição de alguns autores que consideram ser possível a aplicação da técnica Delphi conjugada a outros procedimentos, em diálogo com o mundo real (PILL, 1971).

e) Levantamento de dados primários sobre a evolução da coleta seletiva da Região Metropolitana de São Paulo, em especial, com integração socioprodutiva de organizações de catadores de materiais recicláveis, em 2010. O objetivo desta pesquisa específica no âmbito da tese foi analisar de forma comparativa, a situação da coleta seletiva na Região Metropolitana de São Paulo, entre os anos de 2004 e 2010, tendo como foco principal, a coleta seletiva municipal operada conjuntamente com organizações de catadores. A existência de pesquisa anterior na RMSP e dados sistematizados do ano de 2004, na pesquisa COSELIX, 2005 (RIBEIRO et al., 2009) possibilitam atualizar o cenário da coleta seletiva na RMSP e verificar a sua evolução além de oferecer subsídios às políticas públicas de todas as esferas de governo para a melhoria de sua eficiência, ampliação, fortalecimento, inclusão socioprodutiva dos catadores de materiais recicláveis e o seu monitoramento.

f) Realização de visitas técnicas a várias cidades brasileiras e a organizações de catadores consideradas referência na prática da coleta seletiva e uma visita técnica internacional. O objetivo foi ampliar o conhecimento sobre iniciativas municipais de coleta seletiva e das organizações de catadores, em outras regiões do país, em municípios de 
diferentes portes e em âmbito internacional. Nas cidades de: Londrina (Paraná), Resende, Quati, Porto Real e Itatiaia (Rio de Janeiro), em Angatuba, Presidente Prudente, Santana do Parnaíba, Barueri, Itapevi, Embu, (São Paulo), e em Abreu e Lima na Região metropolitana de Recife.

Também foram visitadas duas organizações de catadores, consideradas como referência no país e que atuam sem apoio das prefeituras: a Cooperativa dos Agentes Ecológicos de Canabrava (CAEC), em Salvador (Bahia) e a Cooperativa Pró-Recife, em Recife (Pernambuco). Na cidade de Londrina foram visitadas sete cooperativas.

$\mathrm{Na}$ cidade de Bogotá (Colômbia), o conhecimento sobre o sistema de coleta seletiva da cidade e sua relação com catadores ${ }^{20}$, possibilitou uma visão ampliada sobre a coleta seletiva com inclusão social na América Latina. Duas centrais de triagem operadas por grupos de catadores foram visitadas:

- Galpão Bodega- operado por três grupos de catadores e criada a partir de uma articulação da Associação de Recicladores de Bogotá (ARB) com um grupo de empresas: Carrefour, Chapinero, Natura, Tetrapack, dentre outras;

- Centro de Reciclagem Alqueria no qual grupos de catadores operam a central de triagem que recebe os recicláveis coletados pela prefeitura de Bogotá.

\footnotetext{
${ }^{20}$ Entrevista com o Coordenador Gremial Silvio Ruiz, da ARB.
} 


\subsection{INDICADORES DE SUSTENTABILIDADE: CONSTRUÇÃO E VALIDAÇÃO}

A pesquisa de campo para a identificação, construção e validação dos indicadores de sustentabilidade para a coleta seletiva municipal e para as organizações de catadores foi realizada em três etapas (Figura 2).

Figura 2 - Etapas da Pesquisa de Campo

\section{1ㄹ ETAPA}

$1^{\text {a }}$ rodada da técnica Delphi com especialistas

4 Oficinas regionais

\section{$2^{2}$ ETAPA}

$2^{\text {a }}$ rodada da técnica Delphi com especialistas

\section{Oficinas específicas}

\section{TAPA}

Construção de duas matrizes e dois índices de sustentabilidade
Pesquisa sobre a coleta seletiva na região metropolitana de São Paulo 


\subsection{1 $1^{\text {a }}$ Etapa: $1^{\underline{a}}$ rodada Delphi e oficinas regionais}

O objetivo dessa etapa foi ampliar a apresentação e avaliação: das definições de sustentabilidade da coleta seletiva municipal e de organizações de catadores, assim como dos indicadores e respectivas tendências à sustentabilidade propostos na Pesquisa COSELIX com os diversos atores envolvidos - especialistas identificados. Além disso, realizaram-se oficinas regionais com um público mais amplo de profissionais e pessoas que atuam e se interessam pelo tema para ouvir as opiniões desses atores sobre os indicadores e a metodologia de construção dos mesmos.

Nessa etapa, dois conjuntos de indicadores foram avaliados, um para a coleta seletiva municipal e outro para as organizações de catadores. A opção pelo uso de indicadores concebidos na pesquisa COSELIX, baseou-se no fato de se tratarem de indicadores que pretendem medir programas de gestão e direcionar políticas. Ambas as pesquisas são concordantes e complementares, baseando-se na mesma premissa: a utilização de indicadores para mensurar e avaliar a gestão da coleta seletiva pela administração municipal, como também a gestão das organizações de catadores.

A opção da Pesquisa COSELIX em manter dois grupos de indicadores um para a coleta seletiva e um para organizações de catadores foi mantida, uma vez que a avaliação da sustentabilidade da coleta seletiva enquanto prestação de serviço municipal difere da avaliação da sustentabilidade de uma organização social prestadora do serviço. Desta forma também é possível que prefeituras que não desenvolvem coleta seletiva com organizações de catadores e organizações de catadores trabalham de forma independente da prefeitura também apliquem os indicadores.

A técnica Delphi foi selecionada para o processo de validação dos indicadores, pois consiste numa técnica reconhecida para se obter a avaliação de especialistas em pequena e larga escala e para abordar problemas complexos ou incertos ou quantificar variáveis que ainda são intangíveis, 
imprecisas (PILL, 1971; LANDETA, 1999; LINSTONE Y TUROFF, 2002), como ocorre no caso de medir a sustentabilidade da coleta seletiva e das organizações de catadores. Também foi escolhida por possibilitar a participação no processo, de especialistas que residem em várias regiões do país, e assim fortalecer a credibilidade do estudo para sua futura utilização.

Em 1950, a técnica Delphi foi utilizada, com finalidades organizacionais, pela RAND Corporation de Santa Monica, Califórnia, EUA (PILL, 1971). A técnica é descrita por KAYNAK e MACAULEY (1984, p.90) como "o único método de produzir e refinar o julgamento de um grupo de especialistas baseado no fato de que é melhor o julgamento de um grupo do que de um único especialista, quando o conhecimento não é exato". Também passou, mais recentemente a ser empregada para a elaboração de cenários e tendências futuras e formulação de políticas (LINSTONE e TUROFF, 2002; SOUZA e LAMOUNIER, 2006).

De acordo com vários autores (LANDETA, 1999; WRIGHT e GIOVINAZZO, 2000; LINSTONE Y TUROFF, 2002) a técnica Delphi implica na seleção de um grupo de especialistas, pessoas que entendem do assunto a ser tratado e possam contribuir com subsídios e conhecimentos baseados em sua experiência profissional específica. Estes respondem a uma rodada ou mais de perguntas agrupadas em questionários. Os resultados de cada rodada são analisados e comunicados (devolvidos) aos membros do grupo que, após tomarem conhecimento, são submetidos à nova rodada de questões, sucessivas e complementares. As interações devem se suceder até que um consenso ou quase consenso seja obtido. Em geral, recomendam-se três rodadas de aplicação, porém este número depende dos objetivos e resultados obtidos. Para caracterizar o método Delphi, são necessárias no mínimo duas rodadas, sendo raros os exemplos de estudos com mais de três rodadas de aplicação de questionários (WRIGHT e GIOVINAZZO, 2000). No Quadro 7 apresentam-se algumas vantagens e desvantagens do uso da técnica Delphi. 
Quadro 7 - Vantagens e desvantagens da aplicação da técnica Delphi

\begin{tabular}{|ll|}
\hline \multicolumn{1}{|c|}{ Vantagens } & \multicolumn{1}{c|}{ Desvantagens } \\
\hline $\begin{array}{l}\text { Qualifica o nível de discussão e amplia a } \\
\text { possibilidade de aceitação e uso dos } \\
\text { indicadores validados conjuntamente. }\end{array}$ & $\begin{array}{l}\text { O fato dos critérios de seleção da } \\
\text { amostra de respondentes ser definido } \\
\text { pelo pesquisador. }\end{array}$ \\
\hline $\begin{array}{l}\text { Questionários individuais facilitam a reflexão } \\
\text { e o registro em relação ao processo } \\
\text { desenvolvido em grupo. }\end{array}$ & $\begin{array}{l}\text { Excessiva dependência dos } \\
\text { resultados e possibilidade de } \\
\text { introdução de viés. }\end{array}$ \\
\hline $\begin{array}{l}\text { O anonimato elimina a influência de fatores } \\
\text { como "status" acadêmico ou profissional ou a } \\
\text { oratória na defesa de argumentos. }\end{array}$ & $\begin{array}{l}\text { Possibilidade de se forçar o consenso } \\
\text { indevidamente }\end{array}$ \\
\hline $\begin{array}{l}\text { Reduz fatores restritivos de dinâmicas de } \\
\text { grupo tais como: supressão de posições } \\
\text { minoritárias, omissão de participantes, } \\
\text { manipulação política, dentre outras. }\end{array}$ & $\begin{array}{l}\text { Dificuldade de se redigir um } \\
\text { questionário sem ambigüidades e } \\
\text { sem viés sobre tendências futuras. }\end{array}$ \\
\hline $\begin{array}{l}\text { Reduz custos com pessoal, deslocamento, e } \\
\text { independe de agendas e pode envolver } \\
\text { especialistas no país e no exterior. }\end{array}$ & $\begin{array}{l}\text { Longa duração do processo } \\
\text { especialmente no caso de envio dos } \\
\text { questionários por correio. }\end{array}$ \\
\hline $\begin{array}{l}\text { O engajamento no processo de um grande } \\
\text { número de participantes com atuação em } \\
\text { diferentes regiões do país induz à criatividade } \\
\text { e confere credibilidade ao estudo }\end{array}$ & $\begin{array}{l}\text { A pesquisa com especialistas de uma } \\
\text { cidade ou região dificulta captar nas } \\
\text { respostas, as diferentes realidades } \\
\text { locais e regionais. }\end{array}$ \\
\hline $\begin{array}{l}\text { Possibilidade de realizar várias rodadas de } \\
\text { questionários. }\end{array}$ & $\begin{array}{l}\text { Aumento da dificuldade de obtenção } \\
\text { de respostas a cada rodada. }\end{array}$ \\
\hline $\begin{array}{l}\text { Processo de validação não necessariamente } \\
\text { por meios estatísticos }\end{array}$ & $\begin{array}{l}\text { Dificuldade de aceitação científica de } \\
\text { resultados não estatísticos. }\end{array}$ \\
\hline
\end{tabular}

Organizado pela autora com base em: LANDETA, 1999; WRIGHT E GIOVINAZZO, 2000; LINSTONE Y TUROFF, 2002. 
Segundo SOUZA e LAMOUNIER (2006) o método não requer consenso, posto que a opinião majoritária é representada pela mediana. Os autores consideram o método útil para responder a questões específicas, uma vez que cenários mais complexos e que envolvem múltiplos fatores requerem outros métodos que podem utilizar as estimativas Delphi como insumos.

Dada a especificidade da presente pesquisa, optou-se pela análise dos resultados da aplicação da técnica Delphi a partir de: 1) Percentual de especialistas que atribuíram nota aos indicadores, estratificada da seguinte forma: muito alta (nota 10), alta (notas 8 e 9) média (notas 7 e 6 ) e baixa (notas 0 a 5); e 2) Percentual de especialistas que se posicionaram, sobre as fórmulas de cálculo dos indicadores e suas respectivas tendências à sustentabilidade propostas, nas seguintes opções: concordam - C, concordam parcialmente - CP e discordam - D.

Após as rodadas iniciais de aplicação da técnica Delphi, devido aos altos níveis de consenso obtidos na $1^{\text {a }}$ e na $2^{\underline{a}}$ rodadas e ao retorno decrescente do número de questionários respondidos, optou-se pela realização de duas rodadas apenas.

$\mathrm{Na} 1^{\text {a }}$ rodada de aplicação dos questionários foram desenvolvidas as seguintes atividades:

a) Identificação de especialistas com atuação diversificada no território nacional. A seleção dos mesmos partiu do conhecimento e experiência acumulados pela autora nos temas da pesquisa, como também de seus orientadores, e da solicitação de indicações a cada um dos especialistas contatados ou recomendados.

b) Elaboração e envio de questionário (APENDICE B), por meio eletrônico, contendo informações sobre a pesquisa, instruções de preenchimento, e o Termo de Consentimento Livre e Esclarecido. O envio e recebimento 
dos questionários ocorreram entre os meses de julho e agosto de 2008. O prazo de retorno dos questionários foi ampliado por duas vezes, em atendimento às solicitações dos participantes. No questionário da $1^{\text {a }}$ rodada partiu-se das definições de sustentabilidade e de um conjunto de indicadores de sustentabilidade obtidos como resultado da pesquisa COSELIX (RIBEIRO et al., 2009), na qual a pesquisadora participou como bolsista. Foram submetidas: a) duas definições de sustentabilidade, uma para coleta seletiva municipal e outra para organizações de catadores de materiais recicláveis; e b) um total de 18 indicadores de sustentabilidade, sendo 6 indicadores de sustentabilidade da coleta seletiva, e 12 indicadores de sustentabilidade para organizações de catadores e suas respectivas tendências à sustentabilidade, graduadas em: alta (+), média (+/-) ou baixa (-).

Antes do envio dos questionários foi realizado pré-teste, no decorrer do mês de maio de 2008, e em seguida, as adequações e ajustes no questionário.

Do total de 112 especialistas contatados, 88 acusaram o recebimento da correspondência eletrônica e 59 (67\%) especialistas participaram da pesquisa e assinaram o Termo de Consentimento Livre e Esclarecido.

c) Análise estatística descritiva das respostas obtidas nos questionários aplicados nas duas rodadas de aplicação do Delphi. Utilizou-se o tratamento estatístico com emprego do software Epi Info ${ }^{21}$.

d) Análise qualitativa das respostas dos especialistas e elaboração de novos indicadores e índices propostos.

${ }^{21}$ Software de domínio público criado pelo CDC (Centers for Disease Control and Prevention) para o gerenciamento e a análise de bancos de informações, geralmente utilizado por profissionais que atuam na área de saúde pública. 
Os critérios de seleção das características dos indicadores submetidas à avaliação dos especialistas também foram definidos nesta etapa. Essa avaliação objetivou verificar o que JANUZZI (2006) denomina de "validade de constructo" do indicador, refletir de fato o conceito abstrato a que o indicador se propõe a substituir ou operacionalizar, atendendo a vários critérios. Com base em MILANEZ (2002), MIRANDA (2003), BRINGHENTI (2004) e POLAZ (2008) que trabalharam com critérios de validação de indicadores de sustentabilidade na área de resíduos sólidos e saneamento, no Brasil, foram selecionadas cinco características dos indicadores de sustentabilidade para avaliação dos especialistas, na $2^{a}$ rodada da aplicação da técnica Delphi:

a) Representatividade - Relevância do indicador para o que se pretende medir;

b) Comparabilidade- Amplitude geográfica adequada, padronização, e sensibilidade a mudanças no tempo. O indicador deve ser comparável tanto no espaço (diferentes cidades, por exemplo) como no tempo (anos diferentes);

c) Coleta de dados- Acessibilidade dos dados, confiabilidade da fonte. Os dados devem ser de fácil acesso e sem custos excessivos;

d) Clareza e síntese- Clareza na comunicação e capacidade de síntese. $O$ indicador sintetiza e transmite a informação de maneira simples e compreensível;

e) Previsão e metas- Pró-atividade, facilidade para definição de metas, preditividade. $\mathrm{O}$ indicador fornece previsões dos problemas e estimula a definição de metas de melhorias.

Concomitante com a 1 ${ }^{\underline{a}}$ rodada da pesquisa Delphi, nos anos de 2007 e 2008, foram realizadas quatro oficinas regionais, nas quais a pesquisadora atuou como facilitadora, nas cidades de São Paulo, Belo Horizonte, Rio de 
Janeiro e Recife. Nestas oficinas foram apresentados e discutidos os indicadores da 1a rodada do Delphi. O objetivo foi apresentar a metodologia de construção dos indicadores e dos índices avaliados por especialistas, na $1^{\text {a }}$ rodada da técnica Delphi e verificar a sua aceitação.

Essa etapa possibilitou também identificar quais os indicadores considerados relevantes para serem considerados e avaliados na $2^{\mathrm{a}}$ rodada.

A primeira oficina foi realizada na cidade de São Paulo, em 2007, em parceria com o Fórum Lixo e Cidadania do Estado de São Paulo (CONVITE APÊNDICE C). A segunda oficina ocorreu em Belo Horizonte, em 2007, e em parceria com a Fundação Centro Tecnológico de Minas Gerais - CETEC (CONVITE APÊNDICE D). A terceira, no Rio de Janeiro, em 2008, em parceria com o Fórum Lixo e Cidadania do Estado do Rio de Janeiro, a Secretaria de Estado do Ambiente, SEBRAE-RJ, a Universidade Federal do Rio de JaneiroUFRJ e a Associação Brasileira da Indústria de Higiene Pessoal, Perfumaria e Cosméticos- ABIPHEC no âmbito do evento "Os Rumos da coleta seletiva: Boas Práticas e Indicadores de Sustentabilidade" (CONVITE APÊNDICE E). A quarta oficina, em Recife, em 2008, foi realizada em parceria com o Fórum Lixo e Cidadania do Estado de Pernambuco- FLIC (CONVITE APÊNDICE F).

\subsection{2 $2^{\mathrm{a}}$ Etapa: $2^{\mathrm{a}}$ rodada Delphi e oficinas específicas}

Nessa etapa foi aplicada a $2^{a}$ rodada de questionários com especialistas. Também foram realizadas três oficinas específicas em Belo Horizonte. Os objetivos desta etapa foram os seguintes: 
a) Validar as definições de sustentabilidade da coleta seletiva e das organizações de catadores pelos especialistas e nas oficinas específicas;

b) Avaliar os indicadores e obter os pesos a eles atribuídos, pelos especialistas, para a construção da matriz de sustentabilidade na $3^{\text {a }}$ Etapa;

c) Avaliar as características dos indicadores;

d) Avaliar os indicadores nas oficinas específicas, mediante três opções: Aprovação- A, Aprovação com Ressalvas- AR e Reprovação-R.

$\mathrm{Na} 2^{\mathrm{a}}$ rodada de aplicação da técnica Delphi, foi elaborado e enviado um novo questionário (APÊNDICE G), também por meio eletrônico para os 59 especialistas que responderam à rodada anterior. Anexo ao questionário foi enviado um relatório com os resultados da rodada anterior visando subsidiar o entendimento do processo e as avaliações nesta rodada.

A aplicação do pré-teste do questionário da segunda rodada e sua adequação ocorreram no decorrer dos meses de abril e maio de 2009. O envio e recebimento dos questionários ocorreram entre os meses de setembro e outubro de 2009. $\mathrm{Na} 2^{\underline{a}}$ rodada devido às solicitações dos especialistas, o prazo de retorno dos questionários foi ampliado duas vezes.

Concomitantemente à aplicação da $2^{a}$ rodada da técnica Delphi ocorreram três oficinas específicas de avaliação dos indicadores da segunda rodada, nas quais a pesquisadora atuou como facilitadora. A primeira oficina reuniu 27 representantes de organizações de catadores, de vários estados brasileiros, e ocorreu paralela ao $8^{\circ}$ Festival Lixo e Cidadania de Belo Horizonte, em 2009 (Convite APÊNDICE H). A proposta inicial da pesquisa foi desenvolver uma oficina de organizações de catadores em parceria com o Movimento Nacional dos Catadores e incluir nesta oficina representações de 
várias regiões do país. No entanto, apesar das várias tentativas junto ao MNCR não foi possível concretizar esta proposta. Da segunda oficina participaram 28 técnicos da Superintendência de Serviço de Limpeza Urbana (SLU) e da Prefeitura de Belo Horizonte. Na terceira, participaram 12 técnicos do Instituto Nenuca de Desenvolvimento Sustentável (INSEA), organização não governamental com ampla experiência na assessoria às organizações de catadores do Estado de Minas Gerais.

\subsubsection{3ํㅡㄹ Etapa: Elaboração de matrizes e índices}

A partir da sistematização dos resultados da aplicação da técnica Delphi a especialistas e das oficinas regionais e específicas realizadas, foi possível construir matrizes a partir das quais é possível calcular os índices de sustentabilidade tanto para coleta seletiva quanto para organizações de catadores. As respostas dos especialistas definiram a escolha do conjunto de indicadores que compuseram as matrizes e suas respectivas ponderações, a partir das médias das notas atribuídas aos indicadores. Utilizaram-se as médias aritméticas das notas atribuídas aos indicadores, pelos especialistas, para atribuir os pesos dos indicadores de forma a contemplar todos os participantes do Delphi, inclusive os que atribuíram notas muito baixas a alguns indicadores.

As oficinas regionais contribuíram para a proposição dos indicadores da $2^{2}$ rodada e as oficinas específicas, com a avaliação dos indicadores propostos na $2^{\text {a }}$ rodada, que embasaram a construção das matrizes de sustentabilidade.

Nas matrizes, os valores finais de cada um dos indicadores resultaram da multiplicação do seu peso pelo valor que obtiveram no quesito tendência à sustentabilidade. Para tanto, foi atribuída ao quesito tendência à sustentabilidade a valoração, decodificada nas seguintes pontuações:

- Muito favorável ou alta - símbolo + (mais) e valor de 1 ponto; 
- Favorável ou média - símbolo +/- (mais ou menos) e o valor de 0,5 pontos;

- Desfavorável ou baixa - símbolo - (menos) e 0 ponto.

Com base nos indicadores que compõem as matrizes, foram elaborados os respectivos índices. O valor numérico do índice de sustentabilidade da coleta seletiva ou da organização de catadores resultou igual à somatória da multiplicação entre o valor e o peso atribuídos pelos especialistas, a cada um dos indicadores, dividido pela somatória dos pesos atribuídos. Esse número obtido representa o índice de sustentabilidade da coleta seletiva de um município, ou da organização de catadores. Os valores finais dos índices obtidos podem variar entre 0 e 1 ponto. $O$ valor final do índice obtido, que representa o índice de sustentabilidade da coleta seletiva de um município ou de uma organização de catadores variar entre 0 e 1 ponto, sendo $o$ valor máximo o mais próximo da sustentabilidade. fórmula:

Os valores numéricos dos índices de sustentabilidade são obtidos pela

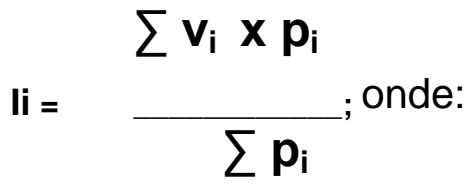

$\mathbf{l i}=$ Índice

$\Sigma=$ somatória

$\mathrm{V}_{\mathrm{i}}=$ valor da tendência à sustentabilidade do indicador

$\mathrm{p}_{\mathrm{i}}=$ peso atribuído ao indicador $\mathrm{i}$

A partir da análise dos resultados da pesquisa, constatou-se a importância de construir um instrumento que estabelecesse graus de 
sustentabilidade, aos quais os índices estariam referenciados. Daí surgiu a proposta de estabelecer uma gradação que permitisse a hierarquização dos municípios e das organizações de catadores. Nesta hierarquização, baseada em escala numérica, é facilitada a visualização e a compreensão, tanto por parte dos municípios quanto das organizações, de suas condições com relação à sustentabilidade, portanto foi denominada Radar da Sustentabilidade.

\subsubsection{Instrumento de Comunicação}

O instrumento que denominamos de Radar da Sustentabilidade foi construído com o objetivo de facilitar a compreensão dos usuários e interessados: municípios, órgãos públicos, tomadores de decisão, organizações de catadores, mídia em geral e pesquisadores, quanto ao desempenho atual da gestão e suas possibilidades de melhoria. Também pode ser utilizado pela sociedade para monitorar a evolução da coleta seletiva.

A pesquisa elaborou o radar e sua visualização numérica a partir do entendimento de que este é um dispositivo que permite detectar o objeto em questão, ou seja, a gestão sustentável, tanto da coleta seletiva para o município e o público em geral, quanto das organizações de catadores.

A construção inspirou-se em modelos existentes aplicados aos indicadores de desenvolvimento e sustentabilidade, tais como o Barômetro da Sustentabilidade e o Painel da Sustentabilidade - Dashboard of Sustainability (BELLEN, 2005, VEIGA, 2009). O Radar da Sustentabilidade possibilita a localização entre a fotografia do presente e as metas gradativas de futuro voltadas para a gestão sustentável.

O estabelecimento dos graus de sustentabilidade se deu com a definição de quatro intervalos de valores para o respectivo índice, que variaram entre $0 \mathrm{e}$ 1. 
- Índice de 0 a 0, 25 - muito desfavorável;

- Índice de 0,26 a 0,50 - desfavorável;

- Índice de 0,51 a 0,75 - favorável;

- Índice de 0,76 a 1,00 - muito favorável.

O índice indica que quanto mais próximo do valor 1 , maior o grau de sustentabilidade e quanto mais distante, menos sustentável.

\subsection{COLETA SELETIVA NA REGIÃO METROPOLITANA DE SÃO PAULO}

Em março de 2010, foi realizado um levantamento de dados sobre a coleta seletiva nos 39 municípios da Região Metropolitana de São Paulo RMSP. A finalidade deste levantamento foi verificar a evolução da coleta seletiva na região metropolitana e os impactos das políticas públicas de inclusão de catadores no período entre 2004 e 2010. Optou-se pela região metropolitana de São Paulo devido à existência de dados sistematizados dos anos de 2004 e 2005 (RIBEIRO et al., 2009).

Os dados referentes à coleta regular e disposição final dos resíduos sólidos domiciliares dos municípios foram atualizados por meio de dados secundários obtidos no Inventário Estadual de Resíduos Sólidos Domiciliares da CETESB. Os dados do município de São Paulo foram disponibilizados pela Assessoria de Comunicação da Prefeitura Municipal, em 2010.

No que se refere aos dados sobre coleta seletiva municipal e organizações de catadores, no período de 2004 a 2005, utilizou-se os dados da pesquisa COSELIX (GÜNTHER et al., 2006; RIBEIRO et al., 2009).

A atualização da situação da coleta seletiva na RMSP foi realizada por meio da coleta de dados primários. O instrumento utilizado foi o questionário 
inicial exploratório da pesquisa COSELIX, acrescido de uma questão sobre a renda média mensal auferida por membro das organizações.

A aplicação do questionário foi realizada por meio telefônico, ou eletrônico para aqueles que assim o solicitaram. Em alguns casos responderam ao questionário o representante do órgão municipal responsável pela coleta seletiva ou o gestor. Em alguns casos os gestores solicitaram o contato direto com as organizações de catadores.

Levantaram-se os seguintes dados:

\section{a) Coleta seletiva municipal:}

- Existência de coleta seletiva;

- Existência de coleta seletiva com organizações de catadores;

- Existência de projeto de implantação da coleta seletiva;

- Ano de inicio da coleta seletiva em parceria com catadores;

- Abrangência da coleta seletiva;

- Existência de contrato de remuneração dos catadores.

\section{b) Organizações de Catadores:}

- Número de organizações que atuam em parceria com as prefeituras;

- Estrutura legal das organizações - cooperativas ou associações;

- Número de membros das organizações;

- Quantidade média mensal de material comercializado;

- Renda Média mensal por membro da organização; 


\section{RESULTADOS E DISCUSSÃO}

Nesse capítulo serão apresentados os resultados e a discussão da pesquisa que envolveu levantamento documental e de campo, aplicação de instrumento de validação de indicadores, realização de atividades com diversos atores sociais e elaboração de instrumento de comunicação para os atores envolvidos e para a sociedade em geral.

O primeiro tópico apresenta uma atualização da evolução da coleta seletiva, em especial, operada pelas administrações municipais com organizações de catadores na Região Metropolitana de São Paulo, a partir de um estudo comparativo, entre os anos de 2004 e 2010. Esta atualização visa atingir um dos objetivos da pesquisa que é verificar os fatores que afetaram a coleta seletiva, a situação atual da gestão dos resíduos sólidos na RMSP, as mudanças ocorridas no período e permite avaliar os impactos das políticas públicas e do seu alcance na inclusão de catadores.

No segundo tópico são apresentados resultados da realização de duas rodadas de questionários da técnica Delphi, com especialistas, para a construção e validação dos indicadores de sustentabilidade da coleta seletiva municipal e das organizações de catadores.

O terceiro contém as contribuições dos participantes das oficinas regionais, realizadas no decorrer dos anos de 2007 e 2008, nas cidades de São Paulo, Belo Horizonte, Rio de Janeiro e Recife, durante a $1^{\text {a }}$ rodada da aplicação do Delphi. O objetivo das oficinas regionais foi verificar a aceitação da metodologia de construção dos indicadores e dos índices e colher subsídios para a $2^{a}$ rodada técnica Delphi.

No quarto tópico apresentam-se os resultados obtidos nas três oficinas de validação dos indicadores realizadas com: 1) representantes de 
organizações de catadores, 2) técnicos da SLU/BH, e da prefeitura de Belo Horizonte, e 3) técnicos do Instituto INSEA.

Duas matrizes de sustentabilidade são apresentadas no quinto tópico, uma referente à coleta seletiva e outra às organizações de catadores, ambas construídas a partir dos resultados obtidos no Delphi e nas demais fases da pesquisa. Nesse tópico também se encontra a proposta do Radar de Sustentabilidade da coleta seletiva, uma forma de comunicação dos índices obtidos a partir das matrizes, com o objetivo de facilitar o monitoramento e a evolução, em termos de sustentabilidade, pelas prefeituras e pelas organizações de catadores.

\subsection{COLETA SELETIVA NA REGIÃO METROPOLITANA DE SÃO PAULO}

As 26 Regiões Metropolitanas do país concentram 34\% da população brasileira e $84 \%$ da população urbana ${ }^{22}$. A Região Metropolitana de São Paulo - RMSP, o maior centro urbano do Brasil e da América do Sul, e a sexta maior área urbana do mundo, com cerca de 19.9 milhões de habitantes (IBGE, 2009) destaca-se como centro econômico é responsável por $57,3 \%$ do PIB estadual, $19,4 \%$ do nacional.

Os níveis de qualidade de vida variam muito entre os 39 municípios da RMSP, sendo que alguns apresentam indicadores comparáveis aos de países desenvolvidos, enquanto outros se comparam a países em desenvolvimento, e ainda persistem desigualdades econômico-sociais intra-regionais. Embora a gestão dos resíduos sólidos urbanos seja uma atribuição municipal, a inexistência de política de planejamento e gestão integrada para as Regiões

\footnotetext{
${ }^{22}$ Observatório de Saúde da Região Metropolitana de São Paulo, 2010. Disponível em: www.observasaude.sp.gov.br.
} 
Metropolitanas reflete-se na gestão dos resíduos sólidos, que se dá de forma fragmentada.

Estima-se que nos 39 municípios são geradas 16.233 toneladas por dia ou quase 6 milhões de toneladas por ano de resíduos sólidos domiciliares (CETESB, 2009). O município de São Paulo é responsável pela geração estimada de mais da metade $(62,5 \%)$ desses resíduos. Os resíduos urbanos gerados na RMSP representam quase 10\% dos resíduos sólidos urbanos (RSU) gerados no país (ABRELPE, 2008; CETESB, 2009).

A evolução da coleta seletiva na RMSP, entre os anos de 2005 e 2010, foi analisada a partir de dados secundários, de 2005 e primários, de 2010 . Os dados referentes aos anos de 2004 e 2005 foram obtidos na pesquisa COSELIX (RIBEIRO et al., 2009 págs 32 e 33). O levantamento de dados referentes ao ano de 2010 foi realizado no âmbito da pesquisa aqui apresentada, e os resultados encontram-se no APENDICE I.

a) Geração e destinação final de resíduos sólidos domiciliares

Para avaliar a eficiência da prestação do serviço de coleta seletiva pelos municípios é importante verificar a relação entre a quantidade coletada de forma seletiva e total de resíduos domiciliares, coletados e destinados aos aterros sanitários. São considerados resíduos domiciliares os de origem domiciliar produzidos nas residências, em pequenos estabelecimentos comerciais e em empreendimentos de pequeno porte destinados à prestação de serviços coletados pela coleta regular municipal (CETESB, 2009, p. 6).

Vários autores alertam sobre a dificuldade de se obter dados comparativos referentes à produção de resíduos sólidos entre diferentes países ou municípios, devido ao uso de diferentes nomenclaturas para as categorias de resíduos sólidos gerados no ambiente urbano (ACURIO et al., 1997; MILANEZ, 2002; LOPES, 2003; ABRELPE, 2009). Os resíduos sólidos urbanos 
são aqueles produzidos nas residências, nos pequenos geradores comerciais, nas atividades de limpeza pública, como é o caso da varrição de vias e logradouros públicos e cuja competência é da administração municipal. Também há variações de quantidades em municípios, devido a fatores tais como: tipo de atividade produtiva predominante, nível socioeconômico, sazonalidade de ocupação e existência de programas de coleta seletiva, dentre outros. Há ainda a questão da freqüência da medição, pois nem todos os municípios fazem pesagens diárias ou periódicas (CETESB, 2009).

As quantidades de RSD coletadas, em 2005 e $2009^{23}$ são apresentadas na Tabela 2.

Tabela 2 - Coleta de resíduos domiciliares, quantidades coletadas e variação percentual na RMSP, 2005 e 2009.

\begin{tabular}{|l|c|cc|c|}
\hline \multicolumn{4}{|c|}{ Municípios da RMSP } \\
\hline \multirow{2}{*}{} & \multicolumn{3}{c|}{ Coleta de RSD } \\
\cline { 2 - 5 } & $\begin{array}{c}2005 \\
\text { (t/dia) }\end{array}$ & $\begin{array}{c}2009 \\
\text { (t/dia) }\end{array}$ & $\begin{array}{c}\text { Variação } \\
(\%)\end{array}$ \\
\hline 39 municípios & 17.692 & 16.213 & $-8,4$ \\
\hline \multirow{2}{*}{38 municípios (exceto São Paulo) } & 4.692 & 5.213 & 11,1 \\
\hline \multirow{3}{*}{ São Paulo } & CETESB $^{*}$ & 7.000 & 11.000 & 57,0 \\
\cline { 2 - 4 } & PMSP** $^{*}$ & 10.342 & 11.618 & 12,3 \\
\hline
\end{tabular}

*Inventário Estadual de Resíduos Sólidos Domiciliares - CETESB, 2005, 2009 **Assessoria de Comunicação da PMSP, maio de 2010.

${ }^{23}$ A partir de dados estimados da Companhia de Tecnologia de Saneamento AmbientalCETESB, nos Inventários Estaduais de Resíduos Sólidos, de 2005 e 2009, e em dados fornecidos pela Prefeitura Municipal de São Paulo, em 2010. 
Embora a CETESB alerte para que as estimativas de geração não sejam utilizadas como fonte de informação de dados de geração ou coleta de resíduos (CETESB, 2009, pg.6), cabe destacar a dificuldade na obtenção de dados confiáveis e a discrepância entre os dados fornecidos pela prefeitura municipal de São Paulo e os da CETESB (Tabela 3).

Também é importante observar que segundo os dados da Prefeitura de São Paulo, o crescimento da quantidade de resíduos domiciliares, entre os anos de 2005 e 2009, não foi muito significativa, o que pode gerar dúvidas quanto à confiabilidade dos dados (Tabela 3 ).

Tabela 3 - Coleta de resíduos domiciliares do município de São Paulo, no período 2004 - 2009.

\begin{tabular}{|l|c|c|c|c|c|c|}
\hline \multicolumn{7}{|c|}{ Coleta de RSD (t/dia) } \\
\hline & 2004 & 2005 & 2006 & 2007 & 2008 & 2009 \\
\hline CETESB $^{*}$ & 13.000 & 7.000 & 7.000 & 12.700 & 10.600 & 11.000 \\
\hline $\begin{array}{l}\text { Prefeitura de São } \\
\text { Paulo** }\end{array}$ & 10.096 & 10.342 & 10.879 & 10.737 & 11.082 & 11.618 \\
\hline
\end{tabular}

*Inventários Estaduais de Resíduos Sólidos Domiciliares- CETESB - 2004, 2005, 2006, 2007, 2008, e 2009.

${ }^{* *}$ Assessoria de Comunicação da PMSP, maio de $2010^{24}$.

Essa variação nas quantidades identificadas da coleta de RSD pela Prefeitura Municipal de São Paulo altera significativamente o resultado da quantidade total de resíduos coletada na RMSP, e afeta a avaliação dos demais municípios no que se refere ao cálculo da evolução do percentual coletado

${ }^{24}$ Os dados foram informados em t/ano e transformados pela autora em t/dia. Para o cálculo foram considerados 26 dias de coleta. 
nesses (se considerados os dados da CETESB), ao longo dos anos, em relação ao total produzido na RMSP.

Em 2010, a disposição final de RSD coletados na RMSP é feita, na sua totalidade, em aterros sanitários.

Os Mapas 1 e 2 apresentam a localização e condições da disposição final dos RSD na RMSP, em 2005 e 2009 e mostram que a situação melhorou significativamente nesse período ${ }^{25}$. Também apresentam o fluxo e as distâncias percorridas pelos resíduos sólidos domiciliares na RMSP para uma disposição final adequada em aterros sanitários.

O número de municípios que realizam a disposição final em outros municípios aumentou de 23, em 2005 para 32, em 2009. Na RMSP, de estimadas 5.236,6 t/dia de RSD geradas nos 38 municípios (São Paulo dispõe em condições adequadas), 2.0658,6 t/dia (39,3\%) ainda estão sendo dispostos em condições controladas. Esse tipo de disposição, na qual os requisitos de engenharia necessários para a segurança não foram tomados, representa riscos ao ambiente e à saúde pública, uma vez que diante de chuvas excessivas estas áreas podem rapidamente se transformar em lixões.

Aumenta também a disposição final em aterros sanitários privados. Esses aterros, em sua maioria operam em condições adequadas. A tendência futura, nas regiões metropolitanas e cidades médias é a disposição final em aterros instalados em áreas cada vez mais distantes, devido às dificuldades de obtenção de áreas para instalação de aterros e à resistência das comunidades quanto à sua proximidade (GÜNTHER e GRIMBERG, 2006; BESEN, 2006). Estas distâncias representam aumento de emissões de $\mathrm{CO}_{2}$, desperdício de tempo, gastos com transporte, assim como desgaste das vias públicas.

\footnotetext{
${ }^{25}$ Em 2009, na RMSP, 8 municípios dispunham no aterro de Itaquaquecetuba em condições controladas e 2 em Santa Isabel, em condições controladas. Os demais dispunham em condições adequadas (aterros sanitários).
} 
MAPA 1 - Destinação e condição da disposição final de resíduos domiciliares na RMSP, 2005.

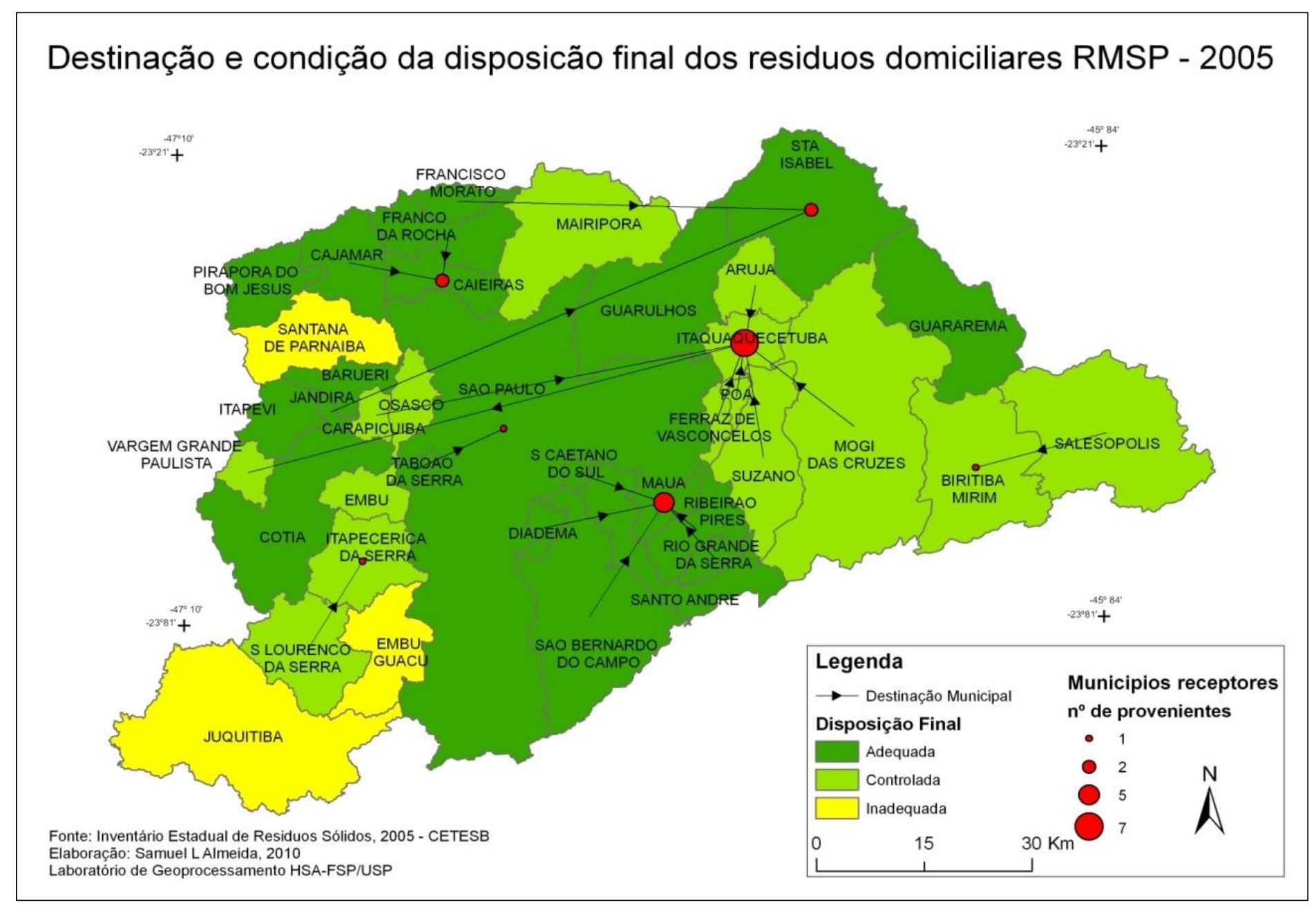


MAPA 2 - Destinação e condição da disposição final de resíduos domiciliares na RMSP, 2009.

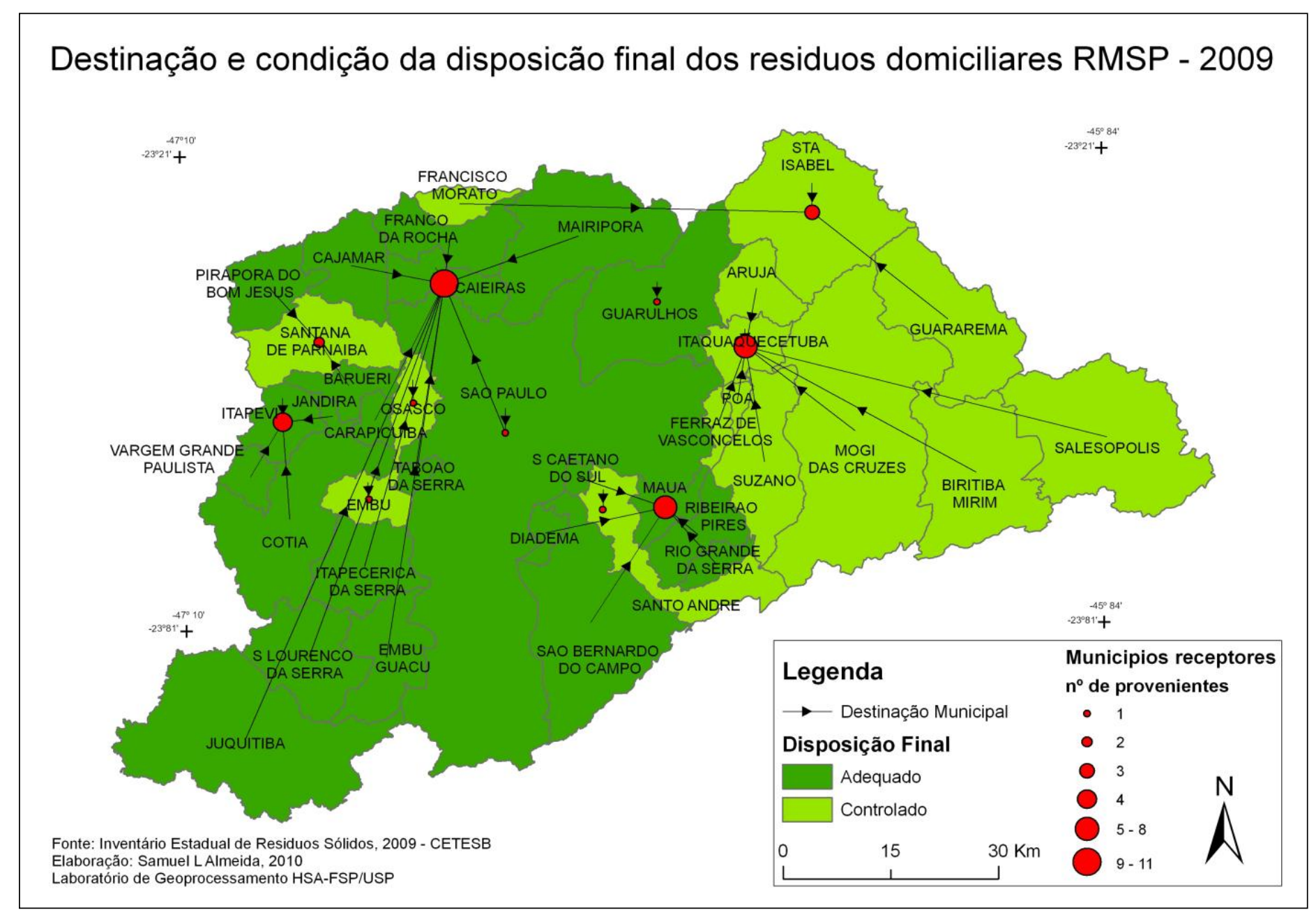


b) Evolução da coleta seletiva municipal

Constata-se a partir dos dados da pesquisa que houve ampliação da coleta seletiva municipal com inclusão socioprodutiva de organizações de catadores na RMSP, entre os anos de 2004 e 2010, com uma variação de 23 para 29 municípios. Destaca-se a ampliação dos municípios que praticam a coleta seletiva com organizações de catadores que variou de 19 para 28 municípios entre 2004 e 2010 (Figura 3). Apenas um município tem a coleta e triagem executada por empresa contratada e um realiza a coleta e doa o material reciclável para uma cooperativa sediada em outro município. Dentre os 10 municípios que não praticam a coleta seletiva, apenas um não tem projeto, seis municípios têm projeto de implantação com organizações de catadores e três ainda não definiram o modelo de coleta seletiva.

Figura 3 - Evolução de municípios com coleta seletiva e com organizações de catadores na RMSP, 2004 e 2010.

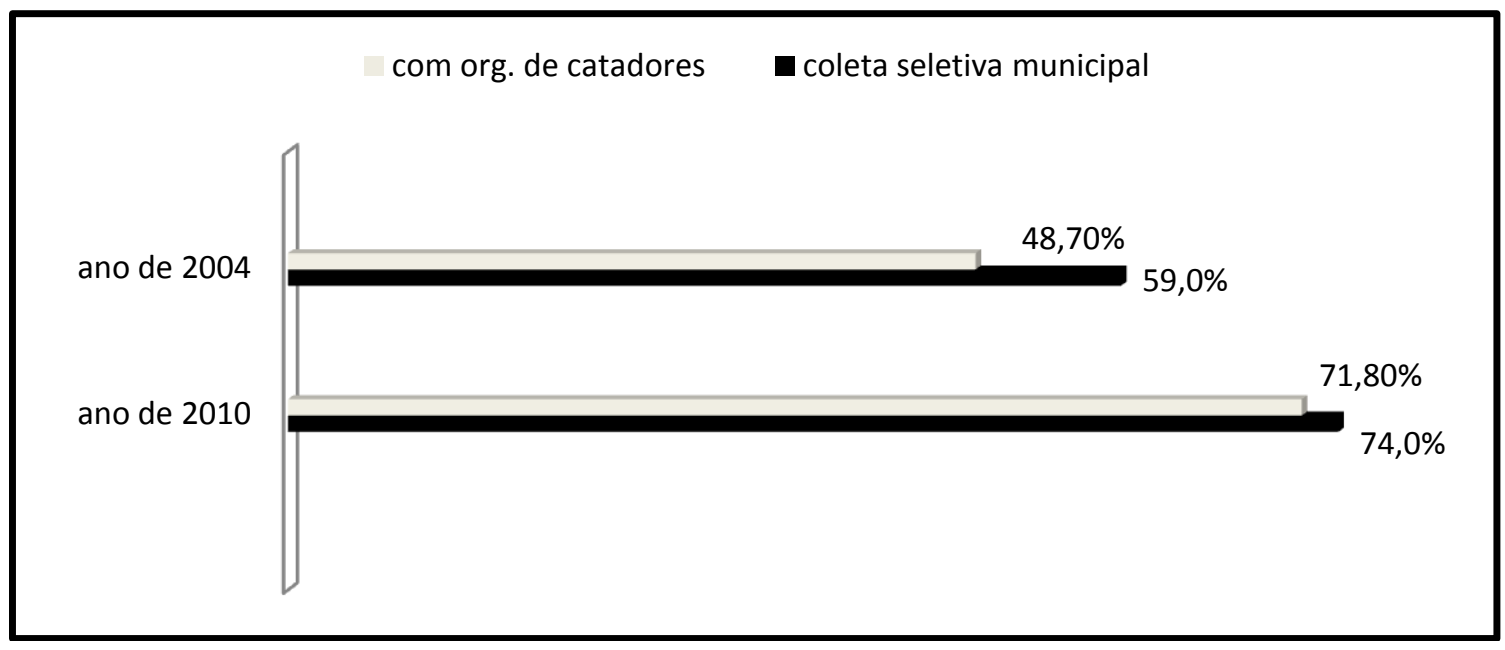

Elaborado pela autora a partir de informações das prefeituras municipais, março de 2010. 
Na RMSP, a coleta seletiva formal com organizações de catadores iniciou em 1989 na RMSP. Observa-se na Figura 4 uma concentração de municípios que implantaram a coleta seletiva, entre os anos de 2003 e 2005 e entre os anos de 2007 e 2009.

Figura 4 - Ano de inicio da coleta seletiva em 29 municípios da RMSP.

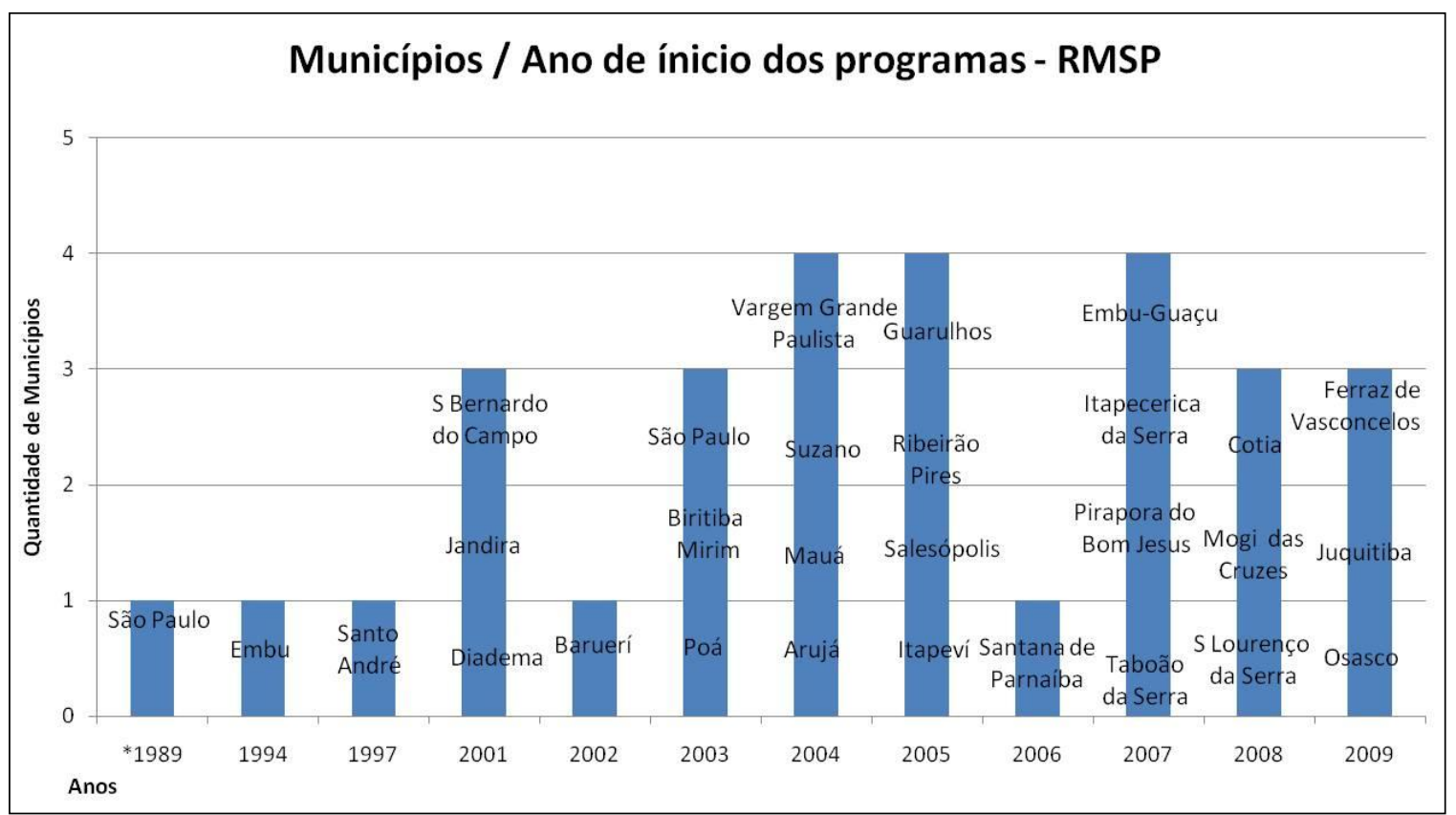

Elaborado pela autora a partir de informações das prefeituras municipais, março de 2010.

O município de São Paulo foi pioneiro, na implantação da coleta seletiva de RSU, em um projeto piloto em parceria com a Cooperativa de Catadores Autônomos de Papel, Papelão, Aparas e Materiais Reaproveitáveis (Coopamare) fundada em 1989. Houve descontinuidade administrativa e a 
coleta seletiva não foi ampliada, tendo sido retomada e ampliada no ano de 2003 (VIVEIROS, 2006).

Além da ampliação do número de municípios que prestam o serviço de coleta seletiva, entre os anos de 2004 e 2010, também se verifica o aumento significativo das quantidades de materiais recicláveis coletados e comercializados na RMSP (MAPAS 3 e 4).

No município de São Paulo a quantidade diária de materiais recicláveis comercializada aumentou de 470 toneladas para 3135 , crescimento de $576 \%$. Em 28 municípios da RMSP (excluindo São Paulo) a quantidade comercializada passou de 513 para $2.843,5$, crescimento de $454,3 \%$. Também se observa ampliação do número de municípios com cobertura de 100\% da área urbana; este número passou de um, no ano de 2005, para sete municípios, em 2010 (Tabela 4). Estes dados vêm ao encontro de resultados obtidos pelo CEMPRE que verificou a ampliação do número de municípios com cobertura de $100 \%$ da área urbana com coleta seletiva no país.

O município de São Paulo, com seus mais de 11 milhões de habitantes (2010), informou atender $20 \%$ de seu contingente populacional, ou cerca de 2,2 milhões de habitantes ${ }^{26}$.

É importante diferenciar os conceitos de cobertura e adesão. No primeiro caso embora o serviço de coleta seletiva seja oferecido, mesmo em $100 \%$ da área urbana, as taxas de adesão da população variam, e os municípios, em sua maioria, não possuem este dado. Daí a importância de se utilizar um indicador de adesão da população à coleta seletiva. Não foi possível estabelecer a comparação entre a cobertura em 2005 e 2010. Em 2005 o cálculo baseou-se em número estimado de habitantes. Em 2010, a maior parte dos respondentes não possuía este dado. Optou-se por coletar a informação em termos de cobertura de área municipal urbana, em alguns casos estimada pelos respondentes.

\footnotetext{
${ }^{26}$ Dois municípios não souberam informar: Ferraz de Vasconcelos e Itapecerica da Serra.
} 
MAPA 3 - Coleta seletiva em municípios da RMSP e quantidades comercializadas, 2004.

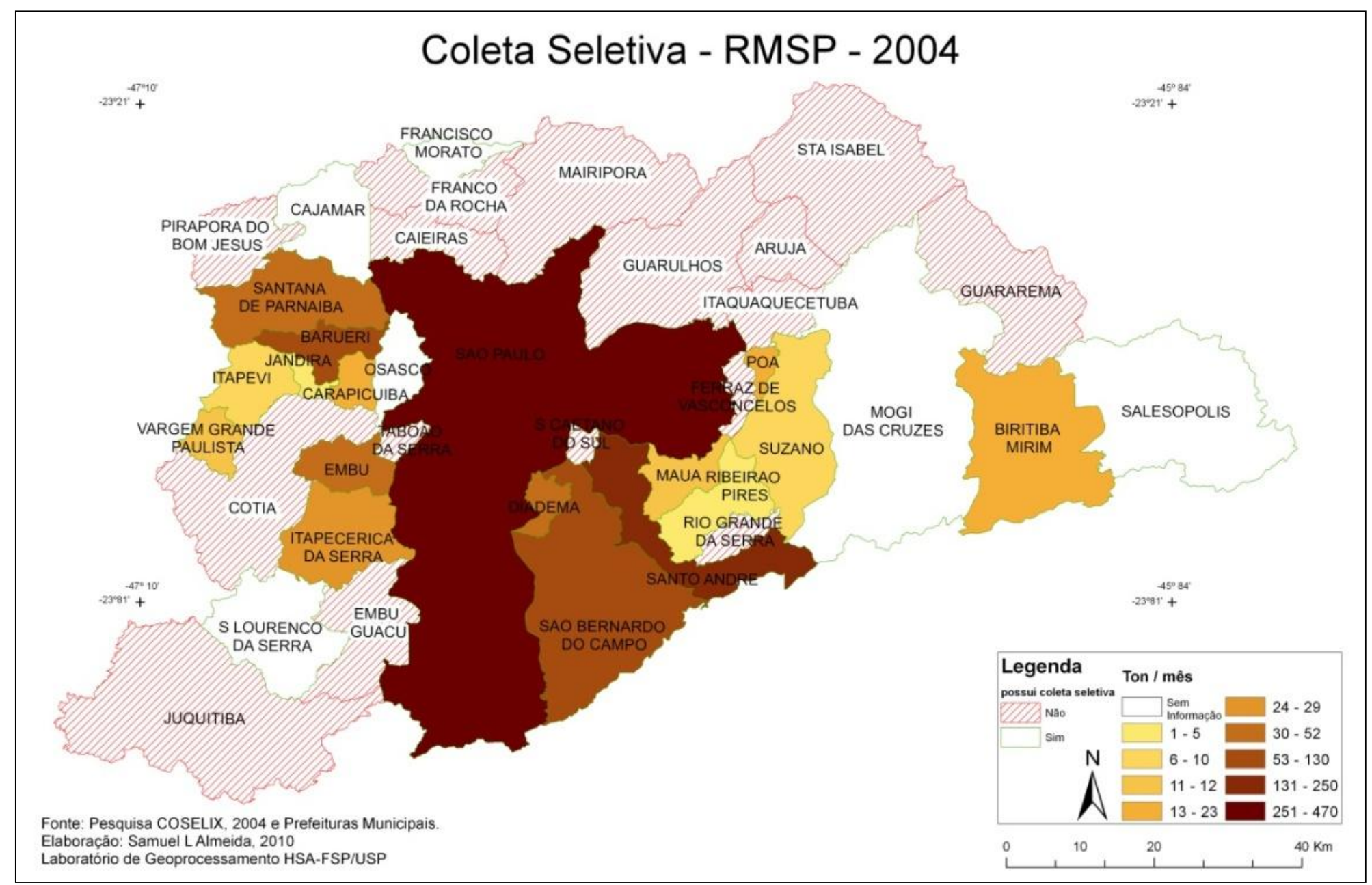


MAPA 4 - Coleta seletiva em municípios da RMSP e quantidades comercializadas, 2010.

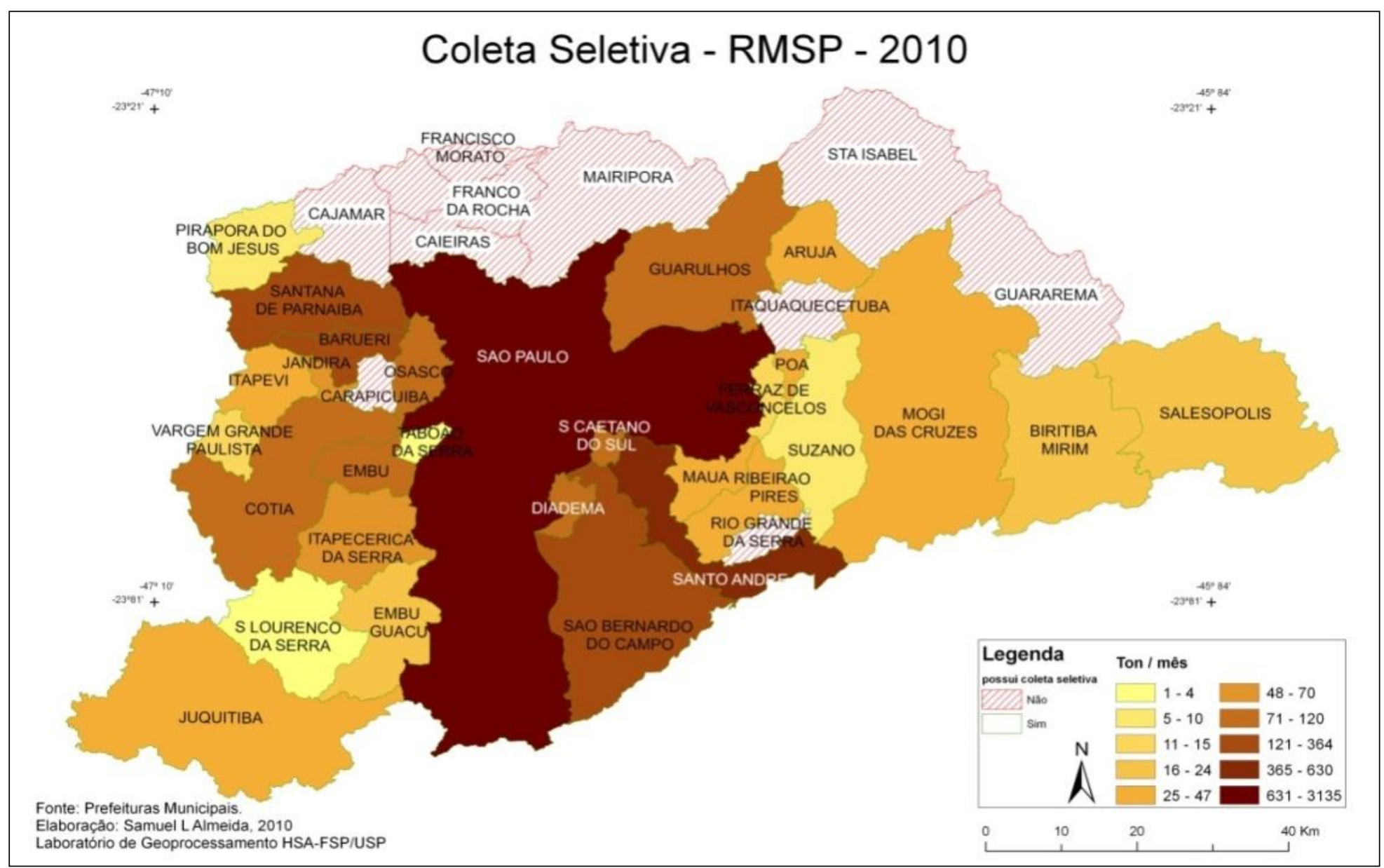


Considerando-se a importância da universalização e da equidade da prestação do serviço, verifica-se um déficit da coleta seletiva em vários municípios que já prestam o serviço há alguns anos, e atendem ainda uma pequena parcela dos habitantes.

Tabela 4 - Cobertura da coleta seletiva em municípios da RMSP, 2010.

\begin{tabular}{lc|c|c}
\hline \multicolumn{1}{c}{ Municípios } & $\begin{array}{c}\text { Cobertura } \\
\text { área urbana } \\
(\%)\end{array}$ & $\begin{array}{c}\text { Faixas de cobertura } \\
\text { área urbana } \\
(\%)\end{array}$ & $\begin{array}{c}\text { №. } \\
\text { Municípios }\end{array}$ \\
\hline Arujá & 100 & & \\
Barueri & 100 & & 7 \\
Salesópolis & 100 & 100 & \\
Santana do Parnaíba & 100 & & \\
Santo André & 100 & & \\
São Lourenço da S. & 100 & $60-99,9$ & \\
São Caetano do Sul & 100 & & \\
\hline Mogi das Cruzes & 80 & & \\
Juquitiba & 70 & $15,1-59,9$ & \\
São B. do Campo & 60 & & \\
\hline Diadema & 35 & & \\
Embu & 35 & & \\
Biritiba- Mirim & 35 & $10-15$ & \\
Poá & 35 & & \\
Osasco & 30 & & \\
Jandira & 30 & & \\
\hline Pirapora & 15 & & \\
Cotia & 10 & & \\
Embu- Guaçu & 10 & & \\
Itapevi & 10 & & \\
\hline Ribeirão Pires & 8 & & \\
Guarulhos & 6 & & \\
Vargem Grande & 6 & & \\
Taboão da Serra & 5 & & \\
Suzano & 3 & & \\
Mauá & 1 & & \\
\hline
\end{tabular}

Elaborado pela autora a partir de informações das prefeituras municipais, março de 2010. 
Para avaliar a quantidade de material que está sendo desviada dos aterros sanitários e encaminhada para reciclagem foi utilizada a taxa de recuperação de materiais recicláveis - $\mathrm{TRMR}^{27}$. Este indicador abrange várias dimensões da sustentabilidade, a ambiental, pelo desvio de materiais recicláveis do aterro e amplia a reciclagem, e o econômico. O aumento da TRMR representa maior quantidade de material encaminhado para a reciclagem e maiores ganhos sociais, pois mais material significa mais postos de trabalho e geração de renda.

Este é um dos mais importantes indicadores para a coleta seletiva, pois permite avaliar a eficiência do sistema. Também se configura em um importante indicador das condições de renda, e de melhoria ambiental, pois permite avaliar o desvio de resíduos recicláveis dos aterros sanitários. Em 2005, os resultados do desvio obtidos (RIBEIRO et al., 2009) variaram entre $0,21 \%$ e 3,02\%. Em 2010, os índices variaram de 0,2 a 17,2, destacando-se os municípios de Juquitiba (17,2 \%), Salesópolis (17,0\%), e Santana do Parnaíba (16,7\%), e seguindo-se Biritiba Mirim (7,4\%), Barueri (5,4\%), Santo André (4,9\%), e os demais com TRMR entre $0,4 \%$ e $3,4 \%$.

Em nove municípios foi possível comparar as taxas de recuperação de materiais recicláveis (TRMR) obtidos nos anos de 2005 e 2010. Embora os índices tenham aumentado significativamente, ainda podem ser considerados baixos, na maioria dos municípios (Tabela 5).

Cabe destacar o TRMR do município de Santana do Parnaíba, que evoluiu de 2,4\% para 16,7\%. VIEIRA e PINHEL (2009) aplicaram os indicadores de sustentabilidade da Pesquisa COSELIX na coleta seletiva municipal utilizando-o como instrumento de planejamento e monitoramento. Realizaram uma análise evolutiva da coleta seletiva no município neste

\footnotetext{
${ }^{27}$ Na pesquisa a nomenclatura do indicador Índice de recuperação de materiais recicláveis foi substituída por Taxa de recuperação de materiais recicláveis - TRMR para diferenciar dos índices de sustentabilidade da coleta seletiva e de organizações de catadores.
} 
município durante três anos tendo identificado uma ampliação gradual do grau de sustentabilidade.

Tabela 5 - Taxa de recuperação de materiais recicláveis em municípios da RMSP, 2005 e 2010.

\begin{tabular}{|l|c|c|}
\hline \multirow{2}{*}{ Municípios } & \multicolumn{2}{|c|}{ TRMR } \\
\cline { 2 - 3 } & $\mathbf{2 0 0 5}$ & $\mathbf{2 0 1 0}$ \\
\hline \multirow{2}{*}{ Barueri } & 3,0 & 5,7 \\
\hline Diadema & 0,2 & 2,0 \\
\hline Embu & 1,2 & 2,5 \\
\hline Itapecerica da Serra & 1,2 & 3,4 \\
\hline Poá & 1,1 & 3,2 \\
\hline Santana de Parnaíba & 2,4 & 16,7 \\
\hline Santo André & 1,5 & 4,9 \\
\hline S. Bernardo do Campo & 0,4 & 2,5 \\
\hline São Paulo & 0,7 & 1,1 \\
\hline
\end{tabular}

Elaborado pela autora a partir de informações das prefeituras municipais, março de 2010, e de RIBEIRO et al., 2009.

Observa-se o crescimento percentual significativo do TRMR e do número de membros das organizações. Por outro lado houve redução da renda média dos membros das organizações (Figura 5). Enquanto o percentual de crescimento da TRMR variou de $57 \%$ a $900 \%$, o de número de membros variou de $17 \%$ a quase $220 \%$ (APENDICE J). Entretanto apesar dos valores positivos 
destes indicadores, no que se refere à renda média dos membros das organizações de catadores, em apenas um município não houve queda, nos demais a queda variou entre $16 \%$ e $100 \%$.

Figura 5 - Variação da TRMR, número de membros e renda média, em salários mínimos, em municípios da RMSP, período 2005 - 2010.

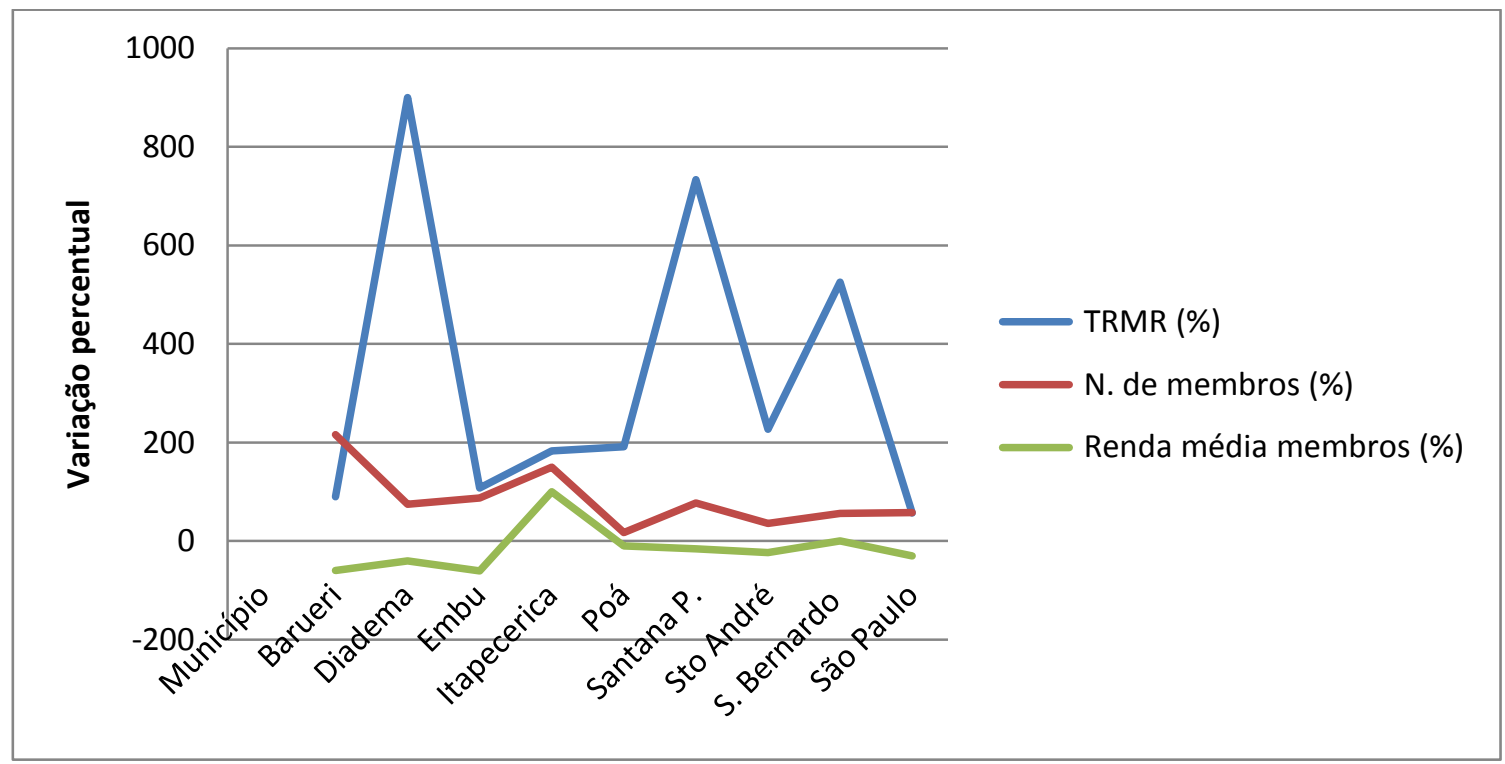

Elaborado pela autora a partir de informações das prefeituras municipais, março de 2010, e de RIBEIRO et al., 2009.

Segundo o MNCR a queda na renda dos catadores pode ser atribuída à crise econômica global dos anos de 2008 e 2009. Esta crise impactou o mercado de reciclagem e no Brasil, provocou uma queda média estimada em $62 \%$, no valor pago pelos materiais e a falência de centenas de organizações de catadores (IPEA, 2010). Ainda segundo o MNCR, além de afetar a renda familiar dos associados, dificultou o pagamento dos custos operacionais para realizar a coleta, pagar impostos e despesas administrativas. Em conseqüência, 
a maior parte dos associados deixou as organizações à procura de alternativas de trabalho, quase sempre informais. O preço dos recicláveis ainda se encontra em recuperação e os de alguns materiais não retornaram aos patamares anteriores a crise de 2008.

c) Características das organizações de catadores

Em 2010, foram identificadas 48 organizações de catadores atuando conjuntamente com 28 prefeituras na coleta seletiva; 39 (81\%) destas constituídas legalmente em cooperativas e 9 delas (19\%) em associações. Em 2005, havia 35 organizações parceiras de 18 municípios (15 de São Paulo).

No município de São Paulo 18 cooperativas atuam na coleta seletiva municipal, e nos demais 27 municípios da Região Metropolitana somam 30 organizações. Dentre os municípios, 22 (78,6\%) têm parceria com cooperativas, seis $(21,4 \%)$ com associações e dois $(14,3 \%)$ com ambas. Apenas um município tem parceria com um grupo de catadores não formalizado

Entre os anos de 2005 e 2010 houve crescimento de 66,5\% do número total de membros das organizações na RMSP, e um crescimento superior a $11 \%$ nos municípios, excetuando-se o de São Paulo, em relação ao registrado na RMSP (Tabela 6).

Quanto à evolução do número de membros das organizações desde o início, até 2010 (Apêndice K), verifica-se que de 16 municípios analisados, 12 apresentaram aumento; três mantiveram o número inicial de membros, e em apenas em um houve redução. $O$ Apêndice $L$ apresenta $0 n^{\circ}$ de organizações parceiras, número de membros, renda média por membro e quantidade média de recicláveis comercializada, em 2005 e 2010.

Com relação à renda média dos membros das organizações de catadores houve redução de 1,64 para 1,05 salários mínimos. A renda média, no ano de 2005, nos 11 municípios pesquisados, foi de $R \$ 427,00$, o 
equivalente a 1,64 salários mínimos (RIBEIRO et al., 2009). Em 2010, nos 28 municípios pesquisados, a renda média foi de $R \$ 537,00$, equivalente a 1,05 salários mínimos ${ }^{28}$.

Tabela 6 - Número de membros das organizações e percentual de crescimento em municípios da RMSP, 2005 e 2010.

Municípios da RMSP

Organizações de catadores

\begin{tabular}{cc}
\hline $\begin{array}{c}\text { Membros } \\
(\mathrm{N} .)\end{array}$ & $\begin{array}{c}\text { Crescimento } \\
(\%)\end{array}$ \\
\hline
\end{tabular}

2005

2010

28 municípios

1.327

2.210

66,5

27 municípios (exceto São Paulo)

662

1.161

75,4

São Paulo

645

1.049

62,6

Elaborado pela autora a partir de informações das prefeituras municipais, março de 2010, e de RIBEIRO et al., 2009.

Apenas dois municípios da RMSP remuneram as organizações de catadores pelo serviço prestado, Diadema e Biritiba Mirim. No primeiro a remuneração é realizada por tonelada coletada e no segundo por meio de convênio.

A produtividade dos membros das organizações variou entre $174 \mathrm{~kg} /$ mês e $4.286 \mathrm{~kg} /$ mês per capita no período. A média foi de $1.991 \mathrm{~kg} / \mathrm{mês}$. Em 13 municípios da RMSP a produtividade se encontra acima da média (APÊNDICE

\footnotetext{
${ }^{28}$ Levantamento feito pela autora em 2010. O valor do salário mínimo vigente, no período da entre dezembro de 2004 e maio de 2005 era $R \$ 260,00$, e em 2010 de $R \$ 510,00$.
} 
M). Para medir a eficiência do trabalho das cooperativas, utilizou-se o indicador de eficiência física ou produtividade média da produção física per capita, por cooperado, medida em kg/ mês O indicador foi desenvolvido no Estudo Análise do Custo de Geração de Postos de trabalho na economia urbana para o segmento dos catadores de materiais recicláveis (MNCR, 2006).

O estudo do MNCR, em 22 cooperativas do país, em 2006, apresentou a variação da produtividade entre $289 \mathrm{~kg} /$ mês e $2090 \mathrm{~kg} /$ mês. Estudo da CENTCOOP, em 2008, no Distrito Federal, com 14 organizações obteve a variação de $330 \mathrm{~kg} /$ mês a $2006 \mathrm{~kg} /$ mês, e a média de $1360 \mathrm{~kg} / \mathrm{mês}$.

\subsection{VALIDAÇÃO DE INDICADORES DE SUSTENTABILIDADE}

Apresenta- se nesse tópico os resultados do processo de validação de indicadores de sustentabilidade para a coleta seletiva e para as organizações de catadores, a partir da visão dos especialistas, por meio da aplicação da técnica Delphi.

Os seis indicadores de coleta seletiva submetidos à avaliação dos especialistas na 1aㅡ rodada do Delphi foram: 1) Sustentabilidade econômica, 2) Marco legal, 3) Parcerias, 4) Cobertura da coleta, 5) Índice de recuperação de materiais recicláveis, e 6) Índice de rejeito

Os doze indicadores de organizações de catadores submetidos à avaliação dos especialistas na 1a rodada do Delphi foram: 1) Regularização da organização, 2). Instrumento legal de parceria, 3) Rotatividade dos membros, 4) Capacitação dos membros, 5) Renda mensal por membro, 6) Participação dos membros, 7) Condição da instalação, 8) Equipamentos/veículos, 9) Horas trabalhadas dia/membro, 10) Benefícios aos membros, 11) Equipamentos de proteção individual, e 12) Parcerias. 
As respectivas tendências à sustentabilidade dos indicadores também foram avaliadas e estão apresentados nas págs 85 e 86 e no Apêndice B que apresenta o questionário da $1^{\underline{a}}$ rodada do Delphi.

\subsubsection{A visão dos especialistas: técnica Delphi}

Para atingir 0 objetivo proposto de validar indicadores de sustentabilidade de referência para a coleta seletiva e para as organizações de catadores foram aplicadas duas rodadas de avaliação.

$\mathrm{Na} 1^{\text {a }}$ rodada, dos 112 especialistas identificados, com atuação no país, 88 acusaram o recebimento da correspondência eletrônica e se dispuseram a participar da pesquisa. A taxa de retorno foi de 59 (67\%) questionários. Três questionários chegaram fora de prazo e não foram considerados.

Registraram-se 515 comentários e sugestões dos especialistas, das quais 25 consistiram em propostas de novos indicadores e seis em novos índices para a coleta seletiva municipal. Quanto às organizações de catadores foram propostos 27 novos indicadores e dois novos índices.

$\mathrm{Na} 2^{\text {a }}$ rodada foram enviados 59 questionários, 57 participantes acusaram o recebimento e 43 (72,9\%) retornaram. Dois questionários chegaram fora do prazo e não foram considerados.

Registraram-se 476 comentários e sugestões, e não se solicitou propostas de novos indicadores.

As duas rodadas totalizaram 991 comentários e sugestões que foram analisados e, quando considerados adequados, incorporados.

Os percentuais de abstenção obtidos nas duas rodadas de questionários, $33 \%$ na primeira rodada e $27,1 \%$ na segunda são condizentes com a literatura e, segundo WRIGHT e GIOVINAZZO (2000) apresentam uma abstenção de $30 \%$ a $50 \%$ na primeira rodada e de 20 a $30 \%$ na segunda. Outros autores que 
abordaram a validação de indicadores, no Brasil, obtiveram índices de $56 \%$ e $57 \%$ de retorno na primeira rodada (BRINGHENTI, 2004; PADILHA, 2009) ${ }^{29}$.

\subsubsection{Perfil dos especialistas}

Os especialistas atuam em 11 estados brasileiros. O Estado de São Paulo apresentou o maior número de respondentes (44,10\%), seguido por Minas Gerais (11,90\%), Distrito Federal e Rio de Janeiro (8,50\% cada um), Rio Grande do Sul e Espirito Santo (5,10\% cada um), Santa Catarina (3,40\%), e Paraná, Ceará e Bahia (1,70\% cada).

Residem em 22 cidades: São Paulo (28,8\%), Belo Horizonte (11,9\%), Brasília (11,9\%), Rio de Janeiro (11,9\%), Recife, Vitória e São Carlos $(5,1 \%$ cada), Florianópolis (3,4\%), Porto Alegre (3,4\%), e 1,7\% em cada uma das seguintes cidades: Americana, Campinas, Fortaleza, Ibiúna, Itupeva, Londrina, Salvador, Santo André, São Caetano do Sul, São Gabriel, Osnabruck (atual).

A amostra é composta por $58 \%$ do sexo feminino e $42 \%$ do sexo masculino. A faixa etária variou entre 24 e 64 anos, e está concentrada entre 45 e 49 anos. A profissão com maior número de respondentes é engenheiro (41, $4 \%$ ), seguida de biólogo (8,6\%), arquiteto, professor e sociologo com $6,9 \%$ cada um, geografo e assistente social com $5,2 \%$ cada um, economista $(3,4 \%)$, e as demais com $1,7 \%$ cada uma.

A maioria dos especialistas possui curso superior e $42,3 \%$ haviam cursado pós graduação,16,9\% mestrado, $23,7 \%$ doutorado,e $1,7 \%$ pós doutorado.

Embora o segmento de atuação não tenha sido um critério na escolha dos especialistas houve uma distribuição entre os diversos segmentos

\footnotetext{
${ }^{29}$ No caso de Padilha o retorno de $98 \%$ dos questionários, na segunda rodada, foi muito acima dos relatados na literatura.
} 
participantes, destacando-se os técnicos governamentais (federais, estaduais e municipais ) que totalizaram $34 \%$ da amostra (Figura 6).

Figura 6 - Distribuição dos especialistas por segmento de atuação.

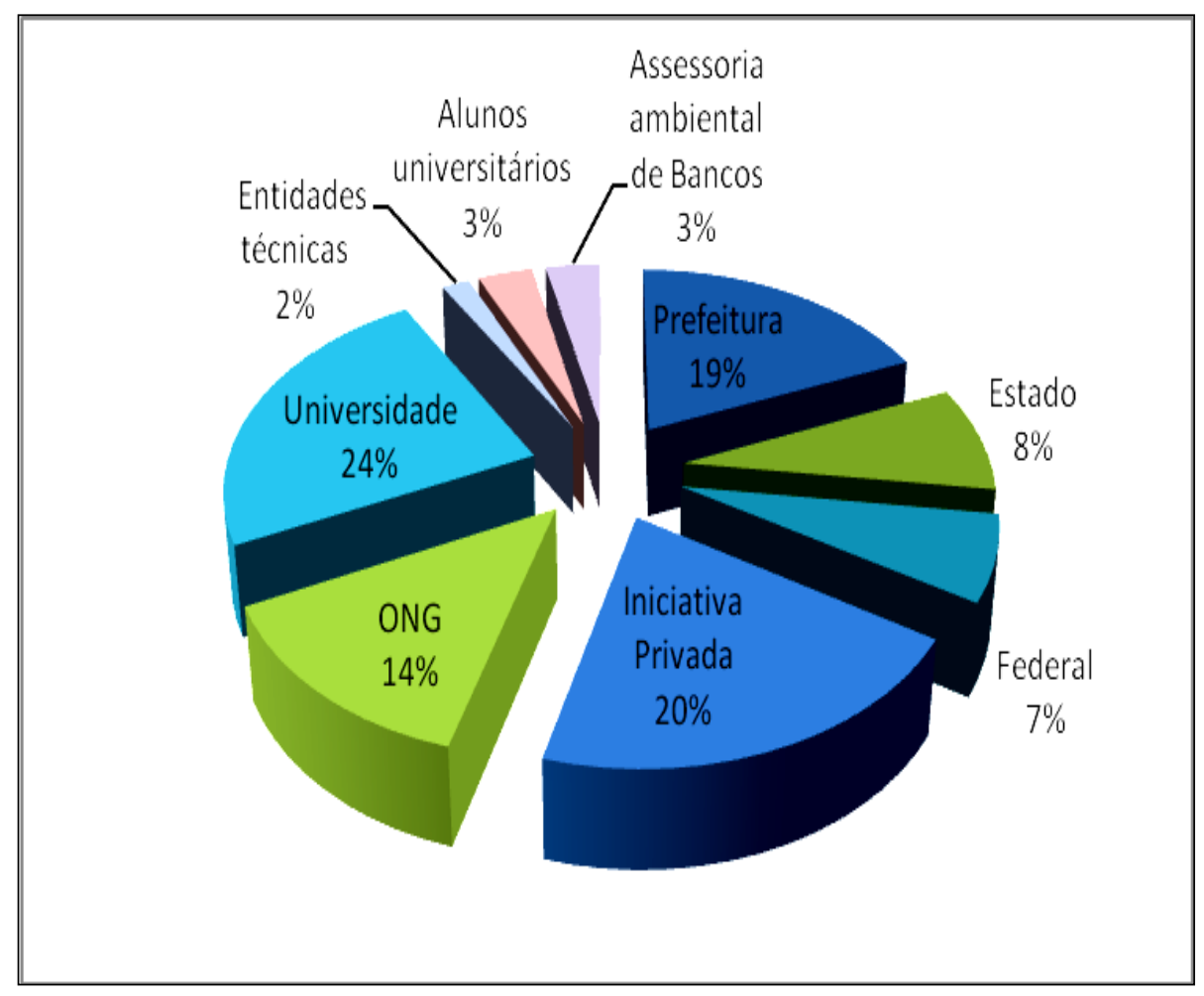

A experiência de trabalho com o tema varia de 1 a 29 anos, e a maioria trabalha há mais de 5 anos, portanto o grupo possui experiência.

\subsubsection{Avaliação das definições de sustentabilidade}

Quanto às definições de sustentabilidade da coleta seletiva e das organizações de catadores, avaliadas na 1 a rodada ( duas definições propostas na Pesquisa COSELIX, uma de coleta seletiva e uma de organizações de 
catadores) os especialistas se manifestaram (concordância, concordância parcial ou discordância) e justificaram a escolha. Observa-se que o grau de discordância, em ambos os casos foi muito baixo, houve uma quantidade significativa de sugestões para as definições, assim como um convergência com relação ao conteúdo (Tabela 7). Estas foram incorporadas e possibilitaram os resultados obtidos na $2^{\mathrm{a}}$ rodada.

$\mathrm{Na} 2^{\mathrm{a}}$ rodada, os especialistas escolheram entre duas definições de coleta seletiva e de organizações de catadores (ambas da pesquisa COSELIX) e duas novas definições formuladas pela pesquisadora, e que incorporaram várias observações dos especialistas.

Tabela 7 - Avaliação das definições de sustentabilidade de coleta seletiva e organizações de catadores, por especialistas, nas $1^{\underline{a}}$ e $2^{\underline{a}}$ rodadas do Delphi.

\begin{tabular}{|lccccc|}
\hline & \multicolumn{5}{c|}{ Avaliação dos especialistas } \\
\hline $\begin{array}{l}\text { Definições de } \\
\text { sustentabilidade }\end{array}$ & \multicolumn{4}{c|}{$\begin{array}{c}\text { 1ª rodada } \\
\text { (\%) }\end{array}$} & \multicolumn{2}{c|}{$\begin{array}{c}\text { 2a rodada } \\
(\%)\end{array}$} \\
\cline { 2 - 6 } & C & CP & D & Definição 1 & Definição 2 \\
\hline Coleta seletiva & 61,0 & 37,0 & 2,0 & 14,3 & 85,7 \\
\hline $\begin{array}{l}\text { Organizações } \\
\text { catadores }\end{array}$ & 55,9 & 40,7 & 3,4 & 4,7 & 95,3 \\
\hline
\end{tabular}

Notas: C- concorda CP- concorda parcialmente D- Discorda

As definições 2 de sustentabilidade da coleta seletiva e das organizações de catadores (Quadro 8) foram aprovadas. Quanto à coleta seletiva, o consenso se ampliou de $61 \%$ para $85,7 \%$. Em relação à sustentabilidade de organização de catadores o consenso foi ampliado de $55,9 \%$ para $95,3 \%$. 
Quadro 8 - Definições de sustentabilidade avaliadas por especialistas, nas $1^{\underline{a}} \mathrm{e}$ $2^{\mathrm{a}}$ rodadas do Delphi.

\begin{tabular}{|c|c|c|}
\hline \multicolumn{3}{|c|}{ Definições de sustentabilidade } \\
\hline \multirow{3}{*}{$\begin{array}{l}\text { Rodada } \\
\text { do } \\
\text { Delphi } \\
\qquad 1^{\mathbf{a}}\end{array}$} & Coleta seletiva & Organização de catadores \\
\hline & Definição 1 & Definição 1 \\
\hline & $\begin{array}{l}\text { Capacidade do município } \\
\text { desenvolver a coleta seletiva com } \\
\text { garantia legal e de recursos, e com a } \\
\text { meta de universalização dos serviços } \\
\text { e obtenção de resultados ambientais } \\
\text { e sociais crescentes. }\end{array}$ & $\begin{array}{l}\text { Capacidade da organização de } \\
\text { catadores de materiais recicláveis } \\
\text { desenvolver suas atividades, com a } \\
\text { garantia de regularização institucional } \\
\text { e a geração de trabalho e renda em } \\
\text { condições adequadas aos membros da } \\
\text { organização. }\end{array}$ \\
\hline \multirow[t]{2}{*}{$2^{\mathrm{a}}$} & Definição 2 & Definição 2 \\
\hline & $\begin{array}{l}\text { Capacidade do município desenvolver } \\
\text { a coleta seletiva de forma eficiente, } \\
\text { com garantia legal e de recursos } \\
\text { técnicos, a meta de universalização } \\
\text { dos serviços e obtenção de resultados } \\
\text { ambientais (educação ambiental } \\
\text { permanente e redução da disposição } \\
\text { em lixões e aterros), sociais (inclusão } \\
\text { social, gestão democrática e } \\
\text { participativa) e econômicos (recursos } \\
\text { de taxa ou do orçamento, geração de } \\
\text { renda e ampliação das atividades de } \\
\text { beneficiamento) crescentes. }\end{array}$ & $\begin{array}{l}\text { Capacidade da organização de } \\
\text { catadores de materiais recicláveis } \\
\text { desenvolver suas atividades, com a } \\
\text { garantia de: regularidade institucional, } \\
\text { autogestão (administrativa, financeira, } \\
\text { e organizacional) e a geração de } \\
\text { trabalho e renda em condições } \\
\text { adequadas de saúde pública e } \\
\text { segurança do trabalho aos membros } \\
\text { para atingir resultados sociais, } \\
\text { econômicos, e ambientais crescentes. }\end{array}$ \\
\hline
\end{tabular}

Nas duas rodadas, as discordâncias dos especialistas para a definição de sustentabilidade da coleta seletiva e de organizações de catadores priorizaram aspectos específicos. Estes discordaram do uso da expressão "resultados "crescentes" para definir sustentabilidade. As sugestões foram no sentido de substituir crescentes por "melhores" ou "mais adequados" ou "previstos nas metas". Alguns especialistas escolheram a definição 1 de coleta seletiva na $2^{2}$ rodada por considerá-la mais objetiva e concisa. 
No caso da definição de sustentabilidade das organizações de catadores, o nível de consenso foi menor na $1^{\underline{a}}$ rodada e aumentou significativamente na $2^{\mathrm{a}}$.

As observações dos especialistas na $1^{\underline{a}}$ rodada foram: 1) necessidade de inclusão do conceito de autogestão administrativa, financeira, organizacional; 2) inclusão da geração de trabalho e renda em condições adequadas de saúde pública e segurança do trabalho aos membros da organização; 3) inclusão de "para atingir resultados sociais, econômicos, e ambientais crescentes; e 4) substituir crescentes por: "mais adequados", "mais desejáveis", "previstos nas metas".

A sugestão de substituir "crescentes" não foi incorporada na $2^{\text {a }}$ rodada uma vez que "resultados crescentes" foram aceitos pela maioria dos especialistas, na $1^{\underline{a}}$ rodada. Apenas três participantes sugeriram esta alteração. As demais inclusões $(1,2,3)$ foram demandadas por grande parte dos que discordaram.

Vários autores argumentam quanto à dificuldade de conceituar a sustentabilidade assim como de medí-la (BELLEN, 2005; GUIMARÂES, 1997; 2009; VEIGA, 2005). No caso específico foi possível chegar a um alto nível de consenso quanto às duas definições, o que indica uma convergência no conceito de sustentabilidade da gestão tanto da coleta seletiva quanto de organizações de catadores.

\subsubsection{3 $1^{\underline{a}}$ rodada do Delphi}

$\mathrm{Na}$ primeira rodada foram avaliados 18 indicadores, seis referentes à coleta seletiva municipal e 12 das organizações de catadores, e suas respectivas tendências à sustentabilidade.

Segundo a avaliação dos especialistas foram atribuídas notas aos indicadores. Aqueles que atingiram o nível de 75\% de aprovação (notas 8, 9 e 
10) foram selecionados. Quando abaixo de $75 \%$, consideraram-se os comentários e sugestões para a não conformidade e a possibilidade de ajuste. Apenas o indicador 2 da coleta seletiva - Marco Legal, não foi aprovado.

$\mathrm{Na}$ Tabela 8 se apresenta a sistematização do número de indicadores mantidos, excluídos, alterados, propostos, incluídos, e selecionados para a $2^{\underline{a}}$ rodada. A partir de uma análise quali-quantitativa das propostas e comentários dos respondentes, complementadas com as contribuições obtidas nas oficinas realizadas em quatro cidades, os indicadores passaram de 6 , na $1^{\text {a }}$ rodada, para 14 , na $2^{\mathrm{a}}$ rodada.

Tabela 8- Seleção de indicadores de sustentabilidade de coleta seletiva da $1^{\underline{a}}$ para a $2^{\underline{a}}$ rodada do Delphi

\begin{tabular}{|c|c|c|c|c|c|c|}
\hline \multicolumn{7}{|c|}{ Número de Indicadores } \\
\hline $\begin{array}{c}1^{\mathrm{a}} \\
\text { Rodada }\end{array}$ & & & & & & $\begin{array}{c}2^{\mathrm{a}} \\
\text { Rodada }\end{array}$ \\
\hline $\begin{array}{c}\mathrm{N} . \\
\text { inicial }\end{array}$ & Mantidos & Excluídos & Alterados & Propostos & Incluídos & N. final \\
\hline 6 & 3 & 0 & 3 & 31 & 8 & 14 \\
\hline
\end{tabular}

Nas Figuras 7 e 8 apresentam-se os resultados da avaliação dos indicadores da coleta seletiva e das respectivas tendências à sustentabilidade (vide Tabela APÊNDICE N). 
Figura 7 - Avaliação de indicadores de sustentabilidade da coleta seletiva - $1^{\underline{a}}$ rodada do Delphi

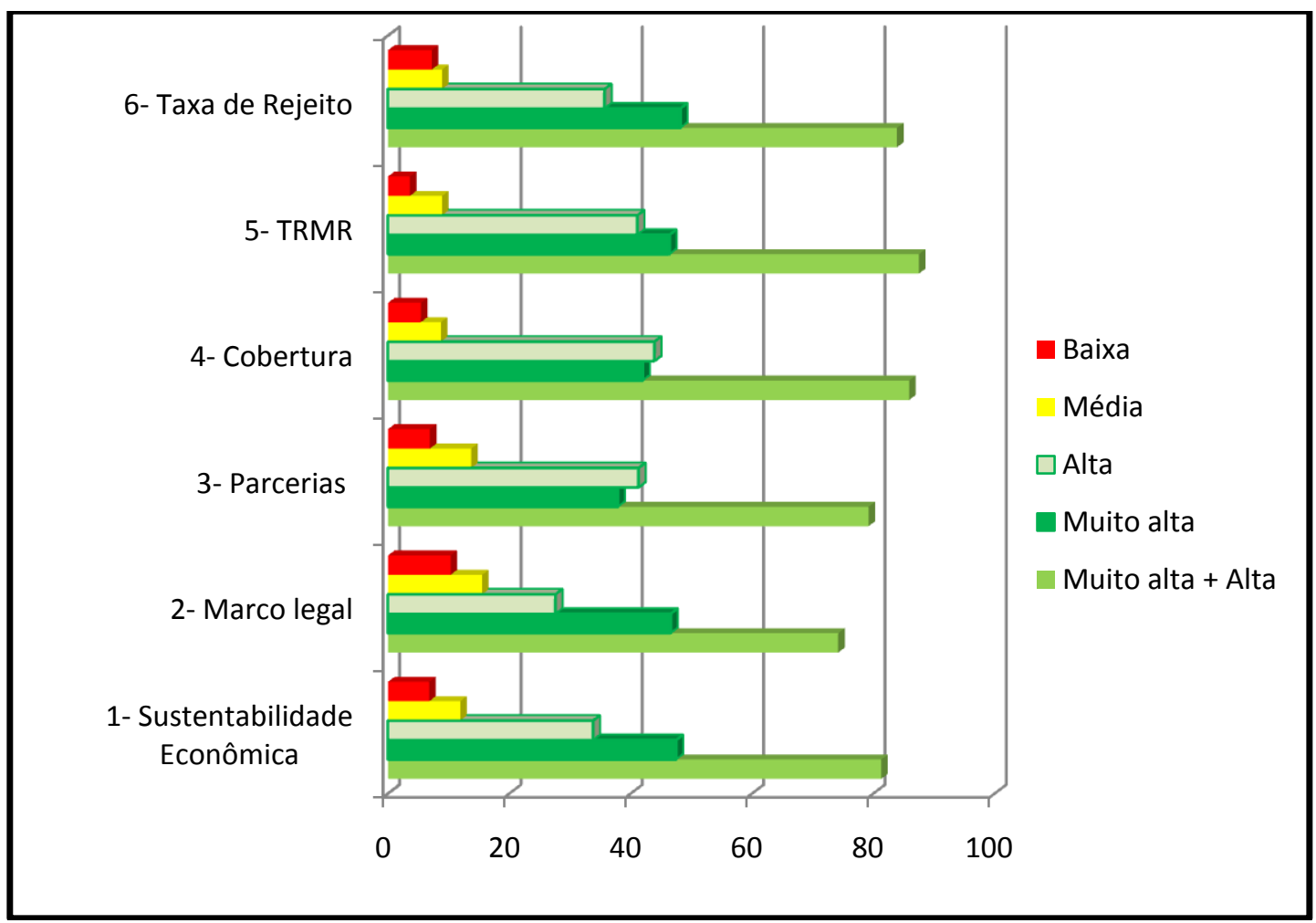

Percentual de notas: Muito alta $=10$ Alta $=9$ e $8 \quad$ Média $=6$ e 7 Baixa $=\leq 5$.

TRMR- Taxa de recuperação de materiais recicláveis =

Quantidade da coleta seletiva - Quantidade de rejeito $\quad \times 100$

Quantidade da coleta seletiva + Quantidade da coleta regular

TR- Taxa de Rejeito $=$

Quantidade da coleta seletiva - Quantidade da coleta seletiva comercializada $\times 100$ Quantidade da coleta seletiva

Embora houvesse consenso sobre a importância do indicador 3 Parceria, sua forma de medição foi questionada, e os especialistas sugeriram 
que as parcerias deveriam ser medidas a partir de sua qualidade, diversidade e sua contribuição econômica e social para a sustentabilidade. Portanto o indicador foi alterado para a $2^{\underline{a}}$ rodada.

Figura 8 - Avaliação de tendências à sustentabilidade da coleta seletiva, $1^{\text {a }}$ rodada do Delphi.

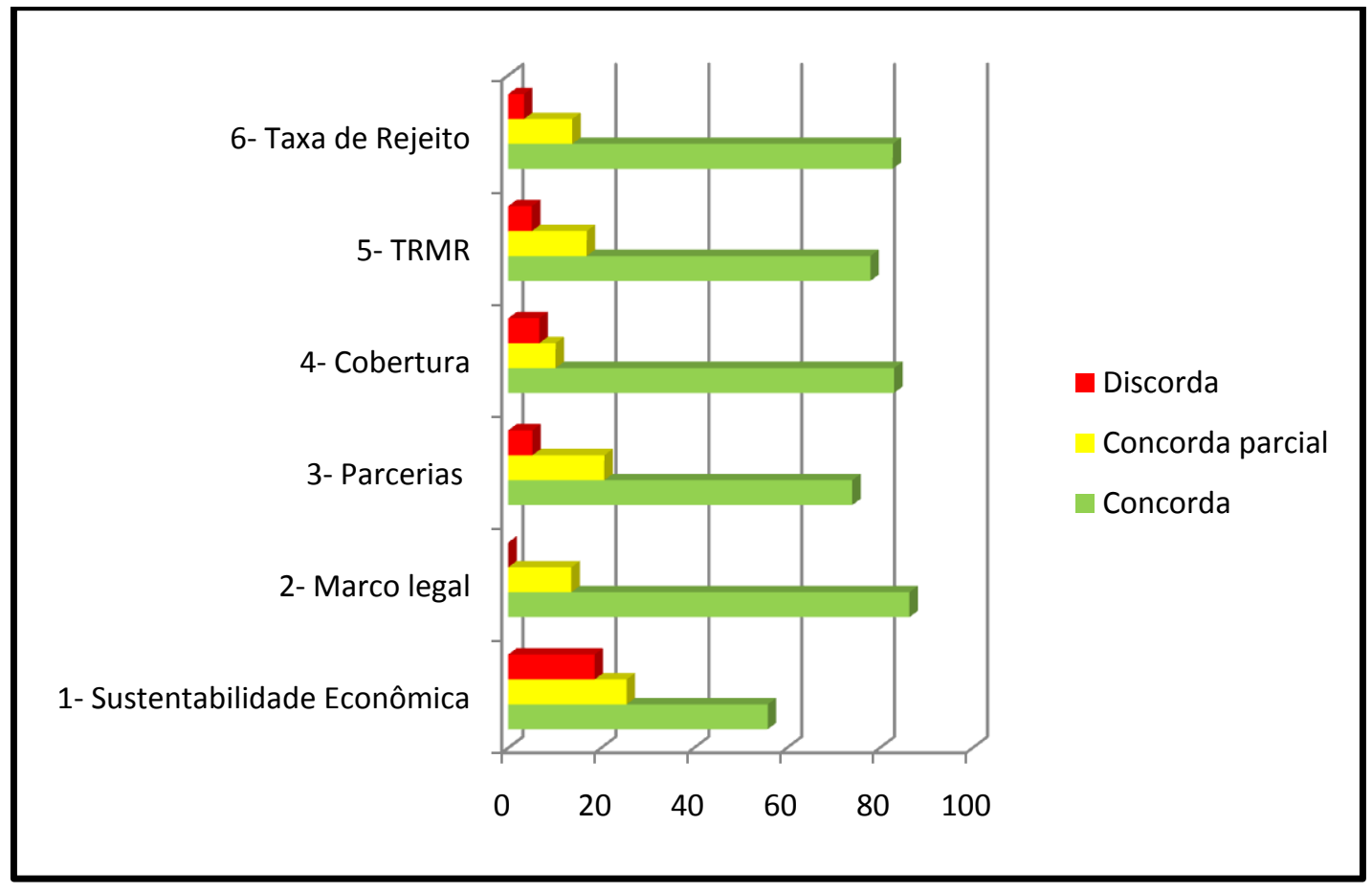

Percentual de notas: Muito alta $=10$ Alta $=9$ e 8 Média $=6$ e 7 Baixa $=\leq 5$.

As Figuras 9 e 10 apresentam o resultado da avaliação dos 12 indicadores das organizações de catadores e suas respectivas tendências à sustentabilidade, na $1 \stackrel{a}{ }$ rodada. 
Figura 9 - Avaliação de indicadores de sustentabilidade de organizações de catadores -1 a rodada do Delphi

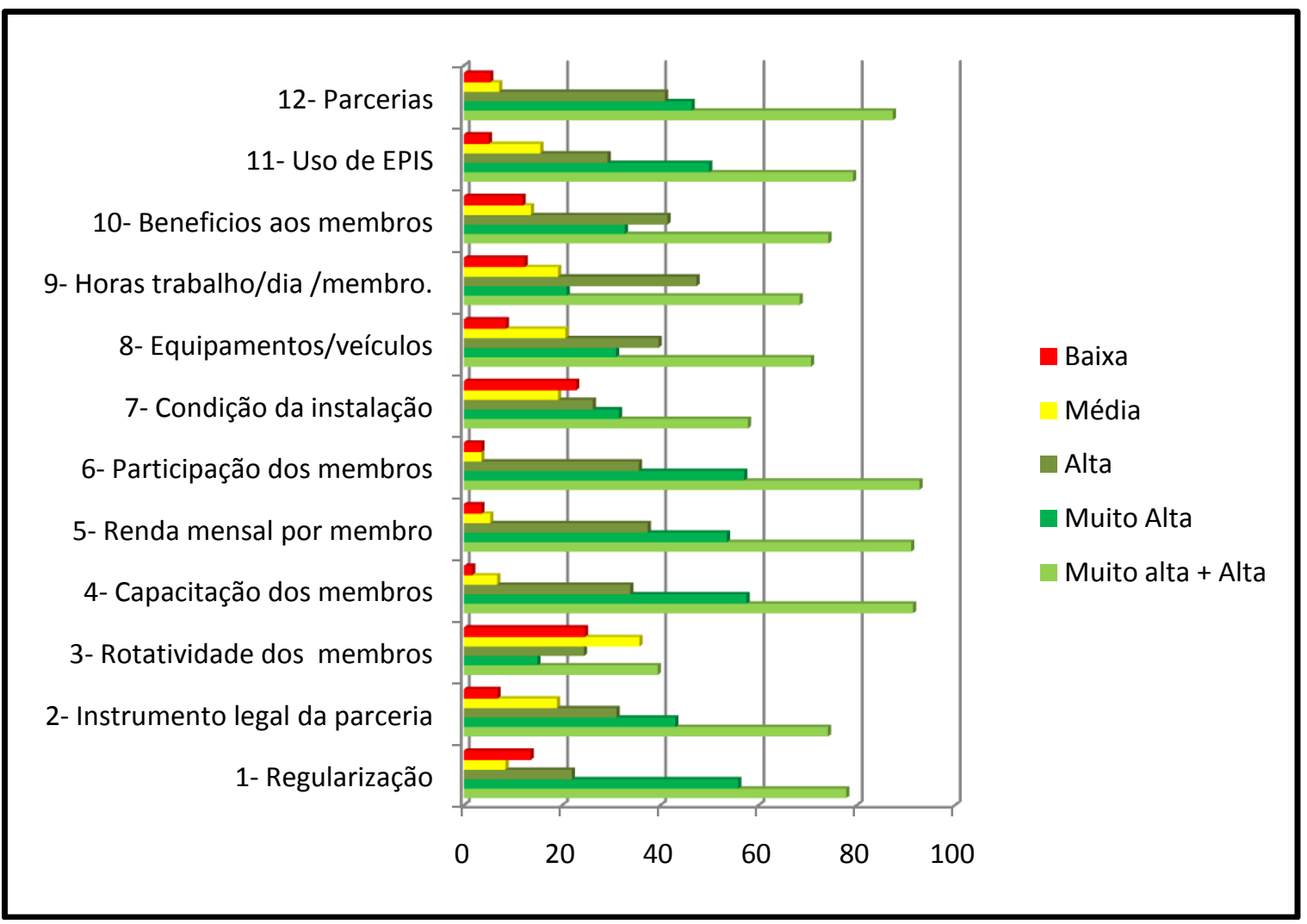

Percentual de notas: Muito alta $=10$ Alta $=9$ e 8 Média $=6$ e 7 Baixa $=\leq 5$.

Em relação aos indicadores de sustentabilidade (Figura 9), sete indicadores se mantiveram (Ind.1, Ind.2, Ind.3, Ind.6, Ind.8, Ind.10 e Ind.11), tendo os demais sido alterados para a segunda rodada. O único indicador excluído foi o Indicador 7- Condição da instalação considerado inadequado em sua construção. O Indicador 3- Rotatividade foi mantido, porém seu cálculo modificado para uma nova análise, pois apesar de considerado muito importante as notas a ele atribuídas foram baixas. 
Figura 10- Avaliação de tendências à sustentabilidade de indicadores das organizações de catadores - $1^{a}$ rodada do Delphi.

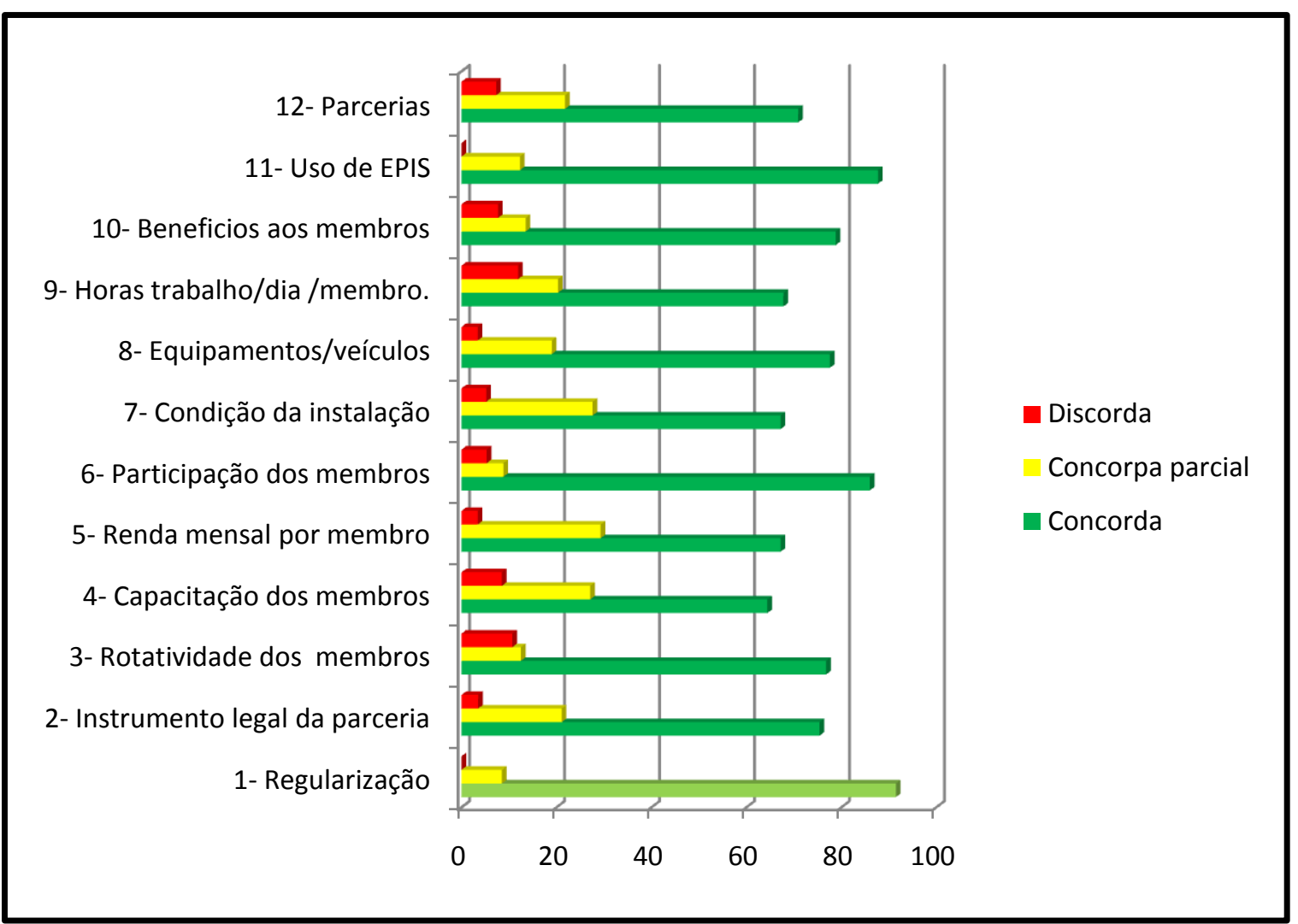

Percentual de notas: Muito alta $=10$ Alta $=9$ e 8 Média $=6$ e 7 Baixa $=\leq 5$.

Realizou-se também uma análise quali-quantitativa das propostas e comentários dos respondentes, complementadas com as observações colhidas nas oficinas regionais. Os indicadores passaram de 12, na primeira rodada, para 18 na segunda.

A Tabela 9 apresenta o número de indicadores mantidos, excluídos, alterados, propostos, incluídos, e selecionados para a $2^{\text {a }}$ rodada do Delphi. 
Tabela 9 - Seleção de indicadores de sustentabilidade de organizações de catadores da $1^{\text {a }}$ para a $2^{\underline{a}}$ rodada do Delphi.

\begin{tabular}{|c|c|c|c|c|c|c|}
\hline \multicolumn{7}{|c|}{ Número de Indicadores } \\
\hline $\begin{array}{c}1^{\mathrm{a}} \\
\text { Rodada }\end{array}$ & & & & & & $\begin{array}{c}2^{\mathrm{a}} \\
\text { Rodada }\end{array}$ \\
\hline $\begin{array}{c}\mathrm{N} . \\
\text { inicial }\end{array}$ & Mantidos & Excluídos & Alterados & Propostos & Incluídos & N. final \\
\hline 12 & 8 & 1 & 3 & 29 & 7 & 18 \\
\hline
\end{tabular}

$\mathrm{Na} 1^{\underline{a}}$ rodada, os especialistas, assim como os participantes das oficinas regionais consideraram que os indicadores de Parcerias, da coleta seletiva (Ind. 3) e das organizações de catadores (Ind. 12) eram muito importantes e representativos, porém insatisfatórios da forma como foram construídos, pois consideraram inadequado medir a tendência à sustentabilidade a partir do número de parcerias. Também sugeriram a construção de novos índices que contemplassem outras variáveis.

Entretanto, como não havia consenso sobre as variáveis que comporiam os novos índices, as fórmulas de cálculo e as "tendências à sustentabilidade"; a pesquisadora optou por construir indicadores que pudessem ser representativos do conjunto de variáveis que poderiam ser contempladas no caso da construção de futuros índices. Estes foram os casos dos indicadores, 3 e 10 (Parcerias e Condições de trabalho) da coleta seletiva, como também dos indicadores 3, 4, 5, 16 e 17 (Qualidade das parcerias, Diversificação de parcerias, Diversificação das atividades e serviços, Atendimento aos requisitos de saúde no trabalho e Atendimento aos requisitos de segurança e salubridade do trabalho) das organizações de catadores. Destaca-se também o cuidado em não selecionar ou formular indicadores cujas informações fornecidas pelo indicador não possibilitaria adotar medidas de correção em áreas específicas da gestão (BELLEN, 2005). 


\subsubsection{Segunda rodada do Delphi}

Na segunda rodada Delphi, os especialistas avaliaram 32 indicadores, 14 referentes à coleta seletiva municipal e 18 às organizações de catadores, assim como suas respectivas fórmulas de cálculo, tendências à sustentabilidade e cinco características dos indicadores. Os resultados da avaliação dos indicadores da coleta seletiva estão apresentados nas Tabelas 10 e 11.

A maioria dos indicadores da coleta seletiva obteve uma avaliação positiva. Os indicadores avaliados receberam notas que variaram entre $41,5 \% \mathrm{e}$ $90,7 \%$ de alta e muito alta (8, 9, e 10). Excetuando-se o indicador 3- Parcerias que obteve um percentual de $41,5 \%$, os demais variaram numa faixa de $54,7 \%$ a $90,7 \%$.

Destacam-se os indicadores que obtiveram mais de $70 \%$ de notas altas e muito altas: Ind. 1- Atendimento da população (82\%), Ind. 2- Adesão da população (90,7\%), Ind.7- Instrumentos legais na relação com as org. de catadores (71,8\%), Ind. 8- Índice de recuperação de recicláveis (86\%), Ind. 9 Índice de rejeito (80,5\%), Ind.10- Condições de trabalho (78\%), e Ind. 14- Custo da coleta seletiva/coleta regular + aterro $(76,2 \%)$.

Quanto às avaliações das fórmulas de cálculo dos indicadores, verificamse resultados acima de $52,5 \%$ de concordância. As discordâncias se concentraram em: Ind. 3 - Parcerias (17,5\%), Ind. 4- Educação e divulgação $(24,4 \%)$, Ind. 5- Gestão compartilhada (14,6\%), e Ind. 11- Autofinanciamento $(19 \%)$.

$\mathrm{Na}$ avaliação das tendências à sustentabilidade dos indicadores resultou que todos os indicadores obtiveram acima de $50 \%$ de grau de concordância. Os indicadores que foram avaliados obtiveram a concordância de $61 \%$ a $93 \%$. Os seguintes indicadores obtiveram um percentual maior de discordâncias: Ind.3. Parcerias (22,5\%), Ind. 4-Educação e divulgação (17,1\%), Ind.6- Inclusão de 
catadores avulsos (19,5\%), Ind. 12- Custo da coleta/ manejo de resíduos sólidos (17,5\%), Ind. 18-Custo da coleta seletiva/coleta regular + aterro $(15,4 \%)$.

Embora os especialistas tenham destacado que o indicador de Parcerias é importante, as análises qualitativas mostraram que houve um alto grau de discordância com a forma de medição proposta e várias sugestões de construção de um índice de parcerias.

A maioria dos indicadores das organizações de catadores obteve uma avaliação positiva (Tabela 11). As notas altas e muito altas (8,9 e 10) variaram de $46,2 \%$ a 97,7\%. Excetuando-se o indicador de diversificação de parcerias $(46,2 \%)$ todos os demais obtiveram acima de $50 \%$.

Destacam-se os seguintes indicadores: Ind.7-Participação (83,7\%), Ind.8Capacitação (80,9\%), Ind.11- Renda média (97,7\%), Ind. 17 - Atendimento aos requisitos de segurança e salubridade do trabalho (88\%), Ind. 18 - Uso de equipamentos de proteção individual (85,4\%), Ind. 1 - Regularização $(78,6 \%)$, Ind. 2- Instrumentos legais na relação com a prefeitura $(76,1 \%)$, Ind. 12 Produtividade do catador (79\%) e Ind. 17 - Atendimento aos requisitos de saúde no trabalho $(78,6 \%)$.

As avaliações das fórmulas de cálculo dos indicadores obtiveram acima de $57,5 \%$ de concordância. Os seguintes indicadores obtiveram um percentual maior de discordâncias: Ind. 3 - Qualidade das Parcerias (23,1\%), Ind. 4Diversificação das Parcerias (25\%) e Ind. 9. Rotatividade (14,6\%).

Da avaliação das tendências à sustentabilidade dos indicadores resultou que todos os indicadores obtiveram acima de $73,8 \%$ de concordância. O indicador que obteve o maior percentual de discordâncias foi o Ind. 13. Equipamentos e veículos próprios/cedidos (16,7\%). 
Tabela 10 - Avaliação de indicadores de sustentabilidade de coleta seletiva, respectivas fórmulas de cálculo e tendências à sustentabilidade $-2^{\underline{a}}$ rodada do Delphi

\begin{tabular}{|c|c|c|c|c|c|c|c|c|c|c|c|c|c|c|}
\hline \multicolumn{15}{|c|}{ Indicadores de sustentabilidade da coleta seletiva } \\
\hline \multirow{3}{*}{ Indicadores } & \multirow[t]{3}{*}{$\mathbf{V}$} & & & & & & V & & & & $\mathbf{V}$ & & & \\
\hline & & \multicolumn{5}{|c|}{$\begin{array}{c}\text { Nota do indicador } \\
(\%)\end{array}$} & & \multicolumn{3}{|c|}{$\begin{array}{c}\text { Fórmula } \\
(\%)\end{array}$} & & \multicolumn{3}{|c|}{$\begin{array}{c}\text { Tendência à } \\
\text { sustentabilidade } \\
(\%)\end{array}$} \\
\hline & & $M A+A$ & MA & $\mathbf{A}$ & $\mathbf{M}$ & B & & C & CP & D & & $\mathbf{C}$ & $\mathrm{CP}$ & D \\
\hline 1. Atendimento da população & 43 & 82,0 & 65,1 & 20,9 & 9,4 & 4,6 & 43 & 88,4 & 11,6 & 0,0 & 43 & 93,0 & 7,0 & 0,0 \\
\hline 2. Adesão da população & 43 & 90,7 & 51,2 & 39,5 & 9,3 & 0,0 & 41 & 80,5 & 17,1 & 2,4 & 43 & 79,1 & 18,6 & 2,3 \\
\hline 3. Parcerias efetivas/desejáveis ${ }^{30}$ & 42 & 41,5 & 12,2 & 29,2 & 26,9 & 31,6 & 40 & 52,5 & 30,0 & 17,5 & 40 & 70,0 & 7,5 & 22,5 \\
\hline 4. Educação /divulgação & 42 & 69,2 & 23,8 & 45,3 & 19,0 & 11,9 & 41 & 58,5 & 17,1 & 24,4 & 41 & 68,3 & 14,6 & 17,1 \\
\hline 5. Gestão compartilhada & 42 & 54,7 & 23,8 & 30,9 & 28,6 & 16,7 & 41 & 58,6 & 26,8 & 14,6 & 42 & 81,0 & 14,3 & 4,8 \\
\hline 6. Inclusão de catadores avulsos & 42 & 61,9 & 23,8 & 38,1 & 21,4 & 16,7 & 41 & 70,7 & 17,1 & 12,2 & 41 & 61,0 & 19,5 & 19,5 \\
\hline $\begin{array}{l}\text { 7.Instrumentos legais na relação com as } \\
\text { organizações. }\end{array}$ & 39 & 71,8 & 41,0 & 30,8 & 18,0 & 10,3 & 40 & 77,5 & 15,0 & 7,5 & 40 & 80,0 & 15,0 & 5,0 \\
\hline 8. Taxa de recuperação de materiais recicláveis & 43 & 86,0 & 48,8 & 37,3 & 11,6 & 2,3 & 42 & 88,1 & 11,9 & 0,0 & 43 & 76,7 & 16,3 & 7,0 \\
\hline
\end{tabular}

${ }^{30}$ Organizações de catadores, redes de catadores, setor público estadual ou federal, setor privado, organizações não governamentais, organizações comunitárias, entidades representativas dos catadores. 


\begin{tabular}{|c|c|c|c|c|c|c|c|c|c|c|c|c|c|c|}
\hline \multicolumn{15}{|c|}{ Continuação - Indicadores de sustentabilidade da coleta seletiva } \\
\hline \multirow{3}{*}{ Indicadores } & V & & & & & & V & & & & V & & & \\
\hline & & \multicolumn{5}{|c|}{$\begin{array}{l}\text { Nota do indicador } \\
(\%)\end{array}$} & & \multicolumn{3}{|c|}{$\begin{array}{c}\text { Fórmula } \\
\text { (\%) }\end{array}$} & & \multicolumn{3}{|c|}{$\begin{array}{c}\text { Tendência à } \\
\text { sustentabilidade } \\
(\%)\end{array}$} \\
\hline & & $\mathrm{MA}+\mathrm{A}$ & MA & A & $\mathbf{M}$ & B & & $\mathbf{C}$ & $\mathbf{C P}$ & D & & C & $\mathbf{C P}$ & D \\
\hline 9. Taxa de rejeito & 41 & 80,5 & 43,9 & 36,6 & 14,7 & 4,8 & 43 & 83,7 & 9,3 & 7,0 & 43 & 76,7 & 11,6 & 11,6 \\
\hline 10. Condições de trabalho ${ }^{31}$ & 41 & 78,0 & 26,8 & 51,2 & 19,6 & 2,4 & 42 & 73,8 & 16,7 & 9,5 & 42 & 76,2 & 14,3 & 9,5 \\
\hline 11. Autofinanciamento & 40 & 60,0 & 27,5 & 32,5 & 22,5 & 17,5 & 42 & 57,1 & 23,8 & 19,0 & 40 & 70,0 & 25,0 & 5,0 \\
\hline 12. Custo da coleta/ manejo de RS & 40 & 65,0 & 27,5 & 37,5 & 22,5 & 12,5 & 39 & 82,1 & 15,4 & 2,6 & 40 & 62,5 & 20,0 & 17,5 \\
\hline 13. Custo da seletiva / quantidade seletiva ${ }^{32}$ & 43 & 69,8 & 32.6 & 37,2 & 20,9 & 9,3 & 41 & 82,9 & 17,1 & 0,0 & 40 & 72,5 & 15,0 & 12,5 \\
\hline 14. Custo da coleta seletiva/coleta regular + aterro ${ }^{33}$ & 42 & 76,2 & 33,3 & 42,9 & 11,9 & 11,9 & 40 & 80,0 & 15,0 & 5,0 & 39 & 71,8 & 12,8 & 15,4 \\
\hline
\end{tabular}

Notas: $\mathrm{MA}=$ muito alta $=$ nota $10 ; \mathrm{A}=$ alta $=$ notas 8 e $9 ; \mathrm{m}=$ Média $=$ notas 6 e $7 ; \mathrm{B}=$ baixa $=$ de 0 a 5 .

$\mathrm{V}=\mathrm{n}$. de questionários válidos.

Fórmulas e tendências à sustentabilidade: $\mathrm{C}=$ concorda, $\mathrm{CP}=$ concorda parcialmente, $\mathrm{D}=$ discorda

${ }^{31}$ Recomendam-se o atendimento aos requisitos do Ministério da Saúde e Trabalho: Princípios de higiene e limpeza, controle de vetores de doenças, ausência de ratos, moscas e baratas, cobertura adequada, ventilação adequada, ausência de odores incômodos, sistema de prevenção de riscos acidentes e incêndios, plano de emergência, uso de EPIS, identificação de materiais perigosos, e outros.

${ }^{32}$ O valor de $\mathrm{R} \$ 175,00 / \mathrm{t}$ foi considerado viável e baixo para a coleta seletiva a partir dos seguintes cálculos: $R \$ 72,00 / t$ é o valor médio para a coleta convencional apurado pelo SNIS 2006 (R $\$ 61,32 / \mathrm{t}$.) e reajustado em 17,5\% (agosto de 2008 pelo IGPm). Considerando-se que a coleta convencional tenha um valor de $R \$ 72,00 / t$ (SNIS, 2006), e a disposição em aterro sanitário de $R \$ 45,00 / t$ o valor total é de $\mathrm{R} \$ 117,00 /$ t. Considerando-se ainda que os ganhos ambientais e sociais assumam um valor de $50 \%$ deste total chega-se ao valor indicativo da coleta seletiva de $\mathrm{R} \$ 175,00 /$ t. como adequado.

${ }^{33}$ Segundo o SNIS 2006, a coleta regular representa um percentual médio de $36,8 \%$ do custo do manejo de resíduos sólidos municipais. Se atribuído um valor aproximado de $15 \%$ para o aterramento chega- se a um índice médio de $50 \%$ que se aproxima do percentual que as prefeituras gastam com coleta e aterramento. O cálculo não inclui as externalidades e outros ganhos de difícil mensuração. 
Tabela 11 - Avaliação de indicadores de sustentabilidade de organizações de catadores, respectivas fórmulas de cálculo e tendências à sustentabilidade - $2^{2}$ rodada do Delphi.

\begin{tabular}{|c|c|c|c|c|c|c|c|c|c|c|c|c|c|c|}
\hline \multicolumn{15}{|c|}{ Indicadores de sustentabilidade das organizações de catadores } \\
\hline & V & & & & & & V & & & & V & & & \\
\hline & & \multicolumn{5}{|c|}{ Nota do indicador (\%) } & & \multicolumn{3}{|c|}{ Fórmula (\%) } & & \multicolumn{3}{|c|}{$\begin{array}{c}\text { Tendência à } \\
\text { sustentabilidade \% }\end{array}$} \\
\hline & & $\mathbf{M A}+\mathrm{A}$ & MA & $\mathbf{A}$ & M & B & & $\mathbf{C}$ & $\mathbf{C P}$ & D & & $\mathbf{C}$ & $\mathbf{C P}$ & D \\
\hline 1. Regularização & 42 & 78,6 & 31,0 & 47,6 & 16,6 & 4,8 & 41 & 92,7 & 4,9 & 2,4 & 40 & 85,0 & 12,5 & 2,5 \\
\hline $\begin{array}{l}\text { 2. Instrumentos legais na relação com a } \\
\text { prefeitura }\end{array}$ & 42 & 76,1 & 42,9 & 33,2 & 19,1 & 4,8 & 41 & 90,2 & 2,4 & 7,4 & 42 & 88,1 & 9,5 & 2,4 \\
\hline 3. Qualidade das parcerias/desejáveis ${ }^{34}$ & 38 & 52,6 & 18.4 & 34,2 & 29,0 & 18,4 & 39 & 61,5 & 15,4 & 23,1 & 40 & 80,0 & 7,5 & 12,5 \\
\hline $\begin{array}{l}\text { 4. Diversificação de parcerias/ } \\
\text { desejáveis }\end{array}$ & 39 & 46,2 & 10,3 & 35,9 & 25,7 & 28,1 & 40 & 57,5 & 17,5 & 25,0 & 41 & 75,6 & 12,2 & 12,2 \\
\hline $\begin{array}{l}\text { 5. Diversificação das atividades e } \\
\text { serviços }^{36}\end{array}$ & 40 & 52,5 & 22,5 & 30,0 & 25,0 & 22,5 & 42 & 69.0 & 16,7 & 14.3 & 41 & 85,4 & 7,3 & 7,3 \\
\hline $\begin{array}{l}\text { 6. Atendimento aos requisitos de } \\
\text { autogestão }\end{array}$ & 41 & 65,9 & 34,2 & 31,7 & 26,9 & 7,4 & 42 & 76.2 & 19,0 & 4,8 & 42 & 88,1 & 7,1 & 4,8 \\
\hline 7. Participação dos membros em reuniões & 43 & 83,7 & 39,5 & 44,2 & 11,6 & 4,7 & 42 & 95,2 & 2,4 & 2,4 & 43 & 88,4 & 7,0 & 4,7 \\
\hline 8. Membros capacitados & 42 & 80,9 & 38.1 & 42,8 & 7,2 & 11,9 & 41 & 78,0 & 14,6 & 7,3 & 40 & 85,0 & 12,5 & 2,5 \\
\hline
\end{tabular}

\footnotetext{
${ }^{34}$ Capacitação, alfabetização, cessão de equipamentos, cessão de espaço, material de educação e comunicação, ações de educação e comunicação cessão de materiais recicláveis, apoio técnico, construção de galpão de triagem.

${ }^{35}$ Setor público municipal, estadual, federal, setor privado, organizações não governamentais, redes de organizações de catadores, catadores avulsos, entidades representativas dos catadores.

${ }^{36}$ Educação ambiental, coleta, triagem, beneficiamento, reaproveitamento de materiais recicláveis, reciclagem, prestação de serviços a terceiros.

${ }^{37}$ Reuniões de decisão auto-gestionária, regimento interno, instrumentos de transparência e rateio: informações sobre despesas, descontos, vendas e rateio, livros disponíveis, murais de comunicação e informação.
} 


\begin{tabular}{|c|c|c|c|c|c|c|c|c|c|c|c|c|c|c|}
\hline \multicolumn{15}{|c|}{ Continuação - Indicadores de sustentabilidade das organizações de catadores } \\
\hline & $\mathbf{V}$ & & & & & & $\mathbf{V}$ & & & & $\mathbf{V}$ & & & \\
\hline & & \multicolumn{5}{|c|}{ Nota do indicador (\%) } & & \multicolumn{3}{|c|}{ Fórmula (\%) } & & \multicolumn{3}{|c|}{$\begin{array}{c}\text { Tendência à } \\
\text { sustentabilidade (\%) }\end{array}$} \\
\hline & & MA+A & MA & A & $\mathbf{M}$ & $\mathbf{B}$ & & $\mathbf{C}$ & CP & $\mathbf{D}$ & & $\mathbf{C}$ & CP & D \\
\hline 9. Rotatividade & 40 & 65,0 & 30,0 & 35,0 & 27,5 & 7,5 & 41 & 70,8 & 14,6 & 14,6 & 39 & 76,9 & 12,8 & 10,3 \\
\hline 10. Benefícios ${ }^{38}$ & 40 & 62,5 & 35,0 & 27,5 & 22,5 & 15,0 & 42 & 71,4 & 14,3 & 14,3 & 41 & 78,0 & 14,6 & 7,3 \\
\hline 11. Renda média mensal membro/ s.m. & 43 & 97,7 & 65,1 & 32,6 & 2,3 & - & 41 & 92,7 & 7,3 & - & 43 & 88,4 & 11,6 & - \\
\hline 12. Produtividade catador/mês & 43 & 79,0 & 37,2 & 41,8 & 14,0 & 7,0 & 38 & 86,8 & 10,5 & 2,6 & 38 & 73,7 & 23,7 & 2,6 \\
\hline 13. Equipamentos e veículos & 40 & 57,5 & 32,5 & 25,0 & 22,5 & 2,0 & 42 & 76,2 & 9,5 & 14,3 & 42 & 73,8 & 9,5 & 16,7 \\
\hline 14. Horas trabalhadas & 41 & 65,8 & 29,3 & 36,5 & 17,1 & 17,1 & 42 & 76,2 & 11,9 & 11,9 & 40 & 77,5 & 10,0 & 12,5 \\
\hline 15. Relação de ganhos entre gêneros & 42 & 57,1 & 26,2 & 30,9 & 16,6 & 26.3 & 42 & 71,4 & 16,7 & 11,9 & 41 & 78,0 & 12,2 & 9,8 \\
\hline 16. Saúde no trabalho ${ }^{39}$ & 42 & 78,6 & 50,0 & 28,6 & 14,3 & 7,1 & 41 & 80,5 & 12,2 & 7,3 & 42 & 81,0 & 11,9 & 7,1 \\
\hline 17. Segurança e saúde do trabalho ${ }^{40}$ & 42 & 88,0 & 52,4 & 35,6 & 2,4 & 9,6 & 42 & 76,2 & 14,3 & 9,5 & 41 & 82,9 & 14,6 & 2,4 \\
\hline 18. Uso de equipamentos de EPI & 41 & 85,4 & 39,0 & 46,4 & 7,3 & 7,3 & 41 & 73,2 & 19,5 & 7,3 & 39 & 76,9 & 17,9 & 5,1 \\
\hline
\end{tabular}

Notas: $\mathrm{MA}=$ muito alta= nota $10 ; \mathrm{A}=$ alta $=$ notas 8 e $9 ; \mathrm{M}=$ média $=$ notas 6 e $7 ; \mathrm{B}=$ baixa $=$ de 0 a 5 .

$\mathrm{V}=\mathrm{n}$. de questionários válidos. Cálculo e tendências à sustentabilidade: $\mathrm{C}=$ concorda, $\mathrm{CP}=$ concorda parcialmente, $\mathrm{D}=$ discorda

${ }^{38}$ Férias remuneradas, afastamento maternidade, prêmios, convenio, curso de alfabetização, transporte, creche, licença remunerada, conta bancária.

${ }^{39}$ Vacinação regular, prevenção de LER - lesão por esforços repetitivos, descanso pelo peso das atividades, limpeza e higiene no local de trabalho, exames médicos periódicos, comunicação visual nos ambientes, alimentação adequada, recolhimento de INSS pelos cooperados, prevenção, registro e atendimento aos acidentes de trabalho, notificação de doenças transmissíveis.

${ }^{40}$ Rotina de limpeza, controle de vetores de doenças; ratos, moscas e baratas, cobertura adequada, ventilação adequada, ausência de odores incômodos, sistema de prevenção de acidentes e incêndios. 
Nessa rodada foi solicitada a avaliação de cinco características dos 14 indicadores da coleta seletiva, representatividade, comparabilidade, coleta de dados, clareza e síntese, e previsão e metas (Tabela 12).

Tabela 12 - Avaliação de características de indicadores de sustentabilidade de coleta seletiva - $2^{\mathrm{a}}$ rodada do Delphi

\begin{tabular}{|c|c|c|c|c|c|}
\hline \multicolumn{6}{|c|}{ Indicadores de sustentabilidade de coleta seletiva } \\
\hline & \multicolumn{5}{|c|}{ Características (\%) } \\
\hline & $\begin{array}{l}\text { Represen- } \\
\text { tatividade }\end{array}$ & $\begin{array}{l}\text { Compara- } \\
\text { bilidade }\end{array}$ & $\begin{array}{l}\text { Coleta } \\
\text { de } \\
\text { dados }\end{array}$ & $\begin{array}{c}\text { Clareza } \\
e \\
\text { síntese }\end{array}$ & $\begin{array}{c}\text { Previsão } \\
\text { e } \\
\text { metas }\end{array}$ \\
\hline Ind.1 Atendimento da população & 97.7 & 90.7 & 79,1 & 81,4 & 86,0 \\
\hline Ind.2 Adesão da população & 95,3 & 86,0 & 67,4 & 72,1 & 72,1 \\
\hline Ind.3 Parcerias & 48,8 & 39,5 & 48,8 & 37,2 & 41,9 \\
\hline Ind.4 Educação e divulgação & 74,4 & 48,8 & 58,1 & 62,8 & 62,8 \\
\hline Ind.5 Gestão compartilhada & 81.4 & 48.8 & 46.5 & 41.9 & 58.1 \\
\hline $\begin{array}{l}\text { Ind.6 Inclusão de catadores } \\
\text { avulsos }\end{array}$ & 69.0 & 61.9 & 38.1 & 50.0 & 59.5 \\
\hline Ind.7 Instrumentos legais & 74.4 & 51.2 & 62.8 & 53.5 & 60.5 \\
\hline Ind.8 TRMR & 93.0 & 83.7 & 76.7 & 79.1 & 90.7 \\
\hline Ind.9 Taxa de rejeito-IR & 90.7 & 83.7 & 76.7 & 74.4 & 79.1 \\
\hline Ind.10 Condições de trabalho & 76.7 & 48.8 & 60.5 & 58.1 & 74.4 \\
\hline Ind.11 Autofinanciamento & 66.7 & 57.1 & 57.1 & 52.4 & 69.0 \\
\hline $\begin{array}{l}\text { Ind. } 12 \text { Custo da coleta seletiva/ } \\
\text { manejo de resíduos }\end{array}$ & 74.4 & 74.4 & 69.8 & 69.8 & 67.4 \\
\hline $\begin{array}{l}\text { Ind. } 13 \text { Custo da coleta seletiva/ } \\
\text { quantidade da coleta seletiva }\end{array}$ & 83.7 & 81.4 & 72.1 & 74.4 & 74.4 \\
\hline $\begin{array}{l}\text { Ind.14 Custo da coleta seletiva/ } \\
\text { coleta regular e aterramento }\end{array}$ & 81.4 & 76.7 & 74.4 & 72.1 & 74.4 \\
\hline
\end{tabular}


Segundo a avaliação da maioria dos especialistas, com relação às características dos 14 indicadores; 9 deles (Inds. 1, 2, 7, 8, 9, 11, 12, 13 e 14) apresentaram as 5 características (verde), 4 não atenderam a todas as características (Inds. 4, 5, 6 e 10) (amarelo), e apenas o Ind. 3- Parcerias não atendeu a nenhuma característica (vermelho).

$\mathrm{Na} 2^{\text {a }}$ rodada também foi solicitada a avaliação de cinco características com relação aos 18 indicadores das organizações de catadores (Tabela 13).

Tabela 13- Avaliação de características de indicadores de sustentabilidade de organizações de catadores- $2^{2}$ rodada do Delphi

\section{Indicadores de sustentabilidade de organizações de catadores}

\begin{tabular}{lccccc}
\hline & \multicolumn{5}{c}{ Características (\%) } \\
\cline { 2 - 6 } & $\begin{array}{c}\text { Represen- } \\
\text { tatividade }\end{array}$ & $\begin{array}{c}\text { Compara- } \\
\text { bilidade }\end{array}$ & $\begin{array}{c}\text { Coleta } \\
\text { de } \\
\text { dados }\end{array}$ & $\begin{array}{c}\text { Clareza } \\
\text { e } \\
\text { síntese }\end{array}$ & $\begin{array}{c}\text { Previsão } \\
\text { e } \\
\text { metas }\end{array}$ \\
\hline 1. Regularização & 86.0 & 69.8 & 60.5 & 67.4 & 72.1 \\
2. Instrumentos legais & 86.0 & 74.4 & 72.1 & 60.5 & 72.1 \\
\hline 3. Qualidade das parcerias & 60.5 & 48.8 & 46.5 & 39.5 & 55.8 \\
\hline 4. Diversificação de & 55.8 & 37.2 & 53.5 & 34.9 & 44.2 \\
parcerias & & & & & \\
5. Atividades e serviços & 74.4 & 48.8 & 65.1 & 46.5 & 65.1 \\
6. Autogestão & 88.4 & 55.8 & 48.8 & 51.2 & 65.1 \\
7. Participação em reuniões & 83.7 & 74.4 & 72.1 & 72.1 & 62.8 \\
8. Membros capacitados & 86.0 & 69.8 & 65.1 & 60.5 & 74.4 \\
9. Rotatividade & 76.7 & 79.1 & 69.8 & 74.4 & 65.1 \\
10. Benefícios & 69.8 & 55.8 & 65.1 & 55.8 & 69.8 \\
11. Renda média mensal & 95.3 & 88.4 & 83.7 & 79.1 & 93.0 \\
12. Produtividade por & 79.1 & 74.4 & 72.1 & 67.4 & 69.8 \\
catador & & & & & \\
13. Equipamentos e veículos & 53.5 & 62.8 & 69.8 & 53.5 & 58.1 \\
14. Horas trabalhadas & 78.6 & 64.3 & 66.7 & 59.5 & 66.7 \\
15. Ganhos entre gêneros & 58.1 & 72.1 & 74.4 & 60.5 & 65.1 \\
16. Saúde no trabalho & 90.7 & 72.1 & 65.1 & 60.5 & 67.4 \\
17. Segurança e salubridade & 93.0 & 74.4 & 67.4 & 62.8 & 69.8 \\
18. Uso de EPIS & 86.0 & 69.8 & 58.1 & 53.5 & 65.1 \\
\hline
\end{tabular}


Segundo a avaliação da maioria, em relação às características dos indicadores referentes às organizações de catadores: do total de 18, 14 (Inds. $1,2,7,8,9,10,11,12,13,14,15,16,17,18)$ possuíam as cinco características (verde), enquanto 4 não atenderam a todas as características (Inds. 3, 4, 5, e 6) (amarelo). O indicador 6-Autogestão deixou de atender a apenas uma característica (amarelo).

O conjunto de indicadores avaliados mede processos importantes para a sustentabilidade ambiental, social, econômica e institucional da coleta seletiva.

Nos quadros 9 e 10 apresentam-se os indicadores da coleta seletiva, e das organizações de catadores, na ordem de importância a eles atribuida pelos especialistas e os principais processos e dimensões da sustentabilidade (ambiental, econômica, social e politico-institucional) abrangidas.

Ressalta-se que a saúde enfocada na perspectiva dos seus determinantes sociais está contemplada nas quatro dimensões da sustentabilidade.

Destaca-se que os indicadores de sustentabilidade propostos, no geral medem mais de uma dimensão de sustentabilidade. Conforme afirma Milanez (2002), baseando-se em vários autores (DOYLE et al., 1997; TYLER NORRIS ASSOCIATES et al., 1997; WARREN, 1997; MEADOWS, 1998; SUSTAINABLE SEATTLE, 1998; BOSSEL, 1999, HARGET e MEYER apud BELL \& MORSE, 1999), "os indicadores precisam ser capazes de fazer ligações ou relações entre os diferentes elementos das distintas dimensões da sustentabilidade".

No caso dos indicadores selecionados, com a exceção de um único indicador, os demais abrangem de duas a três dimensões da sustentabilidade. Cabe destacar que os dois indicadores mais bem avaliados da coleta seletiva abrangem as quatro dimensões da sustentabilidade.

Nesse sentido a organização de grupos de indicadores da pesquisa não se dá em função das dimensões da sustentabilidade que abarca, mas em relação aos temas que integram a gestão sustentável de resíduos sólidos. 
Quadro 9 - Indicadores de coleta seletiva, processos e dimensões da sustentabilidade abrangidas.

\section{Indicadores de sustentabilidade da coleta seletiva}

\begin{tabular}{|c|c|c|c|}
\hline & Indicadores & Processo & $\begin{array}{l}\text { Dimensões da } \\
\text { sustentabilidade }\end{array}$ \\
\hline 1 & Adesão & $\begin{array}{l}\text { a) Efetividade da coleta seletiva - Quantas residências } \\
\text { participam, em relação às residências atendidas. } \\
\text { b) Eficiência do processo de educação e comunicação } \\
\text { Quanto mais eficiente é o processo de educação feito } \\
\text { pelas instituições, maior é a participação. } \\
\text { c) Participação- A coleta seletiva é voluntária e } \\
\text { depende essencialmente da participação dos } \\
\text { munícipes. } \\
\text { d) Resultados ambientais - quanto maior adesão, } \\
\text { maior a quantidade de material desviado do aterro e } \\
\text { reciclado. }\end{array}$ & $\begin{array}{l}\text { Social } \\
\text { Econômica } \\
\text { Institucional } \\
\text { Ambiental }\end{array}$ \\
\hline 2 & $\begin{array}{l}\text { Taxa de recuperação } \\
\text { de recicláveis }\end{array}$ & $\begin{array}{l}\text { a) Eficiência do sistema de coleta seletiva } \\
\text { b) Desvio do reciclável do aterro } \\
\text { c) Ganhos: ambientais, economicos e sociais }\end{array}$ & $\begin{array}{l}\text { Ambiental } \\
\text { Social } \\
\text { Econômica } \\
\text { Institucional }\end{array}$ \\
\hline 3 & $\begin{array}{l}\text { Cobertura do } \\
\text { Atendimento }\end{array}$ & $\begin{array}{l}\text { a) Universalização do serviço } \\
\text { b) Justiça social }\end{array}$ & $\begin{array}{l}\text { Social } \\
\text { Institucional } \\
\text { Ambiental }\end{array}$ \\
\hline 4 & Taxa de Rejeito & Eficiência da separação na fonte e na triagem & $\begin{array}{l}\text { Econômica } \\
\text { Ambiental } \\
\text { Social }\end{array}$ \\
\hline 5 & Parcerias & $\begin{array}{l}\text { a) Efetividade da rede de apoio } \\
\text { b) Efetividade de viabilização de recursos financeiros e } \\
\text { institucionais }\end{array}$ & $\begin{array}{c}\text { Social } \\
\text { Institucional } \\
\text { Econômica }\end{array}$ \\
\hline 6 & Condições de trabalho & Saúde e segurança no ambiente de trabalho & $\begin{array}{c}\text { Social } \\
\text { Saúde do trabalhador }\end{array}$ \\
\hline
\end{tabular}




\section{Continuação- Indicadores de sustentabilidade da coleta seletiva}

\begin{tabular}{|c|c|c|c|}
\hline & Indicadores & Processo & Dimensões da \\
\hline 7 & $\begin{array}{l}\text { Custo da seletiva/ } \\
\text { coleta domiciliar }+ \\
\text { aterramento }\end{array}$ & $\begin{array}{l}\text { a) Eficiência econômica no gerenciamento } \\
\text { b) Relação custo - benefício entre coleta seletiva e } \\
\text { aterramento } \\
\text { c) Ampliação do gasto com a coleta seletiva e redução } \\
\text { do gasto com coleta domiciliar e aterramento }\end{array}$ & $\begin{array}{l}\text { Ambiental } \\
\text { Social } \\
\text { Econômica }\end{array}$ \\
\hline 8 & Instrumentos legais & $\begin{array}{l}\text { a) Regularidade institucional } \\
\text { b) Inclusão social } \\
\text { c) Reconhecimento da prestação de serviço pelas } \\
\text { organizações de catadores }\end{array}$ & $\begin{array}{l}\text { Institucional } \\
\text { Social } \\
\text { Econômica }\end{array}$ \\
\hline 9 & $\begin{array}{l}\text { Custo do serviço/ } \\
\text { quantidade seletiva }\end{array}$ & Monitoramento do custo per capita da coleta seletiva & Econômica \\
\hline 10 & Educação /divulgação & $\begin{array}{l}\text { Sensibilização para a redução na fonte, reutilização, } \\
\text { reciclagem e consumo consciente }\end{array}$ & $\begin{array}{l}\text { Ambiental } \\
\text { Social } \\
\text { Institucional }\end{array}$ \\
\hline 11 & $\begin{array}{l}\text { Custo da coleta/ } \\
\text { manejo de RS }\end{array}$ & $\begin{array}{l}\text { Ampliação do gasto com a coleta seletiva e redução do } \\
\text { gasto com coleta domiciliar e aterramento }\end{array}$ & $\begin{array}{l}\text { Econômica } \\
\text { Ambiental }\end{array}$ \\
\hline 12 & $\begin{array}{l}\text { Inclusão de catadores } \\
\text { avulsos }\end{array}$ & Sustentabilidade Social, Inclusão social & $\begin{array}{l}\text { Social } \\
\text { Ambiental }\end{array}$ \\
\hline 13 & Autofinanciamento & Sustentabilidade economica da coleta seletiva & $\begin{array}{l}\text { Econômica } \\
\text { Institucional }\end{array}$ \\
\hline 14 & Gestão compartilhada & $\begin{array}{l}\text { a) Existência de mecanismos de compartilhamento da } \\
\text { gestão com a sociedade } \\
\text { b) controle social } \\
\text { c) transparência }\end{array}$ & $\begin{array}{l}\text { Social } \\
\text { Institucional }\end{array}$ \\
\hline
\end{tabular}


Quadro 10 - Indicadores de organizações de catadores, processos e dimensões da sustentabilidade abrangidas.

\begin{tabular}{|c|c|c|c|}
\hline \multicolumn{4}{|c|}{ Indicadores das organizações de catadores } \\
\hline & Indicadores & Processo & $\begin{array}{l}\text { Dimensões da } \\
\text { Sustentabilidade }\end{array}$ \\
\hline 1 & Renda média & $\begin{array}{l}\text { Melhorias: econômica, de condições de } \\
\text { vida e saúde e auto-estima. }\end{array}$ & $\begin{array}{l}\text { Econômica } \\
\text { Social }\end{array}$ \\
\hline 2 & $\begin{array}{l}\text { Atendimento aos requisitos de } \\
\text { segurança e saúde do ambiente de } \\
\text { trabalho }\end{array}$ & $\begin{array}{l}\text { Melhoria de condições de segurança e } \\
\text { saúde no ambiente de trabalho }\end{array}$ & $\begin{array}{l}\text { Social } \\
\text { Ambiental }\end{array}$ \\
\hline 3 & $\begin{array}{l}\text { Uso de equipamentos de proteção } \\
\text { individual }\end{array}$ & $\begin{array}{l}\text { Redução de riscos e acidentes de } \\
\text { trabalho }\end{array}$ & $\begin{array}{l}\text { Social } \\
\text { Saúde }\end{array}$ \\
\hline 4 & Participação dos membros em reuniões & $\begin{array}{l}\text { a) Efetividade da gestão cooperativa } \\
\text { b) Autogestão }\end{array}$ & $\begin{array}{l}\text { Institucional } \\
\text { Social }\end{array}$ \\
\hline 5 & Membros capacitados & $\begin{array}{l}\text { a) Eficiência do trabalho } \\
\text { b) Melhoria pessoal }\end{array}$ & $\begin{array}{c}\text { Social } \\
\text { Institucional }\end{array}$ \\
\hline 6 & Eficiência da produtividade/catador & Eficiência do trabalho & Econômica \\
\hline 7 & $\begin{array}{l}\text { Atendimento aos requisitos de } \\
\text { regularização }\end{array}$ & Regularidade institucional & $\begin{array}{l}\text { Institucional } \\
\text { Econômica }\end{array}$ \\
\hline 8 & Atendimento aos requisitos de saúde & $\begin{array}{l}\text { Melhoria de condições de saúde do } \\
\text { trabalhador }\end{array}$ & $\begin{array}{l}\text { Social } \\
\text { Saúde }\end{array}$ \\
\hline 9 & $\begin{array}{l}\text { Instrumentos legais na relação com a } \\
\text { prefeitura }\end{array}$ & $\begin{array}{l}\text { a) Qualificação da prestação de serviço } \\
\text { b) Melhoria da renda das organizações }\end{array}$ & $\begin{array}{l}\text { Institucional } \\
\text { Econômico }\end{array}$ \\
\hline 10 & $\begin{array}{l}\text { Atendimento aos requisitos de } \\
\text { autogestão }\end{array}$ & $\begin{array}{l}\text { a) Efetividade da gestão cooperativa } \\
\text { b) Capacidade organizacional }\end{array}$ & $\begin{array}{l}\text { Institucional } \\
\text { Social }\end{array}$ \\
\hline 11 & Horas trabalhadas & Condições de trabalho & $\begin{array}{l}\text { Social, Institucional } \\
\text { Saúde do trabalhador }\end{array}$ \\
\hline
\end{tabular}




\begin{tabular}{|c|c|c|c|}
\hline \multicolumn{4}{|c|}{ Continuação - Indicadores das organizações de Catadores } \\
\hline & Indicadores & Processo & $\begin{array}{l}\text { Dimensões da } \\
\text { Sustentabilidade }\end{array}$ \\
\hline 12 & Rotatividade dos membros & $\begin{array}{l}\text { Capacidade institucional de manter os } \\
\text { membros }\end{array}$ & $\begin{array}{c}\text { Social } \\
\text { Institucional }\end{array}$ \\
\hline 13 & Benefícios & $\begin{array}{l}\text { a) Capacidade institucional } \\
\text { b) Benefícios sociais, coesão e capital } \\
\text { social }\end{array}$ & $\begin{array}{c}\text { Social } \\
\text { Institucional }\end{array}$ \\
\hline 14 & Equipamentos e veículos & $\begin{array}{l}\text { a) Capacidade produtiva } \\
\text { b) Autonomia }\end{array}$ & $\begin{array}{l}\text { Econômica } \\
\text { Institucional }\end{array}$ \\
\hline 15 & Relação de ganhos entre gêneros & Equidade de gênero & $\begin{array}{c}\text { Social } \\
\text { Econômica }\end{array}$ \\
\hline 16. & Qualidade das parcerias & Tipo de aporte dado pela parceria & $\begin{array}{l}\text { Institucional } \\
\text { Social } \\
\text { Econômica }\end{array}$ \\
\hline 17 & Diversificação das atividades e serviços & $\begin{array}{l}\text { a) Capacidade organizacional } \\
\text { b) Ampliação da autonomia }\end{array}$ & $\begin{array}{l}\text { Econômica } \\
\text { Institucional }\end{array}$ \\
\hline 18 & Diversificação das parcerias & $\begin{array}{l}\text { a) Capacidade de articulação } \\
\text { b) Efetividade de rede de apoio } \\
\text { c) Acúmulo de Capital social } \\
\text { d) Capacidade de viabilização de recursos } \\
\text { financeiros e institucionais }\end{array}$ & $\begin{array}{l}\text { Social } \\
\text { Institucional } \\
\text { Econômica }\end{array}$ \\
\hline
\end{tabular}


Apresentam-se os indicadores, índices, fórmulas de cálculo e respectivas tendências à sustentabilidade da coleta seletiva, e das organizações de catadores segundo a avaliação dos especialistas, na ordem de importância a eles atribuída, no Apendice $O$.

Verificou-se que ao incluir na avaliação a forma de cálculo, que não foi apresentada na primeira rodada houve alteração significativa nas avaliações de alguns dos indicadores na $2^{\mathrm{a}}$ rodada.

O Indicador de Rotatividade ampliou a avaliação de muito alta e alta (notas $8,9,10$ ) de $39,4 \%$ para $65 \%$. O Ind. de Capacitação caiu de $91,5 \%$ para $80,9 \%$, o Ind. de Participação de $92,8 \%$ para $83,7 \%$, o Ind. de Equipamentos e veículos, de $70,9 \%$ para $57,5 \%$ e o Ind. de Beneficios de $74,3 \%$ para $62,5 \%$.

\subsubsection{A visão dos diversos atores em oficinas regionais}

Durante a aplicação da primeira rodada da técnica Delphi com especialistas foram realizadas quatro oficinas regionais: em São Paulo, Belo Horizonte, Rio de Janeiro e Recife. A finalidade destas oficinas foi de verificar a aceitação da metodologia de construção dos indicadores e a proposta de matrizes de sustentabilidade além de colher subsídios para a elaboração do grupo de indicadores da $2^{\text {a }}$ rodada.

A oficina de São Paulo foi realizada, em 2007, na sede da ABES-SP e contou com 12 participantes: membros da coordenação executiva do Fórum Lixo e Cidadania do Estado de São Paulo, representantes da Câmara Técnica de Saneamento da ABES-SP, técnicos da Prefeitura de São Paulo, docente da Universidade Estadual de Campinas (UNICAMP), técnicas do Instituto GEAÉtica e Meio Ambiente, e de organizações não governamentais, técnicos: da Secretaria de Estado de Meio Ambiente de São Paulo e da Caixa Econômica Federal. 
A oficina de Minas Gerais também em 2007 foi realizada no CETEC e contou com 17 participantes: representantes do CETEC, do Fórum Estadual Lixo e Cidadania de Minas Gerais, do INSEA, representante da rede de cooperativas de catadores - CATAUNIDOS, docentes da Universidade Federal de Minas Gerais/ DESA, técnicos da Prefeitura de Belo Horizonte e da SLU, e do Instituto Sustentar.

A oficina da cidade do Rio de Janeiro ocorreu no ano de 2008, na Universidade Estadual do Rio de Janeiro (UER) e no âmbito do evento "Rumos da Coleta Seletiva: boas práticas e indicadores de sustentabilidade. Contou com 66 participantes: acadêmicos, consultores, catadores, técnicos municipais, do governo estadual, ministérios e do setor privado.

A quarta oficina realizada na cidade de Recife, PE, em 2008, na sede do Conselho Regional de Engenharia - CREA Recife e contou com 35 participantes: membros do Fórum Lixo e Cidadania do Estado de Pernambuco, membros da Secretaria de Estado de Meio Ambiente de Pernambuco, representantes de organizações de catadores, Pró Recife, COOMSERE, Cooptrês, COOMSERE, Associação Arcoverde, membros da Prefeitura de Olinda membros de organizações não governamentais- ASPAN/PE, INCUBACOOP, membros da Associação Brasileira de Engenharia Sanitária, representantes da Empresa de Limpeza Urbana de Recife (EMLURB) e acadêmicos.

As contribuições dos participantes às quatro oficinas estão apresentadas no Quadro 11. Os itens que foram incorporados em alguma das etapas da pesquisa estão assinalados. 
Quadro 11 - Resultados de oficinas regionais, em São Paulo, Belo Horizonte Rio de Janeiro e Recife, 2007 e 2008.

\section{Oficinas regionais}

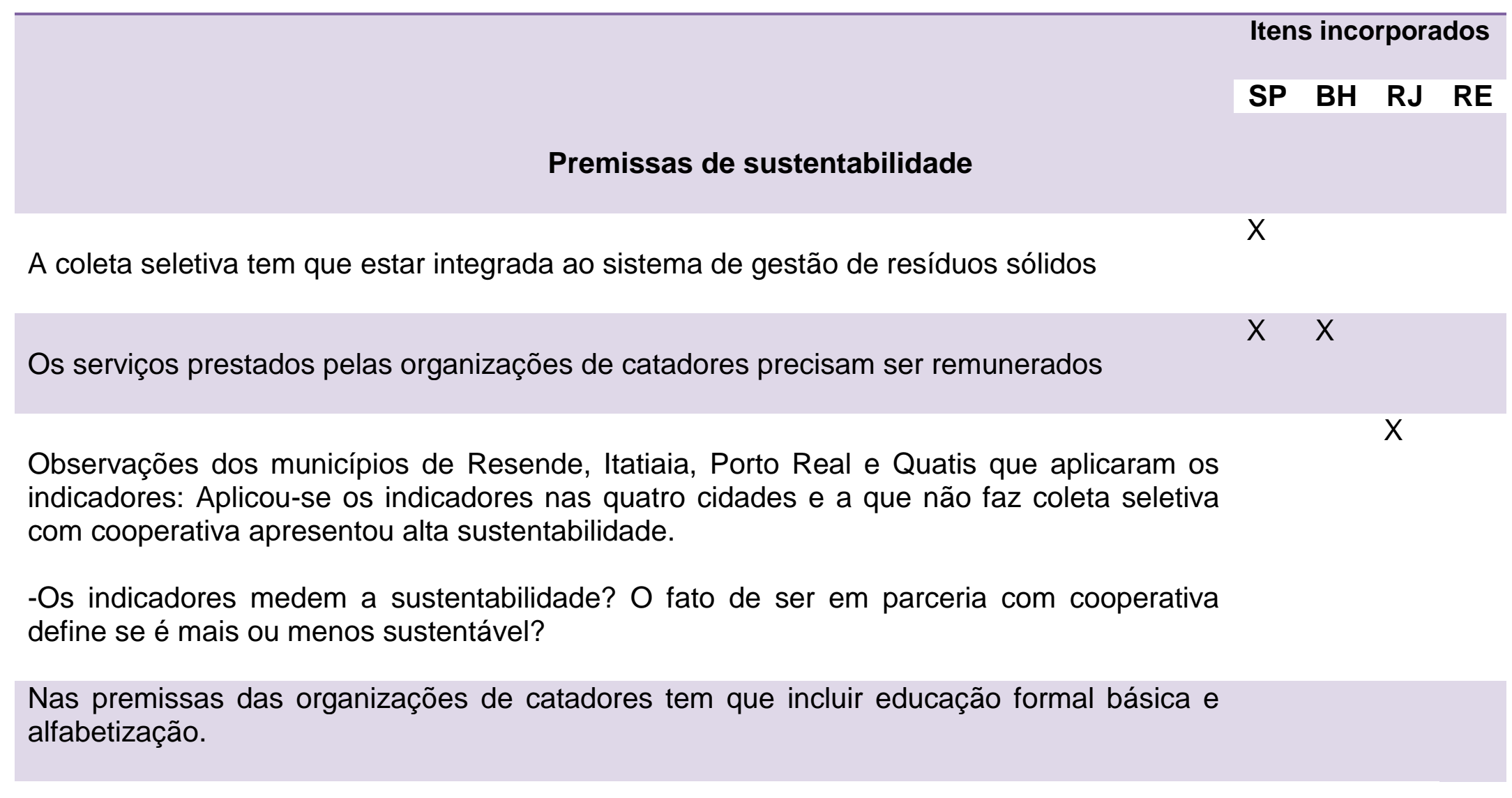




\section{Continuação: Oficinas regionais - Definições de sustentabilidade}

\section{Itens incorporados}

SP BH RJ RE

Por que resultados ambientais e sociais crescentes?

No conceito de sustentabilidade das organizações incluir: condições de saúde e segurança $\quad X \quad X \quad X \quad X$ do trabalho.

$\mathrm{Na}$ definição de sustentabilidade das organizações incluir: condições adequadas de educação, saúde e segurança do trabalho.

\section{Indicadores de coleta seletiva}

Ind.1 Sustentabilidade econômica

Ind.2

Marco legal

\section{Ind.3}

Parcerias
A existência de taxa não é um bom indicador, precisa saber se é aplicada no sistema ${ }^{41}$.

Incluir contrato como tendência à sustentabilidade $=(+)$.

a) Como fica se já teve parceria e não tem no momento.

b) Incluir temporalidade, tipo de parceria, qualificação, se é contínua ou não, freqüência, pesos diferenciados.

c) Precisa qualificar as parcerias (tipo, capacitação, equipamento, $\mathrm{x} \quad \mathrm{x} \quad \mathrm{x} \quad \mathrm{x}$ apoio técnico, recursos, compra de material, etc.)

\footnotetext{
${ }^{41}$ Comentário de participante: "no Nordeste as prefeituras não cobram nem no IPTU. A questão é se tem orçamento próprio ou não e não se cobra taxa. O programa de coleta seletiva de Recife tem um custo alto e resultados pequenos. Em Recife os catadores autônomos coletam 130 toneladas dia e o programa da prefeitura 3 toneladas dia".
} 


\section{Continuação: Oficinas regionais - Indicadores de coleta seletiva}

\begin{tabular}{|c|c|c|c|c|c|}
\hline \multirow[b]{3}{*}{$\begin{array}{l}\text { Ind.4 } \\
\text { Cobertura }\end{array}$} & & \multicolumn{4}{|c|}{ Itens incorporados } \\
\hline & & SP & $\mathrm{BH}$ & RJ & RE \\
\hline & $\begin{array}{l}\text { a) Georreferenciar cobertura, base do IBGE unidade censitária. } \\
\text { b) Criar um índice incluindo tamanho da população e tempo de } \\
\text { coleta. Por exemplo: pode cobrir } 100 \% \text { de uma cidade pequena e } \\
30 \% \text { de uma grande. } \\
\text { c) Cobertura da coleta- pesa menos que outros itens. Questão de } \\
\text { universalização X qualidade - dar peso } 1 / 2 \text { para a cobertura. } \\
\text { d) A cobertura deveria ser medida ao longo do tempo e de acordo } \\
\text { com o porte das cidades. } \\
\text { e) A medida deveria ser em número de casas atendidas e não por } \\
\text { toneladas coletadas. } \\
\text { f) Tem que considerar cobertura da coleta e participação da } \\
\text { população no indicador. }\end{array}$ & & & & \\
\hline $\begin{array}{l}\text { Ind.5 } \\
\text { TRMR }\end{array}$ & $\begin{array}{l}\text { a)Devido à comercialização e estocagem calcular uma média } \\
\text { anual seria mais adequado. } \\
\text { b) Mudar percentuais da tendência à sustentabilidade alta, acima } \\
\text { de } 10 \% \% \text {, média entre } 5,1 \text { e } 9,9 \% \text {, baixa até } 5 \% \text {. } \\
\text { c) Aumentar a tendência à sustentabilidade alta, pois } 10 \% \text { para } \\
\text { municípios pequenos é baixo e para municípios grandes é alto. O } \\
\text { SNIS divide os municípios por categorias de população. }\end{array}$ & & $X$ & & $X$ \\
\hline $\begin{array}{l}\text { Ind.6 } \\
\text { Taxa de rejeito }\end{array}$ & $\begin{array}{l}\text { a) Devido à comercialização e estocagem dos recicláveis, calcular } \\
\text { uma média anual. } \\
\text { b) A interceptação de catadores avulsos pode aumentar o índice } \\
\text { de rejeito, portanto, não é um bom indicador para participação. }\end{array}$ & & & & \\
\hline
\end{tabular}




\section{Continuação: Oficinas regionais - Indicadores de organizações de catadores}

\begin{tabular}{|c|c|c|c|c|c|}
\hline \multirow[b]{3}{*}{$\begin{array}{l}\text { Ind.1 } \\
\text { Regularização }\end{array}$} & \multirow[b]{3}{*}{$\begin{array}{l}\text { Incluir tendência à sustentabilidade de organizações em processo de } \\
\text { regularização }=(+/-)\end{array}$} & \multicolumn{4}{|c|}{ Itens incorporados } \\
\hline & & SP & $\mathrm{BH}$ & $\mathbf{R J}$ & RE \\
\hline & & & & & \\
\hline $\begin{array}{l}\text { Ind.2 } \\
\text { Instrumento } \\
\text { legal }\end{array}$ & $\begin{array}{l}\text { a)Tendência cooperativas com contrato ou convênio remunerado = +. } \\
\text { b) Fica uma dúvida se associação com convênio é }(+) \text { ou }(+/-) \\
\text { (Caso da Asmare em } \mathrm{BH})\end{array}$ & & & & \\
\hline Ind.3 & a) Mudar a forma de cálculo de rotatividade & $X$ & & & \\
\hline Rotatividade & b) Calcular média dos últimos 6 meses e não anual. & & & & $X$ \\
\hline $\begin{array}{l}\text { Ind.4 } \\
\text { Capacitação } \\
\text { dos membros }\end{array}$ & $\begin{array}{l}\text { Alterar tendência à sustentabilidade - capacitação permanente }=(+) \text {, } \\
\text { capacitação pontual }=(+/-) \text { e não capacitada }=(-)\end{array}$ & & & & \\
\hline $\begin{array}{l}\text { Ind.5 } \\
\text { Renda média }\end{array}$ & $\begin{array}{l}\text { a)Trocar renda mensal por hora trabalhada com base no salário mínimo } \\
\text { b) A renda ser medida em horas trabalhadas e não renda mensal }\end{array}$ & $X$ & & & \\
\hline $\begin{array}{l}\text { Ind.6 } \\
\text { Participação }\end{array}$ & $\begin{array}{l}\text { Alterar tendência à sustentabilidade-menos de } 50 \%=(-) \text {, entre } 50 \% \text { e } 75 \% \\
=(+/-) \text { e acima de } 75 \%=(+) .\end{array}$ & & & & $X$ \\
\hline $\begin{array}{l}\text { Ind.7 } \\
\text { Condições da } \\
\text { Instalação }\end{array}$ & $\begin{array}{l}\text { a) Alterar tendência à sustentabilidade Próprio }=(+) \text {, concessão= }(+/-) \text {, e } \\
\text { emprestado, comodato, alugado ou cedido= }(-) \text {. } \\
\text { b) Não representa condição da instalação, precisa ser alterado. } \\
\text { c) Condição da instalação deve considerar a logística do funcionamento da } \\
\text { cooperativa, como entra e como sai o resíduo - organização. } \\
\text { c) As áreas e centrais devem ser cedidas pelas prefeituras? Então a } \\
\text { gradação deveria ser mais para as cedidas. } \\
\text { d) Cessão de área tem mais vantagens do que alugada e a gradação } \\
\text { deveria ter gradação mais } \\
\text { e) Alterar tendência à sustentabilidade cedida legalmente por } X \text { anos }=(+)\end{array}$ & $X$ & $X$ & $X$ & $X$ \\
\hline
\end{tabular}




\section{Continuação: Oficinas regionais - Indicadores de organizações de catadores}

\begin{tabular}{|c|c|c|c|c|}
\hline & & Iten & incorpor & dos \\
\hline & & SP & BH $\mathbf{R J}$ & RE \\
\hline $\begin{array}{l}\text { Ind.8 } \\
\text { Veículos/ } \\
\text { equipamentos }\end{array}$ & $\begin{array}{l}\text { - Separar equipamentos de veículos. } \\
\text { - Alterar tendência à sustentabilidade alugado=(+/-). }\end{array}$ & & & \\
\hline $\begin{array}{l}\text { Ind.9 } \\
\text { Horas } \\
\text { trabalhadas }\end{array}$ & $\begin{array}{l}\text { - Nas horas trabalhadas não está considerada a produtividade. } \\
\text { - Alterar tendência à sustentabilidade }- \text { entre } 6 \text { e } 8 \text { horas }=(+) \text { entre } 4 \text { e } 6 \\
\text { horas }==(+/-) \text { e até } 4 \text { ou + de } 8 \text { horas }=(-) . \\
\text {-Rever tendência à sustentabilidade até } 8 \text { horas }=(+) .\end{array}$ & & $x$ & $x$ \\
\hline $\begin{array}{l}\text { Ind.10 } \\
\text { Benefícios }\end{array}$ & $\begin{array}{l}\text { Usar os Fundos legais existentes: Fundo de Reserva, INSS, e outros, } \\
\text { gratificação Natalina, educacional, creche. Tem que verificar para as } \\
\text { associações como fica. }\end{array}$ & & & \\
\hline $\begin{array}{l}\text { Ind.12 } \\
\text { Parcerias }\end{array}$ & $\begin{array}{l}\text { - Qual é a contribuição das parcerias no montante da renda da } \\
\text { organização. } \\
\text { - Construir subcategorias de parcerias. } \\
\text { - Como qualificar melhor as parcerias? } \\
\text { - Precisa tipificar as parcerias }(+)=\text { capacitação, equipamentos, espaço, } \\
\text { pessoal de apoio }(+/-)=\text { uma destas, e (-) nenhuma. }\end{array}$ & & & \\
\hline
\end{tabular}




\section{Continuação - Oficinas regionais - Propostas de novos indicadores de coleta seletiva}

Itens incorporados

SP BH RJ RE

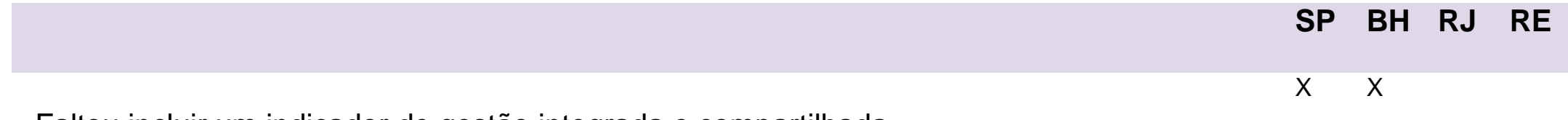

-Faltou incluir um indicador de gestão integrada e compartilhada.

-Indicador de gestão compartilhada? quesito participação. Se há instâncias de gestão integrada (ex. Santo André).

Incluir minimização, programa de educação ambiental permanente.

$x$

Falta um indicador de educação ambiental.

Incluir instrumentos de política pública e controle social.

Construir índice de parcerias.

$\mathrm{X} \quad \mathrm{X}$

Construir indicador de adesão é muito importante.

Construir indicador de adesão junto com o de cobertura.

Incluir indicadores de inclusão e controle social.

Incluir indicador de resultados econômicos.

Inserir indicador de eficiência social, mais renda para mais pessoas. 


\section{Continuação: Oficinas regionais- Propostas de novos indicadores de organizações de catadores}

\begin{tabular}{|c|c|c|c|c|}
\hline & Itens & inco & porá & dos \\
\hline & SP & $\mathrm{BH}$ & RJ & RE \\
\hline $\begin{array}{l}\text { Construir indicador de educação ambiental. } \\
\text { Proposta de tendência à sustentabilidade: permanente }=(+) \text {, esporádico }=(+/-) \text {, não tem=(-). }\end{array}$ & $\mathrm{X}$ & & & \\
\hline Remuneração das organizações de catadores & $\mathrm{X}$ & & & \\
\hline Construir índice de parcerias. & $\mathrm{X}$ & $\mathrm{X}$ & $\mathrm{X}$ & $\mathrm{X}$ \\
\hline $\begin{array}{l}\text { Fazer um índice de comercialização - número de itens, quantidade, freqüência, forma de } \\
\text { venda, periodicidade, beneficiamento capacidade de comercialização. }\end{array}$ & & & & \\
\hline Inserir Rede de apoio - comercialização conjunta & $\mathrm{X}$ & $\mathrm{X}$ & $\mathrm{X}$ & $\mathrm{X}$ \\
\hline Incluir a TRMR em relação aos bairros & & & $\mathrm{X}$ & \\
\hline Incluir a TRMR, pois também serve às organizações & & $\mathrm{X}$ & & \\
\hline Incluir a TR, pois também serve às organizações & & $\mathrm{X}$ & & \\
\hline $\begin{array}{l}\text { - Índice de produtividade deve ser composto por vários indicadores. } \\
\text { - Produtividade econômica e social } \\
\text { - Incluir indicador de produtividade - cálculo pela produtividade geral dividida pelo n de } \\
\text { membros, ou seja, produtividade média. } \\
\text { - Estudar indicador de produtividade, ganhos por hora trabalhada }\end{array}$ & & & & $x$ \\
\hline Incluir um indicador de saúde & & $\mathrm{X}$ & $\mathrm{X}$ & \\
\hline $\begin{array}{l}\text { Incluir indicadores de condições e trabalho - carga de trabalho diária, esforço físico } \\
\text { excessivo, sinais, sintomas, doenças adquiridas no trabalho, fatores de risco físico, químico, } \\
\text { biológico, ergonômico e acidentário. }\end{array}$ & & $\mathrm{X}$ & & \\
\hline
\end{tabular}




\section{Continuação: Oficinas regionais - Comentários}

\begin{tabular}{|c|c|c|c|c|}
\hline & Itens & inco & rpore & dos \\
\hline & SP & BH & RJ & RE \\
\hline Incentivo à autonomia das organizações de catadores & & & & \\
\hline Diferenciar autonomia de gestão e econômica- financeira & & & & \\
\hline Universalização, mas aumento progressivo da cobertura & & & & \\
\hline $\begin{array}{l}\text { Sustentabilidade das organizações coleta, separação, beneficiamento, comercialização e } \\
\text { capacitação continuada. }\end{array}$ & & & & \\
\hline $\begin{array}{l}\text { Indicadores } 5 \text { e } 6 \\
\text { Quando houver mais de uma organização trabalhar com a somatória }\end{array}$ & & & & \\
\hline $\begin{array}{l}\text { É preciso substituir a nomenclatura de coleta regular por coleta domiciliar, pois a regular } \\
\text { abrange outros serviços. }\end{array}$ & & $X$ & & $\mathrm{X}$ \\
\hline $\begin{array}{l}\text { Momento político é importante para as organizações. Não dá para trabalhar } \\
\text { sustentabilidade independente das políticas públicas e da participação, o cidadão faz a } \\
\text { segregação, é o próprio cliente faz o serviço. }\end{array}$ & & & & \\
\hline
\end{tabular}

Medir a quantidade desviada do aterro e não do que está chegando para a triagem para medir a eficiência da educação ambiental.

O novo código civil vai dificultar para a regularização para as associações, BNDES e Governo Federal só financia cooperativas. 
A maioria das contribuições dos participantes das oficinas foi convergente com as avaliações de especialistas. Estas apoiaram a análise qualitativa e a seleção dos indicadores da segunda rodada e ajudaram a calibrar as tendências à sustentabilidade de alguns indicadores.

Observaram-se nas oficinas regionais avaliações diferenciadas, referentes aos indicadores e às tendências à sustentabilidade.

Em relação à coleta seletiva, um dos questionamentos foi em relação à aplicação das mesmas tendências à sustentabilidade a municípios de diferentes portes a exemplo dos indicadores TRMR (Ind. 5) e Cobertura (Ind. 4), para os quais os participantes achavam necessário haver faixas diferenciadas, tal como ocorre nos levantamentos do SNIS. O argumento era que a alta tendência à sustentabilidade era mais fácil de ser atingida em cidades de menor porte.

Nesse caso não foram incorporadas as sugestões, pois se entende que na perspectiva da sustentabilidade, se uma cidade pequena oferece mais vantagens para a coleta seletiva isto é um ponto positivo ao seu favor, assim como cidades médias e grandes podem ter outros, por exemplo, maior arrecadação, ou condições técnicas, etc.

Os municípios de Resende, Itatiaia, Porto Real e Quatis, todas do Rio de Janeiro que aplicaram os indicadores da pesquisa COSELIX levantaram questionamentos importantes. Foram aplicados os indicadores nas quatro cidades e a única que não opera coleta seletiva com cooperativa de catadores apresentou alta sustentabilidade. A partir desta constatação questionaram se os indicadores medem a sustentabilidade, e se o fato da coleta seletiva ser operada em parceria com cooperativa pode definir se é mais ou menos sustentável.

Esta é uma questão central na pesquisa, pois considerada a sustentabilidade não apenas na perspectiva econômica e ambiental, mas de inclusão social de catadores (BESEN, 2006; DEMAJOROVIC et al., 2006; GÜNTHER e GRIMBERG, 2006; MEDINA, 2007; DIAS, 2009; BAEDER, 2010) 
entende-se que os indicadores devem valorizar este aspecto. Uma das alternativas foi apresentada na segunda rodada do Delphi por vários especialistas com a proposta de inclusão de organizações de catadores no indicador de parcerias, ou seja, um município que não tenha esta modalidade de parceria apresenta um desempenho menos sustentável.

Em relação às organizações, o indicador Condição da Instalação (Ind.7) foi criticado nas oficinas assim como pelos especialistas, desse modo foi excluído da $2^{\mathrm{a}}$ rodada. Houve consenso de que o nome do indicador estava equivocado e não refletia o que se propunha a medir, que era a situação legal da instalação. Não houve consenso quanto às tendências à sustentabilidade entre centrais alugadas, cedidas pela prefeitura ou próprias. Foi proposta a criação de um indicador para avaliar as condições de trabalho das instalações.

Também se propôs a alteração das tendências à sustentabilidade do indicador Instrumento Legal na relação com as prefeituras (Ind. 2), uma vez que estas foram formuladas nos anos de 2004 e 2005, quando não existia legislação especifica que permitisse esta relação, e raros municípios tentavam formas alternativas, como é o caso de Diadema. No momento a sustentabilidade econômica das organizações de catadores esta muito associada ao pagamento pelos serviços prestados (RIBEIRO et al., 2009; IPEA, 2010).

\subsubsection{A visão de atores em oficinas específicas}

Com o objetivo de ampliar as visões sobre as definições de indicadores de sustentabilidade avaliados na $2^{-}$rodada de aplicação da técnica Delphi foram realizadas 3 oficinas específicas: uma com organizações de catadores de várias regiões e cidades do país, uma com técnicos municipais da prefeitura de Belo Horizonte e da Superintendência de Limpeza Urbana (SLU) e uma com uma organização não governamental com atuação na assessoria e apoio aos 
catadores em Minas Gerais e também com atuação nas políticas públicas INSEA.

A) A visão das organizações de catadores

A oficina com as organizações foi realizada em 23 de setembro de 2009, e integrada às atividades do 8 ํ Festival Lixo e Cidadania em Belo Horizonte.

Contou com 27 participantes representantes de organizações de catadores com atuação em 5 estados: Espírito Santo, Minas Gerais, Rio de Janeiro, Paraná e São Paulo. Dentre os participantes, 12 (44,4\%) eram representantes do Movimento Nacional dos Catadores dos estados de: Espírito Santo (2), Minas Gerais (3), Rio de Janeiro (3) e São Paulo (4). A duração da oficina foi de três horas.

As definições escolhidas para sustentabilidade da coleta seletiva e para organizações de catadores foram as de número 2, consideradas mais completas. Os catadores e consideraram importante a inclusão de três indicadores da coleta seletiva também para as organizações de catadores: 0 indicador de adesão da população (para a população atendida), o indicador da taxa de recuperação de materiais recicláveis e da taxa de rejeito.

O resultado da avaliação se encontra no Quadro 12. Os comentários e sugestões sobre os indicadores de sustentabilidade são apresentadas no APÊNDICE P.

Destaca-se um aspecto relevante que foi a reação positiva dos catadores na medida em que aumentava o seu entendimento com relação ao significado dos indicadores e as possibilidades de uso. Isto estimulou o envolvimento e a participação resultando em importantes reflexões e contribuições. 
Quadro 12 - Resultado da avaliação da oficina específica com organizações de catadores, Belo Horizonte, 2009.

\begin{tabular}{lccc}
\hline \multicolumn{4}{c}{ Indicadores de Sustentabilidade } \\
\hline & Aprovados & $\begin{array}{c}\text { Aprovados } \\
\text { com ressalva }\end{array}$ & Reprovados \\
Coleta seletiva & 6 & 3 & 1 \\
Organizações de catadores & 12 & 5 & 1 \\
\hline
\end{tabular}

Os dois indicadores reprovados foram:

a) Para a coleta seletiva, o indicador de educação ambiental, pois foi considerado que estava incluído no de adesão, ou seja, quanto maior adesão significa que a educação ambiental atingiu seu objetivo.

b) Para as organizações de catadores o indicador de ganhos entre gêneros, pois os participantes consideraram que uma organização de catadores já tem como pressuposto o ganho igualitário entre homens e mulheres, portanto era um indicador desnecessário. Em nenhuma das organizações que participaram do evento havia diferença de ganhos entre gêneros.

Com relação ao indicador TRMR, é importante destacar que embora o indicador tenha sido aprovado, os catadores apontaram a necessidade de estabelecer uma forma de cálculo que leve em conta o volume transportado e não apenas o peso. Eles entendem que o grande volume dos materiais recicláveis implica no aumento da quantidade de viagens e impacta a taxa de recuperação dos materiais recicláveis. 
Figura 11- Fotos da oficina com organizações de catadores, 2009
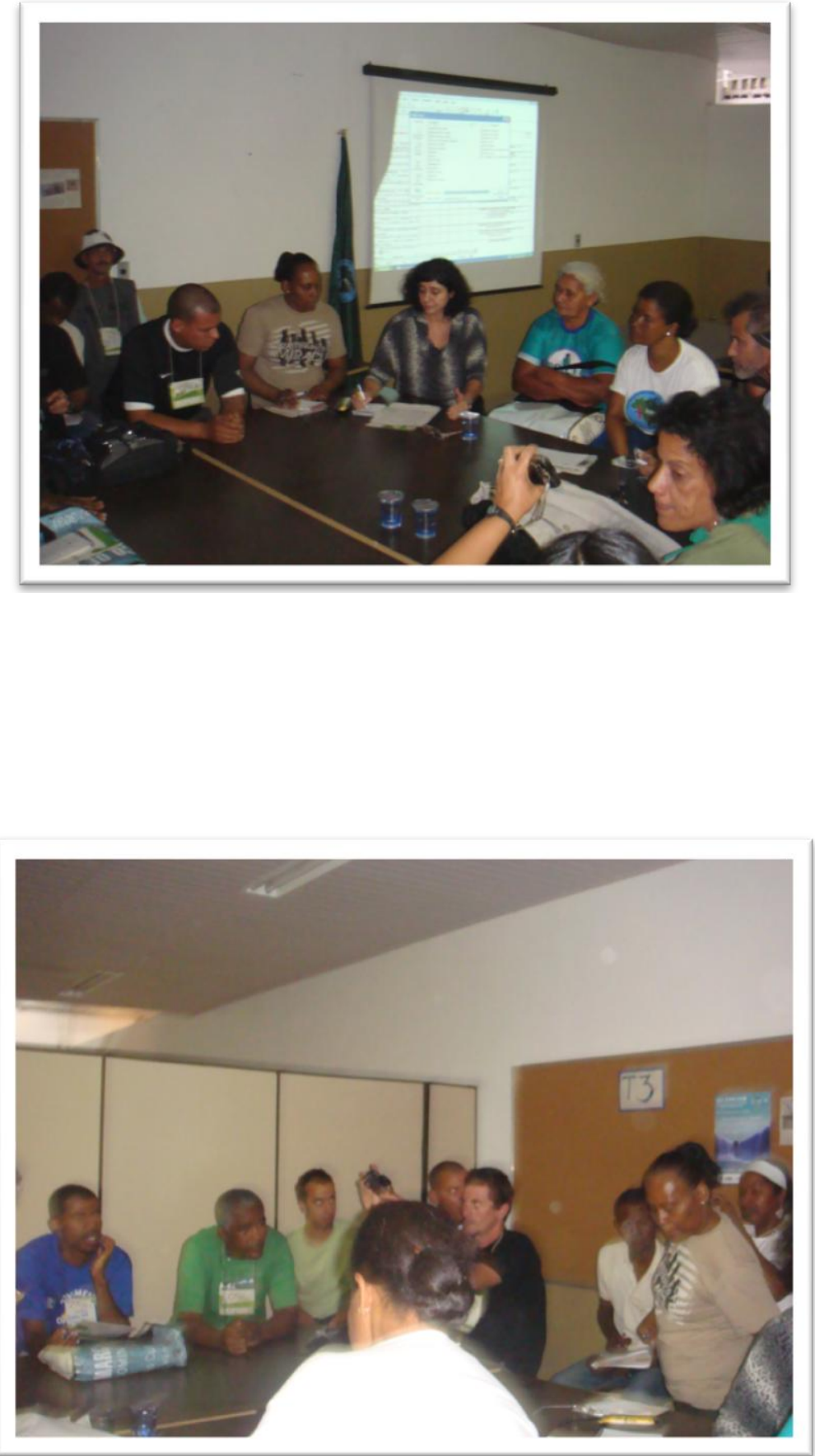
B) A visão dos técnicos municipais

A oficina com técnicos da SLU e da prefeitura de Belo Horizonte foi realizada no Auditório da SLU, em 2009. Contou com a participação de 28 técnicos.

A definição de sustentabilidade 2 da coleta seletiva foi aprovada com a complementação do conceito de eficiência enquanto um serviço de qualidade, com a melhor relação custo-benefício. Em relação à definição 2 de sustentabilidade de uma organização de catadores de materiais recicláveis, esta foi aprovada e os argumentos foram os mesmos.

Os resultados da avaliação se encontram no Quadro 13. Os comentários e sugestões são apresentados no APÊNDICE Q.

Quadro 13- Resultado da avaliação da oficina específica com técnicos da SLU, Belo Horizonte, 2009.

\section{Indicadores de Sustentabilidade}

\begin{tabular}{lccc}
\hline & Aprovados & $\begin{array}{c}\text { Aprovados } \\
\text { com ressalva }\end{array}$ & Reprovados \\
Coleta seletiva & 9 & 4 & 1 \\
$\begin{array}{l}\text { Organizações de } \\
\text { catadores }\end{array}$ & 15 & 3 & - \\
\hline
\end{tabular}

O único indicador reprovado foi o de educação ambiental, pois assim como na oficina com organizações de catadores foi considerado incluso no indicador de adesão e não houve concordância com sua forma de medição. 
Figura 12- Fotos da oficina com técnicos da prefeitura de Belo Horizonte, 2009.
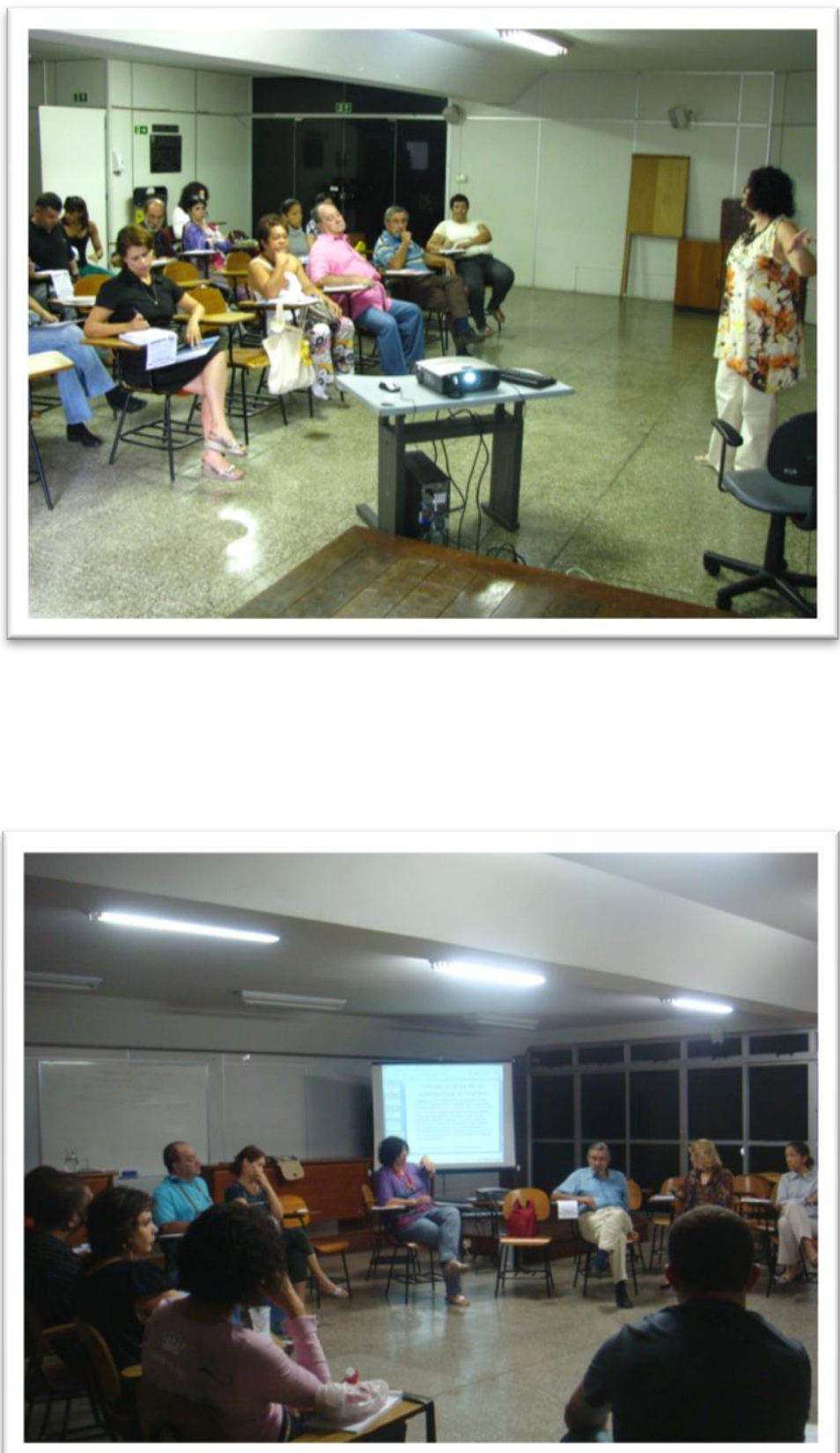
C) A visão da organização não governamental

A oficina com técnicos do INSEA foi realizada na PUC de Belo Horizonte, em 2009. Contou com a participação de 12 técnicos que atuam em diversos programas e projetos da organização.

Resultou da avaliação das definições de sustentabilidade que as de número 2 tanto da coleta seletiva quanto das organizações de catadores foram aprovadas. Em relação à primeira foi discutido se deveria ser inclusão social ou inclusão social de catadores e optou-se pela primeira.

Os resultados da avaliação dos indicadores encontram-se no Quadro 14. Os comentários e sugestões são apresentados no APÊNDICE R.

Quadro 14 - Resultado da avaliação da avaliação da oficina específica, com técnicos do INSEA, Belo Horizonte, 2010.

\begin{tabular}{lccc}
\hline \multicolumn{4}{c}{ Indicadores de Sustentabilidade } \\
\hline & Aprovados & $\begin{array}{c}\text { Aprovados } \\
\text { com ressalva }\end{array}$ & Reprovados \\
Coleta seletiva & 8 & 5 & 1 \\
Organizações de catadores & 6 & 10 & 2 \\
\hline
\end{tabular}

O indicador da coleta seletiva reprovado foi o Ind. 5- Gestão compartilhada, pois o grupo entendeu que não existe uma definição clara e se esta relacionada ao envolvimento dos catadores na co-gestão do programa ou ao envolvimento da sociedade. Dois indicadores das organizações de catadores foram reprovados: Ind. 14 - Horas trabalhadas, pois não houve concordância com a forma de cálculo e Ind. 15 - Ganhos entre gêneros, pois segundo a experiência dos participantes, assim como das dos de catadores isto não ocorre nas organizações cooperativas. 
Os técnicos do INSEA também consideraram importante a inclusão de três indicadores da coleta seletiva também para as organizações de catadores: o indicador de adesão da população (para a população atendida), o indicador da taxa de recuperação de materiais recicláveis e da taxa de rejeito.

Figura 13- Fotos da oficina com técnicos do INSEA, 2010.
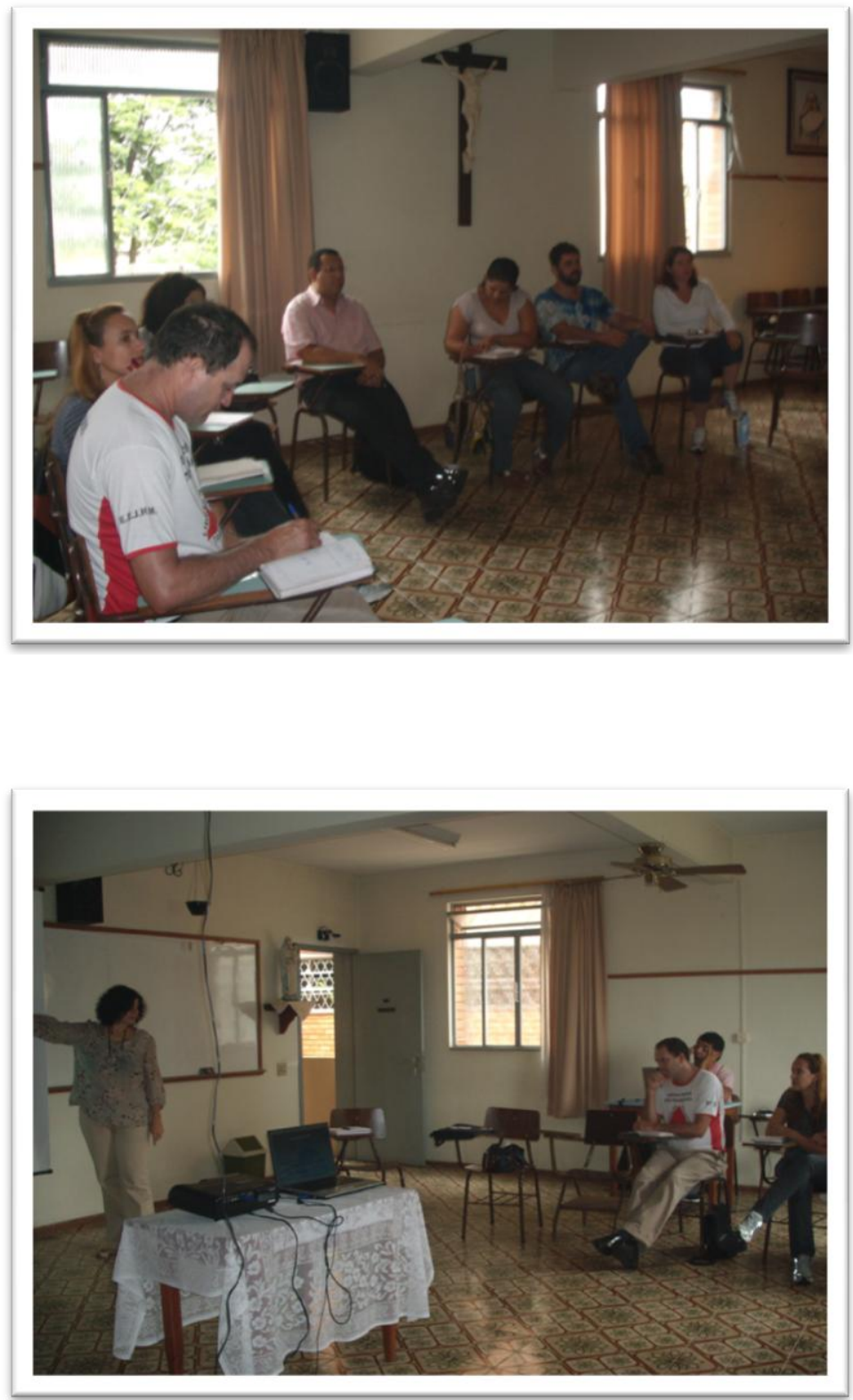
7.2.4 A busca de convergências nas diferentes visões

A pesquisa teve como objetivo avaliar e selecionar um conjunto de indicadores que melhor represente a sustentabilidade da coleta seletiva e de organizações de catadores. A base da pesquisa foi a aplicação da técnica Delphi com especialistas, a partir da qual resultou uma avaliação isenta e não direcionada pela pesquisadora ou por partes interessadas.

Entretanto, no decorrer da pesquisa e da oportunidade de ouvir diferentes pontos de vista optou-se por realizar avaliações por meio de oficinas específicas para verificar as convergências e divergências.

Considerando as diferenças metodológicas entre dois formatos desenvolvidos ao longo da pesquisa, o Quadro 15 apresenta resultados da avaliação de ambas definições de sustentabilidade (coleta seletiva e organizações de catadores), os indicadores/índices de coleta seletiva e de organizações de catadores obtidos nas diferentes consultas.

Quadro 15 - Avaliação das definições de sustentabilidade por especialistas, organizações de catadores, técnicos da SLU e técnicos do INSEA

\begin{tabular}{|c|c|c|c|c|c|}
\hline Definição & Especialistas & $\begin{array}{l}\text { Org. de } \\
\text { catadores }\end{array}$ & SLU & INSEA & Resultado \\
\hline $\begin{array}{l}\text { Coleta } \\
\text { seletiva }\end{array}$ & $\begin{array}{c}\text { A } \\
\text { definição } 2\end{array}$ & $\begin{array}{c}\text { A } \\
\text { definição } 2\end{array}$ & $\begin{array}{c}\text { AR } \\
\text { definição } 2\end{array}$ & $\begin{array}{c}\text { A } \\
\text { definição2 }\end{array}$ & $\begin{array}{c}\text { A } \\
\text { definição } 2\end{array}$ \\
\hline $\begin{array}{l}\text { Org. de } \\
\text { catadores }\end{array}$ & $\begin{array}{c}\text { A } \\
\text { definição } 2\end{array}$ & $\begin{array}{c}\text { A } \\
\text { definição } 2\end{array}$ & $\begin{array}{c}\text { AR } \\
\text { definição } 2\end{array}$ & $\begin{array}{c}\text { A } \\
\text { definição2 }\end{array}$ & $\begin{array}{c}\text { A } \\
\text { definição } 2\end{array}$ \\
\hline
\end{tabular}

Notas: A- aprovada AR - aprovada com ressalvas $\quad$ R- reprovada 
Os diversos grupos consultados aprovaram as duas definições de sustentabilidade (número 2) em relação à coleta seletiva e às organizações de catadores (mencionadas, na p.121).

Com relação à avaliação dos indicadores obteve-se que do total de 14 indicadores (Quadro 16), 7 foram aprovados pelos grupos nos quais foram avaliados (Inds. 1, 2, 7, 9, 11,12 e 13), e 5 com ressalvas (Inds., 3, 6, 8,10 e 14) descritas nos APENDICES P, Q, e R. Apenas 2 não foram aprovados (Inds. 4 e $5)$.

O indicador mais questionado pelos grupos foi o relativo ao tema de Educação e Divulgação (Ind.4). Apesar de ser considerado importante, não houve consenso sobre a forma de medir e definir as tendências à sustentabilidade. Os grupos entenderam que a adesão voluntária da população à coleta seletiva é um bom indicador para medir o resultado da educação ambiental.

O indicador de Gestão compartilhada (Ind. 5) foi aprovado com ressalvas de complementação de itens por dois grupos.

No caso do indicador de Inclusão de catadores avulsos (Ind. 6) as ressalvas foram no sentido de que se deve medir a inclusão a partir de metas estabelecidas pelo programa e não em relação ao total de catadores existentes no município, pois este último foi considerado inviável para municípios de médio e grande porte, nos quais o número de catadores é muito grande.

O indicador de Parcerias (Ind. 3) foi considerado importante por todos os grupos, no entanto todos consideram que se deve construir um índice de parcerias. 
Quadro 16- Avaliação de indicadores de sustentabilidade de coleta seletiva por organizações de catadores, técnicos da SLU e técnicos do INSEA.

\begin{tabular}{lcccc}
\hline \multicolumn{1}{c}{ Indicadores } & $\begin{array}{c}\text { Org. de } \\
\text { Catadores }\end{array}$ & SLU & INSEA & Resultado \\
\hline 1. Atendimento da população & $\mathrm{A}$ & $\mathrm{A}$ & $\mathrm{A}$ & $\mathrm{A}$ \\
2. Adesão da população & $\mathrm{A}$ & $\mathrm{A}$ & $\mathrm{A}$ & $\mathrm{A}$ \\
3. Parcerias & $\mathrm{AR}$ & $\mathrm{AR}$ & $\mathrm{AR}$ & $\mathrm{AR}$ \\
$\begin{array}{l}\text { 4. Educação e divulgação } \\
\text { 5. Gestão compartilhada }\end{array}$ & $\mathrm{R}$ & $\mathrm{R}$ & $\mathrm{AR}$ & $\mathrm{R}$ \\
$\begin{array}{l}\text { 6. Inclusão de catadores } \\
\text { avulsos }\end{array}$ & $\mathrm{A}$ & $\mathrm{AR}$ & $\mathrm{A}$ & $\mathrm{R}$ \\
$\begin{array}{l}\text { 7.Instrumentos legais na relação } \\
\text { com as org. }\end{array}$ & $\mathrm{A}$ & $\mathrm{A}$ & $\mathrm{AR}$ & $\mathrm{AR}$ \\
$\begin{array}{l}\text { 8. TRMR } \\
\text { 9. Taxa de rejeito }\end{array}$ & $\mathrm{AR}$ & $\mathrm{A}$ & $\mathrm{A}$ & $\mathrm{A}$ \\
10. Condições de trabalho & $\mathrm{A}$ & $\mathrm{A}$ & $\mathrm{A}$ & $\mathrm{A}$ \\
$\begin{array}{l}\text { 11. Autofinanciamento } \\
\text { 12. Custo da coleta seletiva/ }\end{array}$ & $\mathrm{A}$ & $\mathrm{AR}$ & $\mathrm{AR}$ & $\mathrm{AR}$ \\
manejo de RS & -- & $\mathrm{A}$ & $\mathrm{A}$ & $\mathrm{A}$ \\
13. Custo da coleta seletiva/ & -- & $\mathrm{A}$ & $\mathrm{A}$ & $\mathrm{A}$ \\
quantidade coleta seletiva & & $\mathrm{A}$ & $\mathrm{A}$ & $\mathrm{A}$ \\
14. Custo da coleta seletiva/ & -- & $\mathrm{A}$ & $\mathrm{AR}$ & $\mathrm{AR}$ \\
coleta domiciliar e aterramento & & & & \\
\hline
\end{tabular}

Notas: A- aprovado AR - aprovado com ressalvas R- reprovado

Destaca-se o indicador TRMR (Ind. 8) que foi aprovado pelos três grupos, mas teve uma ressalva do grupo dos catadores na sua fórmula de cálculo. Os catadores consideraram que aspectos relativos ao volume dos recicláveis afetam a sua coleta e deveriam ter sido considerados na fórmula de cálculo.

Quanto ao Custo da Coleta Seletiva/ coleta domiciliar e aterramento (Ind. 14) um dos grupos recomendou a troca do nome do indicador para coleta domiciliar de resíduos sólidos em substituição a coleta regular, e tratamento e disposição final no lugar de aterramento, o que foi incorporado.

Os Quadros 16 e 17 mostram que nas oficinas específicas a maioria dos indicadores da coleta seletiva e de organizações de catadores foram 
aprovados. Como se pode observar várias ressalvas de complementação foram propostas, o que enriquece o conjunto de temas apresentados. Este resultado é previsível num encontro desta natureza, pois muitas destas complementações vieram ao encontro da avaliação feita pelos especialistas, mostrando muita convergência nos conceitos estruturantes que se consolidaram a respeito da coleta seletiva e das organizações de catadores.

Quadro 17 - Avaliação de indicadores de sustentabilidade das organizações de catadores por especialistas, organizações de catadores, técnicos da SLU e técnicos do INSEA.

\begin{tabular}{lcccc}
\hline \multicolumn{1}{|c}{ Indicadores } & $\begin{array}{c}\text { Org.de } \\
\text { catadores }\end{array}$ & SLU & INSEA & Resultado \\
\hline 1. Regularização & $\mathrm{A}$ & $\mathrm{A}$ & $\mathrm{AR}$ & $\mathrm{A}$ \\
2. Instrumentos legais & $\mathrm{A}$ & $\mathrm{A}$ & $\mathrm{AR}$ & $\mathrm{A}$ \\
3. Parcerias - Qualidade & $\mathrm{AR}$ & $\mathrm{AR}$ & $\mathrm{AR}$ & $\mathrm{AR}$ \\
4. Parcerias- Diversificação & $\mathrm{A}$ & $\mathrm{AR}$ & $\mathrm{AR}$ & $\mathrm{AR}$ \\
5. Atividades e serviços & $\mathrm{A}$ & $\mathrm{A}$ & $\mathrm{AR}$ & $\mathrm{A}$ \\
6. Autogestão & $\mathrm{A}$ & $\mathrm{A}$ & $\mathrm{AR}$ & $\mathrm{A}$ \\
7. Participação em reuniões & $\mathrm{A}$ & $\mathrm{A}$ & $\mathrm{A}$ & $\mathrm{A}$ \\
8. Capacitação & $\mathrm{A}$ & $\mathrm{A}$ & $\mathrm{A}$ & $\mathrm{A}$ \\
9. Rotatividade & $\mathrm{AR}$ & $\mathrm{A}$ & $\mathrm{A}$ & $\mathrm{A}$ \\
10. Benefícios & $\mathrm{A}$ & $\mathrm{A}$ & $\mathrm{AR}$ & $\mathrm{A}$ \\
11. Renda média mensal & $\mathrm{A}$ & $\mathrm{A}$ & $\mathrm{A}$ & $\mathrm{A}$ \\
12. Produtividade & $\mathrm{A}$ & $\mathrm{A}$ & $\mathrm{A}$ & $\mathrm{A}$ \\
13. Equipamentos e veículos & $\mathrm{A}$ & $\mathrm{A}$ & $\mathrm{AR}$ & $\mathrm{A}$ \\
14. Horas trabalhadas & $\mathrm{AR}$ & $\mathrm{AR}$ & $\mathrm{R}$ & $\mathrm{R}$ \\
15. Ganhos entre gêneros & $\mathrm{R}$ & $\mathrm{A}$ & $\mathrm{R}$ & $\mathrm{R}$ \\
16. Saúde no trabalho & $\mathrm{AR}$ & $\mathrm{A}$ & $\mathrm{AR}$ & $\mathrm{AR}$ \\
17. Segurança e saúde & $\mathrm{A}$ & $\mathrm{A}$ & $\mathrm{AR}$ & $\mathrm{A}$ \\
18. Uso de EPIs & $\mathrm{AR}$ & $\mathrm{A}$ & $\mathrm{A}$ & $\mathrm{A}$ \\
\hline
\end{tabular}

Notas: A - aprovado AR - aprovado com ressalvas $\quad R$ - reprovado 
No caso dos indicadores das organizações de catadores dois indicadores foram reprovados (horas trabalhadas e ganhos entre gêneros). O primeiro não foi considerado um bom indicador e sua forma de cálculo não foi aceita, pois a eles não interessa este tipo de mensuração do seu trabalho, desvinculado da produtividade (Quadro 17). O segundo porque dentre as premissas da organização cooperativa figura a igualdade de remuneração entre gêneros.

Apresentam-se no Quadro 18 os indicadores propostos nas três oficinas.

Quadro 18 - Indicadores de sustentabilidade propostos nas oficinas específicas

Indicadores de coleta seletiva

\begin{tabular}{ccc}
\hline & Org. de & SLU \\
Catadores & INSEA \\
& $\mathbf{X}$
\end{tabular}

Criar indicador para a coleta que inclua veículos.

\section{$\mathbf{X}$}

Incluir índice de diversificação de parcerias em relação às desejáveis.

Construir dois indicadores, envolvendo a relação custos do programa e ganhos sociais e ambientais.

Incluir faixas de sustentabilidade além das alta, média e baixa.

Incluir um indicador que possa medir o equilibrio entre a sustentabilidade das organizações e sustentabilidade do programa.

Indicador de limite de renda dos membros a partir da qual a prefeitura não deveria continuar subsidiando a organização

\section{$\mathbf{X}$}

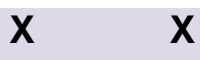

$\mathbf{X}$

$\mathbf{x}$ 
Indicadores de organizações de catadores

\begin{tabular}{|c|c|c|c|}
\hline & $\begin{array}{l}\text { Org. de } \\
\text { Catadores }\end{array}$ & SLU & INSEA \\
\hline $\begin{array}{l}\text { Incluir percentual de inclusão de catadores avulsos nas } \\
\text { organizações de catadores. }\end{array}$ & & & $\mathbf{X}$ \\
\hline - Criar um índice de parcerias & $\mathbf{X}$ & $\mathbf{X}$ & $\mathbf{X}$ \\
\hline $\begin{array}{l}\text { - Contruir um indice a partir de indicadores de cada } \\
\text { parceiro, para ponderação da importância da parceria. }\end{array}$ & & $\mathbf{x}$ & \\
\hline $\begin{array}{l}\text { Criar indicador de eficiência (produtividade) da } \\
\text { organização }{ }^{42}\end{array}$ & & & $\mathbf{X}$ \\
\hline $\begin{array}{l}\text { Criar indicador para gênero que relacione relação de } \\
\text { gênero na gestão }{ }^{43}\end{array}$ & & & $\mathbf{X}$ \\
\hline $\begin{array}{l}\text { Reclamações e sugestões, (participação) dos cidadãos } \\
\text { podem compor um indicador. }\end{array}$ & & $\mathbf{X}$ & \\
\hline Incluir o indicador de adesão da população & $\mathbf{X}$ & & $\mathbf{X}$ \\
\hline - Incluir taxa de recuperação - TRMR & $\mathbf{X}$ & & \\
\hline $\begin{array}{l}\text { - Incluir um indicador de TRMR baseado na relação } \\
\text { com o potencialmente reciclável coletado ou } \\
\text { comercializado, e não ao total dos RSD coletados. }\end{array}$ & $\mathbf{X}$ & & $\mathbf{X}$ \\
\hline Incluir taxa de rejeito & $\mathbf{X}$ & & $\mathbf{X}$ \\
\hline $\begin{array}{l}\text { indicador que possa medir o grau de autonomia da } \\
\text { organização em relação aos parceiros e prefeitura. }\end{array}$ & & $\mathbf{X}$ & \\
\hline
\end{tabular}

Em relação aos indicadores observa-se que quanto à coleta seletiva, os temas levantados pelos técnicos, apesar de consistentes, não modificam qualitativamente o resultado obtido na pesquisa Delphi, e são de difícil implementação. Quanto às organizações de catadores considerou-se a sugestão de inclusão do índice de recuperação, do índice de rejeito e a adesão da população na matriz de sustentabilidade elaborada. $O$ indicador de parcerias, embora aprovado com ressalvas segundo todos os três grupos

\footnotetext{
${ }^{42}$ Cálculo: quantidade comercializada pela organização (média últimos 6 meses) $\times 100$

${ }^{43}$ Cálculo: \% de mulheres na Diretoria $\times 100$ homens + mulheres na diretoria
} 
consultados, não foi considerado satisfatório da forma que foi apresentado. No entanto, apesar da discordância, sugerem-se componentes com formatos diferentes para a construção do índice de parcerias.

Verifica-se que nas oficinas, a maioria dos indicadores propostos foi aprovada, mesmo que com ressalvas. A natureza das ressalvas como se pode observar nos APENDICES $\mathrm{P}, \mathrm{Q}$ e $\mathrm{R}$ se refere a complementações ou propostas de alterações nos percentuais das tendências à sustentabilidade em alguns indicadores (Tabela 14).

Tabela 14- Resultados das avaliações de indicadores em oficinas específicas

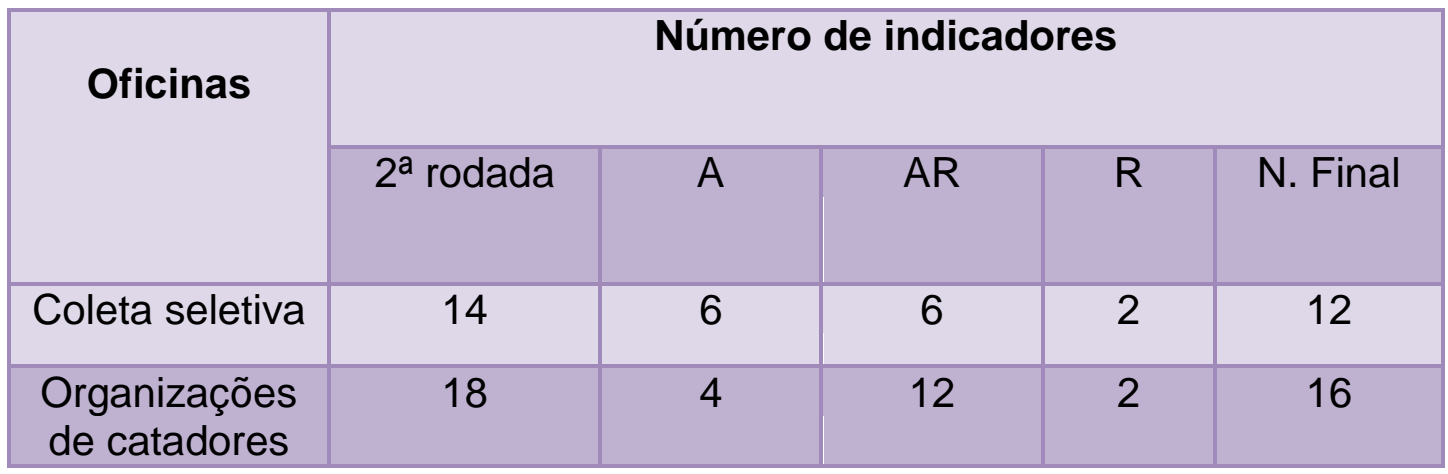

Notas: A- aprovado $\quad$ AR - aprovado com ressalvas $\quad$ R- reprovado

Os resultados obtidos no Delphi e nas oficinas, com relação aos indicadores que buscavam medir parcerias, ou condições de trabalho, existentes em relação às desejáveis apontam as limitações e ao mesmo tempo, as qualidades da técnica. Nas oficinas presenciais não houve questionamentos metodológicos sobre os indicadores que propunham medir, baseados em atendimento a requisitos ou variáveis efetivadas e desejáveis. No Delphi, os especialistas questionaram a eficiência destes indicadores enquanto instrumento de medição. 
Nas oficinas presenciais observou-se que o foco era definir com maior amplitude e coerência possível o escopo do que seria a dimensão desejável, e como medir isto da melhor forma, não tendo havido rejeição da maioria dos indicadores construídos nestas bases.

A situação descrita anteriormente confirma uma das desvantagens das respostas presenciais com relação à aplicação do Delphi individual e por meio eletrônico que é a influencia do grupo ou do pesquisador sobre o resultado da avaliação (LANDETA, 1999; WRIGHT E GIOVINAZZO, 2000; LINSTONE Y TUROFF, 2002). Também é possível que os especialistas não tenham sido suficientemente esclarecidos nos questionários sobre o motivo e o objetivo da proposição destes indicadores nos questionários.

\subsection{MATRIZES E ÍNDICES DE SUSTENTABILIDADE}

Um dos objetivos específicos desta pesquisa foi o de construir duas matrizes de sustentabilidade, uma para a coleta seletiva e outra para as organizações de catadores (Quadros 19 e 20), e a partir destas calcular os dois Índices de Sustentabilidade. Estas foram construídas a partir do processo de validação dos indicadores, das fórmulas de cálculo e das tendências à sustentabilidade. Os índices são valores numéricos que variam de 0 a 1 . A metodologia de cálculo do Índice é apresentada no Capítulo 6.

A matriz é um importante instrumento de planejamento e gestão e permite ponderar os indicadores, chegar a um índice sintético e ao mesmo tempo medir os indicadores desagregados, o que possibilita identificar os pontos mais fortes e mais fracos e planejar ações (BELLEN, 2005; GUIMARÃES, 2009; JANUZZI, 2006). Este índice possibilita também estabelecer uma comparação quanto ao desempenho na gestão entre municípios, e organizações de catadores. 
$\mathrm{Na}$ pesquisa aqui apresentada, os indicadores não foram agrupados, uma vez que o Quadro 9 mostra que estes abrangem em sua maioria várias dimensões da sustentabilidade.

Os indicadores são apresentados na ordem de importância a eles atribuída pelos especialistas.

\subsubsection{Coleta seletiva}

Em relação à coleta seletiva, dentre aqueles que têm maior aprovação (de $80 \%$ para mais), observam-se seis temas, um primeiro relacionado com a legitimidade da coleta seletiva (adesão e atendimento), um segundo aspecto relacionado com a eficiência do serviço (índice de recuperação de recicláveis e índice de rejeito), um terceiro associado com condições de trabalho nas centrais de triagem e um quarto que contextualiza a lógica da relação entre as prefeituras e as organizações. O quinto tema é relacionado aos custos e inclui três indicadores que buscam caracterizar os custos da prestação de serviço da coleta seletiva em relação à quantidade coletada, à relação custo-benefício face ao custo da coleta domiciliar e do aterramento, uma vez que inclui a quantidade de resíduos que é desviada do aterro. Este é um diferencial que aqui se apresenta e que se contrapõe à visão tradicional prevalecente (CICLOSOFT 2009) de calcular os custos da coleta seletiva em relação aos custos da coleta domiciliar. O sexto tema é relacionado com receita para viabilizar o sistema, o autofinanciamento, que depende principalmente da cobrança de taxa ou tarifa, o que de fato ainda é pouco comum no Brasil, sendo, na maior parte, cobrado junto ao Imposto sobre a Propriedade Territorial e Predial Urbano (IPTU) (SNIS, 2007). 
Outros temas como educação, inclusão de catadores e gestão compartilhada tem aprovação acima de $70 \%$ e apenas parcerias fica abaixo de $70 \%$.

Observa-se que a gestão compartilhada é muito valorizada na literatura de resíduos sólidos, entretanto se verifica que entre a teoria e a prática existe uma distância que precisa ser mais bem avaliada tanto no plano conceitual quanto da situação real. Existem diferentes entendimentos por parte dos diferentes atores envolvidos na pesquisa quanto ao significado dessa forma de gestão e as formas de avaliar seu funcionamento. Em virtude destas interpretações diferenciadas, o indicador obteve uma das menores avaliações.

Cabe destacar a decisão de manter o indicador de parcerias apresentado na segunda rodada e reprovado em suas características pelos especialistas. Isto se deve ao fato que no decorrer da pesquisa, embora todos os atores que participaram consideraram as parcerias muito importantes, não houve consenso sobre sua melhor formulação. Dada sua importância entende-se que este possa ser substituído no futuro, por um índice que contemple a diversidade e qualidade das parcerias.

Apresenta-se no Quadro 19 a Matriz de Sustentabilidade da Coleta Seletiva. Esta inclui o indicador, o peso a ele atribuído pelos especialistas, as tendências à sustentabilidade dos indicadores e o valor que varia de 0 a 1 (alta, 1 ponto, média 0,5 ponto e baixa 0 pontos). $O$ valor final é representado pela multiplicação do peso pelo valor. 
Quadro 19 - Matriz de sustentabilidade da coleta seletiva

\begin{tabular}{|c|c|c|c|c|c|c|c|}
\hline \multicolumn{8}{|c|}{ Indicadores de sustentabilidade da coleta seletiva } \\
\hline & & \multicolumn{3}{|c|}{ Tendências à sustentabilidade } & \multirow[t]{2}{*}{ Peso } & \multirow[t]{2}{*}{ Valor } & \multirow[t]{2}{*}{ V F } \\
\hline & & Alta & Média & Baixa & & & \\
\hline 1 & Adesão da população & $\geq 80 \%$ & $40,1 \%-79,9 \%$ & $\leq 40 \%$ & 0,91 & & \\
\hline 2 & Atendimento da população & $80 \%$ a $100 \%$ & $40,1 \%-79,9 \%$ & $\leq 40 \%$ & 0,90 & & \\
\hline 3 & $\begin{array}{l}\text { Taxa de recuperação de } \\
\text { recicláveis -TRMR }\end{array}$ & $\geq 20 \%$ & $10,1 \%-19,9 \%$ & $\leq 10 \%$ & 0,89 & & \\
\hline 4 & Taxa de rejeito & $\leq 10 \%$ & $10,1 \%-29,9 \%$ & $>30 \%$ & 0.87 & & \\
\hline 5 & Condições de trabalho & $80 \%$ a $100 \%$ & $50,1 \%-79 \%$ & $\leq 50 \%$ & 0,84 & & \\
\hline 6 & $\begin{array}{l}\text { Instrumentos legais na relação } \\
\text { com org. de catadores }\end{array}$ & $\begin{array}{c}\text { Contrato ou } \\
\text { Convenio } \\
\text { remunerado }\end{array}$ & $\begin{array}{c}\text { Convenio } \\
\text { sem remuneração }\end{array}$ & $\begin{array}{l}\text { Não há contrato } \\
\text { ou convenio }\end{array}$ & 0,83 & & \\
\hline 7 & $\begin{array}{l}\text { Custo do serviço/ quantidade } \\
\text { seletiva }\end{array}$ & $\leq \mathrm{R} \$ 175,00 / \mathrm{t}$ & $\mathrm{R} \$ 170,1-\mathrm{R} \$ 350,00$ & $\geq \mathrm{R} \$ 350,00 / \mathrm{t}$ & 0,82 & & \\
\hline 8 & $\begin{array}{l}\text { Custo da coleta seletiva/ regular } \\
\text { + destinação final }\end{array}$ & $\leq 50 \%$ & $50,1 \%-199,9 \%$ & $\geq 200 \%$ & 0,81 & & \\
\hline 9 & Autofinanciamento & $80 \%$ a $100 \%$ & $50,1 \%-79,9 \%$ & $\leq 50 \%$ & 0,80 & & \\
\hline 10 & Educação /divulgação & $\begin{array}{c}\text { Permanente } \\
\text { Quinzenal/Mensal }\end{array}$ & $\begin{array}{c}\text { Bimestral e } \\
\text { Trimestral }\end{array}$ & Anual/pontual & 0,79 & & \\
\hline 11 & Custo da coleta/ manejo de RS & $\leq 50 \%$ & $50,1 \%-74,9 \%$ & $\geq 75 \%$ & 0,78 & & \\
\hline 12 & Inclusão de catadores avulsos & $80 \%$ a $100 \%$ & $50,1 \%-79,9 \%$ & $\leq 50 \%$ & 0,74 & & \\
\hline 13 & Gestão compartilhada & Existe e funciona & $\begin{array}{l}\text { Existe, mas não } \\
\text { funciona }\end{array}$ & Não existe & 0,73 & & \\
\hline 14 & Parcerias & $80 \%$ a $100 \%$ & $50,1 \%-79,9 \%$ & $\leq 50 \%$ & 0,62 & & \\
\hline
\end{tabular}

Notas: VF = Valor Final $=$ Peso $x$ Valor da tendência à sustentabilidade, onde: Alta $=1$, Média $=0,5$ e Baixa $=0$. 


\subsubsection{Organizações de catadores}

Com relação aos indicadores propostos para as organizações de catadores, parte significativa deles foi bem avaliada, sendo que de um total de 21 indicadores, 75\% obteve média acima de 0,80.

Observam-se três temas, um primeiro relacionado com o funcionamento da organização (participação dos membros, regularização, instrumentos legais na relação com a prefeitura, parcerias e autogestão). O segundo está associado com a situação socioeconômica e condições de trabalho (renda, produtividade, diversificação das atividades, aspectos associados com saúde e uso de equipamentos, capacitação, benefícios, rotatividade dos membros, relação de ganhos entre gêneros). $O$ terceiro relacionado com a eficiência do serviço (taxa de recuperação de recicláveis e taxa de rejeito, adesão da população, equipamentos e veículos).

Destacam-se sete indicadores: 1) renda, 2) adesão da população, 3) segurança e salubridade do ambiente de trabalho, 4) saúde do trabalhador, 5) taxa de rejeito, 6) taxa de recuperação de materiais recicláveis e 7) participação em reuniões (Quadro 20).

Ao observar estes indicadores que tem uma média que varia de 0,87 a 0,95 , pode se verificar que os principais aspectos associados com condicionantes econômicos, sociais, organizacionais, institucionais e de saúde foram muito bem avaliados pelos especialistas. Os outros indicadores, muitos deles complementares tiveram nota média acima de 0,74 , e apenas os dois indicadores de parcerias, pelas razões já expostas ficaram abaixo desta média. Nesse caso apesar de ambos terem sido prejudicados na ponderação em função da dificuldade de medição é importante destacar que no cômputo final são dois indicadores de uma mesma categoria, parceria, portanto de certa forma estes representam um peso maior no cálculo do índice. 
Quadro 20 - Matriz de sustentabilidade das organizações de catadores

\begin{tabular}{|c|c|c|c|c|c|c|c|}
\hline \multicolumn{8}{|c|}{ Indicadores de sustentabilidade das organizações de catadores } \\
\hline & & \multicolumn{3}{|c|}{ Tendência à sustentabilidade } & \multirow{3}{*}{$\begin{array}{c}\text { Peso } \\
0,95\end{array}$} & \multirow[t]{2}{*}{ Valor* } & \multirow[t]{2}{*}{ VF } \\
\hline & & Alta & Média & Baixa & & & \\
\hline 1 & Renda média mensal por membro & $\begin{array}{l}\geq 2 \text { salários } \\
\text { mínimos }\end{array}$ & $\begin{array}{l}\text { De } 1 \text { a } 2 \text { dois } \\
\text { salários mínimos }\end{array}$ & $\begin{array}{l}\leq 1 \text { salário } \\
\text { mínimo }\end{array}$ & & & \\
\hline 2 & Adesão da população & $\geq 80 \%$ & $40,1 \%-79,9 \%$ & $\leq 40 \%$ & 0,91 & & \\
\hline 3 & Segurança e saúde do trabalho & $\geq 80 \%$ & $50,1 \%-79,9 \%$ & $\leq 50 \%$ & 0,89 & & \\
\hline 4 & Taxa de recuperação de recicláveis -TRMR & $\geq 20 \%$ & $10,1 \%-19,9 \%$ & $\leq 10 \%$ & 0,89 & & \\
\hline 5 & $\begin{array}{l}\text { Atendimento aos requisitos de saúde do } \\
\text { trabalhador }\end{array}$ & $\geq 80 \%$ & $50,1 \%-79,9 \%$ & $\leq 50 \%$ & 0,87 & & \\
\hline 6 & Uso de EPIs & $\geq 80 \%$ & $50,1 \%-79,9 \%$ & $\leq 50 \%$ & 0,87 & & \\
\hline 7 & Participação dos membros em reuniões & $\geq 80 \%$ & $50,1 \%-79,9 \%$ & $\leq 50 \%$ & 0,87 & & \\
\hline 8 & Taxa de rejeito & $\leq 10 \%$ & $10,1 \%-29,9 \%$ & $\geq 30 \%$ & 0.87 & & \\
\hline 9 & Membros capacitados em relação ao total & $\geq 80 \%$ & $50,1 \%-79,9 \%$ & $\leq 50 \%$ & 0,84 & & \\
\hline 10 & Produtividade por catador & $\geq 2$ t/mês & $1,1-1,9 \mathrm{t} / \mathrm{mês}$ & $\leq 1 \mathrm{t} /$ mês & 0,84 & & \\
\hline 11 & Regularização & $100 \%$ & $50,1-99,9 \%$ & $\leq 50 \%$ & 0,84 & & \\
\hline 12 & $\begin{array}{l}\text { Instrumentos legais na relação com a } \\
\text { prefeitura }\end{array}$ & $\geq 80 \%$ & $50,1 \%-79,9 \%$ & $\leq 50 \%$ & 0,84 & & \\
\hline
\end{tabular}




\section{Continuação: Indicadores de sustentabilidade das organizações de catadores}

\begin{tabular}{|c|c|c|c|c|c|c|c|}
\hline & & \multicolumn{3}{|c|}{ Tendência à sustentabilidade } & Peso & Valor* & VF \\
\hline 13 & $\begin{array}{l}\text { Atendimento aos requisitos de } \\
\text { autogestão }\end{array}$ & $\geq 80 \%$ & $50,1 \%-79,9 \%$ & $\leq 50 \%$ & 0,82 & & \\
\hline 15 & Benefícios aos membros & $\geq 80 \%$ & $50,1 \%-79,9 \%$ & $\leq 50 \%$ & 0,79 & & \\
\hline 16 & $\begin{array}{l}\text { Horas trabalhadas membro/ total da } \\
\text { organização }\end{array}$ & $80 \%-100 \%$ & $50,1 \%-79,9 \%$ & $\begin{array}{l}\leq 50 \% \\
\geq 100\end{array}$ & 0,77 & & \\
\hline 17 & Relação de ganhos entre gêneros & $100 \%$ & $70,1 \%-99,9 \%$ & $\leq 70 \%$ & 0,74 & & \\
\hline 18 & $\begin{array}{l}\text { Equipamentos e veículos } \\
\text { próprios/cedidos }\end{array}$ & $\geq 80 \%$ & $50,1 \%-79,9 \%$ & $\leq 50 \%$ & 0,74 & & \\
\hline 19 & $\begin{array}{l}\text { Diversificação das atividades e } \\
\text { serviços }\end{array}$ & $\geq 80 \%$ & $50,1 \%-79,9 \%$ & $\leq 50 \%$ & 0.74 & & \\
\hline 20 & Qualidade das parcerias & $\geq 80 \%$ & $50,1 \%-79,9 \%$ & $\leq 50 \%$ & 0,71 & & \\
\hline 21 & Diversificação das parcerias & $\geq 80 \%$ & $50,1 \%-79,9 \%$ & $\leq 50 \%$ & 0,66 & & \\
\hline
\end{tabular}

Notas: $\mathrm{VF}=$ Valor Final $=$ Peso $\times$ Valor da tendência à sustentabilidade, onde: Alta $=1$, Média $=0,5$ e Baixa $=0$. 
Os três indicadores acrescidos ao conjunto das organizações de catadores: 1) Taxa de recuperação de materiais recicláveis (TRMR), 2) Taxa de rejeito (TR) e 3) Adesão são calculados da mesma forma da coleta seletiva, porém leva-se em conta a à área atendida pelas organizações.

Quanto à Matriz de Sustentabilidade das Organizações de Catadores, esta foi acrescida de três indicadores em relação ao resultado final do Delphi. O motivo desta inclusão deve-se à importância dada a estes indicadores nas oficinas específicas. Em especial na oficina de organizações de catadores que consideraram a necessidade de sua inclusão. A inclusão foi possível, uma vez que estes mesmos indicadores foram avaliados pelos especialistas e ponderados para a coleta seletiva. 


\section{COMUNICAÇÃO DOS INDICADORES E ÍNDICES}

Um dos grandes desafios com relação aos indicadores e índices de sustentabilidade, além de sua legitimação pelos usuários consiste em sua comunicação para diferentes públicos. JESINGHAUS (1999) afirma que a transparência do sistema e a forma de comunicação dos resultados são fundamentais para qualquer ferramenta de avaliação de sustentabilidade.

Dois sistemas de indicadores de sustentabilidade, complexos e muito disseminados utilizam representações para a comunicação, o Dashboard of Sustainability e o Barômetro da Sustentabilidade. A palavra dashboard, ou painel, se refere ao conjunto de instrumentos de controle situado abaixo do pára-brisa de um veículo (BELLEN, 2005). A representação gráfica recente do dashboard se dá por meio de um painel visual de três grupos ou blocos de mostradores que procuram mensurar o desempenho econômico, social e ambiental de diferentes escalas territoriais ou empreendimentos (BELLEN, 2005). Trata-se de um índice agregado de vários indicadores dentro de cada um dos mostradores; e a partir do cálculo dos índices se obtém o resultado final de cada mostrador. Uma função adicional calcula a média dos mostradores e chega ao Índice de Sustentabilidade Global (Sustainable Development Index SDI).

BELLEN (2005, p.129) argumenta que HARDI (2000), "considera que esta ferramenta identifica pontos fortes e fracos e auxilia os tomadores de decisão, públicos e privados, a repensar suas estratégias de desenvolvimento e a especificação de metas e destaca tratar-se de uma apresentação atrativa e concisa da realidade que pode chamar a atenção do público-alvo".

Segundo BELLEN (2005) o Barômetro da Sustentabilidade é uma ferramenta que busca combinar indicadores e mostrar seus resultados à sociedade por meio de índices que calculam ou medem o progresso em direção 
à sustentabilidade utilizando indicadores biofísicos e de saúde social. Estes índices são apresentados com uma representação gráfica que facilita a compreensão e fornece um quadro geral do meio ambiente e da sociedade. A escala utilizada para cada um dos eixos varia de 0 a 100 pontos e o resultado e intervalos de valores se situam em cada um dos 5 setores (ruim - vermelho, pobre - rosa, médio - amarelo, razoável - azul e bom - verde).

Como abordado anteriormente no capítulo referente aos Métodos e Técnicas, a elaboração do instrumento - Radar da Sustentabilidade - inspirado no Dashboard of Sustainability visa facilitar a compreensão dos vários usuários e interessados, municípios, órgãos públicos, tomadores de decisão, organizações de catadores e a mídia quanto ao desempenho atual na gestão da coleta seletiva e suas possibilidades de melhoria.

Considera-se que instrumentos de fácil assimilação e entendimento se tornam meios cada vez mais relevantes para fortalecer práticas da sociedade para monitorar o desempenho das políticas públicas, e no presente caso a evolução da coleta seletiva com inclusão de catadores.

As Figuras 14 e 15 apresentam a visualização gráfica dos dois radares da sustentabilidade; da coleta seletiva (Figura 14) e das organizações de catadores (Figura 15). Ambos definem 4 quartis, com variações de acordo com intervalos de resultados dos índices obtidos, e definem quatro condições em relação à sustentabilidade: muito desfavorável, desfavorável, favorável e muito favorável.

O resultado obtido possibilita ao município ou à organização de catadores identificarem seu posicionamento em relação à sustentabilidade, e a partir da matriz identificar os pontos fortes e fracos e planejar suas ações para evoluir cada vez mais na direção da sustentabilidade. 
Figura 14 - Radar de Sustentabilidade da Coleta Seletiva

RADAR DA SUSTENTABILIDADE DA COLETA SELETIVA

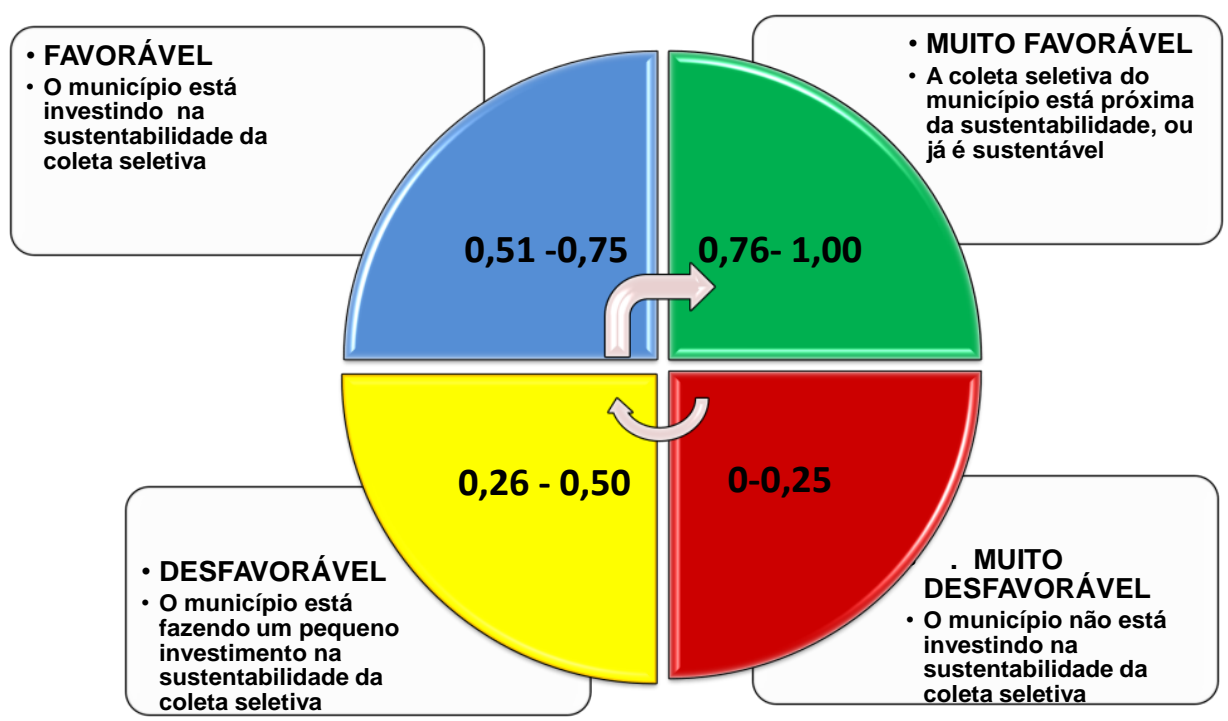

Elaborado pela autora, 2010. 
Figura 15 - Radar de Sustentabilidade das Organizações de Catadores

\section{RADAR DA SUSTENTABILIDADE DAS ORGANIZAÇÕES DE CATADORES}

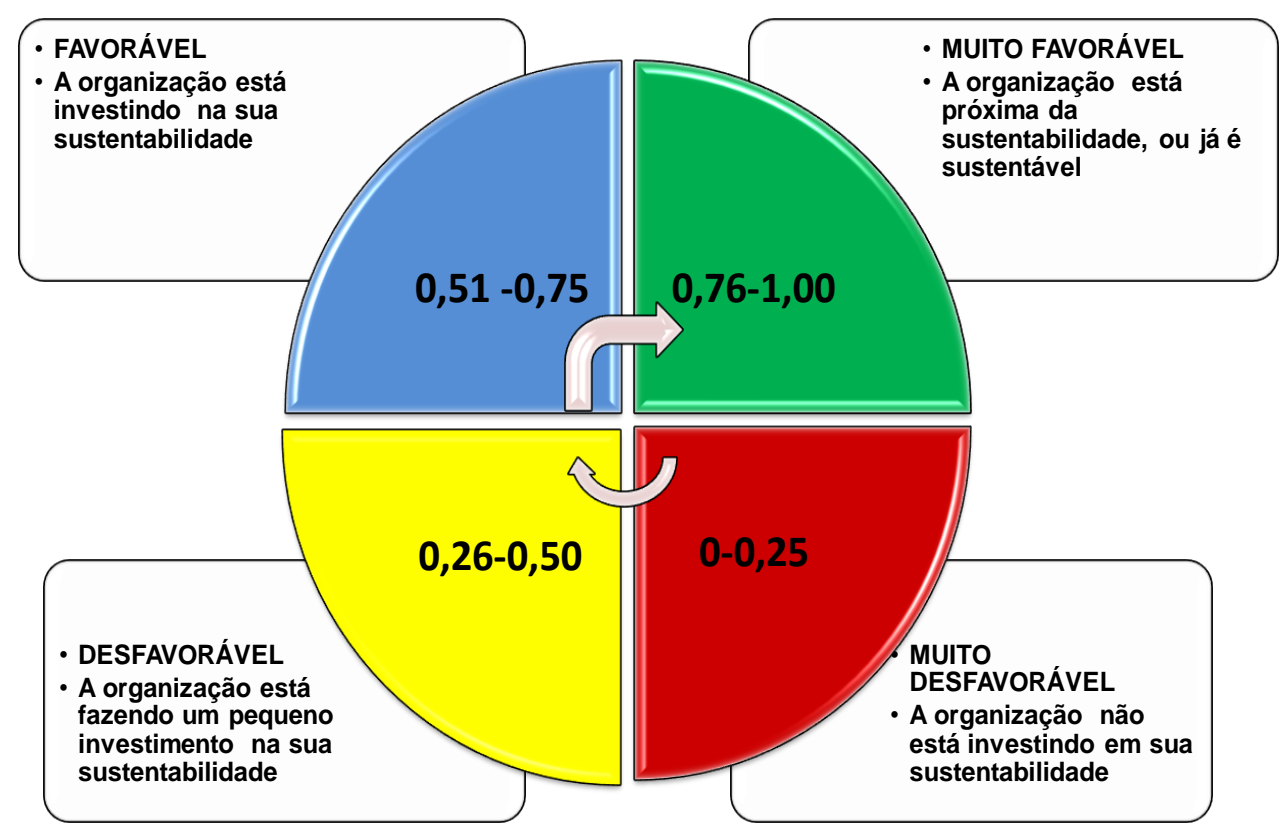

Elaborado pela autora, 2010. 
A utilização dos índices permite que os municípios avaliem suas fortalezas e fragilidades em relação à sustentabilidade e possam planejar e implementar políticas e ações, o mesmo ocorrendo para as organizações de catadores.

A partir destes índices também é possível comparar a coleta seletiva a situação da coleta seletiva na perspectiva da sustentabilidade em diferentes municípios e entre as organizações de catadores, assim como estabelecer sua hierarquização. É consenso entre especialistas sobre o tema de indicadores de sustentabilidade que embora a construção de índices por vezes seja criticada, ainda é a única forma de estabelecer comparações e estimular o desenvolvimento na perspectiva do desenvolvimento sustentável. Porém é necessário aprimorá-los cada vez mais para que se aproximem ao máximo da realidade medida.

Trabalhar com índices de sustentabilidade possibilita subsidiar políticas públicas voltadas para a questão da coleta seletiva de resíduos sólidos, ao avaliar e comparar o grau de sustentabilidade da coleta seletiva e das organizações de catadores. Contribui também nos debates que se colocam para repensar as políticas e principalmente na revisão da legislação existente ou na elaboração de nova legislação. Promove ainda, um novo nível de avaliação para os investimentos públicos e privados voltados à gestão compartilhada dos resíduos e à coleta seletiva com inclusão de organizações de catadores. 


\section{CONCLUSÕES E RECOMENDAÇÕES}

O conceito atual de gestão integrada e sustentável de resíduos sólidos, da qual o serviço de coleta seletiva faz parte, tem como pressuposto, em especial na América Latina e Caribe, a inclusão social dos catadores ou recicladores de materiais descartados pós consumo. O desenvolvimento sustentável urbano, no que se refere aos resíduos sólidos se baseia em políticas públicas voltadas à redução da produção, à reutilização de resíduos e à maximização da coleta seletiva e de seu potencial de inclusão social de catadores.

A coleta seletiva pode melhorar indiretamente a qualidade de vida da população e diretamente a dos catadores, na medida em que promove a sua saúde dentro do enfoque dos determinantes sociais e ambientais de saúde.

A existência de um alto nível de informalidade e o descompromisso da maioria das administrações municipais com a efetiva implantação de políticas de resíduos com inclusão social, algo inquestionável num país como Brasil e tantos outros na América Latina, tem mostrado a importância de fortalecer políticas mais comprometidas com a co-responsabilização de todos os atores envolvidos.

A política pública de resíduos sólidos no Brasil se pauta no fortalecimento da inclusão de catadores organizados em associações e cooperativas na prestação do serviço de coleta seletiva para os municípios. Embora apenas $18 \%$ dos municípios afirmem ter coleta seletiva, a maior parte (66\%) os executa juntamente com organizações de catadores, ainda que de forma não remunerada.

Apesar da grave crise econômica global que no ano de 2008 causou queda dos preços dos recicláveis e a falência de um grande número de empreendimentos, a tendência de crescimento de organizações de catadores e 
de municípios implantando a coleta seletiva se confirmou. Os investimentos do governo federal, ao longo dos últimos sete anos em infra-estrutura e a capacitação das organizações de catadores, assim como o protagonismo do Movimento Nacional dos Catadores, enquanto organização social representativa dos catadores, além do apoio de organizações nacionais e internacionais foram fatores decisivos para o fortalecimento deste modelo e contribuíram diretamente e significativamente para a ampliação da coleta seletiva com organizações de catadores no Brasil.

São inegáveis os avanços que os catadores obtiveram nos últimos 15 anos. A partir das iniciativas municipais de coleta seletiva, e do apoio de entidades da sociedade civil os catadores conseguiram se valorizar, organizar e evoluir de uma situação de marginalidade, exclusão social e trabalho informal e explorado para uma condição de movimento social, de abrangência nacional e com atuação articulada com redes internacionais.

A pesquisa sobre a evolução da coleta seletiva na região metropolitana de São Paulo, no período 2004 - 2010 mostrou que houve ampliação dos programas da coleta seletiva, em especial com organizações de catadores, incremento do número de organizações de catadores, do número de membros das organizações e aumento do índice de recuperação dos materiais recicláveis. No entanto também alertou para a redução da renda dos membros das organizações neste período. Além da crise econômica global de 2008 que impactou o mercado de recicláveis se destaca a ausência de remuneração das organizações de catadores pelos serviços prestados, fator que afeta diretamente a sustentabilidade financeira e a capacidade de modernização tecnológica destes empreendimentos.

Cabe destacar que se vive um momento político favorável para romper com antigas lógicas e práticas prevalecentes na área de resíduos sólidos, como também para estruturação de um novo paradigma de inclusão social e de sustentabilidade. A aprovação recente da Política Nacional de Resíduos Sólidos 
(PNRS), e sua regulamentação, devem criar mecanismos para incrementar a coleta seletiva, a remuneração das organizações de catadores pela prestação do serviço e as taxas de reciclagem dos resíduos sólidos domiciliares e especiais, assim como reduzir a disposição final no solo.

A existência de indicadores permite apoiar a PNRS ao definir metas e instrumentos para planejar, gerenciar monitorar, assim como de propor alternativas de gestão e promover o fortalecimento institucional e organizacional das organizações de catadores.

O presente trabalho se baseou em metodologia de construção de indicadores de sustentabilidade, indicadores e índices de sustentabilidade desenvolvidos na pesquisa COSELIX, coordenada pela Faculdade de Saúde Pública/USP e desenvolvida entre os anos de 2004 e 2005. A pesquisa trouxe à tona a importância de se consultar tanto especialistas quanto atores diretamente envolvidos na gestão e na prática da coleta seletiva.

Partiu-se do princípio de que é possível praticar a coleta seletiva com funcionários de prefeituras e de empresas privadas, e ela se mostrar economicamente ou ambientalmente sustentável, porém para se considerar que é sustentável (nos aspectos econômico, ambiental e social), esta deve fomentar a organização de catadores avulsos e a contratação de organizações de catadores para a prestação do serviço.

Ao longo da pesquisa foi possível avaliar as definições de sustentabilidade, os indicadores e a metodologia proposta na pesquisa COSELIX e identificar, construir e validar, novos indicadores de forma participativa, indicadores de sustentabilidade para a gestão, avaliação e monitoramento da coleta seletiva e de organizações sociais de catadores de materiais recicláveis.

A pesquisa realizada partiu de uma hipótese que foi comprovada. A sustentabilidade da prestação do serviço de coleta seletiva formal, com a integração de organizações de catadores, assim como a gestão sustentável de 
organizações de catadores pode ser avaliada a partir de um grupo de indicadores "construídos", "referendados", "aceitos" ou "validados" e legitimados por diferentes atores envolvidos na sua gestão. As formas de cálculo e as tendências à sustentabilidade também obtiveram um alto grau de convergência e contemplaram as especificidades regionais.

Verificou-se que foi possível construir de forma participativa conceitos de sustentabilidade para a coleta seletiva e para organizações de catadores que atingem um alto grau de consenso entre os participantes e o público presente nas oficinas regionais e específicas.

Os procedimentos e técnicas utilizados na pesquisa se mostraram adequados aos objetivos propostos e permitiram avançar no aprimoramento de um grupo de indicadores de referência para a gestão da coleta seletiva. Os dois conjuntos de indicadores de sustentabilidade validados, 14 indicadores de coleta seletiva e 21 indicadores de organizações de catadores são representativos e podem ser aplicados a realidades distintas, estabelecendo parâmetros para a eficiência e efetividade da prestação de serviços. Sua ponderação também pode ser definida de acordo com realidades locais, porém cabe destacar que pode dificultar a comparação entre municípios e organizações. A padronização excessiva implica em reduzir as especificidades locais (GUIMARÂES, 2009; BELLEN, 2005; VEIGA, 2009, 2010).

A validação dos indicadores permitiu a construção de duas matrizes de sustentabilidade, que constituem potencial instrumento de avaliação em vários níveis. As matrizes podem ser utilizadas tanto pela administração pública para medir seu desempenho (gestão sustentável) como para que as organizações tenham mais elementos para avaliar os resultados de suas práticas e a articulação com os diferentes parceiros e o poder público.

Para melhor comunicar os resultados foi elaborado o instrumento Radar da Sustentabilidade que indica o grau de sustentabilidade tanto da coleta 
seletiva como das organizações de catadores que os índices representam. Este instrumento facilita a comunicação com os usuários e a sociedade.

No que se refere às definições conceituais de sustentabilidade da coleta seletiva e de organizações de catadores, têm-se que as contribuições dos especialistas, na $1^{1}$ r rodada do Delphi, e apoiadas por sugestões das oficinas regionais possibilitaram complementar as definições iniciais e atingir altos graus de consenso na $2^{\mathrm{a}}$ rodada, tanto para os especialistas que participaram do Delphi quanto nas oficinas específicas.

A avaliação dos especialistas nas rodadas da aplicação da técnica Delphi dos indicadores e tendências à sustentabilidade mostrou que apesar do alto grau de concordância em muitos dos aspectos, o instrumento foi adequado para verificar as especificidades regionais, e a visão diversificada em torno do conceito de sustentabilidade. Considera-se, portanto que a utilização do instrumento contribui para um retrato das diversidades e especificidades que caracterizam um país como o Brasil. Possibilitou também a ampliação do número de indicadores a serem considerados, resultante do universo diversificado de entrevistados no plano técnico e operacional. Isto enriqueceu o conjunto de temas e permitiu também maior detalhamento e aprofundamento.

A participação de diversos atores sociais envolvidos na construção e validação desta ferramenta de avaliação pode ser considerada um passo nesse sentido. As oficinas realizadas em quatro cidades do país, assim como a aplicação de questionários a especialistas demonstraram que a metodologia utilizada para a construção dos indicadores e índices de sustentabilidade teve significativa aceitação. A opção pela realização de oficinas regionais e específicas numa perspectiva participativa possibilitou o envolvimento em um processo dinâmico que passou pela análise dos indicadores propostos, discussões sobre as escolhas estratégicas, acordos com visões compartilhadas do futuro dos atores intervenientes, pressupondo envolvimento e coresponsabilidade. 
Esta forma de negociação gera aprendizado, pois as interações estabelecem relações sociais, favorecem a contribuição dos atores participantes e abrem espaço para que a gestão esteja enraizada na sociedade na busca de mecanismos para o fortalecimento e empoderamento desses atores na perspectiva da justiça social.

Recomenda-se a aplicação dos indicadores de sustentabilidade anualmente para subsidiar as políticas públicas e a cada seis meses pelos usuários, prefeituras e organizações de catadores. Desta forma será possível testá-los e aprimorá-los, verificar quais as lacunas de dados que precisam ser produzidos ou sistematizados, e ainda monitorar a evolução do sistema de coleta seletiva e da gestão sustentável das organizações de catadores.

A pesquisa comparativa sobre a evolução da coleta seletiva na região metropolitana de São Paulo, no período entre 2004 e 2010, mostrou os grandes desafios existentes para consolidar a coleta seletiva com inclusão de catadores e a importância de se criar um Observatório de Gestão de Resíduos Sólidos da Região Metropolitana de São Paulo, com participação de diversos atores envolvidos: Universidades, Movimento Nacional de Catadores, ONGs, e instituições e órgãos do setor público e privado.

Para concluir se recomenda também um processo de validação dos Indicadores das Organizações de Catadores junto ao Movimento Nacional dos Catadores de Materiais Recicláveis para a sua aplicação nas mais de 500 organizações que o integram.

O desafio atual é a disseminação desses indicadores para que possam ser aplicados e aprimorados, contribuindo para a consolidação da gestão sustentável dos resíduos sólidos urbanos com inclusão socioprodutiva de catadores. Para tanto se torna importante que as agências governamentais de produção de estatísticas integrem estes indicadores, ou parte deles aos seus sistemas de levantamento de dados, por exemplo, o SNIS e/ou a Pesquisa de Informações Básicas Municipais (MUNIC), do IBGE. 


\section{REFERÊNCIAS}

ABRELPE - Associação Brasileira de Empresas de Limpeza Pública e Resíduos Especiais. Panorama de Resíduos Sólidos no Brasil- 2006. ABRELPE. São Paulo, 2006.

ABRELPE - Associação Brasileira de Empresas de Limpeza Pública e Resíduos Especiais. Panorama de Resíduos Sólidos no Brasil- 2009. ABRELPE. São Paulo, 2009.

ABREU, M. F. Do lixo à cidadania: estratégias para a ação. Brasília: Caixa, 2001.

ABREU, M. F. Coleta seletiva com inclusão social: em municípios, empresas, instituições, condomínios, escolas. Belo Horizonte: CREA-MG, 2008.

ACSELRAD, $H$. Justiça Ambiental e Construção Social do Risco. Desenvolvimento e Meio Ambiente. Curitiba: Ed. UFPR, v. 5, p. 49-60, 2002.

ACURIO, G., ROSSIN, A. TEIXEIRA, P.F. Diagnóstico de la situacion del manejo de resíduos sólidos em América Latina e Caribe: Banco Interamericano de Desarrollo/OPS: Washington, D. C.1997.

ADEDIPE N.O. et al. Waste management, processing, and detoxification. In: CHOPRA, K. (Ed) et al. Millennium Ecosystems Assessment. Ecosystems and Human Well-Being: Policy Responses: findings of the Responses Working Group. Washington DC: Island Pres, v. 3, p. 313-334, 2005.

AGENDA 21. Conferência das Nações Unidas sobre meio ambiente e desenvolvimento. Secretaria de Estado do Meio Ambiente de São Paulo; São Paulo, 1997.

ALENCAR, B. S. Emergência de novos atores no desenvolvimento sustentável: a contribuição dos catadores de materiais recicláveis no Brasil. 2008. 263 p. Tese (Doutorado em Desenvolvimento Urbano) Universidade Federal de Pernambuco. Recife.

ALI, M. Final Report on Private Sector Involvement in SWM in Karachi. London, DFID Report, 1993.

ARNSTEIN, S. Uma escada de participação cidadã. Revista Participe, Porto Alegre: v. 2, n. 2, 2002. 
AQUINO, I. F.; CASTILHO, Jr. A. B.; PIRES T. S. de L. A organização em rede dos catadores de materiais recicláveis na cadeia produtiva reversa de pós consumo na região da grande Florianópolis: uma alternativa de agregação de valor. São Carlos: Gest. Prod., v.16, n.1, p.15-24, jan-mar, 2009.

BAEDER, A. M. Educação Ambiental e mobilização social: formação de catadores na Grande São Paulo. 2009. 238 p. Tese (Doutorado em Educação) - Faculdade de Educação, Universidade de São Paulo. São Paulo.

BALLESTER, V. A. C.; DIAZ, R. M.; SIURANA, M. C. S. Indicators validation for the improvement of environmental and social impact quantitative assessment. Environmental Impact Assessment Review, Amsterdam: Elsevier, n. 26, p. $79-105,2006$.

BARTONE, C.; LEITE, L.; TRICHE, T.; SCHERTENLEIB, R. "Private Sector Participation in Municipal Solid Waste Services: Experiences in Latin America", Waste Management and Research, New York: Pergamon, v. 9, 1991.

BARTONE, C. Strategies for improving municipal solid waste management: lessons from a decade of World Bank lending. In: REGIONAL CONFERENCE 'PARTNERSHIP IN MUNICIPAL SOLID WASTE MANAGEMENT', 10-12 April 2000, Cairo. World Bank, Washington DC, USA, 2000.

BAUD, I.; POST, J. Between market and partnerships: Urban Solid Waste Management and contributions to sustainable development.GBER, Lancashire: v. 3, n.1, p 46-65, 2003.

BELL, S.; MORSE, S. Sustainability indicators: measuring the. Immeasurable. Londres: Earthscan, 1999.

BELLEN, H. M. V. Indicadores de sustentabilidade: uma análise comparativa. Rio de Janeiro: FGV, 2006.

BESEN, G. R. Programas municipais de coleta seletiva em parceria com Organizações de catadores na Região Metropolitana de São Paulo. 2006. 193 p. Dissertação (Mestrado em Saúde Pública)- Faculdade de Saúde Pública da Universidade de São Paulo. São Paulo.

BESEN, G. R. Sustentabilidade dos Programas de Coleta Seletiva com Inclusão Social: avanços, desafios e indicadores. In: IV Encontro Nacional da Associação de Pós Graduação e Pesquisa em Ambiente e Sociedade - Anppas 4 a 6 de junho de 2008, Brasília (DF) - Brasil. Disponível em: < http://www.anppas.org.br/encontro4/cd/ARQUIVOS/GT6-403-13520080509143212.pdf>. Acesso em: 5 fev. 2011. 
BESEN, G. R.; RIBEIRO, H.; JACOBI, P. R; GÜNTHER, W.M.R.; DEMAJOROVIC, J. Evaluation of sustainability of Municipal Programs of Selective Waste Collection of Recyclables in Partnership with Scavengers Organizations in Metropolitan São Paulo. In: KURIAN J.; NAGENDRAN R.; THANASEKARAN. K. (Org.). Sustainable Solid Waste Management. Chennai; Allied Publishers, p. 90-96, 2007.

BESEN, G. R.; RIBEIRO, H. Indicadores de sustentabilidade para programas municipais de coleta seletiva - métodos e técnicas de avaliação. In: governança ambiental e indicadores de sustentabilidade. In: MALHEIROS T F.; PHILIPPI A. JR.; COUTINHO S. M. V. (Org.). GOVERNANÇA AMBIENTAL E INDICADORES DE SUSTENTABILIDADE: WIPIS 2008, São Carlos: EESC/USP, p 159-174, 2008. Disponível em:

<http://hygeia.fsp.usp.br/siades/documentos/publicacoes/anais_wipis\%202008. pdf $>$. Acesso em: 15 out. 2010.

BESEN, G. R; GÜNTHER, W. M. R.; RODRIGUEZ, A. C.; BRASIL, A. L. Resíduos sólidos: vulnerabilidades e perspectivas. In: SALDIVA P. et al. Meio Ambiente e Saúde: o desafio das metrópoles. São Paulo, Ex Libris, 2010.

BOSSEL, H. Indicators for sustainable development: theory, method, applications - a report to the Balaton Group. Manitoba: Internacional Institute for Sustainable Development. 1999. Disponível em:

<http://www.iisd.org/pdf/balatonreport.pdf>. Acesso em: 20 set. 2002.

BOURDIEU, P. O Capital Social: notas provisórias. In; NOGUEIRA, M. A.; CATANI, A. Escritos de Educação. Petrópolis: Vozes, 1998.

BRASIL- Ministério da Saúde. Comissão Nacional sobre Determinantes Sociais da Saúde. As causas sociais das iniqüidades em saúde no Brasil.Relatório Final. CNDSS, 2008. Disponível em:

<http://determinantes.saude.homolog.bvs.br/lildbi/docsonline/6/1/016-

Relatorio.pdf>. Acesso em: 10 set. 2010.

BRINGHENTI, J. Coleta seletiva de resíduos sólidos urbanos: aspectos operacionais e da participação da população. 2004. Tese (Doutorado em Saúde Pública)-Faculdade de Saúde Pública - Universidade de São Paulo, São Paulo.

BURSZTYN, M. Da pobreza à miséria, da miséria à exclusão: o caso das populações de rua. In: BURSZTYN, M. (Org.). No meio da rua: nômades, excluídos e viradores. Rio de Janeiro: Garamond, 2000. 
CALDERONI, S. Os bilhões perdidos no lixo. 2a ed. São Paulo: Humanitas; 1998.

CAMPANI, D. B.; RAMOS, G. G. C.; WARTCHOW, D.; ZANINI, D.; MARTIN, C. G. Desenvolvimento de Indicadores socioambientais para o programa de coleta seletiva do município de São Leopoldo. In: 2o FÓRUM INTERNACIONAL DE RESÍDUOS SÓLIDOS- 8 a 10 julho 2009, Porto Alegre (RS). Disponível em:

<www.institutoventuri.com.br/t015.pdf>. Acesso em: 12 set. 2010.

CAPELINI, M.; MANSOR, M. T. C.; CARVALHO, C. T. R. L; FILET, M.; CAMARÃO, T. C. R. C. Estudo de um índice de gestão de resíduos sólidos urbanos para o estado de São Paulo. In: 25 CONGRESSO BRASILEIRO DE ENGENHARIA SANITÁRIA E AMBIENTAL. 20 a 25 de setembro 2009, Recife (PE).

CASTELLS, M. O Poder da Identidade. São Paulo: Paz e Terra, 1999.

CASTRO-BONAÑO, J. M. Indicadores de Desarrollo Sostenible Urbano, Una Aplicación para Andalucía. Málaga: Universidad de Málaga, 2002. Disponível em: <http://www.eumed.net/tesis/jmc/index.htm>. Acesso em: 12 mai. 2008.

CEMPRE - Compromisso Empresarial para a Reciclagem. PESQUISA CICLOSOFT. Disponível em <www.cempre.org.br>. Acesso em: 1 dez. 2008.

CEMPRE 2010. Fichas técnicas. Composto Urbano. Disponível em: $<$ http://www.cempre.org.br/fichas_tecnicas.php?Ink=ft_composto_urbano.php> Acesso em: 3 jan. 2010.

CEMPRE. Linhas de crédito do BNDES apóiam cooperativas. CEMPREINFORMA, n. 109 jan/fev., 2010. Disponível em:

<http://www.cempre.org.br/cempre_informa.php?Ink=ci_20100102_reciclando.p hp>. Acesso em: 30 set. 2010.

CENTCOOP-DF- CENTRAL DAS COOPERATIVAS DO DISTRITO FEDERAL. Diagnóstico das organizações de catadores de materiais recicláveis do Distrito Federal. Disponível em: <

http://www.coletasolidaria.gov.br/menu/material-deapoio/Diagnostico.pdf/view>. Acesso em: 20 set. 2010.

CETESB - Companhia de Tecnologia de Saneamento Ambiental. São Paulo. Inventário estadual de resíduos sólidos domiciliares - 2004. São Paulo, CETESB, 2005.2 Disponível em: http://www.cetesb.sp.gov.br/solo/publicacoes.asp >. Acesso em: 20 set. 2010 
CETESB - Companhia de Tecnologia de Saneamento Ambiental. São Paulo. Inventário estadual de resíduos sólidos domiciliares -2005. São Paulo. CETESB, 2006. Disponível em: < http://www.cetesb.sp.gov.br/solo/publicacoes.asp>. Acesso em: 20 set. 2010

CETESB - Companhia de Tecnologia de Saneamento Ambiental. São Paulo. Inventário estadual de resíduos sólidos domiciliares -2006. São Paulo. CETESB, 2007. Disponível em:

<http://www.cetesb.sp.gov.br/solo/publicacoes.asp>. Acesso em: 20 set. 2010.

CETESB - Companhia de Tecnologia de Saneamento Ambiental. São Paulo. Inventário estadual de resíduos sólidos domiciliares - 2007. São Paulo. CETESB, 2008. Disponível em: <http://www.cetesb.sp.gov.br/solo/publicacoes.asp>. Acesso em: 20 set. 2010.

CETESB - Companhia de Tecnologia de Saneamento Ambiental. São Paulo. Inventário estadual de resíduos sólidos domiciliares - 2008. São Paulo. CETESB, 2009. Disponível em:

<http://www.cetesb.sp.gov.br/solo/publicacoes.asp>. Acesso em: 20 set. 2010.

CETESB - Companhia de Tecnologia de Saneamento Ambiental. São Paulo. Inventário estadual de resíduos sólidos domiciliares - 2009. São Paulo. CETESB, 2010. Disponível em:

<http://www.cetesb.sp.gov.br/solo/publicacoes.asp> Acesso em: 20 set. 2010.

COINTREAU-LEVINE, S. Private Sector Participation in Municipal Solid Waste Management Services in Developing Countries. The Formal Sector, v.1, UNDP/UNCHS/The World Bank - Urban Management Programme, 1994.

CONCEIÇÃO, M. Os empresários do lixo: um paradoxo da modernidade: análise interdisciplinar das cooperativas de reciclagem. Campinas: Átomo, 2003.

CORVALAN, C.; BRIGGS, D.; ZIELHUIS, G. Decision-Making in Environmental Health: From evidence to action. WHO, 2000.

CRIVELLARI, M. T; DIAS, S. M.; PENA, A. S. Informação e trabalho: uma leitura sobre os catadores de material reciclável a partir das bases públicas de dados. In: KEMP, V. H.; CRIVELLARI, M. T. (Orgs.). Catadores na cena urbana: construção de políticas socioambientais. Belo Horizonte: Autêntica, 2008, p. 299-324. 
DAGNINO, E. "Sociedade Civil, Espaços Públicos e a Construção Democrática no Brasil: limites e possibilidades". In: DAGNINO, E. (Org.) Sociedade Civil e Espaços Públicos no Brasil. São Paulo: Paz e Terra, 2002.

DAMASIO, J. et al. (Cord). Cadeia Produtiva da Reciclagem e Organizações de Redes de Cooperativas de Catadores: Oportunidades e elementos críticos para a construção de tecnologia social de combate à pobreza e inclusão social no estado da Bahia. Relatório Final. Salvador, 2008.

DEMAJOROVIC, J.; BESEN, G. R.; RATHSAM, A. A. Os desafios da gestão compartilhada de resíduos sólidos face à lógica do mercado. In: JACOBI, P., FERREIRA, L. (Orgs.). Diálogos em Ambiente e Sociedade. São Paulo: Annablume, 2006. p 389-410.

DEUS, A. B. S.; LUCA, S. J.; CLARKE, R. T. Índice do Impacto dos resíduos sólidos urbanos na saúde pública (IIRSP): metodologia e aplicação. Eng. Sanit. Ambient., v.9, n. 4, p. 329-334, out./dez. 2004.

DIAS, S. M. Coleta Seletiva e inserção Cidadã: a parceria Poder Público/ASMARE em Belo Horizonte. In: JACOBI P. (Org.). Gestão Compartilhada de Resíduos Sólidos no Brasil- inovação com inclusão social. São Paulo: Annablume, 2006. p. 65-86.

DIAS, S. M. Trajetórias e memórias dos Fóruns Lixo e Cidadania no Brasil: experimentos singulares de justiça social e governança participativa. 2009. 326 p. Tese (Doutorado em Ciência Política)-Faculdade de Filosofia e Ciências Humanas, Universidade Federal de Minas Gerais, Belo Horizonte.

DIAS, S. M.; ALVES, F. C. G. Integration of the Informal Recycling Sector in Solid Waste Management in Brazil. Study prepared for GTZ's sector projet.

"Promotion of concepts for pro-poor and environmentally friendly closedloop approaches in solid waste management". 2008. (unpublished).

DORVIL, L. Private Sector Participation in Integrated Sustainable Solid waste Management in Low and Middle Income Countries. Dissertation Doctor Oeconomiae. University of St. Gallen, Graduate School of Business Administration, Economics, law and Social Sciences, 2007.

DOYLE, Y. et al. Healthy cities indicators: analysis of data from cities across Europe. Copenhague: Organização Mundial da Saúde, 1997.

EIGENHEER, E. M. Lixo, Vanitas e Morte: Considerações de um observador de resíduos. Niterói: EdUFF, 2003. 
EEA - European Environment Agency. About environment and health. Disponível em: <http://www.eea.europa.eu/themes/human/about-environmentand-health>. Acesso em: 12 set. 2010.

EPA - Environment Protection Agency. Climate Change and Waste. Reducing Waste Can Make a Difference. Disponível em:

<http://www.epa.gov/epawaste/nonhaz/municipal/pubs/ghg/climfold.pdf.>.

Acesso em: 3 set. 2010.

ESCOREL, S. Vidas ao Léu - Trajetórias de exclusão social. Rio de Janeiro: Fiocruz, 1999.

ESI - ENVIRONMENTAL SUSTAINABILITY INDEX. Disponível em:

<http://www.ciesin.columbia.edu/indicators/ESI/>. Acesso: 7 out. 2006.

ESTY, D.; PORTER, M. National Environmental Performance: measurements and determinants - the global report 2001-2002. Oxford: Oxford Press, 2002.

EUROPEAN FOUNDATION FOR THE IMPROVEMENT OF LIVING AND WORKING CONDITIONS. Urban Sustainability Indicators Office for Official Publications of the European Communities. Luxembourg, 1998.

FARAH, M. F. S. Parcerias, novos arranjos institucionais e políticas públicas no nível local de governo. RAP, Rio de Janeiro: n. 35, v.1. p. 119-144, jan. /fev. 2001.

FERNANDEZ, A. L. Public-private Partnerships in Solid Waste Management. Regional Development. Dialogue, Nagoya: n. 3, v.14, p. 3-23, 1993.

FINGER, M.; PRINCEN, T. Environmental NGOs in World Politics. Londres: Routledge, 1994.

FRAGKOU, M. C. Evaluation of urban sustainability through a metabolic perspective: application in a Mediterranean costal region. 2009. 189 p.PhD thesis. (PhD Programme in Environmental Sciences)-Universitat Autónoma de Barcelona, Barcelona.

FUNTOWICZ, S., STRAND, R. De la demonstración experta al diálogo participativo.

GALLOPIN, G. C. Environmental and sustainability indicators and the concept of situational indicators: a system approach. Environmental Modelling \& Assessment, n. 1, p. 101-117, 1996. 
GENTIL, V. Pessoas residuais e os resíduos das pessoas: uma análise do desenvolvimento mercadológico do Distrito Federal - DF. 2008. 154 p. Dissertação de Mestrado de Desenvolvimento Sustentável- Universidade de Brasília - UNB. Centro de Desenvolvimento Sustentável- CDS.

GIDDENS, A. Conseqüências da Modernidade. São Paulo: Ed. Unesp, 1992.

GLEISER, K. Toxicity Reduction. In: TCHOBANOGLOUS, G (Org.); FRANK, K (Co-Org). Handbook of solid waste management. 2 ed. Mc Graw - Hill; 2002.

GOHN, M. G. Empoderamento e participação da comunidade em políticas sociais, Saúde e sociedade, São Paulo: v. 13 n.2, p. 20-31, 2004.

GONZALEZ, J.; CADENA, M.; SUREMAIN, M. Estudio Sobre los Circuitos de Reciclaje de Desechos Sólidos en la Ciudad de Bogotá. Bogotá: ENDA America Latina, 1993.

GOUVEIA, N. C. Espaço, ambiente e saúde: um olhar epidemiológico. 2009. 124 p. Tese (Livre - docência em Medicina)-Faculdade de Medicina, Universidade de São Paulo, São Paulo.

GRAFAKOS, S.; BAUD, I. Alliances in urban environmental management: a search for indicators and contributions to sustainability. Draft synthesis report. Amsterdam: AGIDS/IJWEP, 1999.

GRAFAKOS, S.; BAUD, I.; KLUNDERT, A. Alliances in Urban Environmental Management. A process analysis for indicators and contributions to sustainable development in urban SWM. Working document 14. Netherlands: University of Amsterdam, 2001.

GRIMBERG, E. Coleta seletiva com inclusão de catadores: Fórum Lixo e Cidadania da Cidade de São Paulo: experiência e desafios. São Paulo: Instituto Pólis, 2007.

GRANJA S. I. B. Negociação na governança da água: inovações na construção de consensos em Comitês de bacia Hidrográfica. 2008. 311 p. Dissertação (Doutorado em Ciência Ambiental)-Programa de Ciência Ambiental, Universidade de São Paulo, São Paulo.

GTZ - Deutsche Gessellschaft fur Technische Zusammenarbeit. Partnerships for Recycling Management. The Waste Experts: Enabling Conditions for Informal Sector Integration in Solid Waste Management. Lessons learned from Brasil, Egypt and India. Eschborn, 2010. 
GUIMARÃES, R. P. Desenvolvimento sustentável: da retórica à formulação de políticas públicas. In: BECKER, B. K.; MITANDA, M. (Org.). A geografia política e o desenvolvimento sustentável. Rio de Janeiro: Editora UFRJ, p.13-44, 1997.

GUIMARÃES, R. P.; FEICHAS, S. A. Q. Desafios na construção de indicadores de sustentabilidade. Ambiente \& Sociedade, São Paulo: Annablume, v.XII, n.2, p. jul./dez. 2009.

GÜNTHER, W. M. R.; GRIMBERG, E. Directrices para la gestión integrada y sostenible de residuos sólidos urbanos en America Latina y el Caribe. 1. ed. São Paulo: Asociación Interamericana de Ingeniería Sanitária y AmbientalAIDIS, 2006.

GÜNTHER, W. M. R.; BESEN, G. R.; JACOBI, P. R.; RIBEIRO, H.; VIVEIROS, $M$. Construção de indicadores de sustentabilidade de programas municipais de coleta seletiva e organizações de catadores - desafios conceituais e metodológicos. In: 24ํㅡㄹ Congresso Brasileiro de Engenharia Sanitária e Ambiental, 2007, Belo Horizonte. Anais do 24ํㅡㄹ Congresso Brasileiro de Engenharia Sanitária e Ambiental. Belo Horizonte: ABES - Associação Brasileira de Engenharia Sanitária e Ambiental, v. único, p. 1-8, 2007.

GÜNTHER, W. M. R.; RIBEIRO, H.; BESEN, G. R; JACOBI, P. R.; DEMAJOROVIC, J. Programas de Coleta seletiva em parceria com organizações de catadores: indicadores de sustentabilidade. IN: ISWA BEACON CONFERENCE, 2006, SÃO PAULO. Proceedings of ISWA Beacon Conference. São Paulo: Ministério do Meio Ambiente, p. 1-15, 2006.

GUTTBERLET, J. BAEDER, A. Informal recycling and ocupacional health in Santo André, Brazil. International Journal of Environmental Health Research, Abingdon: 18:1, p. 1-15, 2008.

HABERMAS, J. A nova intransparência: a crise do estado de bem-estar social e o esgotamento das energias utópicas. Novos Estudos CEBRAP, São Paulo: n.18, p.103-114, 1987.

HARDI, P. The Dashboard of sustainability. Winnipeg, 2000. (Working paper).

HARDOY, J. E.; MITLIN, D.; SATTERTHWAITE, D. Environmental Problems in Third World Cities. London: Earthscan Publications, 1992.

HARDOY, J. E.; MITLIN, D.; SATTERTHWAITE, D. Environmental Problems in an Urbanizing World, Local Solutions for City Problems in Africa, Asia and Latin America. London: Earthscan Publications, 2001. 
IBGE - INSTITUTO BRASILEIRO DE GEOGRAFIA E ESTATÍSTICA. Pesquisa Nacional por Amostra de Domicílios 2004. Rio de Janeiro: IBGE; 2004.

IBGE - INSTITUTO BRASILEIRO DE GEOGRAFIA E ESTATÍSTICA. Pesquisa Nacional de Saneamento Básico, 2008. Rio de Janeiro: IBGE; 2010a.

IBGE - INSTITUTO BRASILEIRO DE GEOGRAFIA E ESTATÍSTICA. Indicadores de Desenvolvimento Sustentável: Brasil 2008. Rio de Janeiro: IBGE; 2010b.

INSTITUTO ETHOS. Vínculos de Negócios Sustentáveis em Resíduos sólidos. São Paulo, INSTITUTO ETHOS/ FUNDAÇÃO AVINA, 2007.

INSTITUTO PÓLIS. Documento Encontro Nacional 2006- Construindo Políticas Públicas para a Recuperação e Reciclagem de Resíduos Sólidos com Inclusão dos Catadores. Instituto Pólis. São Paulo, 2006.

IPEA - INSTITUTO DE PESQUISA ECONÔMICA APLICADA. Pesquisa sobre pagamento por serviços ambientais urbanos para gestão de resíduos sólidos. Relatório de Pesquisa. Brasília, 2010.

JACOBI, P. R. Políticas sociais e ampliação da cidadania. Rio de Janeiro: FGV, 2000.

JACOBI, P. R. Meio ambiente e redes sociais: dimensões intersetoriais e complexidade na articulação de práticas coletiva. RAP, Rio de Janeiro: FGV, v. 34, n.6, p. 131-158, nov./dez., 2000.

JACOBI, P. R.; BESEN, G. R. Gestão de resíduos sólidos na Região Metropolitana de São Paulo: avanços e desafios. São Paulo em Perspectiva. São Paulo: Fundação Seade, v. 20, n. 2, p. 90-104, abr./jun. 2006.

JACOBI, P. R; GRANJA, S. I. B.; FRANCO, M. I. Aprendizagem Social: práticas educativas e participação da sociedade civil como estratégias de aprimoramento para a gestão compartilhada em bacias hidrográficas. São Paulo em Perspectiva, São Paulo: Fundação Seade, v. 20, n. 2, p.5-18, abr./jun. 2006.

JACOBI, P. R. (Org.). Gestão Compartilhada de Resíduos Sólidos no Brasilinovação com inclusão social. São Paulo: Annablume, 2006.

JANNUZZI, P. de M. Indicadores Sociais no Brasil. Campinas: Alínea, 2006. 
JANNUZZI, P. de M. Considerações sobre o uso, mau uso e abuso dos indicadores sociais na formulação e avaliação de políticas públicas municipais. Revista de Administração Pública, Rio de Janeiro: v. 36, n.1, p.51-72, jan./fev.2002.

JESINGHAUS, J. Indicators for decision making. European Comission. JRC/ISIS/MIA, TP 361, Ispra (VA), 1999.

KAYNAK, E.; MACAULEY, J. A. The Delphi technique in the measurement of turism market potential: The case of Nova Scotia. Tourism Management, Amsterdam: Elsevier, v.5, p. 87-101, 1984.

KLUNDERT, A.; ANSCHIITZ, J. The sustainability of alliances between stakeholders in waste management -using the concept of integrated Sustainable Waste Management- Working paper. Netherlands:UWEP/CWG, 2000.

KLUNDER, A.; ANSCHÜTZ, J.; SCHEINBERG, A. Concept of ISWM, Gouda: WASTE, 2001.

LANDETA, J. El metodo Delphi. Barcelona: Ariel, 1999.

LARDINOIS, I. Integrated Sustainable Waste Management: concept and examples from Latin-America. Lecture at the seminar on Sustainable Urban Development in Developing Countries. GOUDA: Waste, IIUE and NLTHG, 1996.

LARDINOIS, I.; KLUNDERT, A. Community and private (formal and informal) sector involvement in municipal solid waste management in developing countries. Background paper for the UMP workshop in Ittingen, Switzerland, Gouda: WASTE, 1995.

LAVALLE, G. A.; CASTELlO, G.; BICHIR, M. R. "Os Bastidores da Sociedade Civil - Protagonismos, Redes e Afinidades no Seio das Organizações Civis". Centro Brasileiro de Análise e Planejamento - CEBRAP, São Paulo, 2006.

LIMA, R. M. S. R. Implantação de um programa de coleta seletiva porta a porta com inclusão de catadores: estudo de caso em Londrina - PR. 2006. 173 p. Dissertação (Mestrado em Engenharia de Edificações e Saneamento) Universidade Estadual de Londrina, Londrina.

LIMA, F. P. A.; OLIVEIRA, F. G. Produtividade técnica e social das associações de catadores: por um modelo de reciclagem solidária. In: KEMP V. H.; 
CRIVELLARI M. T. (Orgs.). Catadores na cena urbana: construção de políticas socioambientais. Belo Horizonte: Autêntica, p.225-248, 2008.

LINSTONE, H. A.; TUROFF, M. (Orgs). The Delphi Method: Techniques and Aplicattions, 2002. Newark: New Jersey Institute of Technology. Disponível em: <http://is.njit.edu/pubs/delphibook/>. Acesso em: 10 maio. 2008.

MARTINEZ, E. B.; CARPI, J. A. T. Residuos urbanos y sustentabilidad ambiental: estado de la question y debate em la Comunidad Valenciana. Espanha: Instituto Mediterráneo para el Desarrollo Sostenible-IMEDEUniversitat de Valência, 2006.

MARTINS, C. Trabalhadores na Reciclagem do Lixo: dinâmicas econômicas, sócio-ambientais e políticas na perspectiva de empoderamento. 2004. 210 p. Tese (Doutorado em Sociologia)-Faculdade de Sociologia - Universidade Federal do Rio Grande do Sul, Porto Alegre.

MEADOWS, D. Indicators and information system for sustainable development: a report to the Balaton Group. Hartland four Corners: The Sustainable Institute, 1998.

MEDINA, M. Informal Recycling and Collection of Solid Wastes in Developing Countries: Issues and Opportunities. Tokyo: United Nations University / Institute of Advanced Studies. Working Paper, n. 24, p.1-2, 1997.

MEDINA, M. Scavenger Cooperatives in Asia and Latin America. 2006. Disponível em: <http://www.gdnet.org/pdf/medina.pdf>. Acesso em: 5 out. 2009.

MEDINA, M. The World's Scavangers: salvaging for Sustainable consumption and production. Lanham MD: Altamira Press, 2007.

MILANEZ, B. Resíduos sólidos e sustentabilidade: princípios, indicadores e instrumentos de ação. 2002. 206 p. Dissertação (Mestrado em Engenharia Urbana) - Universidade Federal de São Carlos, São Carlos.

MIRANDA, A. B. Sistemas urbanos de água e esgoto: princípios e indicadores de sustentabilidade. 2003. 133 p. Dissertação (Mestrado em Engenharia Urbana) - Universidade Federal de São Carlos, São Carlos.

MIRANDA, A. B.; TEIXEIRA, B. A. N. Indicadores de sustentabilidade para os sistemas urbanos de água e esgoto: escolha ampliada. Disponível em: $<$ http://www.semasa.sp.gov.br/Documentos/ASSEMAE/Trab_91.pdf>. Acesso em: 3 out. 2010. 
MITLIN, D. Civil Society and Urban Poverty, Examining the Complexity, Environment and Urbanization, Londres: v. 13, n. 2, p. 151-173, 2001.

MONTIBELLER, G. F. Indicadores e equidade social: propriedades dos indicadores de sustentabilidade e ausência do princípio de justiça social em estudos sobre mudança climática e $\mathrm{CO}_{2}$. Interdisc. R. Inter. Antithesis, Florianópolis, v.7, n.1, p. 199-221, jan./ jul., 2010.

MORENO, J.A.; RIOS, F.R.; LARDINOIS, I. Solid waste management in Latin America: the role of micro- and small enterprises and co-operatives. IPES/ACEPESAIWASTE. Urban Waste Series, Gouda: Waste, n. 5, 1999.

MNCR - MOVIMENTO NACIONAL DOS CATADORES DE MATERIAS RECICLÁVEIS. Análise do custo de geração de postos de trabalho na economia urbana para o segmento dos catadores de materiais recicláveis. Relatório Técnico Final. Janeiro de 2006.

MTE - MINISTÉRIO DO TRABALHO E EMPREGO. Atlas da Economia Solidária no Brasil 2005. MTE, SENAES, Brasília, 2006.

MUNHOZ, C. P. A situação do trabalho das cooperativas de catadores frente à valorização econômica da reciclagem. 2004. Dissertação p. (Mestrado em Saúde Pública) - Faculdade de Saúde Pública, Universidade de São Paulo São Paulo, USP.

NAS, P.; JAFFE, R. Informal waste management shifting the focus from problem to potential. Environment Development and Sustainability, Berlin: v. 6, p. 337-353, 2004.

NOBRE, C. A. et al. Vulnerabilidades das Megacidades Brasileiras às Mudanças Climáticas - Região Metropolitana de São Paulo. Sumário Executivo, 2010. Disponível em:

<http://www.nossasaopaulo.org.br/portal/arquivos/megacidades.pdf.>. Acesso em: 27 jul. 2010.

OCDE - ORGANIZATION FOR ECONOMIC COOPERATION AND DEVELOPMENT. Organization for economic cooperation and development: core set of indicators for environmental performance reviews; a synthesis report by the group on the state of the environment. Paris: OCDE, 1993.

OECD - ORGANIZATION FOR ECONOMIC COOPERATION AND DEVELOPMENT Organisation for Economic Co-operation and Development 2005. Annual Report on Sustainable Development Work in the OECD. 2006. Sustainable Development Studies. Disponível em: <http://www.oecd.org>. Acesso em: 10 maio 2008. 
OMS - Organização Mundial da Saúde. The World Health Report 2007 - A safer future: global public health security in the $21^{\text {st }}$. century. Disponivel em: <http://www.who.int/whr/2007/en/index.html>. Acesso em: 3 set 2010.

OPS - Organización Panamericana de la Salud. Informe regional sobre la evaluación de los servicios de manejo de residuos sólidos en la Región de América Latina y el Caribe. Washington, D.C: OPS, 2005.

OPS - Organización Panamericana de la Salud. Determinantes ambientales y sociales de la salud. Washington, D.C: OPS, 2010.

OTT, W. R. Environmental indices; theory and practice. Michigan: Ann Arbor, 1998.

PACHECO, M. S.; RIBEIRO, H. Grupos de catadores autônomos na coleta seletiva do município de São Paulo. Cadernos metrópole, São Paulo: PUC, v. 21, p. 261-279, 1。sem. 2009.

PADILHA, M. L. Indicadores de desenvolvimento sustentável para o setor têxtil. 2009. 312 p. Tese (Doutorado em Saúde Pública)-Faculdade de Saúde Pública, Universidade de São Paulo, São Paulo.

PILL, J. J. The Delphi Method: Substance, Context, a critique and an Annotated Bibliography. Socio-Economic Planning Sciences, Amsterdam: Elsevier, v.5, p. 57-71, fev. 1971.

PINTÉR, L.; HARDI, P.; BARTELMUS, P. Indicators of Sustainable Development: Proposals for a Way Forward. Discussion Paper prepared under a Consulting Agreement on behalf of the UN Division for Sustainable Development, 2005.

POLAZ, C. N. M. Indicadores de sustentabilidade para gestão de resíduos sólidos urbanos. São Carlos: UFSCar, 2008. 188 p. Dissertação (Mestrado em Engenharia Urbana) - Universidade Federal de São Carlos, 2008.

POST, J. The problems and potentials of privatizing solid waste management in Kumasi, Ghana. Habitat International, Amsterdam: Elsevier, v. 23, p. 201-16, 1999.

REES, W. E.; WACKERNAGEL, M. Our Ecological Footprint: Reducing Human Impact on the Earth. British Columbia: New Society Publishers, 1996.

RIBEIRO, H.; BESEN, G. R.; GÜNTHER, W. M. R.; JACOBI, P. R.; DEMAJOROVIC, J. Recycling programs in partnership with scavenger 
associations as a sustainability factor in metropolitan São Paulo.. In: BREBBIA, C. A.; TIEZZI, E. (Org.). The Sustainable City IV. Southamptom: Wit Press, 1a ed, v. único, p. 409-418, 2006.

RIBEIRO, H.; BESEN, G. R. Panorama da coleta seletiva no Brasil: desafios e perspectivas a partir de três estudos de caso. InterfacEHS, São Paulo: SENAC, v. 2, p.1-6, 2007.

RIBEIRO, H.; JACOBI, P. R.; BESEN, G. R.; GÜNTHER, W. M. R; DEMAJOROVIC, J.; VIVEIROS M. Coleta seletiva com inclusão social: cooperativismo e sustentabilidade. São Paulo: Annablume, 2009.

RIBEIRO, $\mathrm{H}$. et al. Programas municipais de coleta seletiva de lixo como fator de sustentabilidade dos sistemas públicos de saneamento ambiental na região metropolitana de São Paulo - Coselix. In: Brasil. Fundação Nacional de Saúde. 4ํㅡㄹ Caderno de pesquisa em engenharia de saúde pública. Brasília: FUNASA, p. 7-34, 2010.

RODRIGUEZ, C. À procura de alternativas econômicas em tempos de globalização: o caso das cooperativas de recicladores de lixo da Colômbia. In; SANTOS, B. S. (Org.). Produzir para viver- os caminhos da produção não capitalista. Rio de Janeiro: Civilização Brasileira, p.331-364, 2002.

RONDINELLI, D. A.; IACONO, M. Strategic management of privatization: a framework for planning and implementation. Public Administration and Development, v. 16 p. 247-63, 1996.

SAMSON, M. Privatizing collective public goods: refracturing the 'public and resegmenting labour markets. A case study of street cleaning in Johannesburg, South Africa. Studies in Political Economy, Canada: v. 79, p. 119-143, 2007.

SANTOS, C. T. C.; CÂMARA, J. B. D. Perspectivas do meio ambiente no Brasil: GEO BRASIL 2002. BRASÍLIA: IBAMA, 2002.

SCHEINBERG, A.; ANSCHÜTTZ, J.; KLUNDERT, A. Waste Pickers: Poor Victims or Waste Management Professionals? Paper 56. In: Solid waste, health and the Millennium Development Goals. CWG - Wash Workshop 2006, 1 - 5 February, Kolkata, India, 2006.

SCHERER-WARREN, I. Redes de Movimentos. São Paulo: Edições Loyola, 1993. 
SCHÜBELER, P. A. Conceptual Framework for Municipal Solid Waste Management in Lowincome countries. UMP Working Paper, Series 9, Geneva: UMP/SDC SKAT, 1996.

SECRETARIA DE ESTADO DE MEIO AMBIENTE DE SÃO PAULO. Coordenadoria de Planejamento Ambiental. Resíduos Sólidos. Indicadores. Disponível em: <http://www.ambiente.sp.gov.br/cpla/resisol_indicadores.php>. Acesso em: 30 ago. 2010.

SEN, A. K. Desenvolvimento como liberdade. São Paulo: Companhia das Letras, 2000.

SICHE, R.; AGOSTINHO, F.; ORTEGA, E.; ROMEIRO, A. Índices versus indicadores: precisões conceituais na discussão da sustentabilidade de países. Ambiente \& Sociedade. Campinas: v.10, n.2, p.137-148, jul./dez., 2007.

SINGER, P. A recente ressurreição da economia solidária no Brasil. In: Santos $B$ de $S$. organizador. Produzir para viver: os caminhos da produção não capitalista. Rio de Janeiro: Civilização Brasileira, p. 81-126, 2002.

SINGER, P; SOUZA, A. A Economia Solidária no Brasil. São Paulo: Contexto, 2000.

SNIS - Sistema Nacional de Informações sobre Saneamento. Programa de modernização do setor de saneamento: Diagnóstico da gestão e manejo de resíduos sólidos urbanos- 2005. Brasília: MCIDADES/SNSA; 2007.

SNIS - Sistema Nacional de Informações sobre Saneamento. Programa de modernização do setor de saneamento: Diagnóstico da gestão e manejo de resíduos sólidos urbanos- 2008. Brasília: MCIDADES/SNSA; 2010.

SOUZA, A.; LAMOUNIER, B. O futuro da democracia: cenários políticoinstitucionais até 2022. Estud. Av. São Paulo: IEA, v. 20, n. 56, jan. /abr., 2006.

STIGLITZ, J.; SEN, A. K.; FITOUSSI, J. P. Commission on the Measurement of Economic Performance and Social Progress. 2009. Disponível em:

$<$ http://www.stiglitz-sen-fitoussi.fr/documents/rapport_anglais.pdf>. Acesso em: 27 jul. 2010.

SUSTAINABLE SEATTLE. Indicators of sustainable community: a status report on long term cultural, economic and environmental health of Seattle/King County. Seattle, 1998. 
TAYRA, F.; RIBEIRO, H. Modelos de Indicadores de Sustentabilidade: síntese e avaliação crítica. Saúde e Sociedade. São Paulo: v 15, n. 1, p. 84-95, jan./abr., 2006.

TCHOBANOUGLOS, G.; THEISEN, H.; VIGIL, S. Integrated Solid Waste Management Engineering Principles and Management Issues. USA: Mc Grew-Hill, 1993.

TELLUS INSTITUTE, 2008. Assessment of Materials Management Options for the Massachussets Solid Waste Master Plane Review. Final Report, 2010.

TYLER NORRIS ASSOCIATES, REDEFINING PROGRESS \& SUSTAINABLE SEATTLE. The community indicators handbook: measuring progress towards healthy and sustainable communities. Seattle: Redefining Progress, 1997.

UNEP/UN-DESA. Making the Marrakech process work - discussion paper 2nd International expert meeting on the 10-year framework of programmes on sustainable consumption and production. San José, Costa Rica, 5-8 september 2005. Disponível em:

<www.uneptie.org/pc/sustain/10year/regional.htm>. Acesso em: 1dez. 2008.

VEIGA, J. E. Desenvolvimento Sustentável; o desafio do século XXI. Rio de Janeiro: Garamond, 2005.

VEIGA, J. E. Indicadores socioambientais: evolução e perspectivas. Rev. Econ. Polit. São Paulo: v.29, n. 4, out./dez.2009.

VEIGA, J. E. Indicadores de sustentabilidade. Dossiê Teorias Socioambientais. Estud. Av. São Paulo: IEA, v 24, № 68, 2010.

VIEIRA, A. J. N. L.; PINHEL, J. R. Análise evolutiva do programa municipal de coleta seletiva "Lixo da gente - reciclando cidadania" de Santana de Parnaíba SP. In: III ENCONTRO DE FORMADORES E APOIADORES DE EMPREENDIMENTOS DE CATADORES - III ENFAC. São Carlos, 28 de novembro de 2009.

VIVEIROS, M. Coleta Seletiva Solidária: desafios no caminho da retórica à prática sustentável. 2006. 154 p. Dissertação (Mestrado em Ciência Ambiental) - Programa de Ciência Ambiental, Universidade de São Paulo, São Paulo. 
WARREN, J. L. How do we know what is sustainable? A retrospective and prospective view. In: MUSCHETT, F. D. (Ed.). Principles of sustainable development. Flórida: St Lucie Press, p. 131-149, 1997.

WBCSD - WORLD BUSINESS COUNCIL FOR SUSTAINABLE DEVELOPMENT - Vision 2050. Geneva, Switzerland, 2010. Disponível em: <http://www.wbcsd.org/web/projects/BZrole/Vision2050-FullReport_Final.pdf>. Acesso em: 15 out. 2010.

WIEGO - Women in Informal Employment: Globalizing and Organizing. SAMSON, M. (Ed.). Refusing to be Cast Aside: Waste Pickers Organizing Around the World. Cambridge, MA, USA; WIEGO, 2009.

WRIGHT, J.; GIOVINAZZO, R. Delphi - Uma ferramenta de apoio ao planejamento prospectivo. Caderno de Pesquisas em Administração, São Paulo: FIA/FEA/USP, v. 01, n.12, p. 54-65, 2o trimestre 2000.

WWF - Fundo Mundial para a Natureza. Relatório Planeta Vivo 2010: Biodiversidade, biocapacidade e desenvolvimento. BARLOW et al. (Cord.). Brasília, 2010.

XARXA DE CIUTATS. Sistema municipal d'indicadors de sostenibilitat. Diputació de Barcelona: Winihard Gràfics, 2000. 


\section{APÊNDICES}




\section{APÊNDICE A}

\section{TERMO DE CONSENTIMENTO LIVRE E ESCLARECIDO}

Título do Projeto: Avaliação da sustentabilidade dos programas municipais de coleta seletiva.

\section{Pesquisador Responsável: Gina Rizpah Besen}

Esta pesquisa faz parte de uma tese de doutorado da Faculdade de Saúde Pública (área de Saúde Ambiental) da Universidade de São Paulo. O Termo de Consentimento Livre e Esclarecido se refere às entrevistas realizadas pessoalmente ou por e-mail com técnicos municipais, especialistas, pesquisadores e catadores de materiais recicláveis.

\section{Informações sobre a Pesquisa:}

A pesquisa pretende identificar e validar indicadores de sustentabilidade que permitam avaliar os programas municipais de coleta seletiva e as organizações de catadores. Esses indicadores podem auxiliar as prefeituras, organizações de catadores, organizações não governamentais, os órgãos federais e estaduais e de financiamento a avaliar e monitorar os programas de coleta seletiva na busca de sua melhoria ambiental, social e econômica e de sua eficiência. Pretende-se que ela possa contribuir com as políticas públicas de resíduos sólidos e, em especial, com a consolidação dos programas de coleta seletiva e com as organizações de catadores no aprimoramento de seu processo de gestão.

Os dados serão coletados por meio de oficinas e questionários aplicados pela pesquisadora pessoalmente ou via e-mail. Participarão da pesquisa, técnicos municipais que atuam ou já atuaram na gestão de programas de coleta seletiva, lideranças de catadores organizados em associações e cooperativas, membros 
de organizações não governamentais que apóiam as organizações de catadores, e pesquisadores.

Cada participante da pesquisa receberá um questionário para avaliar definições de sustentabilidade, indicadores e suas gradações.

\section{É assegurado aos participantes:}

- A informação sobre os objetivos e resultados do estudo;

- A liberdade para retirar seu consentimento, desde que se manifeste até o fim da entrevista;

- A total confidencialidade, sigilo e privacidade dos dados, sendo que não serão divulgados nomes e as informações prestadas serão utilizadas somente para os propósitos da pesquisa.

- Procurar esclarecimentos com o Comitê de Ética em Pesquisa da Faculdade de Saúde Pública da Universidade de São Paulo, no telefone 11 3061-7779 ou Av. Dr. Arnaldo, 715 - Cerqueira César, São Paulo - SP, em caso de dúvidas ou notificação de acontecimentos não previstos.

Declaro estar ciente do exposto e desejar participar da pesquisa.

São Paulo, de de

Nome do

sujeito/

ou

do responsável:

Assinatura:

Eu, Gina Rizpah Besen, declaro que forneci todas as informações referentes ao projeto ao participante e/ou responsável.

Assinatura:

Data:

Telefone: 11 3672-92-79. Responsável:- Orientadora/Supevisora: Helena Ribeiro - fone: 30617739. 


\section{APÊNDICE B}

\section{Questionário da 1ª rodada técnica Delphi}

Tese de Doutorado: Avaliação da sustentabilidade de programas municipais de coleta seletiva

Responsável: Gina Rizpah Besen

Dados do entrevistado:

Profissão:

Cidade:

Sexo: Idade:

Atividade atual:

Escolaridade:

Há quanto tempo trabalha com o tema:

\section{Informações sobre o Questionário}

Você está recebendo um questionário que pretende avaliar:

1- Duas definições de sustentabilidade, uma de programas municipais de coleta seletiva e uma de organizações de catadores de materiais recicláveis.

2- Dois grupos de indicadores de sustentabilidade, o primeiro de programas municipais de coleta seletiva e o segundo de organizações de catadores e suas respectivas gradações.

\section{Instruções de preenchimento}

Ítem 1- Assinale com um $X$ as respostas às questões 1 e 2 . Se a resposta foi concordo parcialmente ou discordo justifique nas linhas abaixo da questão.

Item 2- Assinale com um " $X$ " as respostas às questões 3 e 4 na tabela 1. Dê a nota que cada indicador merece, de acordo com o grau de importância que você atribui a ele para a questão que ele mede.

0
Menos importante

No caso do primeiro grupo de indicadores, se pretende avaliar quais destes são considerados mais importantes quando se avalia a sustentabilidade 
de um programa de coleta seletiva. No caso do segundo grupo de indicadores, se pretende avaliar quais destes são mais importantes quando se avalia a sustentabilidade de uma organização de catadores.

No final de cada tabela dos grupos de indicadores existem algumas linhas em branco para que você possa sugerir indicadores que não estão listados, mas que você considera importante. Também atribua uma nota aos indicadores que você sugeriu e explique porque os selecionou nas observações.

Ítem 3- Assinale com um $X$ as respostas às questões 5 e 6 referentes às gradações dos indicadores. Se concordar com todas as gradações de um mesmo indicador assinale concordo, se discordar de qualquer uma das gradações propostas para um mesmo indicador assinale concordo parcialmente e se não concordar com nenhuma gradação do indicador assinale discordo. As gradações servem para calibrar os indicadores e definir se o que se quer medir está mais próximo ou mais distante da sustentabilidade. Se você propôs algum indicador novo procure verificar se é possível também propor a sua gradação.

Exemplo

\begin{tabular}{|c|c|c|c|c|c|c|}
\hline & \multicolumn{3}{|c|}{ Gradação } & \multicolumn{3}{c|}{ Avaliação } \\
\hline Indicador & + & - & $+/-$ & Concordo & $\begin{array}{c}\text { Concordo } \\
\text { parcialmente }\end{array}$ & Discordo \\
\hline $\begin{array}{l}\text { 1.Sustentabili- } \\
\text { dade econômica }\end{array}$ & $\begin{array}{c}\text { Existência } \\
\text { de taxa } \\
\text { específica }\end{array}$ & $\begin{array}{c}\text { Não } \\
\text { existência } \\
\text { de } \\
\text { cobrança }\end{array}$ & $\begin{array}{c}\text { Cobrança } \\
\text { de taxa no } \\
\text { IPTU }\end{array}$ & & X & \\
\hline
\end{tabular}

Exemplo de justificativa: concordo parcialmente que a cobrança da taxa no IPTU seja +/-. Acho que é + porque sou contra a cobrança de taxa específica. 
O processo de validação de indicadores requer mais de uma rodada de questionários para chegar num consenso. Após a obtenção dos resultados da primeira rodada você receberá um novo questionário.

Agradecemos desde já a sua participação nessa pesquisa e reiteramos a importância de sua contribuição para que possamos identificar e validar indicadores de sustentabilidade que contribuam com a coleta seletiva e que sejam utilizados tanto pelas prefeituras quanto pelas organizações de catadores.

\section{QUESTIONÁRIO}

\section{Questão 1 - Assinale com um $X$ as respostas às questões 1 e 2}

Sustentabilidade de um programa de coleta seletiva é a capacidade deste desenvolver suas atividades com garantia legal e de recursos e com a meta de universalização dos serviços e obtenção de resultados ambientais e sociais crescentes.

concordo

concordo parcialmente discordo

Se a resposta foi concordo parcialmente ou discordo, explique:

\section{Questão 2}

Sustentabilidade de uma organização de catadores é a capacidade desta desenvolver suas atividades, com a garantia de regularização institucional e a geração de trabalho e renda em condições adequadas aos membros da organização.

Concordo concordo parcialmente discordo

Se a resposta foi concordo parcialmente ou discordo, explique: 
Questão 3 - Assinale com um X o grau de importância que você dá a cada um dos indicadores de sustentabilidade de programas municipais de coleta seletiva propostos na tabela abaixo:

\begin{tabular}{|l|l|l|l|l|l|l|l|l|l|l|l|}
\hline & \multicolumn{9}{|c|}{ Avaliação } \\
\hline Indicadores & $\mathbf{0}$ & $\mathbf{1}$ & $\mathbf{2}$ & $\mathbf{3}$ & $\mathbf{4}$ & $\mathbf{5}$ & $\mathbf{6}$ & $\mathbf{7}$ & $\mathbf{8}$ & $\mathbf{9}$ & $\mathbf{1 0}$ \\
\hline 1. Sustentabilidade econômica & & & & & & & & & & & \\
\hline 2. Marco legal & & & & & & & & & & & \\
\hline 3. Parcerias da coleta seletiva & & & & & & & & & & & \\
\hline 4. Cobertura da coleta & & & & & & & & & & & \\
\hline $\begin{array}{l}\text { 5.Taxa de recuperação de recicláveis } \\
\text {-TRMR }\end{array}$ & & & & & & & & & & & \\
\hline 6.Taxa de rejeito-TR** & & & & & & & & & & & \\
\hline 7. & & & & & & & & & & & \\
\hline 8. & & & & & & & & & & & \\
\hline 9. & & & & & & & & & & & \\
\hline
\end{tabular}

*TRMR $(\%)$ = Quantidade da coleta seletiva - quantidade de rejeitos da triagem $\times 100$

Quantidade coletada seletivamente + quantidade coleta regular

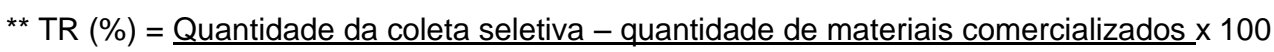

Observações: Quantidade da coleta seletiva

Questão 4- Assinale com um X o grau de importância que você dá a cada um dos indicadores de sustentabilidade de organizações de catadores propostos:

\begin{tabular}{|c|c|c|c|c|c|c|c|c|c|c|}
\hline \multirow[t]{2}{*}{ Indicadores } & \multicolumn{10}{|c|}{ Avaliação } \\
\hline & 1 & 2 & 3 & 4 & 5 & 6 & 7 & 8 & S & 10 \\
\hline 1. Regularizac & & & & & & & & & & \\
\hline 2. Instrumentc & & & & & & & & & & \\
\hline 3. Rotatividad & & & & & & & & & & \\
\hline 4. Capacitaçã & & & & & & & & & & \\
\hline 5. Renda men & & & & & & & & & & \\
\hline 6. Participaçã & & & & & & & & & & \\
\hline 7. Condição d & & & & & & & & & & \\
\hline 8. Equipamen & & & & & & & & & & \\
\hline 9. Horas traba & & & & & & & & & & \\
\hline 10. Benefícios & & & & & & & & & & \\
\hline $\begin{array}{l}\text { 11. Uso de Eq } \\
\text { Individual }\end{array}$ & & & & & & & & & & \\
\hline 12. Parcerias & & & & & & & & & & \\
\hline 13. & & & & & & & & & & \\
\hline 14. & & & & & & & & & & \\
\hline 15. & & & & & & & & & & \\
\hline
\end{tabular}


Questão 5 - Assinale com um X a sua opinião sobre as gradações dos indicadores e índices dos programas de coleta seletiva propostos na tabela abaixo:

\begin{tabular}{|c|c|c|c|c|c|c|}
\hline \multicolumn{7}{|c|}{ Indicadores } \\
\hline & \multicolumn{3}{|c|}{ Gradações } & \multicolumn{3}{|c|}{ Avaliação } \\
\hline & + & - & $+/-$ & $\mathrm{C}$ & $\mathrm{CP}$ & D \\
\hline $\begin{array}{l}\text { 1. Sustentabilidade } \\
\text { econômica }\end{array}$ & $\begin{array}{l}\text { Existência de } \\
\text { taxa específica }\end{array}$ & $\begin{array}{l}\text { Não } \\
\text { existência }\end{array}$ & $\begin{array}{l}\text { Cobrança de } \\
\text { taxa no IPTU }\end{array}$ & & & \\
\hline 2. Marco legal & $\begin{array}{l}\text { Com lei e } \\
\text { convênio }\end{array}$ & $\begin{array}{l}\text { Sem lei nem } \\
\text { convênio }\end{array}$ & $\begin{array}{l}\text { Só lei ou só } \\
\text { convênio }\end{array}$ & & & \\
\hline 3. Parcerias & Duas ou mais & Nenhuma & Uma & & & \\
\hline 4. Cobertura da coleta & $75 \%$ a $100 \%$ & $<30 \%$ & $31 \%$ a74, $9 \%$ & & & \\
\hline $\begin{array}{l}\text { 5. Taxa de recuperação } \\
\text { de recicláveis * }\end{array}$ & $\begin{array}{l}\text { Alta } \\
>11 \%\end{array}$ & $\begin{array}{l}\text { Baixa } \\
\text { até } 5 \%\end{array}$ & $\begin{array}{l}\text { Média } \\
5,1 \% \text { a } 10 \%\end{array}$ & & & \\
\hline 6. Taxa de rejeito** & $\begin{array}{l}\text { Baixa } \\
\text { até } 7 \%\end{array}$ & $\begin{array}{l}\text { Alta } \\
>21 \%\end{array}$ & $\begin{array}{l}\text { Média } \\
5,1 \% \text { a } 20 \%\end{array}$ & & & \\
\hline \multicolumn{7}{|l|}{7.} \\
\hline \multicolumn{7}{|l|}{8.} \\
\hline 9. & & & & & & \\
\hline
\end{tabular}

C- concordo CP - concordo parcialmente D- discordo

${ }^{*} \operatorname{TRMR}(\%)=\underline{\text { Quantidade da coleta seletiva }- \text { quantidade de rejeitos da triagem }} \times 100$

Quantidade coletada seletivamente + quantidade coleta regular

** $\operatorname{TR}(\%)=\underline{\text { Quantidade da coleta seletiva }- \text { quantidade de materiais comercializados }} \times 100$ Quantidade da coleta seletiva

Questão 6 - Assinale com um X a sua opinião sobre as gradações dos indicadores das organizações de catadores propostos na tabela abaixo:

Se você concordou parcialmente ou discordou de alguma das gradações, explique: 


\begin{tabular}{|c|c|c|c|c|c|c|}
\hline \multirow[t]{2}{*}{ Indicador } & \multicolumn{3}{|c|}{ Gradações } & \multicolumn{3}{|c|}{ Avaliação } \\
\hline & + & - & $+/-$ & C & $\mathrm{CP}$ & $\mathrm{D}$ \\
\hline $\begin{array}{l}\text { 1. Regularização da } \\
\text { organização }\end{array}$ & Regularizada & $\begin{array}{l}\text { Não } \\
\text { regularizada }\end{array}$ & ------ & & & \\
\hline $\begin{array}{l}\text { 2. Instrumento legal de } \\
\text { parceria }\end{array}$ & $\begin{array}{l}\text { Cooperativa c/ } \\
\text { convênio ou OSCIP } \\
\text { c/ contrato }\end{array}$ & Não possui & $\begin{array}{l}\text { Associação } \\
\text { com convênio }\end{array}$ & & & \\
\hline 3. Rotatividade anual & $\begin{array}{l}\text { Até } 25 \% \text { dos } \\
\text { membros }\end{array}$ & Mais de $50 \%$ & $\begin{array}{l}\text { Entre } 25 \text { e } \\
50 \%\end{array}$ & & & \\
\hline $\begin{array}{l}\text { 4. Capacitação dos } \\
\text { membros }\end{array}$ & Incubada* & Não capacitada & Capacitada & & & \\
\hline $\begin{array}{l}\text { 5. Renda mensal por } \\
\text { membro }\end{array}$ & $\begin{array}{l}\text { Dois salários } \\
\text { mínimos }\end{array}$ & $\begin{array}{l}\text { Um salário } \\
\text { mínimo }\end{array}$ & $\begin{array}{l}\text { Entre um e } \\
\text { dois }\end{array}$ & & & \\
\hline $\begin{array}{l}\text { 6. Participação dos } \\
\text { membros }^{\star *}\end{array}$ & Alta & Baixa & Média & & & \\
\hline $\begin{array}{l}\text { 7. Condição da } \\
\text { instalação }\end{array}$ & Própria & Cedida & Alugada & & & \\
\hline $\begin{array}{l}\text { 8. Equipamentos/ } \\
\text { veículos }\end{array}$ & Próprios & Cedidos & $\begin{array}{l}\text { Próprios/cedi } \\
\text { dos* }^{*}\end{array}$ & & & \\
\hline $\begin{array}{l}\text { 9. Horas trabalhadas } \\
\text { dia/membro }\end{array}$ & Mais de 6 & Até 4 & Entre 4 e 6 & & & \\
\hline $\begin{array}{l}\text { 10. Benefícios para os } \\
\text { membros }\end{array}$ & 3 ou mais & Nenhum & Um ou dois & & & \\
\hline 11. EPIs & Usam EPIs & Não possuem & Não usam & & & \\
\hline $\begin{array}{l}\text { 12. № de parcerias das } \\
\text { organizações }\end{array}$ & Duas ou mais & uma & Nenhuma & & & \\
\hline \multicolumn{7}{|l|}{13.} \\
\hline \multicolumn{7}{|l|}{14.} \\
\hline 15. & & & & & & \\
\hline
\end{tabular}

*Incubada - que recebeu capacitação anterior ao início do funcionamento

${ }^{* *}$ Alta - entre $75 \%$ e $100 \%$ dos membros Média - entre $30 \%$ e $75 \%$ dos membros -Baixa entre 30 e $50 \%$

C- concorda $\quad$ CP - concorda parcialmente D - discorda.

\section{Observações}




\section{APÊNDICE C}

\section{Convite da oficina regional de São Paulo}

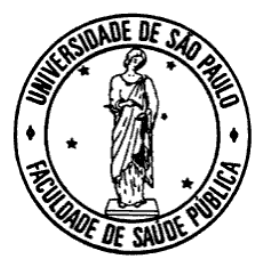

\section{UNIVERSIDADE DE SÃO PAULO FACULDADE DE SAÚDE PÚBLICA CONVITE}

No ano de 2005 foi desenvolvida a pesquisa "Programas Municipais de Coleta Seletiva em Parceria com Cooperativas de Catadores na Região Metropolitana de São Paulo, como Fator de Sustentabilidade dos Sistemas de Limpeza Pública". A pesquisa foi coordenada pela Faculdade de Saúde Pública, desenvolvida em parceria com o PROCAM/USP e a gestão ambiental do SENAC e financiada pela FUNASA.

Os programas municipais de coleta seletiva em parceria com organizações de catadores vêm se multiplicando pelo país e se tornando modelo de política pública de resíduos sólidos, pois permitem a minimização de resíduos, com inclusão social e geração de renda. A pesquisa identificou e caracterizou os programas da Região Metropolitana de São Paulo, avaliou seus resultados em termos de sustentabilidade econômica, social e ambiental e desenvolveu indicadores de sustentabilidade para os programas e para as organizações de catadores.

Convidamos os principais atores envolvidos com esta temática; representantes de organizações de catadores, Fóruns Lixo e Cidadania e técnicos de órgãos públicos municipais e estaduais para conhecer e discutir os indicadores de sustentabilidade desenvolvidos. Os resultados deste encontro 
serão incorporados ao processo de discussão e de validação destes indicadores no âmbito da Tese de Doutorado desenvolvida por Gina Rizpah Besen na FSP/USP - área de Saúde Ambiental.

Data: 3 de setembro de 2007. Horário: 14:30 hs às 18:00 hs.

Local: Sede da ABES. Associação de Engenharia Sanitária e Ambiental

Rua Costa Carvalho.

Realização: Faculdade de Saúde Pública e Fórum Lixo e Cidadania do Estado de São Paulo. 


\section{APÊNDICE D}

\section{Convite da oficina regional de Belo Horizonte}

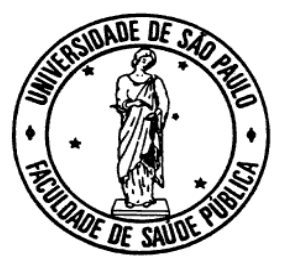

\section{UNIVERSIDADE DE SÃO PAULO \\ FACULDADE DE SAÚDE PÚBLICA \\ CONVITE}

No ano de 2005 foi desenvolvida a pesquisa "Programas Municipais de Coleta Seletiva em Parceria com Cooperativas de Catadores na Região Metropolitana de São Paulo, como Fator de Sustentabilidade dos Sistemas de Limpeza Pública". A pesquisa foi coordenada pela Faculdade de Saúde Pública, desenvolvida em parceria com o PROCAM/USP e a gestão ambiental do SENAC e financiada pela FUNASA.

Os programas municipais de coleta seletiva em parceria com organizações de catadores vêm se multiplicando pelo país e se tornando modelo de política pública de resíduos sólidos, pois permitem a minimização de resíduos, com inclusão social e geração de renda. A pesquisa identificou e caracterizou os programas da Região Metropolitana de São Paulo, avaliou seus resultados em termos de sustentabilidade econômica, social e ambiental e desenvolveu indicadores de sustentabilidade para os programas e para as organizações de catadores.

Convidamos os principais atores envolvidos com esta temática; representantes de organizações de catadores, Fóruns Lixo e Cidadania e técnicos de órgãos públicos municipais e estaduais para conhecer e discutir os indicadores de sustentabilidade desenvolvidos. Os resultados deste encontro 
serão incorporados ao processo de discussão e de validação destes indicadores no âmbito da Tese de Doutorado desenvolvida por Gina Rizpah Besen na FSP/USP - área de Saúde Ambiental.

Data: 03 de setembro de 2007. Horário: 14:30hs às 18:00hs

Local: Fundação Centro Tecnológico de Minas Gerais - CETEC. Avenida José Cândido da Silveira 2000. Cidade Nova. Sala 07. Fone: 34892383 (SAT). Realização: Faculdade de Saúde Pública - Universidade de São Paulo Apoio: Fundação Centro Tecnológico de Minas Gerais - CETEC. 


\section{APÊNDICE E}

\section{Convite da oficina regional do Rio de Janeiro}

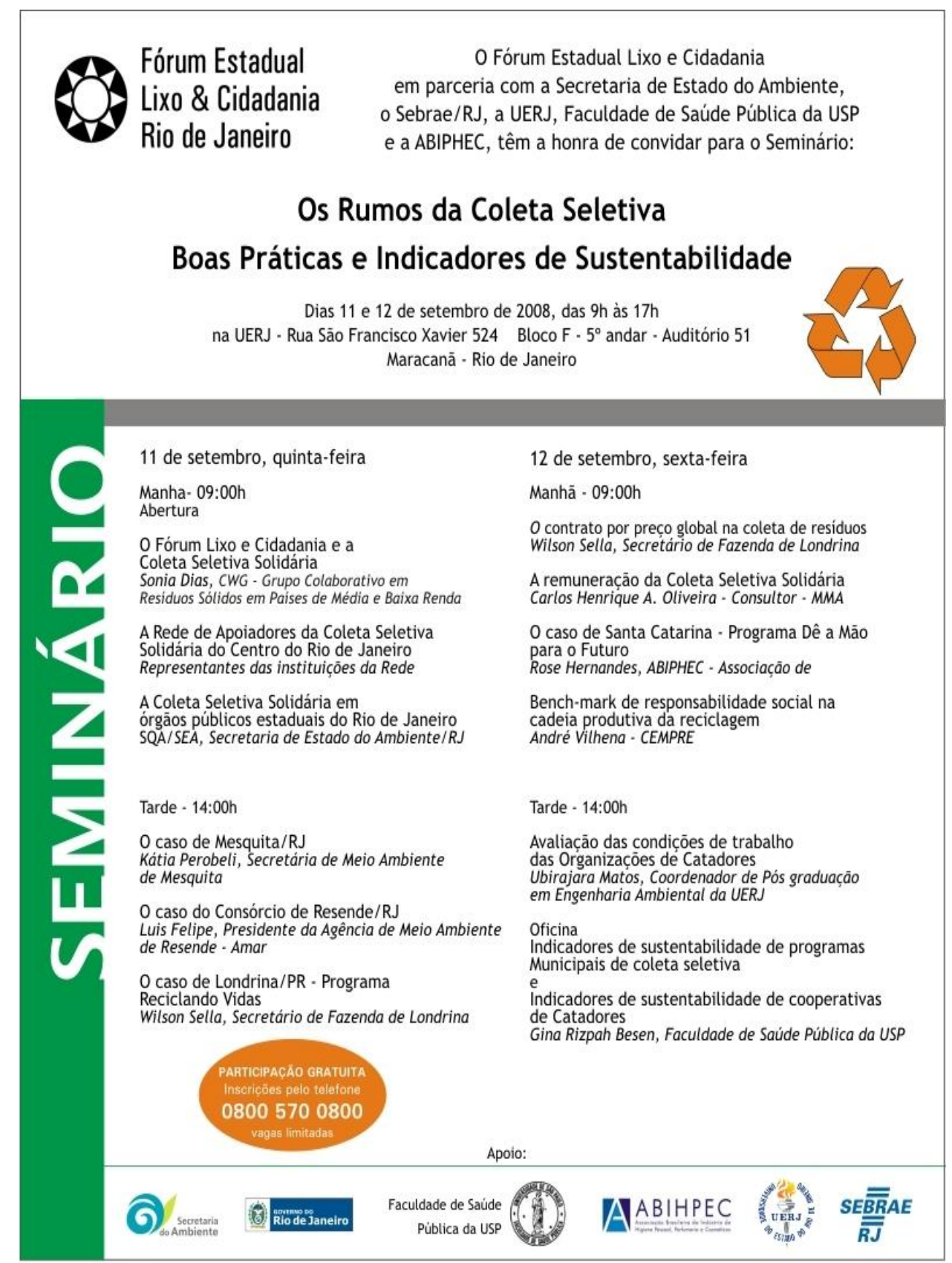

ABIPHEC 


\title{
APÊNDICE F
}

\section{Convite da oficina regional de Recife}

\section{ENCONTRO DO FÓRUM LIXO E CIDADANIA DE PERNAMBUCO - FLIC -PE}

\author{
PROGRAMA
}

9h - Abertura e Informes Gerais do FLIC-PE

$10 \mathrm{~h}$ - Palestra "Desafios Atuais dos Programas de Coleta Seletiva no Brasil" Gina Rizpah Besen (São Paulo/SP).

11h - Debates

$12 \mathrm{~h}$ - Almoço

13h - Oficina de Trabalho sobre os Indicadores de Sustentabilidade - Gina Rizpah Besen / Universidade de São Paulo - Faculdade de Saúde Pública.

17h - Encerramento

Local: Conselho Regional de Engenharia CREA - Recife

Data: 27 de novembro de 2008

Realização: Fórum Lixo e Cidadania de Pernambuco

Apoio: Faculdade de Saúde Pública da Universidade de São Paulo. 


\section{APÊNDICE G}

\section{Questionário da 2ª rodada técnica Delphi}

\section{Faculdade de Saúde Pública da Universidade de São Paulo}

Questionário da $2^{\mathrm{a}}$ rodada técnica Delphi com especialistas

Tese: Avaliação da sustentabilidade de programas municipais de coleta seletiva Responsável: Gina Rizpah Besen Orientadora; Profa. Helena Ribeiro

\section{Entrevistado:}

\section{Informações sobre o Questionário}

Agradeço sua participação na primeira rodada de questionários e as contribuições. Esta é a segunda rodada de aplicação de questionários da pesquisa. Segue anexo um relatório com os resultados da primeira rodada. Do total enviado, obteve-se um índice de resposta de $52,6 \%$, o que equivale a 59 questionários retornados. Isso revela o interesse despertado pela pesquisa. Nessa segunda rodada buscou-se incorporar ao máximo as contribuições dos participantes e esclarecer melhor alguns indicadores. Os novos indicadores e respectivas gradações foram propostos pelos participantes, e em 4 oficinas realizadas pela pesquisadora, com atores sociais envolvidos com o tema nas cidades de: São Paulo, Belo Horizonte, Rio de Janeiro e Recife, e agregados nessa $2^{2}$ rodada para serem avaliados.

Pretende-se chegar ao maior nível de consenso possível. Ressalto ainda que os indicadores propostos visam à melhoria da gestão dos programas e das organizações, por meio do estabelecimento de metas de 
sustentabilidade que possam ser monitoradas e alcançadas gradualmente.

Agora vocês que nos responderam estão recebendo um novo questionário que pretende avaliar:

1) Quatro definições de sustentabilidade, duas sobre programas municipais de coleta seletiva e duas sobre organizações de catadores de materiais recicláveis e 2) Dois grupos de indicadores de sustentabilidade, o primeiro sobre programas municipais de coleta seletiva e o segundo sobre organizações de catadores e suas respectivas gradações.

Estou à disposição para quaisquer esclarecimentos necessários por email ou pelo fone (11) 36729279/ (11) 8147-6695 


\section{Questionário}

Questão 1 - Assinale com um X a definição de sustentabilidade de um programa de coleta seletiva que considerar mais adequada;

Definição 1 - Sustentabilidade de um programa de coleta seletiva é a capacidade de desenvolver suas atividades com garantia legal e de recursos e com a meta de universalização dos serviços e obtenção de resultados ambientais e sociais crescentes.

Resultado da primeira rodada - $61 \%$ concorda, $37 \%$ concorda parcialmente e $2 \%$ discorda.

Definição 2 - Sustentabilidade de um programa de coleta seletiva é a capacidade de desenvolver suas atividades de forma eficiente, com garantia legal e de recursos técnicos, e a meta de universalização dos serviços e obtenção de resultados ambientais (exemplos: educação ambiental permanente e redução da disposição em lixões e aterros), sociais (exemplos: inclusão social, gestão democrática e participativa) e econômicos (exemplos: recursos de taxa ou do orçamento, geração de renda e ampliação das atividades de beneficiamento) crescentes.

Definição 1

Definição 2

Observações:

Questão 2- Assinale com um $X$ a definição de sustentabilidade de uma organização de catadores que considerar mais adequada: 
Definição 1 - Sustentabilidade de uma organização de catadores é a capacidade desta desenvolver suas atividades, com a garantia de regularização institucional e a geração de trabalho e renda em condições adequadas aos membros da organização.

Primeira rodada - $53 \%$ concorda, $44 \%$ concorda parcialmente e $3 \%$ discorda.

Definição 2- Sustentabilidade de uma organização de catadores é a capacidade desta desenvolver suas atividades, com a garantia de; regularidade institucional, autogestão (administrativa, financeira, organizacional) e a geração de trabalho e renda em condições adequadas de saúde pública e segurança do trabalho aos membros da organização para atingir resultados sociais, econômicos, e ambientais crescentes.

Definição 1

Definição 2

Observações:

Questão 3 - Avalie algumas características dos indicadores dos programas de coleta seletiva segundo a legenda abaixo, assinalando com $X(\operatorname{sim})$ as que considera que o indicador possui:

R- REPRESENTATIVIDADE = Relevância.

C- COMPARABILIDADE = Amplitude geográfica adequada, padronização, e sensibilidade a mudanças no tempo.

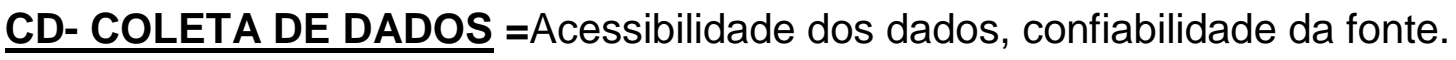


CS- CLAREZA E SÍNTESE = Clareza na comunicação e capacidade de síntese.

PM- PREVISÃO E METAS = Pró-atividade, facilidade para definição de metas, preditividade.

Após a avaliação das características do indicador dê uma nota de 0 a 10 para cada um segundo o grau de importância. Em seguida, avalie o modo de cálculo do indicador, colocando $\mathrm{C}$ se concordar, CP se concordar parcialmente, e D se discordar. Se concordar parcialmente ou discordar justifique 


\begin{tabular}{|c|c|c|c|c|c|c|c|c|}
\hline & \multicolumn{5}{|c|}{$\underline{\text { Características }}$} & \multirow[b]{2}{*}{ Nota } & \multirow[b]{2}{*}{ MODO DE MEDIÇÃO } & \multirow[b]{2}{*}{$\begin{array}{l}\text { Ava- } \\
\text { lia- } \\
\text { ção }\end{array}$} \\
\hline INDICADORES e ÍNDICES & $\mathrm{R}$ & C & CD & CS & PM & & & \\
\hline $\begin{array}{l}\text { 1- Percentual de atendimento da } \\
\text { população }\end{array}$ & & & & & & & $\begin{array}{l}\text { N. da população atendida pelo programa } \\
\text { N. da população do município }\end{array} \times 100$ & \\
\hline 2- Percentual de adesão da população. & & & & & & & $\frac{N \text {. de residências que participam do programa }}{N \text {. total de residências atendidas pelo programa }} \times 100$ & \\
\hline 3- Percentual de parcerias do Programa & & & & & & & $\frac{N . \text { de parcerias efetivadas }}{N . \text { de parcerias desejáveis }} \times 100$ & \\
\hline 4- Programa de educação e divulgação. & & & & & & & Freqüência anual de atividades desenvolvidas & \\
\hline $\begin{array}{l}\text { 5- Implementação da gestão compartilhada } \\
\text { do programa com a sociedade civil }\end{array}$ & & & & & & & $\begin{array}{l}\text { Existência de canais efetivos de participação da } \\
\text { sociedade civil }{ }^{\star \star}\end{array}$ & \\
\hline $\begin{array}{l}\text { 6- Percentual de inclusão de catadores } \\
\text { avulsos. }\end{array}$ & & & & & & & $\begin{array}{l}\mathrm{N} \text { de catadores avulsos incluídos } \times 100 \\
\mathrm{~N} \text {. de catadores avulsos existentes }\end{array}$ & \\
\hline $\begin{array}{l}\text { 7- Instrumentos legais na relação com as } \\
\text { organizações de catadores }\end{array}$ & & & & & & & $\begin{array}{l}\text { Atendimento aos requisitos legais de } \\
\text { contratação }\end{array}$ & \\
\hline $\begin{array}{l}\text { 8- Percentual de recuperação de materiais } \\
\text { recicláveis em relação ao total coletado* }\end{array}$ & & & & & & & $\begin{array}{l}\text { Q.da coleta seletiva }-Q . \text { de rejeitos } \\
\text { Q. coletada seletiva }+ \text { Q coleta regular }\end{array} \times 100$ & \\
\hline 9- Percentual de rejeito $-\mathrm{TR}^{\star *}$ & & & & & & & $\frac{\text { Q.da coleta seletiva }- \text { Q. comercializada }}{\text { Q.da coleta seletiva }} \times 100$ & \\
\hline $\begin{array}{l}\text { 10- Percentual de adequação das } \\
\text { condições de trabalho na central de } \\
\text { triagem. }\end{array}$ & & & & & & & $\frac{N . \text { de requisitos atendidos }}{N \text { de requisitos desejáveis }} \times 100$ & \\
\hline $\begin{array}{l}\text { 11- Percentual de auto-financiamento do } \\
\text { programa }\end{array}$ & & & & & & & $\frac{\text { Recursos do IPTU e/ou de taxa de lixo }(\mathrm{R} \$)}{\text { Custo do programa }(\mathrm{R} \$)} \times 100$ & \\
\hline $\begin{array}{l}\text { 12- Percentual do custo do programa em } \\
\text { relação ao custo do manejo de resíduos. }\end{array}$ & & & & & & & $\begin{array}{c}\text { Total de despesas da coleta seletiva }(\mathrm{R} \$) \times 100 \\
\text { Total de despesas com os serviços de manejo } \\
\text { de resíduos sólidos }(\mathrm{R} \$)\end{array}$ & \\
\hline $\begin{array}{l}\text { 13- Custo do programa em relação à } \\
\text { quantidade coletada seletivamente. }\end{array}$ & & & & & & & $\begin{array}{l}\text { Custo total do programa }(\mathrm{R} \$) \\
\text { Quantidade da coleta seletiva }\end{array}$ & \\
\hline $\begin{array}{l}\text { 14- Percentual de custo da coleta seletiva } \\
\text { em relação à coleta regular e aterramento }\end{array}$ & & & & & & & $\begin{array}{l}\text { Custo da coleta seletiva }(\mathrm{R} \$ / \mathrm{t}) \\
\text { Custo da coleta regular }+ \text { custo do aterramento } \\
(\mathrm{R} \$ / \mathrm{t})\end{array}$ & \\
\hline
\end{tabular}


Notas: N. número Q-quantidade

${ }^{*}$ TRMR $=$ Quantidade da coleta seletiva - quantidade de rejeitos da triagem $\times 100$

Quantidade coletada seletivamente + quantidade coleta regular

** TR $=\underline{\text { Quantidade da coleta seletiva }- \text { quantidade de materiais comercializados }} \times 100$

Quantidade da coleta seletiva

*Exemplos: Outras organizações de catadores (redes), setor público estadual ou federal, setor privado, organizações não governamentais, entidades representativas dos catadores.

**Exemplos: Comitês Gestores, Fórum Lixo e Cidadania, Câmara Técnicas ou GTs de Resíduos em Conselhos de Meio Ambiente, Fóruns da Agenda 21. Exemplos de efetividade: influencia na formulação das políticas públicas, monitoramento da implementação, articulação de apoios e parcerias.

*** Exemplos: rotina de limpeza, sanitários em condições adequadas de uso, refeitório em boas condições, ausência de vetores de doenças; ratos, moscas e barata, cobertura adequada, ventilação adequada, ausência de odores incômodos, sistema de prevenção de incêndios.

\section{JUSTIFICATIVA:}

Questão 4- Assinale com um $X$ as respostas referentes às gradações dos indicadores dos programas. Se concordar com todas as gradações de um mesmo indicador assinale Concordo; se discordar de qualquer uma das gradações assinale Parcial, e se não concordar com nenhuma assinale Discordo. As gradações servem para calibrar os indicadores e definir se o que se quer medir está mais próximo ou mais distante da sustentabilidade. 


\begin{tabular}{|c|c|c|c|c|c|c|}
\hline \multirow[t]{2}{*}{ Indicador } & \multicolumn{3}{|c|}{ Tendências à sustentabilidade } & \multicolumn{3}{|c|}{ Avaliação } \\
\hline & Alta $(+)$ & Média (+/-) & Baixa (-) & C & $\mathrm{CP}$ & $\mathrm{D}$ \\
\hline $\begin{array}{l}\text { 1- Percentual de atendimento da população com } \\
\text { a coleta seletiva }\end{array}$ & $80 \%$ a $100 \%$ & $40,1 \%$ a $79,9 \%$ & $\leq 40 \%$ & & & \\
\hline 2- Percentual de adesão da população. & $\geq 80 \%$ & $40,1 \%$ a $79,9 \%$ & $\leq 40 \%$ & & & \\
\hline 3- Percentual de Parcerias do Programa & $80 \%$ a $100 \%$ & $50,1 \%$ a $80 \%$ & $\leq 50 \%$ & & & \\
\hline $\begin{array}{l}\text { 4- Freqüência de programa de educação e } \\
\text { divulgação }\end{array}$ & $\begin{array}{c}\text { Permanente } \\
\text { Quinzenal ou Mensal }\end{array}$ & Bi e Trimestral & Anual/pontual & & & \\
\hline $\begin{array}{l}\text { 5- Implementação da gestão compartilhada do } \\
\text { programa com a sociedade civil }\end{array}$ & Existe e funciona & $\begin{array}{l}\text { Existe, mas não } \\
\text { funciona bem }\end{array}$ & Não existe & & & \\
\hline 6- Percentual de inclusão de catadores avulsos. & $80 \%$ a $100 \%$ & $50,1 \%$ a $79,9 \%$ & $\leq 50 \%$ & & & \\
\hline $\begin{array}{l}\text { 7- Implementação de instrumentos legais na } \\
\text { relação com as organizações de catadores }\end{array}$ & $\begin{array}{l}\text { Contrato ou Convenio } \\
\text { com remuneração }\end{array}$ & $\begin{array}{l}\text { Convenio } \\
\text { sem remuneração }\end{array}$ & $\begin{array}{c}\text { Inexistência de } \\
\text { contrato ou } \\
\text { convenio }\end{array}$ & & & \\
\hline $\begin{array}{l}\text { 8- Percentual de recuperação de materiais } \\
\text { recicláveis em relação do total coletado. }\end{array}$ & $\geq 20 \%$ & $10,1 \%$ a $19,9 \%$ & $\leq 10 \%$ & & & \\
\hline 9- Percentual de Rejeito & $\leq 10 \%$ & $10,1 \%$ a $29,9 \%$ & $>30 \%$ & & & \\
\hline $\begin{array}{l}\text { 10- Percentual de adequação das condições de } \\
\text { trabalho na central de triagem. }\end{array}$ & $80 \%$ a $100 \%$ & $50,1 \%$ a $79 \%$ & $\leq 50 \%$ & & & \\
\hline $\begin{array}{l}\text { 11- Percentual de autofinanciamento do } \\
\text { programa. }\end{array}$ & $80 \%$ a $100 \%$ & $50,1 \%$ a $79,9 \%$ & $\leq 50 \%$ & & & \\
\hline $\begin{array}{l}\text { 12- Percentual do custo do programa em } \\
\text { relação ao custo do manejo de resíduos. }\end{array}$ & $\leq 50 \%$ & $50,1 \%$ a $74,9 \%$ & $\geq 75 \%$ & & & \\
\hline $\begin{array}{l}\text { 13. Custo do programa em relação à quantidade } \\
\text { coletada seletivamente * }\end{array}$ & $\leq \mathrm{R} \$ 175,00 / \mathrm{t}$ & $\begin{array}{l}\mathrm{R} \$ 170,1 \text { a } \mathrm{R} \$ \\
350,00\end{array}$ & $\geq \mathrm{R} \$ 350,00 / \mathrm{t}$ & & & \\
\hline $\begin{array}{l}\text { 14- Percentual de custo da coleta seletiva em } \\
\text { relação à coleta regular e aterramento ** }\end{array}$ & $\leq 50 \%$ & $50,1 \%$ a $199,9 \%$ & $\geq 200 \%$ & & & \\
\hline
\end{tabular}

Notas: C- concordo, CP - concordo parcialmente D - discordo 
${ }^{*} \mathrm{O}$ valor de $\mathrm{R} \$ 175,00 / \mathrm{t}$ foi considerado viável e baixo para a coleta seletiva a partir dos seguintes cálculos: $\mathrm{R} \$ 72,00 / t$ é o valor médio para a coleta convencional apurado pelo SNIS 2006 (R\$61,32/t.) e reajustado em 17,5\% (agosto de 2008 pelo IGPm). Considerando-se que a coleta convencional tenha um valor de $\mathrm{R} \$ 72,00 / \mathrm{t}$ (SNIS, 2006), e a disposição em aterro sanitário de $R \$ 45,00 / t$ o valor total é de $R \$ 117,00 /$ t. Considerando-se ainda que os ganhos ambientais e sociais assumam um valor de $50 \%$ deste total chega-se ao valor indicativo da coleta seletiva de $R \$ 175,00 / t$ como adequado.

**Segundo SNIS 2006, a coleta re assume um percentual médio de $36,8 \%$ do custo do manejo de resíduos sólidos municipais. Se for atribuído um valor aproximado de $15 \%$ para o aterramento chega- se a um índice médio de $50 \%$ que se aproxima do percentual que as prefeituras gastam com coleta e aterramento. Isso sem contar as externalidades e outros ganhos de difícil mensuração.

Se você concordou parcialmente ou discordou de alguma das gradações, explique.

Questão 5- Avalie algumas características dos indicadores das organizações de catadores segundo a legenda abaixo, assinalando com $X(\operatorname{sim})$ as que considera que 0 indicador possui:

R- REPRESENTATIVIDADE = Relevância.

C- COMPARABILIDADE $=$ Amplitude geográfica adequada, padronização, e sensibilidade a mudanças no tempo.

CD- COLETA DE DADOS =Acessibilidade dos dados, confiabilidade da fonte. CS- CLAREZA E SÍNTESE $=$ Clareza na comunicação e capacidade de síntese.

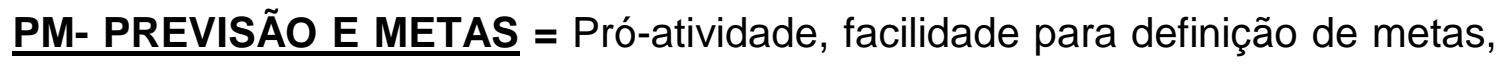
preditividade.

Após a avaliação das características do indicador dê uma nota de 0 a 10 para cada um segundo o grau de importância.

Em seguida, avalie o modo de cálculo do indicador, colocando C se concordar, CP se concordar parcialmente, e D se discordar. Se concordar parcialmente ou discordar, justifique. 


\begin{tabular}{|c|c|c|c|c|c|c|c|c|}
\hline Indicadores & $\mathrm{R}$ & $\mathrm{C}$ & $\mathrm{CP}$ & CS & PM & Nota & Modo de medição & Avaliação \\
\hline $\begin{array}{l}\text { 1. Percentual de atendimento aos requisitos } \\
\text { de regularização }\end{array}$ & & & & & & & $\frac{\text { N. de requisitos obrigatórios atendidos }}{\text { N. total de requisitos obrigatórios * }} \times 100$ & \\
\hline $\begin{array}{l}\text { 2. Implementação de instrumentos legais da } \\
\text { parceria com a prefeitura }\end{array}$ & & & & & & & $\begin{array}{l}\text { Atendimento aos requisitos legais de } \\
\text { contratação }\end{array}$ & \\
\hline $\begin{array}{l}\text { 3. Percentual de qualidade das parcerias em } \\
\text { relação às parcerias desejáveis. }\end{array}$ & & & & & & & $\frac{\text { N. parcerias efetivadas }}{\text { N. parcerias desejáveis }}{ }^{* *} \quad \times 100$ & \\
\hline $\begin{array}{l}\text { 4. Percentual de diversificação de parcerias } \\
\text { em relação às desejáveis. }\end{array}$ & & & & & & & $\frac{\text { N. de parcerias efetivadas }}{\text { N. de parcerias desejáveis }} \times 100$ & \\
\hline $\begin{array}{l}\text { 5. Percentual de diversificação das atividades } \\
\text { e serviços }\end{array}$ & & & & & & & $\frac{\text { N. de atividades e serviços }}{\text { N. total de atividades desejáveis }} \times 100$ & \\
\hline $\begin{array}{l}\text { 6. Percentual de atendimento aos requisitos } \\
\text { desejáveis de autogestão }\end{array}$ & & & & & & & $\frac{\text { N. de requisitos atendidos }}{\text { N. de requisitos desejáveis }} \times 100$ & \\
\hline $\begin{array}{l}\text { 7. Percentual de participação dos membros } \\
\text { em reuniões auto-gestionárias }\end{array}$ & & & & & & & $\frac{\text { N. membros que participaram das reuniões }}{N \text {. total de membros } \times \text { N. de reuniões }} \times 100$ & \\
\hline $\begin{array}{l}\text { 8. Percentual de membros capacitados em } \\
\text { relação ao total }\end{array}$ & & & & & & & $\frac{N . \text { atual de membros capacitados }}{N . \text { total atual de membros }} \times 100$ & \\
\hline $\begin{array}{l}\text { 10. Percentual de benefícios proporcionados } \\
\text { aos membros }\end{array}$ & & & & & & & $\frac{N \text { de benefícios efetivados } \times 100}{N . \text { de benefícios desejáveis }}{ }^{\star \star \star \star * \star}$ & \\
\hline 11. Renda média mensal por membro & & & & & & & $\begin{array}{l}\text { Renda média mensal por membro, } 6 \text { meses, e } \\
\text { em relação ao valor do salário mínimo. }\end{array}$ & \\
\hline 12. Eficiência da produtividade / catador & & & & & & & $\begin{array}{l}\text { Quantidade mensal de toneladas triada } \\
\text { por catador - média últimos } 6 \text { meses. }\end{array}$ & \\
\hline $\begin{array}{l}\text { 13. Percentual de equipamentos e veículos } \\
\text { próprios em relação aos cedidos }\end{array}$ & & & & & & & $\frac{\text { N. de veículos e equipamentos próprios }}{N \text {. total de veículos e equipamentos }} \times 100$ & \\
\hline $\begin{array}{l}\text { 14. Percentual de horas trabalhadas pelos } \\
\text { membros em relação às da organização }\end{array}$ & & & & & & & $\begin{array}{c}\text { N. total de horas trabalhadas pelos membros } \\
\text { N. total de horas de trabalho da organização } \\
\text { Média dos últimos } 6 \text { meses }\end{array}$ & \\
\hline $\begin{array}{l}\text { 15. Percentual de ganhos entre gêneros/ hora } \\
\text { trabalhada e atividade }\end{array}$ & & & & & & & $\begin{array}{l}\text { Ganho do gênero feminino por hora }(\mathrm{R} \$) \times 100 \\
\text { Ganho do gênero masculino por hora }(\mathrm{R} \$)\end{array}$ & \\
\hline $\begin{array}{l}\text { 16. Percentual de atendimento aos requisitos } \\
\text { de saúde no trabalho. }\end{array}$ & & & & & & & $\frac{\text { N. de requisitos atendidos } \times 100}{\text { N. de requisitos desejáveis }}{ }^{\star \star \star \star \star \star \star}$ & \\
\hline $\begin{array}{l}\text { 17. Percentual de atendimento aos requisitos } \\
\text { de segurança e salubridade }\end{array}$ & & & & & & & $\frac{\text { N. de requisitos atendidos }}{\text { N. de requisitos desejáveis }} \times 100$ & \\
\hline $\begin{array}{l}\text { 18. Percentual de membros que usam } \\
\text { equipamentos de proteção individual - }\end{array}$ & & & & & & & $\frac{\text { N. membros que usam EPIs }}{N \text {. total de membros }} \times 100$ & \\
\hline
\end{tabular}


* Cooperativas - Estatuto Social, Cadastro Nacional de Pessoa JurídicaCNPJ, Registro na OCE, Atas de Assembléias gerais, diretoria funcionando, recolhimento de impostos, recolhimento de Fundos obrigatórios (FAT - 5\% e Fundo de Reserva - 10\%), livros em dia, emissão de notas fiscais, balanço anual. Associações- Estatuto Social, Cadastro Nacional de Pessoa JurídicaCNPJ, Certidão Negativa do INSS, Certidão Negativa do FGTS, Certidão Negativa da Receita Federal, Livro de Matrícula dos Associados atualizado, últimas 3 (três) atas da Associação e Balancetes, ata de aprovação de contas do último exercício social.

** Capacitação, alfabetização, cessão de equipamentos, cessão de espaço, material de educação e comunicação, ações de educação e comunicação, cessão de materiais recicláveis, apoio técnico, construção de galpão de triagem.

*** Setor público municipal, estadual, federal, setor privado, organizações não governamentais, redes de organizações de catadores, catadores avulsos, entidades representativas dos catadores.

Educação ambiental, coleta, triagem, beneficiamento, reaproveitamento de materiais recicláveis, reciclagem, prestação de serviços a terceiros.

Reuniões de decisão auto-gestionária, regimento interno, instrumentos de transparência e rateio: informações sobre despesas, descontos, vendas e rateio, livros disponíveis, murais de comunicação e informação.

****** Férias remuneradas, afastamento maternidade, prêmios, convenio, curso de alfabetização, transporte, creche, licença remunerada, conta bancária.

******* Vacinação regular, prevenção de LER - lesão por esforços repetitivos, descanso pelo peso das atividades, limpeza e higiene no local de trabalho, exames médicos periódicos, comunicação visual nos ambientes, alimentação adequada, recolhimento de INSS pelos cooperados, prevenção, registro e atendimento aos acidentes de trabalho.

******** Rotina de limpeza, controle de vetores de doenças; ratos, moscas e barata, cobertura adequada, ventilação adequada, ausência de odores incômodos, sistema de prevenção de incêndios e outros. 


\begin{tabular}{|c|c|c|c|c|c|c|c|c|}
\hline \multirow[b]{2}{*}{ Indicadores } & \multicolumn{6}{|c|}{ Características } & \multirow[t]{2}{*}{ Modo de medição } & \multirow{2}{*}{$\begin{array}{l}\text { Avalia- } \\
\text { ção }\end{array}$} \\
\hline & $\mathbf{R}$ & C & CP & CS & PM & Nota & & \\
\hline $\begin{array}{l}\text { 1. Percentual de atendimento aos } \\
\text { requisitos de regularização }\end{array}$ & & & & & & & $\frac{\text { N. de requisitos obrigatórios atendidos }}{N . \text { total de requisitos obrigatórios * }} \times 100$ & \\
\hline $\begin{array}{l}\text { 2. Implementação de } \\
\text { instrumentos legais da parceria } \\
\text { com a prefeitura }\end{array}$ & & & & & & & $\begin{array}{l}\text { Atendimento aos requisitos legais de } \\
\text { contratação }\end{array}$ & \\
\hline $\begin{array}{l}\text { 3. Percentual de qualidade das } \\
\text { parcerias em relação às parcerias } \\
\text { desejáveis. }\end{array}$ & & & & & & & $\frac{\text { N. parcerias efetivadas }}{\text { N. parcerias desejáveis }}{ }^{* *} \quad \times 100$ & \\
\hline $\begin{array}{l}\text { 4. Percentual de diversificação de } \\
\text { parcerias em relação às } \\
\text { desejáveis. }\end{array}$ & & & & & & & $\frac{\text { N. de parcerias efetivadas }}{\text { N. de parcerias desejáveis }} \times 100$ & \\
\hline $\begin{array}{l}\text { 5. Percentual de diversificação } \\
\text { das atividades e serviços }\end{array}$ & & & & & & & $\frac{\text { N. de atividades e serviços }}{\text { N. total de atividades desejáveis }} \times 100$ & \\
\hline $\begin{array}{l}\text { 6. Percentual de atendimento aos } \\
\text { requisitos desejáveis de } \\
\text { autogestão }\end{array}$ & & & & & & & $\frac{\text { N. de requisitos atendidos }}{\text { N. de requisitos desejáveis }} \times 100$ & \\
\hline $\begin{array}{l}\text { 7. Percentual de participação dos } \\
\text { membros em reuniões auto- } \\
\text { gestionárias }\end{array}$ & & & & & & & $\begin{array}{l}\text { N. membros que participaram das reuniões } \\
100 \\
\text { N. total de membros } x \text { N. de reuniões }\end{array}$ & \\
\hline $\begin{array}{l}\text { 8. Percentual de membros } \\
\text { capacitados em relação ao total }\end{array}$ & & & & & & & $\frac{N . \text { atual de membros capacitados }}{N . \text { total atual de membros }} \times 100$ & \\
\hline $\begin{array}{l}\text { 9. Percentual de membros que } \\
\text { não permanecem (Rotatividade) }\end{array}$ & & & & & & & $\frac{\text { N. atual de membros }}{N \text {. total de membros últimos } 6 \text { meses }} \times 100$ & \\
\hline $\begin{array}{l}\text { 10. Percentual de benefícios } \\
\text { proporcionados aos membros }\end{array}$ & & & & & & & $\frac{N \text { de benefícios efetivados }}{N \text {. de benefícios desejáveis }} \times 100$ & \\
\hline
\end{tabular}




\begin{tabular}{|c|c|c|c|c|c|c|c|c|}
\hline \multirow[t]{2}{*}{ Indicadores } & \multicolumn{6}{|c|}{ Características } & \multirow[t]{2}{*}{ Modo de medição } & \multirow{2}{*}{$\begin{array}{l}\text { Avalia- } \\
\text { ção }\end{array}$} \\
\hline & $\mathbf{R}$ & C & CP & CS & PM & Nota & & \\
\hline $\begin{array}{l}\text { 11. Renda média mensal por } \\
\text { membro }\end{array}$ & & & & & & & $\begin{array}{l}\text { Renda média mensal por membro, } 6 \\
\text { meses, e em relação ao salário mínimo }\end{array}$ & \\
\hline $\begin{array}{l}\text { 12. Eficiência da produtividade / } \\
\text { catador }\end{array}$ & & & & & & & $\begin{array}{l}\text { Quantidade mensal de toneladas triada } \\
\text { por catador - média últimos } 6 \text { meses. }\end{array}$ & \\
\hline $\begin{array}{l}\text { 13. Percentual de equipamentos } \\
\text { e veículos próprios em relação } \\
\text { aos cedidos }\end{array}$ & & & & & & & $\frac{N . \text { de veículos e equipamentos próprios }}{N \text {. total de veículos e equipamentos }} \times 100$ & \\
\hline $\begin{array}{l}\text { 14. Percentual de horas } \\
\text { trabalhadas pelos membros em } \\
\text { relação às da organização }\end{array}$ & & & & & & & 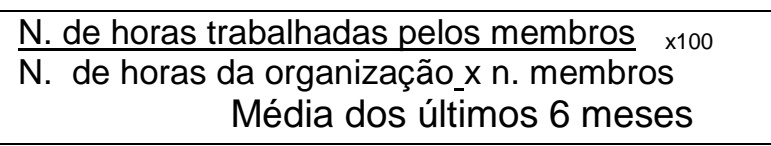 & \\
\hline $\begin{array}{l}15 . \text { Percentual de ganhos entre } \\
\text { gêneros/ hora trabalhada e } \\
\text { atividade }\end{array}$ & & & & & & & $\begin{array}{l}\text { Ganho do gênero feminino/ hora }(\mathrm{R} \$) \times 100 \\
\text { Ganho do gênero masculino/ hora }(\mathrm{R} \$)\end{array}$ & \\
\hline $\begin{array}{l}\text { 16. Percentual de atendimento } \\
\text { aos requisitos de saúde no } \\
\text { trabalho. }\end{array}$ & & & & & & & $\frac{N \text {. de requisitos atendidos }}{N . \text { de requisitos desejáveis }} \times 100$ & \\
\hline $\begin{array}{l}\text { 17. Percentual de atendimento } \\
\text { aos requisitos de segurança e } \\
\text { salubridade }\end{array}$ & & & & & & & $\frac{\text { N. de requisitos atendidos }}{\text { N. de requisitos desejáveis }} \times 100$ & \\
\hline $\begin{array}{l}\text { 18. Percentual de membros que } \\
\text { usam EPIs }\end{array}$ & & & & & & & $\frac{\text { N. membros que usam EPIs }}{\mathrm{N} \text {. total de membros }} \times 100$ & \\
\hline
\end{tabular}


*A gradação baseou-se no estudo Análise do custo de geração de postos de trabalho na economia urbana para o segmento de catadores de materiais recicláveis, realizado pelo Movimento Nacional dos Catadores de Materiais Recicláveis de janeiro de 2006.

Se você concordou parcialmente ou discordou de alguma das gradações,
explique:

JUSTIFICATIVA:

Questão 6 - Assinale com um X as respostas referentes às gradações dos indicadores das organizações de catadores. Se concordar com todas as gradações de um mesmo indicador assinale Concordo; se discordar de qualquer uma das gradações assinale Parcial, e se não concordar com nenhuma assinale Discordo. As gradações servem para calibrar os indicadores e definir se o que se quer medir está mais próximo ou mais distante da sustentabilidade. 


\begin{tabular}{|c|c|c|c|c|c|c|}
\hline \multirow[t]{2}{*}{ Indicador } & \multicolumn{3}{|c|}{ Tendências à sustentabilidade } & \multicolumn{3}{|c|}{ Avaliação } \\
\hline & Alta $(+)$ & Média (+/-) & Baixa (-) & C & $\mathrm{CP}$ & $\mathrm{D}$ \\
\hline $\begin{array}{l}\text { 1- Percentual de atendimento da população com } \\
\text { a coleta seletiva }\end{array}$ & $80 \%$ a $100 \%$ & $40,1 \%$ a $79,9 \%$ & $\leq 40 \%$ & & & \\
\hline 2- Percentual de adesão da população. & $\geq 80 \%$ & $40,1 \%$ a $79,9 \%$ & $\leq 40 \%$ & & & \\
\hline 3- Percentual de Parcerias do Programa & $80 \%$ a $100 \%$ & $50,1 \%$ a $80 \%$ & $\leq 50 \%$ & & & \\
\hline $\begin{array}{l}\text { 4- Freqüência de programa de educação e } \\
\text { divulgação }\end{array}$ & $\begin{array}{c}\text { Permanente } \\
\text { Quinzenal ou Mensal }\end{array}$ & Bi e Trimestral & Anual/pontual & & & \\
\hline $\begin{array}{l}\text { 5- Implementação da gestão compartilhada do } \\
\text { programa com a sociedade civil }\end{array}$ & Existe e funciona & $\begin{array}{l}\text { Existe, mas não } \\
\text { funciona bem }\end{array}$ & Não existe & & & \\
\hline 6- Percentual de inclusão de catadores avulsos. & $80 \%$ a $100 \%$ & $50,1 \%$ a $79,9 \%$ & $\leq 50 \%$ & & & \\
\hline $\begin{array}{l}\text { 7- Implementação de instrumentos legais na } \\
\text { relação com as organizações de catadores }\end{array}$ & $\begin{array}{l}\text { Contrato ou Convenio } \\
\text { com remuneração }\end{array}$ & $\begin{array}{l}\text { Convenio } \\
\text { sem remuneração }\end{array}$ & $\begin{array}{c}\text { Inexistência de } \\
\text { contrato ou } \\
\text { convenio }\end{array}$ & & & \\
\hline $\begin{array}{l}\text { 8- Percentual de recuperação de materiais } \\
\text { recicláveis em relação do total coletado. }\end{array}$ & $\geq 20 \%$ & $10,1 \%$ a $19,9 \%$ & $\leq 10 \%$ & & & \\
\hline 9- Percentual de Rejeito & $\leq 10 \%$ & $10,1 \%$ a $29,9 \%$ & $>30 \%$ & & & \\
\hline $\begin{array}{l}\text { 10- Percentual de adequação das condições de } \\
\text { trabalho na central de triagem. }\end{array}$ & $80 \%$ a $100 \%$ & $50,1 \%$ a $79 \%$ & $\leq 50 \%$ & & & \\
\hline $\begin{array}{l}\text { 11- Percentual de auto-financiamento do } \\
\text { programa. }\end{array}$ & $80 \%$ a $100 \%$ & $50,1 \%$ a $79,9 \%$ & $\leq 50 \%$ & & & \\
\hline $\begin{array}{l}\text { 12- Percentual do custo do programa em } \\
\text { relação ao custo do manejo de resíduos. }\end{array}$ & $\leq 50 \%$ & $50,1 \%$ a $74,9 \%$ & $\geq 75 \%$ & & & \\
\hline $\begin{array}{l}\text { 13. Custo do programa em relação à quantidade } \\
\text { coletada seletivamente }\end{array}$ & $\leq \mathrm{R} \$ 175,00 / \mathrm{t}$ & $\begin{array}{l}\mathrm{R} \$ 170,1 \text { a } \mathrm{R} \$ \\
350,00\end{array}$ & $\geq \mathrm{R} \$ 350,00 / \mathrm{t}$ & & & \\
\hline $\begin{array}{l}\text { 14- Percentual de custo da coleta seletiva em } \\
\text { relação à coleta regular e aterramento }\end{array}$ & $\leq 50 \%$ & $50,1 \%$ a $199,9 \%$ & $\geq 200 \%$ & & & \\
\hline
\end{tabular}




\section{APÊNDICE H}

\section{Proposta da Oficina de indicadores - Festival Lixo e Cidadania, 2009}

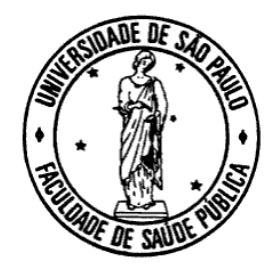

\section{UNIVERSIDADE DE SÃO PAULO FACULDADE DE SAÚDE PÚBLICA}

A oficina de indicadores de sustentabilidade proposta para o Festival Lixo e Cidadania tem por objetivo reunir, no máximo 30 representantes do Movimento Nacional dos Catadores, (selecionados pelo próprio Movimento, a partir de uma amostra que tenha representatividade Nacional), para realizar a construção e avaliação de indicadores de sustentabilidade voltados aos programas de coleta seletiva e organizações de catadores. Estes indicadores pretendem apoiar a gestão municipal da coleta seletiva em parceria com organizações de catadores no sentido de propor referencial para a avaliação da sustentabilidade de programas municipais em parceria com catadores.

Os resultados desta oficina serão incorporados ao processo de discussão e de validação destes indicadores no âmbito da Tese de Doutorado desenvolvida por Gina Rizpah Besen na FSP/USP - área de Saúde Ambiental. A Tese que será defendida em 2010, partiu dos indicadores da pesquisa: "Programas Municipais de Coleta Seletiva em Parceria com Cooperativas de Catadores na Região Metropolitana de São Paulo, como Fator de Sustentabilidade dos Sistemas de Limpeza Pública" (coordenada pela Faculdade de Saúde Pública, e desenvolvida em parceria com o PROCAM/USP e a gestão ambiental do SENAC com financiamento da FUNASA, 2005), e ampliou a discussão com especialistas, técnicos municipais, assessores de ONGs, membros dos Fóruns Lixo e Cidadania e acadêmicos de várias regiões do país. 
Com relação ao segmento das organizações de catadores, considerouse que se deveria buscar ouvir as representações do Movimento Nacional dos Catadores, em lugar de representações isoladas de catadores, o que vai possibilitar uma ampliação da discussão das diferentes visões e dos indicadores propostos e validados pelos dois grupos, ou por cada um dos grupos. A duração da oficina será de 3 horas. 
APÊNDICE I - Coleta seletiva na Região Metropolitana de São Paulo, 2010

Parceria com organizações de catadores, número de organizações, número de membros, ano de inicio, abrangência quantidade de material comercializado e renda média dos membros das organizações.

\begin{tabular}{|c|c|c|c|c|c|c|c|c|}
\hline Município & $\begin{array}{l}\text { Coleta } \\
\text { Seletiva }\end{array}$ & $\begin{array}{l}\text { Parceria com } \\
\text { organizações } \\
\text { de catadores }\end{array}$ & $\begin{array}{l}\text { Organi- } \\
\text { zações } \\
\text { (NN) }\end{array}$ & $\begin{array}{c}\text { Membros } \\
\text { (№) }\end{array}$ & $\begin{array}{l}\text { Ano de } \\
\text { Início }\end{array}$ & Abrangência $_{(\%)}$ & $\begin{array}{c}\text { Material } \\
\text { Comercializado } \\
\text { (t/mês) }\end{array}$ & $\begin{array}{c}\text { Renda média } \\
\text { por membro } \\
(R \$)\end{array}$ \\
\hline Arujá & Sim & Associação & 1 & 32 & 2004 & $100 \%$ & 30 & 350,00 \\
\hline Barueri & Sim & Cooperativa & 1 & 120 & 2002 & $100 \%$ & 240 & 700,00 \\
\hline Biritiba Mirim & Sim & Cooperativa & 1 & 20 & 2004 & $35 \%$ & 24 & 450,00 \\
\hline Cajamar & Não & Tem Projeto & --- & --- & --- & --- & --- & --- \\
\hline Carapicuíba & Não & Tem Projeto & --- & --- & --- & --- & --- & --- \\
\hline Cotia & Sim & Cooperativa & 1 & 28 & 2008 & $10 \%$ & 120 & 750,00 \\
\hline Diadema & Sim & $\begin{array}{l}\text { Associação } \\
\text { Cooperativa }\end{array}$ & $\begin{array}{l}1 \\
1 \\
\end{array}$ & 56 & 2000 & $35 \%$ & 120 & 700,00 \\
\hline Embu-Guaçu & Sim & Associação & 1 & 30 & 2007 & $10 \%$ & 19 & 450,00 \\
\hline Ferraz de V. & Sim & Associação & 1 & 9 & 2009 & NR & 15 & 175,00 \\
\hline Francisco M. & Não & Tem Projeto & --- & --- & --- & --- & --- & --- \\
\hline
\end{tabular}




\begin{tabular}{|c|c|c|c|c|c|c|c|c|}
\hline Município & $\begin{array}{l}\text { Coleta } \\
\text { Seletiva }\end{array}$ & $\begin{array}{l}\text { Parceria com } \\
\text { organizações } \\
\text { de catadores }\end{array}$ & $\begin{array}{l}\text { Organi- } \\
\text { zações } \\
\text { (№) }\end{array}$ & $\begin{array}{l}\text { Membros } \\
\text { (№) }\end{array}$ & $\begin{array}{l}\text { Ano de } \\
\text { Início }\end{array}$ & Abrangência $_{(\%)}$ & $\begin{array}{c}\text { Material } \\
\text { Comercializado } \\
\text { (t/mês) }\end{array}$ & $\begin{array}{c}\text { Renda média } \\
\text { por membro } \\
(\mathrm{R} \$)\end{array}$ \\
\hline Franco da R. & Não & Tem projeto & --- & --- & --- & --- & --- & --- \\
\hline Guararema & Não & $\begin{array}{l}\text { Não Tem } \\
\text { projeto }\end{array}$ & --- & --- & --- & --- & --- & --- \\
\hline Guarulhos & Sim & Cooperativa & 1 & 47 & 2005 & $6 \%$ & 100 & 650,00 \\
\hline $\begin{array}{l}\text { Itapecerica da } \\
\text { Serra }\end{array}$ & Sim & Cooperativa & 1. & 25 & 2007 & NTI & 70 & 550,00 \\
\hline Itapevi & Sim & Cooperativa & 1 & 20 & 2004 & $10 \%$ & 35 & 500,00 \\
\hline Itaquaquecetuba & Não & Não Tem & --- & --- & --- & --- & --- & --- \\
\hline Jandira & Sim & Cooperativa & 1 & 20 & 2001 & $30 \%$ & 70 & 450,00 \\
\hline Juquitiba & Sim & Cooperativa. & 1 & 27 & 2009 & $70 \%$ & 43 & 550,00 \\
\hline Mairiporã & Não & $\begin{array}{l}\text { Projeto } \\
\text { indefinido }\end{array}$ & --- & --- & --- & --- & --- & --- \\
\hline Mauá & Sim & Cooperativa & 1 & 20 & 2004 & $1 \%$ & 40 & 450,00 \\
\hline Mogi das Cruzes & Sim & Não formalizado & --- & 12 & 2008 & $80 \%$ & 40 & 400,00 \\
\hline Osasco & Sim & Cooperativas & 2 & $\begin{array}{c}41 \text { e } 46 \\
87\end{array}$ & 2009 & $30 \%$ & 120 & 800,00 \\
\hline $\begin{array}{l}\text { Pirapora do Bom } \\
\text { Jesus }\end{array}$ & Sim & Associação & 1 & 10 & 2007 & $15 \%$ & 7,5 & 250,00 \\
\hline Poá & Sim & Cooperativa & 1 & 35 & 2004 & $35 \%$ & 47 & 450,00 \\
\hline Ribeirão Pires & Sim & Cooperativa & 1 & 20 & 2004 & $8 \%$ & 37 & 400,00 \\
\hline $\begin{array}{l}\text { Rio Grande da } \\
\text { Serra }\end{array}$ & Não & Tem Projeto & --- & --- & --- & --- & --- & --- \\
\hline Salesópolis & Sim & Associação & 1 & 14 & 2004 & $100 \%$ & 20 & 400,00 \\
\hline
\end{tabular}




\begin{tabular}{|c|c|c|c|c|c|c|c|c|}
\hline Município & $\begin{array}{l}\text { Coleta } \\
\text { Seletiva }\end{array}$ & $\begin{array}{l}\text { Parceria com } \\
\text { organizações } \\
\text { de catadores }\end{array}$ & $\begin{array}{l}\text { Organi- } \\
\text { zações } \\
\text { (№) }\end{array}$ & $\begin{array}{l}\text { Membros } \\
\text { (№) }\end{array}$ & $\begin{array}{l}\text { Ano de } \\
\text { Início }\end{array}$ & Abrangência $_{(\%)}$ & $\begin{array}{c}\text { Material } \\
\text { Comercializado } \\
\text { (t/mês) }\end{array}$ & $\begin{array}{c}\text { Renda média } \\
\text { por membro } \\
\text { (R\$) }\end{array}$ \\
\hline Santa Isabel & Não & Tem projeto & --- & --- & --- & --- & --- & --- \\
\hline $\begin{array}{l}\text { Santana de } \\
\text { Parnaíba }\end{array}$ & Sim & Cooperativa & 1 & 85 & 2000 & $100 \%$ & 300 & 800,00 \\
\hline Santo André & Sim & Cooperativas & 2 & 240 & 1998 & $100 \%$ & 630 & 525,00 \\
\hline S. Bernardo do C. & Sim & Associações & 2 & 97 & 2000 & $60 \%$ & 364 & $1.000,00$ \\
\hline São Caetano Sul & Sim & $\begin{array}{c}\text { Projeto } \\
\text { indefinido }\end{array}$ & --- & --- & 2005 & $100 \%$ & 110 & --- \\
\hline $\begin{array}{l}\text { São Lourenço da } \\
\text { Serra }\end{array}$ & Sim & $\begin{array}{l}\text { Coop. em outro } \\
\text { municipio }\end{array}$ & --- & --- & 2008 & $100 \%$ & 1 & --- \\
\hline São Paulo & Sim & Cooperativas & 18 & 1049 & 2003 & $20 \%$ hab. & 3135 & 700,00 \\
\hline Suzano & Sim & Cooperativa & 1 & 20 & 2004 & $3 \%$ & 10 & 450,00 \\
\hline Taboão da Serra & Sim & Cooperativa & 1 & 23 & 2007 & $5 \%$ & 4 & 140,00 \\
\hline Vargem Gde. Pta. & Sim & Cooperativa & 1 & 8 & 2004 & $6 \%$ & 12 & 450,00 \\
\hline
\end{tabular}

Elaborada pela autora com dados das prefeituras, de março 2010. 


\section{APÊNDICE J}

Dados da coleta seletiva na RMSP, período 2005 a 2010

Variação percentual da taxa de recuperação de materiais recicláveis- TRMR da coleta seletiva, do número de membros das organizações de catadores e da renda média na RMSP, no período de 2005 a 2010.

\begin{tabular}{|l|c|c|c|}
\hline \multirow{2}{*}{ Município } & \multicolumn{3}{|c|}{ Evolução } \\
\cline { 2 - 4 } & $\begin{array}{c}\text { TRMR } \\
(\%)\end{array}$ & $\begin{array}{c}\text { N de membros } \\
(\%)\end{array}$ & $\begin{array}{c}\text { Renda média dos } \\
\text { membros* } \\
(\%)\end{array}$ \\
\hline Barueri & 90 & 216 & -60 \\
\hline Diadema & 900 & 75 & -40 \\
\hline Embu & 108 & 87 & -61 \\
\hline Itapecerica da Serra & 183 & 150 & 100 \\
\hline Poá & 191 & 17 & -10 \\
\hline Santana de Parnaíba & 700 & 77 & -16 \\
\hline Santo André & 227 & 36 & -23 \\
\hline S. Bernardo do Campo & 525 & 56 & 0 \\
\hline São Paulo & 57 & 58 & -30 \\
\hline
\end{tabular}

*Em salários mínimos.

Elaborada pela autora com dados das prefeituras municipais,em março de 2010. 


\section{APÊNDICE K}

Variação percentual de membros- organizações de catadores, desde o início de funcionamento até 2005, do início até 2010 e entre 2005 e 2010, na RMSP

\begin{tabular}{|l|c|c|c|}
\hline \multirow{2}{*}{ Municípios } & \multicolumn{3}{|c|}{ Evolução (\%) } \\
\cline { 2 - 4 } & Inicio até 2010 & Inicio até 2005 & 2005 a 2010 \\
\hline Barueri & 400 & 58 & 216 \\
\hline Biritiba-Mirim & 0 & 30 & -23 \\
\hline Diadema & -11 & -49 & 75 \\
\hline Embu & 180 & 50 & 87 \\
\hline $\begin{array}{l}\text { Itapecerica da } \\
\text { Serra }\end{array}$ & 9 & -56 & 150 \\
\hline Itapevi & 0 & 0 & 0 \\
\hline Jandira & 67 & 0 & 67 \\
\hline Mauá & 0 & 0 & 190 \\
\hline Osasco & 314 & 43 & 17 \\
\hline Poá & 75 & 50 & 11 \\
\hline Ribeirão Pires & 0 & 11 & -36 \\
\hline Salesópolis & 0 & $-36,4$ & 77 \\
\hline $\begin{array}{l}\text { Santana de } \\
\text { Parnaíba }\end{array}$ & 42 & -20 & 56 \\
\hline Santo André & 411 & 274 & 58 \\
\hline $\begin{array}{l}\text { S. Bernardo do } \\
\text { Campo }\end{array}$ & 142 & 55,3 & \\
\hline São Paulo & 150 & & 56 \\
\hline
\end{tabular}

Elaborada pela autora com dados das prefeituras, em março de 2010 e de RIBEIRO et al., 2009 
APENDICE L - Dados das organizações de catadores, 2004 e 2010

Número de organizações parceiras, número de membros, média por membro e quantidade média renda de recicláveis comercializada, em 2005 e 2010

\begin{tabular}{|c|c|c|c|c|c|c|c|c|}
\hline \multirow{2}{*}{ Municípios } & \multicolumn{2}{|c|}{$\begin{array}{c}\text { № de organizações } \\
\text { parceiras }\end{array}$} & \multicolumn{2}{|c|}{ № de membros } & \multicolumn{2}{|c|}{$\begin{array}{l}\text { Renda média } \\
\text { membro (R\$) }\end{array}$} & \multicolumn{2}{|c|}{$\begin{array}{c}\text { Quantidade média } \\
\text { comercializada (T/mês) }\end{array}$} \\
\hline & 2005 & 2010 & 2005 & 2010 & 2005 & 2010 & 2005 & 2010 \\
\hline Arujá & --- & 1 & --- & 32 & --- & 350,00 & --- & 30,0 \\
\hline Barueri & 1 & 1 & 38 & 120 & 920,00 & 700,00 & 70,0 & 240,0 \\
\hline Biritiba-Mirim & 1 & 1 & 26 & 20 & --- & 450,00 & 20,0 & 24,0 \\
\hline Caieiras & --- & --- & $\begin{array}{c}-- \\
\end{array}$ & --- & --- & --- & --- & --- \\
\hline Cajamar & --- & --- & --- & --- & --- & --- & --- & --- \\
\hline Carapicuíba & 1 & --- & 40 & $\begin{array}{l}-- \\
-1\end{array}$ & 350,00 & --- & 40,0 & $\begin{array}{c}-- \\
-1\end{array}$ \\
\hline Cotia & --- & 1 & --- & 28 & --- & 750,00 & --- & 120,0 \\
\hline Diadema & 1 & 2 & 32 & 56 & 265,00 & 700,00 & 54,0 & 120,0 \\
\hline Embu & 1 & 2 & 30 & 56 & 600,00 & 450,00 & 52,0 & 110,0 \\
\hline Embu-Guaçu & --- & 1 & --- & 30 & --- & 450,00 & --- & 19,0 \\
\hline Ferraz de Vasconcelos & --- & 1 & $-\cdots$ & 9 & --- & 175,00 & --- & 15,0 \\
\hline Francisco Morato & --- & --- & --- & --- & --- & --- & --- & --- \\
\hline Franco da Rocha & --- & --- & --- & --- & --- & --- & --- & --- \\
\hline Guararema & --- & --- & --- & --- & --- & --- & -- & --- \\
\hline Guarulhos & --- & 1 & --- & 47 & --- & 800,00 & --- & 100,0 \\
\hline Itapecerica da Serra & 1 & 1 & 10 & 25 & 125,00 & 550,00 & 28,5 & 70,0 \\
\hline Itapevi & 1 & 1 & 20 & 20 & --- & 500,00 & 10,0 & 35,0 \\
\hline
\end{tabular}




\begin{tabular}{|c|c|c|c|c|c|c|c|c|}
\hline \multirow{2}{*}{ Municípios } & \multicolumn{2}{|c|}{ № de organizações parceiras } & \multicolumn{2}{|c|}{ № de membros } & \multicolumn{2}{|c|}{ Renda média (R\$) } & \multicolumn{2}{|c|}{$\begin{array}{c}\text { Quantidade média } \\
\text { comercializada (t/mês) }\end{array}$} \\
\hline & 2005 & 2010 & 2005 & 2010 & 2005 & 2010 & 2005 & 2010 \\
\hline Itaquaquecetuba & --- & --- & --- & --- & --- & --- & --- & --- \\
\hline Jandira & 1 & 1 & 12 & 20 & 280,00 & 450,00 & 3,0 & 70,0 \\
\hline Juquitiba & --- & 1 & --- & 27 & --- & 550,00 & --- & 43,0 \\
\hline Mairiporã & --- & --- & --- & --- & --- & --- & --- & --- \\
\hline Mauá & 1 & 1 & 20 & 20 & --- & 450,00 & 11,0 & 40,0 \\
\hline Mogi das Cruzes & --- & --- & --- & 12 & --- & 800,00 & --- & 40,0 \\
\hline Osasco & 1 & 2 & 30 & 87 & --- & 800,00 & --- & 120,0 \\
\hline Pirapora do Bom Jesus & --- & 1 & --- & 10 & --- & 250,00 & --- & 7,5 \\
\hline Poá & 1 & 1 & 48 & 35 & 275,00 & 450,00 & 23,0 & 47,0 \\
\hline Ribeirão Pires & 1 & 1 & 18 & 20 & --- & 400,00 & 5,0 & 37,0 \\
\hline Rio Grande da Serra & -- & -- & --- & --- & --- & --- & -- & --- \\
\hline Salesópolis & 1 & 1 & 22 & 14 & --- & 400,00 & --- & 20,0 \\
\hline Santa Isabel & --- & -- & --- & --- & --- & --- & --- & - \\
\hline Santana de Parnaíba & 1 & 1 & 48 & 85 & 500,00 & 800,00 & 45,0 & 300,0 \\
\hline Santo André & 2 & 2 & 176 & 240 & 332,50 & 525,00 & 500,0 & 630,0 \\
\hline S. Bernardo do Campo & 2 & 2 & 62 & 97 & 530,00 & $1.000,00$ & 88,0 & 364,0 \\
\hline São Caetano do Sul & -- & --- & --- & --- & --- & --- & --- & 110,0 \\
\hline São Lourenço da Serra & -- & --- & --- & $\begin{array}{c}-- \\
\end{array}$ & --- & --- & $\mid--$ & 1,0 \\
\hline São Paulo & 15 & 18 & 665 & 1049 & 518,00 & 700,00 & $1.670,0$ & $3.135,0$ \\
\hline Suzano & 1 & 1 & 20 & 20 & --- & 450,00 & 10,0 & 10,0 \\
\hline Taboão da Serra & --- & 1 & --- & 23 & --- & 140,00 & --- & 4,0 \\
\hline Vargem Gde. Paulista & 1 & 1 & 10 & 8 & -- & 450,00 & 12,0 & 12,0 \\
\hline
\end{tabular}




\begin{tabular}{|c|c|c|c|c|c|c|c|c|}
\hline \multirow[t]{2}{*}{ Municípios } & \multicolumn{2}{|c|}{$\begin{array}{l}\text { № de organizações } \\
\text { parceiras }\end{array}$} & \multicolumn{2}{|c|}{ № de membros } & \multicolumn{2}{|c|}{$\begin{array}{l}\text { Renda média por } \\
\text { membro (R\$) }\end{array}$} & \multicolumn{2}{|c|}{$\begin{array}{l}\text { Quantidade média } \\
\text { comercializada (t/mês) }\end{array}$} \\
\hline & 2005 & 2010 & 2005 & 2010 & 2005 & 2010 & 2005 & 2010 \\
\hline Sem São Paulo & 20 & 30 & 662 & 1.161 & Média & Média & 971,5 & $2.738,5$ \\
\hline Total & 35 & 48 & 1.327 & 2.210 & $\begin{array}{l}\text { Média } \\
427,00\end{array}$ & $\begin{array}{l}\text { Média } \\
537,00\end{array}$ & $2.641,5$ & $5.873,5$ \\
\hline
\end{tabular}




\section{APÊNDICE M}

Organizações de catadores; membros, renda média per capita, quantidade média comercializada e produtividade per capita, 2010.

\begin{tabular}{|c|c|c|c|c|}
\hline \multirow[t]{2}{*}{ Municípios } & \multicolumn{4}{|c|}{ Organizações de catadores } \\
\hline & N. membros & $\begin{array}{l}\text { Renda média } \\
\text { per capita } \\
(\mathrm{R} \$)\end{array}$ & $\begin{array}{c}\text { Quantidade média } \\
\text { comercializada } \\
\text { (kg/mês) }\end{array}$ & $\begin{array}{c}\text { Produtividade per } \\
\text { capita } \\
\text { (Kg /mês) }\end{array}$ \\
\hline Arujá & 32 & 350,00 & 30.000 & 937 \\
\hline Barueri & 120 & 700,00 & 240.000 & 2000 \\
\hline Biritiba-Mirim & 20 & 450,00 & 24.000 & 1200 \\
\hline Cotia & 28 & 750,00 & 120.000 & 4286 \\
\hline Diadema & 56 & 700,00 & 120.000 & 2143 \\
\hline Embu & 56 & 450,00 & 110.000 & 1964 \\
\hline Embu-Guaçu & 30 & 450,00 & 19.000 & 633 \\
\hline Ferraz de Vasconcelos & 9 & 175,00 & 15.000 & 1667 \\
\hline Guarulhos & 47 & 800,00 & 100.000 & 2128 \\
\hline Itapecerica da Serra & 25 & 550,00 & 70.000 & 2800 \\
\hline Itapevi & 20 & 500,00 & 35.000 & 1750 \\
\hline Jandira & 20 & 450,00 & 70.000 & 3500 \\
\hline Juquitiba & 27 & 550,00 & 43.000 & 1593 \\
\hline Mauá & 20 & 450,00 & 40.000 & 2000 \\
\hline Mogi das Cruzes & 12 & 800,00 & 40.000 & 3333 \\
\hline Osasco & 87 & 800,00 & 120.000 & 1379 \\
\hline Pirapora do Bom Jesus & 10 & 250,00 & 7.500 & 750 \\
\hline Poá & 35 & 450,00 & 47.000 & 1343 \\
\hline Ribeirão Pires & 20 & 400,00 & 37.000 & 1850 \\
\hline Salesópolis & 14 & 400,00 & 20.000 & 1429 \\
\hline Santana de Parnaíba & 85 & 800,00 & 300.000 & 3529 \\
\hline Santo André & 240 & 525,00 & 630.000 & 2625 \\
\hline S. Bernardo do Campo & 97 & $1.000,00$ & 364.000 & 3752 \\
\hline São Paulo & 1049 & 700,00 & 3.135 .000 & 2989 \\
\hline Suzano & 20 & 450,00 & 10.000 & 500 \\
\hline Taboão da Serra & 23 & 140,00 & 4.000 & 174 \\
\hline Vargem Gde. Paulista & 8 & 450,00 & 12.000 & 1500 \\
\hline
\end{tabular}




\section{APENDICE N}

Avaliação de indicadores - $1^{\text {a }}$ Rodada do Delphi com especialistas

\begin{tabular}{|c|c|c|c|c|c|c|c|c|c|c|}
\hline \multicolumn{11}{|c|}{ Avaliação dos indicadores da coleta seletiva $-1^{\text {a }}$ rodada } \\
\hline & V & \multicolumn{5}{|c|}{ Notas } & $\mathrm{V}$ & \multicolumn{3}{|c|}{$\begin{array}{c}\text { Tendências à } \\
\text { sustentabilidade }\end{array}$} \\
\hline & & $M A+A$ & MA & A & M & $\mathrm{B}$ & & C & $\mathrm{CP}$ & $\mathrm{D}$ \\
\hline 1- Sust. Econômica & 59 & 81,4 & 47,5 & 33,9 & 11,8 & 6,8 & 59 & 55,9 & 25,5 & 18,6 \\
\hline 2- Marco legal & 58 & 74,3 & 46,4 & 27,3 & 15,8 & 10,2 & 59 & 86,4 & 13,6 & - \\
\hline 3- Parcerias & 58 & 79,2 & 37,9 & 41,3 & 13,9 & 6,9 & 58 & 74,1 & 20,7 & 5,2 \\
\hline 4- Cobertura & 57 & 86,0 & 42,1 & 43,9 & 8,8 & 5,2 & 59 & 83,1 & 10,1 & 7,8 \\
\hline $5-\mathrm{TRMR}$ & 56 & 87,7 & 46,4 & 41,3 & 8,9 & 1,8 & 59 & 78,0 & 16,9 & 5,1 \\
\hline 6 - Rejeito & 56 & 83,9 & 48,1 & 35,8 & 8,9 & 7,2 & 58 & 82,8 & 13,8 & 3,4 \\
\hline \multicolumn{11}{|c|}{ Avaliação dos indicadores das organizações de catadores $-1^{\mathrm{a}}$ rodada } \\
\hline 1- Regularização & 59 & 77,9 & 55,9 & 22,0 & 8,5 & 13,6 & 59 & 91,5 & 8,5 & - \\
\hline $\begin{array}{l}2 \text { - Instrumento } \\
\text { legal da parceria }\end{array}$ & 58 & 74,2 & 43,1 & 31,1 & 18,9 & 6,9 & 57 & 75,4 & 21,1 & 3,5 \\
\hline 3 - Rotatividade & 53 & 39,7 & 15,1 & 24,6 & 35,8 & 24,5 & 56 & 76,8 & 12,5 & 10,7 \\
\hline 4 - Capacitação & 59 & 91,5 & 57,6 & 33,9 & 6,8 & 1,7 & 59 & 64,4 & 27,1 & 8,5 \\
\hline 5- Renda mensal & 56 & 91,0 & 53,5 & 37,5 & 5,4 & 3,6 & 58 & 67,2 & 29,3 & 3,4 \\
\hline 6 - Participação & 56 & 92,8 & 57,1 & 35,7 & 3,6 & 3,6 & 57 & 86,0 & 8,8 & 5,2 \\
\hline 7- Instalação & 57 & 57,8 & 31,5 & 26,3 & 19,3 & 22,9 & 58 & 67,2 & 27,6 & 5,2 \\
\hline 8- Equipamentos & 58 & 70,9 & 31,1 & 39,8 & 20,5 & 8,6 & 58 & 77,6 & 19,0 & 3,4 \\
\hline $\begin{array}{l}\text { 9- Horas de } \\
\text { trabalho }\end{array}$ & 57 & 68,5 & 21,1 & 47,4 & 19,3 & 12,2 & 59 & 67,8 & 20,3 & 11,9 \\
\hline 10- Beneficios & 58 & 74,3 & 32,9 & 41,4 & 13,7 & 12,0 & 52 & 78,8 & 13,5 & 7,7 \\
\hline 11- Uso de EPIS & 58 & 79,3 & 50 & 29,3 & 15,5 & 5,2 & 57 & 87,7 & 12,3 & -- \\
\hline 12- Parcerias & 56 & 87,4 & 46,4 & 41,0 & 7,2 & 5,4 & 55 & 70,9 & 21,8 & 7,3 \\
\hline
\end{tabular}

$M A=$ muito alta $=$ nota 10; $A=$ alta $=$ notas 8 e 9; $m=$ Média $=$ notas 6 e $7 ; B=$ baixa $=$ de 0 a 5

$\mathrm{V}=\mathrm{n}$. de questionários válidos.

Tendências à sustentabilidade: $\mathrm{C}=$ concorda, $\mathrm{CP}=$ concorda parcialmente, $\mathrm{D}=$ discorda 


\section{APÊNDICE $O$}

Indicadores de coleta seletiva e de organizações de catadores, modo de medição e tendências à sustentabilidade

APÊNDICE 1- Indicadores de coleta seletiva

\begin{tabular}{|c|c|c|c|c|c|}
\hline \multicolumn{6}{|c|}{ Indicadores de coleta seletiva } \\
\hline & & \multirow[b]{2}{*}{ Modo de medição } & \multicolumn{3}{|c|}{ Tendência à sustentabilidade } \\
\hline & & & Muito Favorável & Favorável & Desfavorável \\
\hline 1 & Adesão da população & $\frac{N . \text { de residências que aderem à coleta seletiva }}{N \text {. total de residências atendidas pela seletiva }} \times 100$ & $\geq 80 \%$ & $40,1 \%-79,9 \%$ & $\leq 40 \%$ \\
\hline 2 & $\begin{array}{l}\text { Taxa de recuperação de } \\
\text { recicláveis - TRMR }\end{array}$ & $\frac{\text { Q.da coleta seletiva }-Q \text {. de rejeitos }}{Q . \text { coletada seletiva }+Q \text { coleta regular }} \times 100$ & $\geq 20 \%$ & $10,1 \%-19,9 \%$ & $\leq 10 \%$ \\
\hline 3 & Atendimento da população & $\begin{array}{l}\text { N. de habitantes atendidos pela coleta seletiva } \\
\text { N. total de habitantes do município }\end{array} 100$ & $\geq 80 \%$ & $40,1 \%-79,9 \%$ & $\leq 40 \%$ \\
\hline 4 & Taxa de rejeito & $\begin{array}{l}\text { Q. da coleta seletiva }-Q \text {. comercializada } \\
\text { Q. da coleta seletiva }\end{array}$ & $\leq 10 \%$ & $10,1 \%-29,9 \%$ & $>30 \%$ \\
\hline 5 & Condições de trabalho & $\frac{\text { N. de requisitos atendidos }}{N . \text { de requisitos desejáveis }} \times 100$ & $\geq 80 \%$ & $50,1 \%-79,9 \%$ & $\leq 50 \%$ \\
\hline 6 & $\begin{array}{l}\text { Custo da coleta seletiva/coleta } \\
\text { regular e destinação final }\end{array}$ & $\begin{array}{ll}\text { Custo da coleta seletiva }(\mathrm{R} \$ / \mathrm{t}) & \times 100 \\
\text { Custo da coleta regular + e destinação final }(\mathrm{R} \$ / \mathrm{t})\end{array}$ & $\leq 50 \%$ & $50,1 \%-199,9 \%$ & $\geq 200 \%$ \\
\hline 7 & $\begin{array}{l}\text { Instrumentos legais na relação } \\
\text { com as org. de catadores }\end{array}$ & Existência ou não & $\begin{array}{l}\text { Contrato ou } \\
\text { Convenio com } \\
\text { remuneração }\end{array}$ & $\begin{array}{l}\text { Convenio } \\
\text { sem } \\
\text { remuneração }\end{array}$ & $\begin{array}{l}\text { Não há } \\
\text { contrato ou } \\
\text { convenio }\end{array}$ \\
\hline
\end{tabular}




\begin{tabular}{|c|c|c|c|c|c|}
\hline \multicolumn{6}{|c|}{ Continuação: Indicadores de coleta seletiva } \\
\hline & & \multirow[b]{2}{*}{ Modo de medição } & \multicolumn{3}{|c|}{ Tendência à sustentabilidade } \\
\hline & & & Muito Favorável & Favorável & Desfavorável \\
\hline 8 & $\begin{array}{l}\text { Custo do serviço/ quantidade } \\
\text { seletiva }\end{array}$ & $\frac{\text { Custo total da coleta seletiva }(\mathrm{R} \$)}{\text { Quantidade da coleta seletiva }}$ & $\leq \mathrm{R} \$ 175,00 / \mathrm{t}$ & $\begin{array}{l}\mathrm{R} \$ 174,99 \mathrm{a} \\
\mathrm{R} \$ 350,00\end{array}$ & $\geq \mathrm{R} \$ 350,00 / \mathrm{t}$ \\
\hline 9 & Educação /divulgação & Freqüência anual de atividades desenvolvidas & $\begin{array}{l}\text { Permanente } \\
\text { Quinzenal ou } \\
\text { Mensal }\end{array}$ & $\begin{array}{l}\text { Bimestral e } \\
\text { Trimestral }\end{array}$ & Anual/pontual \\
\hline 10 & $\begin{array}{l}\text { Custo da coleta seletiva / } \\
\text { manejo de RS }\end{array}$ & $\begin{array}{l}\text { Total de despesas da coleta seletiva }(R \$) \times 100 \\
\text { Total de despesas com os serviços } \\
\text { de manejo de resíduos sólidos }(R \$)\end{array}$ & $\leq 50 \%$ & $50,1 \%-74,9 \%$ & $\geq 75 \%$ \\
\hline 11 & Inclusão de catadores avulsos & $\frac{\mathrm{N} \text { de catadores avulsos incluídos }}{\mathrm{N} \text {. de catadores avulsos existentes }} \times 100$ & $\geq 80 \%$ & $50,1 \%-79,9 \%$ & $\leq 50 \%$ \\
\hline 12 & Autofinanciamento & $\frac{\text { Recursos do IPTU e/ou de taxa de lixo }(\mathrm{R} \$)}{\text { Custo da coleta seletiva }(\mathrm{R} \$)} \times 100$ & $\geq 80 \%$ & $50,1 \%-79,9 \%$ & $\leq 50 \%$ \\
\hline 13 & Gestão compartilhada & $\begin{array}{l}\text { Existência ou não de canais efetivos de } \\
\text { participação da sociedade civil e de } \\
\text { organizações de catadores } \\
\text { **** }\end{array}$ & Existe e funciona & $\begin{array}{l}\text { Existe, mas não } \\
\text { funciona bem }\end{array}$ & Não existe \\
\hline 14 & Percentual de Parcerias & 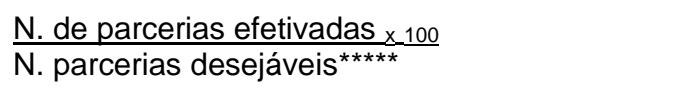 & $\geq 80 \%$ & $50,1 \%-79,9 \%$ & $\leq 50 \%$ \\
\hline
\end{tabular}

\section{Q- quantidade}

* Recomendam-se o atendimento aos requisitos do Ministério da Saúde e Trabalho: Princípios de higiene e limpeza, controle de vetores de doenças, ausência de ratos, moscas e baratas, cobertura adequada, ventilação adequada, ausência de odores incômodos, sistema de prevenção de riscos acidentes e incêndios, plano de emergência, uso de EPIS, identificação de materiais perigosos, e outros.

** Segundo o SNIS 2006, a coleta reassume um percentual médio de 36,8\% do custo do manejo de resíduos sólidos municipais. Se for atribuído um valor aproximado de $15 \%$ para o aterramento chega- se a um índice médio de $50 \%$ que se aproxima do percentual que as prefeituras gastam com coleta e aterramento. Este cálculo não inclui as externalidades e outros ganhos de difícil mensuração.

${ }^{* * \star} \mathrm{O}$ valor de $\mathrm{R} \$ 175,00 /$ foi considerado viável e baixo para a coleta seletiva a partir dos seguintes cálculos: $\mathrm{R} \$ 72,00 / t$ é o valor médio para a coleta convencional apurado pelo SNIS 2006 (R\$61,32/t.) e reajustado em 17,5\% (agosto de 2008 pelo IGPm). Considerando-se que a coleta convencional tenha um valor de $\mathrm{R} \$ 72,00 / \mathrm{t}$ (SNIS, 2006), e a disposição em aterro sanitário de R $\$ 45,00 / t$ o valor total é de $\mathrm{R} \$ 117,00 /$ t. Considerando-se ainda que os ganhos ambientais e sociais assumam um valor de $50 \%$ deste total chega-se ao valor indicativo da coleta seletiva de $\mathrm{R} \$ 175,00 / \mathrm{t}$ como adequado.

${ }^{* * * *}$ Comitês Gestores, Fórum Lixo e Cidadania, Câmara Técnicas ou GTs de Resíduos em Conselhos de Meio Ambiente, Fóruns da Agenda 21. Efetividade: influencia na formulação das políticas públicas, monitoramento da implementação, articulação de apoios e parcerias.

${ }_{\star \star \star \star \star}$ Organizações de catadores (redes), entre secretarias municipais, setor público estadual ou federal, setor privado, organizações não governamentais, entidades representativas dos catadores. 
APÊNDICE 2- Indicadores de organizações de catadores modo de medição e tendências à sustentabilidade

\begin{tabular}{|c|c|c|c|c|c|}
\hline \multicolumn{6}{|c|}{ Indicadores de organizações de catadores } \\
\hline & & \multirow[b]{2}{*}{ Modo de medição } & \multicolumn{3}{|c|}{ Tendência à sustentabilidade } \\
\hline & & & $\begin{array}{l}\text { Muito } \\
\text { Favorável }\end{array}$ & Favorável & Desfavorável \\
\hline 1 & $\begin{array}{l}\text { Renda média mensal } \\
\text { membro }\end{array}$ & $\begin{array}{l}\text { Renda média mensal por membro, últimos } \\
6 \text { meses em relação ao valor do salário mínimo }\end{array}$ & $\begin{array}{l}\geq 2 \text { salários } \\
\text { mínimos }\end{array}$ & $\begin{array}{l}\text { De } 1 \text { a } 2 \text { dois } \\
\text { s.m. }\end{array}$ & $\begin{array}{l}\leq 1 \text { salário } \\
\text { mínimo }\end{array}$ \\
\hline 2 & $\begin{array}{l}\text { Atendimento aos requisitos } \\
\text { de segurança e salubridade }\end{array}$ & $\frac{\text { N. de requisitos atendidos }}{\text { N. de requisitos desejáveis }} \times 100$ & $\geq 80 \%$ & $50,1 \%-79,9 \%$ & $\leq 50 \%$ \\
\hline 3 & $\begin{array}{l}\text { Uso de equipamentos de } \\
\text { proteção individual }\end{array}$ & $\frac{\text { N. membros que usam EPIs }}{\text { N. total de membros }}$ & $\geq 80 \%$ & $50,1 \%-79,9 \%$ & $\leq 50 \%$ \\
\hline 4 & $\begin{array}{l}\text { Participação dos membros } \\
\text { em reuniões }\end{array}$ & $\frac{\text { N. membros que participaram das reuniões }}{\text { N. total de membros } \times \text { N. de reuniões }} \times 100$ & $\geq 80 \%$ & $50,1 \%-79,9 \%$ & $\leq 50 \%$ \\
\hline 5 & Capacitação dos membros & $\frac{\text { N. atual de membros capacitados }}{N . \text { total atual de membros }} \times 100$ & $\geq 80 \%$ & $50,1 \%-79,9 \%$ & $\leq 50 \%$ \\
\hline 6 & Produtividade catador/mês & $\begin{array}{l}\frac{\text { Quantidade mensal de toneladas triadas }}{\mathrm{N} \text {. de catadores }} \quad \text { média últimos } 6 \text { meses. }\end{array}$ & $\geq 2$ t/mês & 1,1 - 1,9 t/ mês & $\leq 1 \mathrm{t} /$ mês \\
\hline 7 & $\begin{array}{l}\text { Regularização da } \\
\text { organização }\end{array}$ & $\frac{\text { N. de requisitos obrigatórios atendidos }}{N . \text { total de requisitos obrigatórios } * *} \times 100$ & $100 \%$ & $50,1 \%-99,9 \%$ & $\leq 50 \%$ \\
\hline 8 & $\begin{array}{l}\text { Atendimento aos requisitos } \\
\text { de saúde no trabalho }\end{array}$ & $\frac{N . \text { de requisitos atendidos }}{\text { N. de requisitos desejáveis }}{ }^{* * *} \times 100$ & $\geq 80 \%$ & $50,1 \%-79,9 \%$ & $\leq 50 \%$ \\
\hline 9 & $\begin{array}{l}\text { Instrumentos legais na } \\
\text { relação com a prefeitura }\end{array}$ & 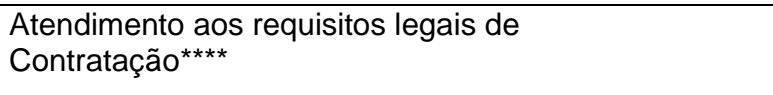 & $\geq 80 \%$ & $50,1 \%-79,9 \%$ & $\leq 50 \%$ \\
\hline 10 & $\begin{array}{l}\text { Atendimento aos requisitos } \\
\text { de autogestão }\end{array}$ & $\frac{\text { N. de requisitos atendidos }}{\text { N. de requisitos desejáveis }} \times 100$ & $\geq 80 \%$ & $50,1 \%-79,9 \%$ & $\leq 50 \%$ \\
\hline 11 & $\begin{array}{l}\text { Horas trabalhadas } \\
\text { membro/ total da organiz. }\end{array}$ & $\begin{array}{l}\text { N. de horas trabalhadas pelos membros } \times 100 \\
\text { N.de horas de trabalho da organização } \times \text { n. membros } \\
\text { (referência CLT e média dos últimos } 6 \text { meses) }\end{array}$ & $80 \%-100 \%$ & $50,1 \%-79,9 \%$ & $\begin{array}{l}\leq 50 \% \\
\geq 100 \%\end{array}$ \\
\hline 12 & Rotatividade dos membros & $\frac{\mathrm{N} . \text { atual de membros }}{\mathrm{N} \text {. total de membros }} \times 100 \quad$ média últimos 6 meses & $\geq 25 \%$ & $24,9 \%-49,9 \%$ & $\leq 50 \%$ \\
\hline 13 & Benefícios & $\frac{N \text { de benefícios efetivados } \times 100}{\text { N. de benefícios desejáveis }}{ }^{* * * * *}$ & $\geq 80 \%$ & $50,1 \%-79,9 \%$ & $\leq 50 \%$ \\
\hline 14 & $\begin{array}{l}\text { Relação de ganhos entre } \\
\text { gêneros por atividade }\end{array}$ & $\begin{array}{l}\text { Ganho do gênero feminino por hora }(\mathrm{R} \$) \times 100 \\
\text { Ganho do gênero masculino por hora }(\mathrm{R} \$)\end{array}$ & $100 \%$ & $70,1 \%-99,9 \%$ & $\leq 70 \%$ \\
\hline
\end{tabular}




\begin{tabular}{|c|c|c|c|c|c|}
\hline \multicolumn{6}{|c|}{ Continuação: Indicadores das organizações de catadores } \\
\hline & & \multirow[b]{2}{*}{ Modo de medição } & \multicolumn{3}{|c|}{ Tendência à sustentabilidade } \\
\hline & & & $\begin{array}{c}\text { Muito } \\
\text { Favorável }\end{array}$ & Favorável & Desfavorável \\
\hline 15 & $\begin{array}{l}\text { Equipamentos e veículos } \\
\text { próprios/edidos }\end{array}$ & $\frac{N . \text { de veículos e equipamentos próprios }}{N \text { N. total de veículos e equipamentos }} \times 100$ & $\geq 80 \%$ & $50,1 \%-79,9 \%$ & $\leq 50 \%$ \\
\hline 16 & $\begin{array}{l}\text { Diversificação das } \\
\text { atividades e serviços }\end{array}$ & $\frac{\text { N. de atividades e serviços }}{\text { N. total de atividades desejáveis }} \times 100$ & $\geq 80 \%$ & $50,1 \%-79,9 \%$ & $\leq 50 \%$ \\
\hline 17 & $\begin{array}{l}\text { Percentual de qualidade } \\
\text { das parcerias }\end{array}$ & $\frac{\text { N. parcerias efetivadas }}{\text { N. parcerias desejáveis }}{ }^{* \star * \star * \star *} \times 100$ & $\geq 80 \%$ & $50,1 \%-79,9 \%$ & $\leq 50 \%$ \\
\hline 18 & $\begin{array}{l}\text { Percentual de } \\
\text { diversificação das parcerias }\end{array}$ & $\frac{\text { N. de parcerias efetivadas }}{\text { N. de parcerias desejáveis }} \times 100$ & $\geq 80 \%$ & $50,1 \%-79,9 \%$ & $\leq 50 \%$ \\
\hline
\end{tabular}

* Rotina de limpeza, controle de vetores de doenças; ratos, moscas e barata, cobertura adequada, ventilação adequada, ausência de odores incômodos, sistema de prevenção de acidentes e incêndios.

** Cooperativa -Estatuto Social, Cadastro Nacional de Pessoa Jurídica- CNPJ, Registro na OCE, Atas de Assembléias gerais, diretoria funcionando, recolhimento de impostos, recolhimento de Fundos obrigatórios (FAT - 5\% e Fundo de Reserva - 10\%), livros em dia, emissão de notas fiscais, balanço anual. Associação- Estatuto Social, Cadastro Nacional de Pessoa Jurídica- CNPJ, Certidão Negativa do INSS, Certidão Negativa do FGTS, Certidão Negativa da Receita Federal, Livro de Matrícula dos Associados atualizado, últimas 3 (três) atas da Associação e Balancetes, ata de aprovação de contas do último exercício social.

*** Vacinação regular, prevenção de lesão por esforços repetitivos, descanso pelo peso das atividades, limpeza e higiene no local de trabalho, exames médicos periódicos, comunicação visual nos ambiente, recolhimento de INSS pelos cooperados, prevenção, registro e atendimento aos acidentes de trabalho.

**** Regularização, certidões Negativa do INSS, FGTS, Receita Federal e alvará municipal de funcionamento.

***** Reuniões de decisão auto-gestionária, regimento interno, instrumentos de transparência e rateio: informações sobre despesas, descontos, vendas e rateio, livros disponíveis, murais de comunicação e informação.

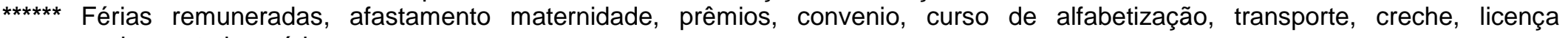
remunerada, conta bancária.

.${ }^{* * * * * *}$ Educação ambiental, coleta, triagem, beneficiamento, reaproveitamento de materiais recicláveis, reciclagem, prestação de serviços a terceiros.

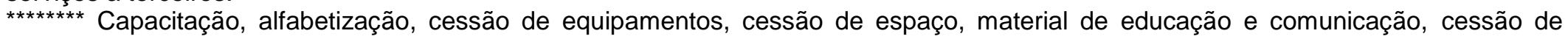
materiais recicláveis, ações de educação e comunicação, apoio técnico, construção de galpão de triagem.

${ }_{* \star \star \star * \star * \star \star}$ Outras organizações de catadores (redes), setor público estadual ou federal, setor privado, organizações não governamentais, organizações comunitárias, entidades representativas dos catadores. 


\section{APÊNDICE P}

Avaliação de Indicadores de sustentabilidade por organizações de catadores, $8^{\circ}$ Festival Lixo e Cidadania, Belo Horizonte, 2009.

Apêndice 1 - Avaliação de Indicadores de sustentabilidade de organizações de catadores

\begin{tabular}{|c|c|c|}
\hline \multicolumn{3}{|c|}{$\begin{array}{l}\text { INDICADORES DE SUSTENTABILIDADE } \\
\text { ORGANIZAÇÕES DE CATADORES }\end{array}$} \\
\hline Indicadores & Avaliação & Ressalvas e/ou observações \\
\hline Ind.1. Regularização & A & \\
\hline Ind. 2 Instrumentos legais & A & \\
\hline $\begin{array}{l}\text { Ind.3. Qualidade das } \\
\text { parcerias }\end{array}$ & AR & $\begin{array}{l}\text { A parceria é importante, mas é preciso } \\
\text { definir melhor o que é um parceiro. }\end{array}$ \\
\hline $\begin{array}{l}\text { Ind. 4. Diversificação de } \\
\text { parcerias }\end{array}$ & $A$ & $\begin{array}{l}\text { - Quanto mais diversificadas melhor. } \\
\text {-Existem parcerias pontuais, com } \\
\text { organizações de catadores, educação, } \\
\text { formação, cessão de espaços, saúde e } \\
\text { segurança do trabalho. }\end{array}$ \\
\hline $\begin{array}{l}\text { Ind.5. Diversificação das } \\
\text { atividades e serviços }\end{array}$ & A & $\begin{array}{l}\text { Muito importante para aumentar a } \\
\text { renda e não depender de uma única } \\
\text { atividade }\end{array}$ \\
\hline $\begin{array}{l}\text { Ind. } 6 . \text { Atendimento aos } \\
\text { requisitos de autogestão }\end{array}$ & $A$ & $\begin{array}{l}\text { Autonomia, não aceitar ingerência do } \\
\text { poder público. Autogestão sem assumir } \\
\text { o papel do governo. }\end{array}$ \\
\hline $\begin{array}{l}\text { Ind. 7. Participação dos } \\
\text { membros em reuniões auto- } \\
\text { gestionárias }\end{array}$ & A & Considerado muito importante \\
\hline $\begin{array}{l}\text { Ind. } 8 \text {. Membros capacitados } \\
\text { em relação ao total }\end{array}$ & A & Considerado muito importante \\
\hline Ind. 9. Rotatividade & AR & $\begin{array}{l}\text {-Quem não têm outras alternativas fica, } \\
\text { e os desempregados saem. Pode ser } \\
\text { bom ou ruim. } \\
\text {-A rotatividade se dá por vários fatores } \\
\text { e às vezes é bom que certas pessoas } \\
\text { não fiquem. }\end{array}$ \\
\hline
\end{tabular}




\begin{tabular}{|c|c|c|}
\hline \multicolumn{3}{|c|}{$\begin{array}{l}\text { Continuação: INDICADORES DE SUSTENTABILIDADE ORGANIZAÇÕES DE } \\
\text { CATADORES }\end{array}$} \\
\hline Indicadores & Avaliação & Ressalvas e/ou observações \\
\hline Ind. 10. Benefícios & A & Quanto mais melhor \\
\hline Ind. 11. Renda média & $A$ & Considerado muito importante \\
\hline $\begin{array}{l}\text { Ind. 12. Eficiência média da } \\
\text { produtividade por catador }\end{array}$ & A & Muito importante \\
\hline $\begin{array}{l}\text { Ind. 13. Equipamentos e } \\
\text { veículos próprios }\end{array}$ & A & \\
\hline Ind. 14. Horas trabalhadas & AR & $\begin{array}{l}\text { Aprovado desde que no máximo } 8 \\
\text { horas. }\end{array}$ \\
\hline $\begin{array}{l}\text { Ind. 15. Relação de ganhos } \\
\text { entre gêneros }\end{array}$ & $\mathrm{R}$ & $\begin{array}{l}\text { Acontece em muito poucas, portanto } \\
\text { não é um indicador importante. }\end{array}$ \\
\hline Ind. 16. Saúde no trabalho. & AR & Juntar tudo no indicador 17 \\
\hline $\begin{array}{l}\text { Ind. 17. Segurança e } \\
\text { salubridade do ambiente de } \\
\text { trabalho }\end{array}$ & A & Um dos indicadores mais importantes \\
\hline $\begin{array}{l}\text { Ind. 18. Uso de } \\
\text { equipamentos de proteção } \\
\text { individual - EPIS }\end{array}$ & AR & $\begin{array}{l}\text { Considerado incluído no indicador } \\
\text { anterior }\end{array}$ \\
\hline
\end{tabular}

Notas: Aprovado - A, Aprovado com ressalvas - AR, e Reprovado 
Apêndice 2 - Avaliação de Indicadores de sustentabilidade de coleta seletiva

\begin{tabular}{|c|c|c|}
\hline \multicolumn{3}{|c|}{ INDICADORES DE SUSTENTABILIDADE DE COLETA SELETIVA } \\
\hline & Avaliação & Ressalvas e/ou complementações \\
\hline $\begin{array}{l}\text { Ind. } 1 \text { Cobertura da } \\
\text { coleta seletiva. }\end{array}$ & A & $\begin{array}{l}1 \text { e } 2 \text { são muito importantes e se pode } \\
\text { combinar os dois. }\end{array}$ \\
\hline $\begin{array}{l}\text { Ind.2 Adesão da } \\
\text { população. }\end{array}$ & A & $\begin{array}{l}\text { A adesão também mede a educação } \\
\text { ambiental e a informação. Edução } \\
\text { socioambiental é fundamental. }\end{array}$ \\
\hline $\begin{array}{l}\text { Ind. } 3 \text { Parcerias do } \\
\text { Programa }\end{array}$ & $\overline{A R}$ & $\begin{array}{l}\text { A parceria é importante, mas é preciso } \\
\text { definir melhor, inclusive o que é um } \\
\text { parceiro. A parceria da prefeitura interfere } \\
\text { mais do que a parceria privada. }\end{array}$ \\
\hline $\begin{array}{l}\text { Ind. } 4 \text { Educação e } \\
\text { divulgação. }\end{array}$ & $\mathrm{R}$ & $\begin{array}{l}\text { O que mede a educação ambiental é } \\
\text { adesão da população. }\end{array}$ \\
\hline $\begin{array}{l}\text { Ind.5 Implementação } \\
\text { da gestão } \\
\text { compartilhada com a } \\
\text { sociedade civil }\end{array}$ & AR & $\begin{array}{l}\text { Não basta existir, tem que funcionar. } \\
\text { Sugestão existência e efetividade dos } \\
\text { canais de comunicação. }\end{array}$ \\
\hline $\begin{array}{l}\text { Ind. } 6 \text { Inclusão de } \\
\text { catadores avulsos. }\end{array}$ & A & $\begin{array}{l}\text { Considerado muito importante. } \\
\text { Este indicador também deveria ser } \\
\text { considerado para as organizações. }\end{array}$ \\
\hline $\begin{array}{l}\text { Ind. } 7 \text { linstrumentos } \\
\text { legais na relação com } \\
\text { as org.de catadores }\end{array}$ & A & Considerado muito importante \\
\hline $\begin{array}{l}\text { Ind. } 8 \text { Taxa de } \\
\text { recuperação de } \\
\text { materiais recicláveis - } \\
\text { TRMR. }\end{array}$ & AR & $\begin{array}{l}\text { O cálculo precisa também considerar } 0 \\
\text { volume além do peso, pois o caminhão dá } \\
\text { mais viagens, e também precisa calcular o } \\
\text { espaço economizado no aterro. }\end{array}$ \\
\hline Ind. 9 Taxa de rejeito & A & $\begin{array}{l}\text { Precisa definir rejeito, pode ser material não } \\
\text { reciclável e sem mercado. } \\
\text { Este indicador também deveria ser } \\
\text { considerado para as organizações }\end{array}$ \\
\hline $\begin{array}{l}\text { Ind. } 10 \text { Adequação das } \\
\text { condições de trabalho } \\
\text { na central de triagem. }\end{array}$ & A & $\begin{array}{l}\text { É importante ter uma listagem: espaço, } \\
\text { equipamentos, e de segurança e } \\
\text { manutenção, água, sanitários, cozinha, } \\
\text { refeitório, limpeza, higienização, proteção } \\
\text { de incêndios, bancada. }\end{array}$ \\
\hline
\end{tabular}




\section{APÊNDICE Q}

Avaliação de indicadores de sustentabilidade de coleta seletiva, por técnicos municipais da SLU, Belo Horizonte, em 2009.

Apêndice 1 - Avaliação de indicadores de sustentabilidade de coleta seletiva

\begin{tabular}{|c|c|c|}
\hline \multicolumn{3}{|c|}{ INDICADORES DE SUSTENTABILIDADE DE COLETA SELETIVA } \\
\hline Indicadores & Avaliação & Ressalvas e/ou complementações \\
\hline 1. Cobertura & A & Proposta de alta sustentabilidade - $90 \%$ a $100 \%$. \\
\hline $\begin{array}{l}\text { 2. Adesão da } \\
\text { população }\end{array}$ & A & $\frac{\text { Q.(peso) de resíduos recicláveis coletados }}{\text { Q.(peso) estimados (análise gravimétrica) }} \times 100$ \\
\hline 3. Parcerias & AR & $\begin{array}{l}\text { Construir um indice a partir de indicadores de cada } \\
\text { parceiro, que possibilite a ponderação da } \\
\text { importância da parceria para o programa. }\end{array}$ \\
\hline $\begin{array}{l}\text { 4. Educação e } \\
\text { divulqacão }\end{array}$ & $\mathrm{R}$ & $\begin{array}{l}\text { Indicador de Adesão e de rejeito mede educação } \\
\text { ambiental. }\end{array}$ \\
\hline $\begin{array}{l}\text { 5. Gestão } \\
\text { compartilhada }\end{array}$ & AR & $\begin{array}{l}\text { - Para municípios com mais de um canal, criar um } \\
\text { índice de avaliação da efetividade. } \\
\text { - Complementar medidas de efetividade: a) } \\
\text { influencia na formulação das políticas públicas, b) } \\
\text { monitoramento da implementação, c) articulação } \\
\text { de apoios e parcerias, d) paridade da } \\
\text { representação dos atores sociais, e) regularidade } \\
\text { das reunióes e da participação. } \\
\text { - Alterar tendências à sustentabilidade - Existe e } \\
\text { funciona- acima de ou igual a } 61 \% \text { das metas, } \\
\text { Média - existe, mas não funciona- de } 30 \% \text { a } 60 \% \\
\text { das metas }\end{array}$ \\
\hline $\begin{array}{l}\text { 6. Inclusão de } \\
\text { catadores } \\
\text { avulsos }\end{array}$ & AR & $\frac{N \text { de catadores avulsos incluídos em org. do programa }}{N \text {. de catadores avulsos estabelecidos como meta }} \times 100$ \\
\hline $\begin{array}{l}\text { 7. Instrumentos } \\
\text { legais }\end{array}$ & A & \\
\hline
\end{tabular}




\begin{tabular}{|c|c|c|}
\hline Indicadores & Avaliação & Ressalvas e/ou complementações \\
\hline 8. TRMR & A & \\
\hline 9. Taxa de rejeito - & A & \\
\hline $\begin{array}{l}\text { 10. Adequação das } \\
\text { condições de } \\
\text { trabalho na central } \\
\text { de triagem }\end{array}$ & AR & $\begin{array}{l}\text { - Construir um índice com os diferentes itens de } \\
\text { acordo com os critérios da Norma do Ministério } \\
\text { do Trabalho - Portaria } 3214 / 78 \text { NR } 24 \text {, e incluir } \\
\text { ergonomia. } \\
\text { - Alterar tendência à sustentabilidade -Média } \\
50,1 \% \text { a } 79,9 \%\end{array}$ \\
\hline $\begin{array}{l}11 . \\
\text { Autofinanciamento }\end{array}$ & A & $\frac{\text { Recursos do IPTU e/ou de taxa (destinados) }(\mathrm{R} \$) \times 100}{\text { Custo do programa }(\mathrm{R} \$)}$ \\
\hline $\begin{array}{l}\text { 12. Custo do } \\
\text { programa / custo do } \\
\text { manejo de resíduos } \\
\text { sólidos. }\end{array}$ & A & $\begin{array}{l}\text { Alterar tendências à sustentabilidade: } \\
\text { Alta- } \leq 30 \% \text {. Média }-29,9 \text { a } 59,9 \% \text { e Baixa- } \geq \\
60 \% \text {. }\end{array}$ \\
\hline $\begin{array}{l}\text { 13. Custo do } \\
\text { programa/ } \\
\text { quantidade coleta } \\
\text { seletiva }\end{array}$ & A & $\begin{array}{l}\text { Alterar tendências; Alta- até duas vezes o custo } \\
\text { da coleta convencional, Média - Entre } 2,1 \text { e } 4,9 \\
\text { vezes o custo da coleta convencional e Baixa - } \\
\text { mais de } 5 \text { vezes o custo da coleta convencional }\end{array}$ \\
\hline $\begin{array}{l}\text { 14. Custo da coleta } \\
\text { seletiva/ coleta } \\
\text { domiciliar }+ \\
\text { aterramento }\end{array}$ & A & $\begin{array}{l}\text { - Transformar em custo unitário na fórmula } \\
\text { Tendência à sustentabilidade -Alta- Coleta } \\
\text { seletiva =convencional +aterramento }=1 \text {, Média } \\
\text { - entre } 1,1 \text { e } 4,9 \text { vezes o custo da coleta } \\
\text { convencional e Baixa - Mais de } 5 \text { vezes o custo } \\
\text { da coleta convencional + aterramento }\end{array}$ \\
\hline
\end{tabular}

Notas: A - aprovado $\quad$ AR - aprovado com ressalvas $\quad R$ - reprovado 
Apêndice 2 - Avaliação de indicadores de organizações de catadores

\begin{tabular}{|c|c|c|}
\hline \multicolumn{3}{|c|}{ INDICADORES DE SUSTENTABILIDADE DE ORGANIZAÇÕES DE CATADORES } \\
\hline INDICADORES & Avaliação & Ressalvas e/ou complementações \\
\hline Ind.1 Regularização & A & $\begin{array}{l}\text { Incluir Registro na Junta Comercial do } \\
\text { Estado para cooperativas }\end{array}$ \\
\hline Ind. 2 Instrumentos legais & A & \\
\hline Ind.3. Qualidade das parcerias & AR & Construir índice \\
\hline $\begin{array}{l}\text { Ind. Diversificação de } \\
\text { parcerias }\end{array}$ & AR & Construir índice \\
\hline $\begin{array}{l}\text { Ind.5. Diversificação das } \\
\text { atividades e serviços }\end{array}$ & A & \\
\hline $\begin{array}{l}\text { Ind. } 6 \text {. Atendimento aos } \\
\text { requisitos de autogestão }\end{array}$ & A & Incluir rotatividade na direção \\
\hline $\begin{array}{l}\text { Ind. 7. Participação em } \\
\text { reuniões auto-gestionárias }\end{array}$ & A & \\
\hline Ind. 8. Capacitação & A & \\
\hline Ind. 9. Rotatividade & A & \\
\hline Ind. 10. Benefícios & A & Incluir curso de capacitação. \\
\hline Ind. 11. Renda média & A & \\
\hline $\begin{array}{l}\text { Ind. 12. Eficiência média da } \\
\text { produtividade por catador }\end{array}$ & A & \\
\hline $\begin{array}{l}\text { Ind. 13. Equipamentos e } \\
\text { veículos próprios }\end{array}$ & A & \\
\hline Ind. 14. Horas trabalhadas & AR & \\
\hline Ind. 15. Ganhos entre gêneros & A & \\
\hline Ind. 16. Saúde no trabalho. & A & $\begin{array}{l}\text { Incluir índice de dependência de } \\
\text { medicamentos álcool, drogas e saúde } \\
\text { mental. }\end{array}$ \\
\hline $\begin{array}{l}\text { Ind. 17. Segurança e } \\
\text { salubridade }\end{array}$ & A & $\begin{array}{l}\text { Incluir existência de sistema } \\
\text { capacitação para prevenção de } \\
\text { incêndios e treinamento de primeiros } \\
\text { socorros. }\end{array}$ \\
\hline Ind. 18. Uso de EPIs & A & \\
\hline
\end{tabular}

Notas: A - aprovado $\quad$ AR - aprovado com ressalvas $\quad R$ - reprovado. 


\section{APENDICE R}

Avaliação de indicadores de sustentabilidade, por técnicos do INSEA, Belo Horizonte, 2010.

Apêndice 1 - Avaliação de indicadores de sustentabilidade de coleta seletiva

\begin{tabular}{|c|c|c|}
\hline \multicolumn{3}{|c|}{ INDICADORES DE SUSTENTABILIDADE DE COLETA SELETIVA } \\
\hline & Avaliação & Ressalvas e/ou complementações \\
\hline 1. Cobertura & A & $\begin{array}{l}\text { Alterar tendência à sustentabilidade: Alta para } \\
70,1 \text { a } 100 \% \text {, média } 30,1 \% \text { a } 70,0 \% \text {, baixa } \leq \\
30 \%\end{array}$ \\
\hline $\begin{array}{l}\text { 2. Adesão da } \\
\text { população }\end{array}$ & A & $\begin{array}{l}\text { Aprovadas as duas fórmulas, em residências } \\
\text { para municípios de pequeno porte e por peso } \\
\text { em municípios de grande porte. Precisa verificar } \\
\text { se dá para comparar. }\end{array}$ \\
\hline 3. Parcerias & AR & $\begin{array}{l}\text { n. de parcerias identificadas } \\
\text { n. de parcerias firmadas } \\
\text { - Poderia ser um índice por área: econômica, } \\
\text { social e institucional }\end{array}$ \\
\hline $\begin{array}{l}\text { 4. Educação e } \\
\text { divulgação }\end{array}$ & $\mathrm{R}$ & $\begin{array}{l}\text { - Substituir por outro indicador de que não seja } \\
\text { por freqüência, mas de eficiência. } \\
\text { - Relação adesão e índice de rejeito pode ser } \\
\text { uma forma de medir }\end{array}$ \\
\hline $\begin{array}{l}\text { 5. Gestão } \\
\text { compartilhada }\end{array}$ & AR & $\begin{array}{l}\text { É preciso aprofundar a questão se é gestão } \\
\text { compartilhada ou co-gestão pelos catadores. } \\
\text {-Alterar tendência à sustentabilidade Alta: existe } \\
\text { e funciona- maior ou igual a } 61 \% \text { das metas, } \\
\text { média; existe, mas não funciona- entre } 30 \% \text { e } \\
60 \% \text { das metas. }\end{array}$ \\
\hline $\begin{array}{l}\text { 6. Inclusão de } \\
\text { catadores avulsos }\end{array}$ & AR & $\begin{array}{l}\text {-Complementar - no programa de coleta seletiva } \\
\text { de acordo com as metas estabelecidas. } \\
\text { - É necessário entender melhor a relação entre } \\
\text { os catadores avulsos e os depósitos e respeitar } \\
\text { o processo. }\end{array}$ \\
\hline
\end{tabular}




\begin{tabular}{|c|c|c|}
\hline \multicolumn{3}{|c|}{ Continuação: INDICADORES DE SUSTENTABILIDADE DE COLETA SELETIVA } \\
\hline & Avaliação & Ressalvas e/ou complementações \\
\hline 7. Instrumentos legais & A & \\
\hline $\begin{array}{l}\text { 8. Taxa de } \\
\text { recuperação de } \\
\text { recicláveis - TRMR }\end{array}$ & A & \\
\hline 9. Taxa de rejeito - IR & A & \\
\hline $\begin{array}{l}\text { 10. Condições de } \\
\text { trabalho na central de } \\
\text { triagem }\end{array}$ & AR & $\begin{array}{l}\text { - Incluir infra- estrutura de trabalho: espaço de } \\
\text { estocagem e de trabalho, triagem, logística e } \\
\text { fluxo - critérios do Manual do Ministério. } \\
\text { - Alterar tendência à sustentabilidade média } \\
\text { para: } 50,1 \% \text { a } 79,9 \%\end{array}$ \\
\hline $\begin{array}{l}11 . \\
\text { Autofinanciamento }\end{array}$ & A & $\begin{array}{l}\text { O indicador foi aprovado, mas não ficou definido } \\
\text { se a fórmula foi aprovada }\end{array}$ \\
\hline $\begin{array}{l}\text { 12. Custo do } \\
\text { programa / custo do } \\
\text { manejo RS }\end{array}$ & A & $\begin{array}{l}\text { Alterar tendência à sustentabilidade média } \\
\text { para: } 29,9 \text { a } 59,9 \%\end{array}$ \\
\hline $\begin{array}{l}\text { 13. Custo do } \\
\text { programa/ quantidade } \\
\text { seletiva }\end{array}$ & A & $\begin{array}{l}\text { Alterar tendência à sustentabilidade média para: } \\
\text { entre } 2,1 \text { e } 4,9 \text { vezes o custo da coleta } \\
\text { convencional }\end{array}$ \\
\hline $\begin{array}{l}\text { 14. Custo da coleta } \\
\text { seletiva/ coleta } \\
\text { domiciliar + aterro }\end{array}$ & AR & $\begin{array}{l}\text {-Trocar aterramento por destinação final de } \\
\text { resíduos. } \\
\text {-Alterar tendência à sustentabilidade média } \\
\text { para: entre } 1,1 \text { e } 4,9 \text { vezes o custo da coleta } \\
\text { convencional }\end{array}$ \\
\hline
\end{tabular}

Notas: - A - aprovado, AR - aprovado com ressalvas e $\mathrm{R}$ - reprovado. 
Apêndice 2 - Avaliação de indicadores de sustentabilidade de organizações de catadores, por técnicos do INSEA, Belo Horizonte, 2010

\begin{tabular}{|c|c|c|}
\hline \multicolumn{3}{|c|}{ INDICADORES DE SUSTENTABILIDADE DE ORGANIZAÇÕES DE CATADORES } \\
\hline Indicadores & Avaliação & Ressalvas e/ou complementações \\
\hline Ind.1 Regularização & AR & $\begin{array}{l}\text { Na Associação incluir Registro na Junta } \\
\text { Comercial do Estado e Livro ou Ficha }\end{array}$ \\
\hline $\begin{array}{l}\text { Ind. } 2 \text { Instrumentos legais na } \\
\text { parceria com a prefeitura }\end{array}$ & AR & $\begin{array}{l}\text { - Alterar nome do Indicador; na relação } \\
\text { com a prefeitura, no lugar de parceria. } \\
\text { - Alterar tendência :Alta - Contrato ou } \\
\text { convenio com remuneração pelo } \\
\text { serviço prestado média, Média- } \\
\text { Convenio sem remuneração pelo } \\
\text { serviço prestado, }\end{array}$ \\
\hline $\begin{array}{l}\text { Ind.3. Qualidade das } \\
\text { parcerias }\end{array}$ & AR & Incluir Assessoria Técnica \\
\hline $\begin{array}{l}\text { Ind. Diversificação de } \\
\text { parcerias }\end{array}$ & AR & $\begin{array}{l}\text {-Incluir Poder legislativo e Ministério } \\
\text { Público e redes e centrais de } \\
\text { organizações de catadores } \\
\text {-Tendência à sustentabilidade- Alta } \\
70 \% \text { a } 100 \% \text {, média } 30,1 \% \text { a } 69,9 \% \\
\text { baixa } \leq 30 \%\end{array}$ \\
\hline Ind.5. Atividades e serviços & AR & Incluir comercialização \\
\hline $\begin{array}{l}\text { Ind. } 6 \text {. Atendimento aos } \\
\text { requisitos de autogestão }\end{array}$ & AR & $\begin{array}{l}\text { Incluir compartilhamento operacional e } \\
\text { administrativo, rotatividade na direção e } \\
\text { participação nas políticas públicas }\end{array}$ \\
\hline Ind. 7. Participação & A & \\
\hline $\begin{array}{l}\text { Ind. 8. Capacitação dos } \\
\text { membros }\end{array}$ & A & \\
\hline Ind. 9. Rotatividade & A & $\begin{array}{l}\text { N. de membros que saíram (últimos seis meses) } \times 100 \\
\text { Média de n. de membros (últimos } 6 \text { meses) }\end{array}$ \\
\hline Ind. 10. Benefícios & AR & $\begin{array}{l}\text { Incluir distribuição do recurso } \\
\text { excedente de sobras e alimentação e } \\
\text { retirar curso de capacitação. }\end{array}$ \\
\hline
\end{tabular}




\begin{tabular}{|c|c|c|}
\hline \multicolumn{3}{|c|}{ Continuação: INDICADORES DE SUSTENTABILIDADE DE ORGANIZAÇÕES DE CATADORES } \\
\hline Indicadores & Avaliação & Ressalvas e/ou complementações \\
\hline Ind. 11. Renda média & A & \\
\hline $\begin{array}{l}\text { Ind. 12. Eficiência média da } \\
\text { produtividade por catador }\end{array}$ & A & \\
\hline $\begin{array}{l}\text { Ind. 13. Equipamentos e } \\
\text { veículos próprios }\end{array}$ & $\mathrm{R}$ & $\begin{array}{l}\text { Retirar veículos e criar um indicador } \\
\text { de coleta. Incluir em boas condições } \\
\text { de uso. }\end{array}$ \\
\hline Ind. 14. Horas trabalhadas & $\mathrm{R}$ & \\
\hline $\begin{array}{l}\text { Ind. 15. Ganhos entre } \\
\text { gêneros }\end{array}$ & $\mathrm{R}$ & \\
\hline Ind. 16. Saúde no trabalho. & AR & $\begin{array}{ll}\text { Retirar alimentação adequada } & \text { e } \\
\text { melhorar os itens - consultar OIT. }\end{array}$ \\
\hline $\begin{array}{l}\text { Ind. } 17 \text {. Segurança e } \\
\text { salubridade do ambiente de } \\
\text { trabalho }\end{array}$ & AR & $\begin{array}{l}\text { - Incluir comunicação visual, cozinha, } \\
\text { sanitários, vestiário, existência de } \\
\text { sistema e capacitação (Brigada de } \\
\text { incêndio) para prevenção de } \\
\text { incêndios, treinamento de primeiros } \\
\text { socorros }\end{array}$ \\
\hline $\begin{array}{l}\text { Ind. 18. Uso de } \\
\text { equipamentos de proteção } \\
\text { individual - EPIS }\end{array}$ & A & \\
\hline
\end{tabular}

Notas: - A - aprovado, AR - aprovado com ressalvas e $\mathrm{R}$ - reprovado. 


\section{APÊNDICE S}

Renda média e quantidade de materiais recicláveis comercializados, em 2005 e 2010, variação percentual da taxa de recuperação de materiais recicláveis TRMR, número de membros e da renda média dos membros, em salários mínimos, em 13 municípios da RMSP, entre 2005 e 2010.

\begin{tabular}{|c|c|c|c|c|c|c|c|}
\hline \multirow{3}{*}{ Municípios } & \multicolumn{4}{|c|}{ Coleta seletiva } & \multicolumn{3}{|c|}{ Variação } \\
\hline & \multicolumn{2}{|c|}{$\begin{array}{l}\text { Renda média* } \\
\text { dos catadores }\end{array}$} & \multicolumn{2}{|c|}{$\begin{array}{c}\text { Quantidade média } \\
\text { de recicláveis } \\
\text { comercializada } \\
(\mathrm{t} / \mathrm{mês})\end{array}$} & \multirow{2}{*}{\begin{tabular}{|c|}
$\begin{array}{c}\text { Renda média * } \\
(\%)\end{array}$ \\
2005 a 2010 \\
\end{tabular}} & \multirow{2}{*}{\begin{tabular}{|c|}
$\begin{array}{c}\text { Quantidade média } \\
\text { de recicláveis } \\
\text { Comercializada } \\
\text { (\%) }\end{array}$ \\
2005 a 2010
\end{tabular}} & \multirow{2}{*}{\begin{tabular}{|c|c}
$\begin{array}{c}\text { N. de } \\
\text { membros } \\
(\%)\end{array}$ \\
2005 a 2010
\end{tabular}} \\
\hline & 2005 & 2010 & 2005 & 2010 & & & \\
\hline Barueri & 3,5 & 1,4 & 70,0 & 40,0 & -60 & 243 & 216 \\
\hline Diadema & 1,0 & 1,4 & 54,0 & 120,0 & 40 & 122 & 75 \\
\hline Embu & 2,3 & 0,9 & 52,0 & 110,0 & -61 & 111 & 87 \\
\hline Itapecerica S. & 0,5 & 1,0 & 28,5 & 70,0 & 100 & 146 & 150 \\
\hline Itapevi & -- & 1,0 & 10,0 & 35,0 & -- & 250 & 0 \\
\hline Jandira & 1,1 & 0,9 & 3,0 & 70,0 & -18 & 2233 & 67 \\
\hline Mauá & -- & 0,9 & 11,0 & 40,0 & -- & 264 & 0 \\
\hline Poá & 1,0 & 0,9 & 23,0 & 47,0 & -10 & 104 & 17 \\
\hline Ribeirão Pires & -- & 0,8 & 5,0 & 37,0 & -- & 640 & 11 \\
\hline $\begin{array}{c}\text { Santana de } \\
\text { Parnaíba }\end{array}$ & 1,9 & 1,6 & 45,0 & 300,0 & -16 & 567 & 77 \\
\hline Santo André & 1,3 & 1,0 & 500,0 & 630,0 & -23 & 26 & 36 \\
\hline S. Bernardo C. & 2,0 & 2,0 & 88,0 & 364,0 & 0 & 314 & 56 \\
\hline São Paulo & 2,0 & 1,4 & $1.670,0$ & 135,0 & -30 & 88 & 58 \\
\hline
\end{tabular}

*Em relação ao salário mínimo por membro da organização.

Elaborado pela autora com dados de RIBEIRO et al., 2009 e dados das prefeituras municipais, em março de 2010. 


\section{APÊNDICE T}

Indicadores de sustentabilidade de coleta seletiva e de organizações catadores, e respectivas medianas e médias, na $2^{\underline{a}}$ Rodada do Delphi

Apêndice 1 - Indicadores de sustentabilidade da coleta seletiva

\begin{tabular}{|l|c|c|}
\hline Indicadores da coleta seletiva & Mediana & Média \\
\hline 1. Percentual de atendimento da população & 10,0 & 9,0 \\
\hline 2. Percentual de adesão da população. & 10,0 & 9,1 \\
\hline 3. Percentual de Parcerias do Programa & 7,0 & 6,2 \\
\hline 4. Freqüência de programa de educação e divulgação & 8,0 & 7,9 \\
\hline 5. Gestão compartilhada com a sociedade civil & 8,0 & 7,3 \\
\hline 6. Percentual de inclusão de catadores avulsos. & 8,0 & 7,4 \\
\hline 7. Implementação de instrumentos legais & 9,0 & 8,3 \\
\hline 8. Taxa de recuperação de materiais recicláveis & 9,0 & 8,9 \\
\hline 9. Taxa de Rejeito & 9,0 & 8,7 \\
\hline 10. Percentual de adequação das condições de trabalho & 9,0 & 8,4 \\
\hline 11. Percentual de auto-financiamento do programa. & 8,0 & 8,0 \\
\hline $\begin{array}{l}\text { 12. Percentual do custo do programa em relação ao custo do } \\
\text { manejo }\end{array}$ & 8,0 & 7,8 \\
\hline 13. Custo do programa em relação à coletada seletiva & 9,0 & 8,2 \\
\hline $\begin{array}{l}\text { 14. Custo da coleta seletiva em relação à coleta regular e } \\
\text { aterramento }\end{array}$ & 8,5 & 8,1 \\
\hline
\end{tabular}

Elaborado pela autora com dados da $2^{\underline{a}}$ rodada do Delphi. 


\section{Apêndice 2}

Indicadores de sustentabilidade de organizações de catadores e respectivas medianas e médias - 2 ${ }^{\mathrm{a}}$ Rodada do Delphi

\begin{tabular}{|c|c|c|}
\hline Indicadores das organizações de catadores & Mediana & Média \\
\hline $\begin{array}{l}\text { 1. } \\
\text { Percentual de atendimento aos requisitos de } \\
\text { regularização }\end{array}$ & 9,0 & 8,4 \\
\hline 2. Instrumentos legais da parceria com a prefeitura & 8,0 & 8,4 \\
\hline 3. $\quad$ Percentual de qualidade das parcerias & 8,0 & 7,1 \\
\hline 4. Percentual de diversificação de parcerias & 7,0 & 6,6 \\
\hline 5. $\quad$ Percentual de diversificação das atividades e serviços & 8,0 & 7,4 \\
\hline 6. Percentual de atendimento aos requisitos de autogestão & 8,0 & 8,2 \\
\hline 7. $\quad$ Percentual de participação dos membros em reuniões & 9,0 & 8,6 \\
\hline 8. Percentual de membros capacitados em relação ao total & 9,0 & 8,4 \\
\hline 9. $\quad$ Percentual de rotatividade dos membros & 8,0 & 8,0 \\
\hline 10. Percentual de benefícios proporcionados aos membros & 8,0 & 7,9 \\
\hline 11. Renda média mensal por membro & 10,0 & 9,5 \\
\hline 12. Eficiência média da produtividade (t/catador /mês) & 9,0 & 8,4 \\
\hline 13. Percentual de equipamentos e veículos & 8,0 & 7,4 \\
\hline 14. Percentual de horas trabalhadas/ horas organização & 8,0 & 7,7 \\
\hline $\begin{array}{l}\text { 15. Percentual de relação de ganhos entre gêneros/ hora/ } \\
\text { atividade }\end{array}$ & 8,0 & 7,4 \\
\hline $\begin{array}{l}\text { 16. Percentual de atendimento aos requisitos de saúde no } \\
\text { trabalho. }\end{array}$ & 9,5 & 8,7 \\
\hline $\begin{array}{l}\text { 17. Percentual de atendimento à segurança e salubridade do } \\
\text { trabalho }\end{array}$ & 10,0 & 8,9 \\
\hline 18. Percentual de membros que usam EPIs & 9,0 & 8,7 \\
\hline
\end{tabular}


ANEXO 1 - Índice da Coleta Seletiva - ICS da CETESB

\begin{tabular}{|c|c|c|c|c|c|}
\hline Item & Tópico & \multicolumn{2}{|l|}{ Descrição } & Pontos & \\
\hline \multirow{7}{*}{ 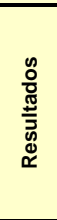 } & \multirow{6}{*}{ 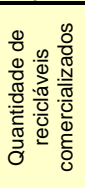 } & \multicolumn{2}{|c|}{ Quantidade total dos RSD coletados t/mês } & & \\
\hline & & \multicolumn{2}{|c|}{$\begin{array}{l}\text { Quantidade de recicláveis comercializada } \\
\text { t/mês }\end{array}$} & & \\
\hline & & \multicolumn{2}{|c|}{$\geq 30 \%$ do peso total de RSD } & 10 & \\
\hline & & \multicolumn{2}{|c|}{$<30$ a $20 \%$ do peso total de RSD } & 7 & \\
\hline & & \multicolumn{2}{|c|}{$<20$ a $10 \%$ do peso total de RSD } & 4 & \\
\hline & & \multicolumn{2}{|l|}{$<10$ a $1 \%$ do peso total de RSD } & 2 & \\
\hline & \multicolumn{3}{|c|}{ SubTotal Máximo A } & 10 & \\
\hline \multirow{13}{*}{ 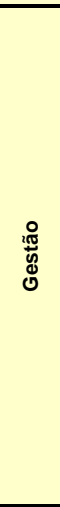 } & \multirow{5}{*}{ 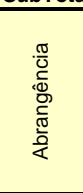 } & \multicolumn{2}{|c|}{ \% da População urbana atendida } & & \\
\hline & & \multirow{2}{*}{\multicolumn{2}{|c|}{$\begin{array}{l}\% \text { da Área urbana atendida } \\
100 \text { a } 75 \%\end{array}$}} & & \\
\hline & & & & $\frac{10}{6}$ & \\
\hline & & \multicolumn{2}{|l|}{$<50$ a $25 \%$} & 0 & \\
\hline & & \multicolumn{2}{|l|}{$<25$ a $1 \%$} & 2 & \\
\hline & & \multicolumn{2}{|c|}{$\begin{array}{l}\text { Porta a porta c/ veiculo, carrinheiros e/ou } \\
\text { carroceiros + PEVs }\end{array}$} & 10 & \\
\hline & $\frac{\pi}{0}$ & \multicolumn{2}{|c|}{$\begin{array}{l}\text { Porta a porta c/ veiculo carrinheiros e/ou } \\
\text { carroceiros }\end{array}$} & 9 & \\
\hline & $\frac{\Phi}{0}$ & \multicolumn{2}{|c|}{ Porta a Porta com veículo e PEVs } & 8 & \\
\hline & 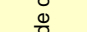 & \multicolumn{2}{|c|}{ Porta a Porta com veículo } & 7 & \\
\hline & $\stackrel{\circ}{\circ}$ & $\begin{array}{l}\text { Porta a Porta com carrinheiros } \\
\text { carroceiros }+ \text { PEVs }\end{array}$ & e/ou & 6 & \\
\hline & & $\begin{array}{l}\text { Porta a Porta com carrinheiro } \\
\text { carroceiros }\end{array}$ & e/ou & 5 & \\
\hline & & Pontos de entrega voluntária & PEVs & 3 & \\
\hline & SubTota & Máximo B & & 20 & 0 \\
\hline & & Propriedade municipal & & 3 & \\
\hline & & Outros & & 2 & \\
\hline & & Tipo de construção & Alvenaria & 3 & \\
\hline & & & Outro & 1 & \\
\hline & & Refeitório & Sim & 1 & \\
\hline & & & Não & 0 & \\
\hline & & Banheiro & Sim & 1 & \\
\hline & 음 & & Não & 0 & \\
\hline & $\underline{-2}$ & Isolamento visual & Sim & 1 & \\
\hline & i̊ి & & Não & 0 & \\
\hline & $\frac{0}{\pi}$ & Isolamento físico & Sim & 1 & \\
\hline & & & Não & 0 & \\
\hline & & Piso/Pátio impermeabilizado & Sim & 2 & \\
\hline E & & & Não & 0 & \\
\hline o & & Escritório & & & \\
\hline$\overline{\bar{c}}$ & & Balança & Sim & 1 & \\
\hline 8 & & & Não & 0 & \\
\hline 웅 & & Prensa enfardadeira & Sim & 2 & \\
\hline 宓 & & & Não & 0 & \\
\hline 竧 & & Sistema de separação & $\begin{array}{l}\text { Esteira de } \\
\text { separação }\end{array}$ & 2 & \\
\hline 递 & & & $\begin{array}{l}\text { Mesa de } \\
\text { separação }\end{array}$ & 1 & \\
\hline & $\frac{\frac{\pi}{\pi}}{\frac{\pi}{0}}$ & & Não tem & 0 & \\
\hline & $\frac{\tilde{\pi}}{\pi}$ & & Sim & 2 & \\
\hline & Oొ & Elevador de Carga & Não & 0 & \\
\hline & 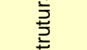 & Baia(s) de armazenagem de & Sim & 2 & \\
\hline & யొ & recicláveis & Não & 0 & \\
\hline & & Local adequado para & Sim & 2 & \\
\hline & & $\begin{array}{l}\text { recepção do material } \\
\text { coletado }\end{array}$ & Não & 0 & \\
\hline & & Local de armazenagem de & Sim & 1 & \\
\hline & & & Não & 0 & \\
\hline
\end{tabular}

\begin{tabular}{|c|c|c|c|c|c|}
\hline Item & Tópico & Descrição & & $\begin{array}{l}\text { Pont } \\
\text { os }\end{array}$ & \\
\hline \multirow{15}{*}{ 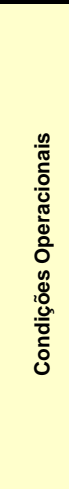 } & \multirow{10}{*}{ 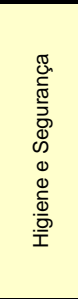 } & \multirow{2}{*}{$\begin{array}{l}\text { Possui e usa EPIs (Oculos, } \\
\text { luvas, botas, etc.) }\end{array}$} & Sim & 3 & \\
\hline & & & Não & 0 & \\
\hline & & \multirow[t]{2}{*}{ Uniforme } & Sim & 0 & \\
\hline & & & Não & 6 & \\
\hline & & Geração de fortes odores & Sim & 0 & \\
\hline & & & Não & 6 & \\
\hline & & Presença de vetores em & Sim & 0 & \\
\hline & & grande quantidade & Não & 6 & \\
\hline & & Presença de animais(Aves, & Sim & 0 & \\
\hline & & cães, porcos, etc) & Não & 6 & \\
\hline & \multirow{2}{*}{$\begin{array}{c}\text { Destino } \\
\text { dos } \\
\text { rejeitos }\end{array}$} & \multicolumn{2}{|c|}{ Aterro sanitário ou em valas - licenciado } & 9 & \\
\hline & & \multicolumn{2}{|l|}{ Outros } & 0 & \\
\hline & \multirow{2}{*}{$\begin{array}{l}\frac{\pi}{0} \\
\frac{0}{0} \\
>\end{array}$} & \multicolumn{2}{|l|}{ Direta } & 3 & \\
\hline & & \multicolumn{2}{|l|}{ Intermediários } & 1 & \\
\hline & \multicolumn{3}{|c|}{ SubTotal Máximo D } & 33 & 0 \\
\hline \multirow{11}{*}{ 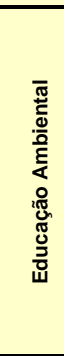 } & \multirow{10}{*}{$\begin{array}{l}\frac{0}{0} \\
\frac{\pi}{0} \\
\stackrel{0}{2} \\
\end{array}$} & \multirow{2}{*}{$\begin{array}{l}\text { Campanhas de informação } \\
\text { individuais e/ou coletivas }\end{array}$} & Sim & 6 & \\
\hline & & & Não & 0 & \\
\hline & & \multirow[t]{2}{*}{ Capacitação de agentes } & Sim & 5 & \\
\hline & & & Não & 0 & \\
\hline & & \multirow[t]{2}{*}{ Atividades dirigidas às escolas } & Sim & 6 & \\
\hline & & & Não & 0 & \\
\hline & & \multirow{2}{*}{$\begin{array}{l}\text { Realização de eventos de } \\
\text { incentivo à coleta seletiva }\end{array}$} & Sim & 5 & \\
\hline & & & Não & 0 & \\
\hline & & \multirow{2}{*}{$\begin{array}{l}\text { Distribuição de saquinhos } \\
\text { específicos para coleta seletiva }\end{array}$} & Sim & 2 & \\
\hline & & & Não & 0 & \\
\hline & \multicolumn{3}{|c|}{ SubTotal Máximo E } & 24 & 0 \\
\hline \multicolumn{5}{|c|}{ Nota Final $=\{[A \times 0,4]+[(B+C+D+E / 10,6) \times 0,6]\}$} & 1 \\
\hline Con & & \multicolumn{4}{|c|}{$\begin{array}{l}0 \text { a } 6,0 \text { - Inadequado - } 6,1 \text { a } 8,0 \text { Regular }-8,1 \text { a } 10- \\
\text { Adequado }\end{array}$} \\
\hline
\end{tabular}

\begin{tabular}{|c|c|c|c|c|}
\hline \multirow{21}{*}{ 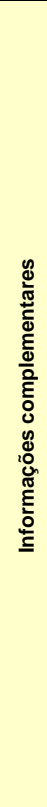 } & \multirow{3}{*}{$\begin{array}{l}\text { Mão de } \\
\text { obra da } \\
\text { triagem }\end{array}$} & \multicolumn{2}{|c|}{ Associados ou cooperados } & $\square$ \\
\hline & & \multicolumn{2}{|c|}{ Famílias } & $\square$ \\
\hline & & \multicolumn{3}{|l|}{ Outros } \\
\hline & \multirow{18}{*}{$\begin{array}{c}\text { Situação } \\
\text { Legal }\end{array}$} & \multirow{2}{*}{\multicolumn{2}{|c|}{$\begin{array}{l}\text { Há compromisso legal entre a associação } \\
\text { / cooperativa / família e a Prefeitura, por } \\
\text { concessão / contrato ou outro instrumento } \\
\text { legal? }\end{array}$}} & Sim \\
\hline & & & & Não \\
\hline & & & Ferrosos & t/mês \\
\hline & & \multicolumn{2}{|c|}{ Papel / Papelão } & t/mês \\
\hline & & \multirow[t]{6}{*}{ Plásticos } & PET & t/mês \\
\hline & & & PEAD & t/mês \\
\hline & & & PVC & t/mês \\
\hline & & & PEBD & t/mês \\
\hline & & & PP & t/mês \\
\hline & & & Outros & t/mês \\
\hline & & \multicolumn{2}{|c|}{ Vidros } & t/mês \\
\hline & & \multicolumn{2}{|c|}{ Óleo de cozinha } & I/mês \\
\hline & & \multicolumn{2}{|c|}{ Tetrapak } & t/mês \\
\hline & & \multirow{5}{*}{ Outros } & & t/mês \\
\hline & & & & t/mês \\
\hline & & & & t/mês \\
\hline & & & & t/mês \\
\hline & & & & t/mês \\
\hline
\end{tabular}

